\title{
Virtuelle Auslandsentsendungen
}

\author{
Inaugural-Dissertation
}

zur Erlangung des akademischen Grades eines Doktors der Wirtschafts- und Sozialwissenschaften

(Dr. rer. pol.)

der Friedrich-Alexander-Universität Erlangen-Nürnberg

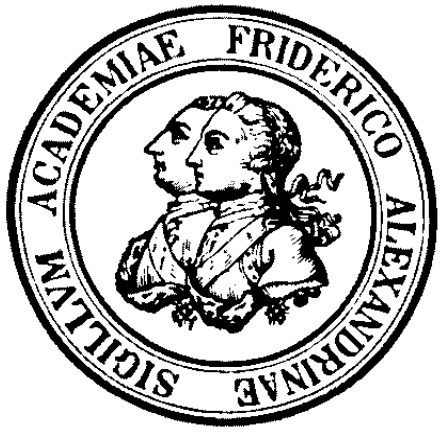

vorgelegt von Dipl.-Kffr. Katrin Schillo aus Nürnberg 
Erstreferent: Professor Dr. Dirk Holtbrügge

Zweitreferent: Professor Dr. Andreas Falke

Letzte Prüfung: 28. April 2009 


\section{Inhaltsverzeichnis}

Inhaltsverzeichnis $\quad$ iii

Abbildungsverzeichnis vii

Tabellenverzeichnis $\quad$ viii

\section{Kapitel 1 Problemstellung, Zielsetzung und Aufbau der Arbeit}

1.1 Problemstellung und Relevanz 2

1.2 Zielsetzung 5

1.3 Problemgegenstand 6

1.4 Aufbau der Arbeit 8

1.5 Kurzzusammenfassung der einzelnen Kapitel 12

Kapitel 2 Virtuelle Auslandsentsendungen. Konzeptionelle Grundlagen, Anwendungsbeispiele und Bewertung

2.1 Traditionelle Formen der Besetzung von Fach- und Führungspositionen im Ausland

2.2 Neue Formen der Stellenbesetzung 19

2.3 Merkmale virtueller Auslandsentsendungen 20

2.4 Beispiele virtueller Auslandsentsendungen $\quad 23$

2.5 Bewertung und Anwendungsvoraussetzungen virtueller

Auslandsentsendungen

Kapitel 3 Virtual Delegation Across Borders: A Knowledge-based Perspective

3.1 Problem and Objectives 30

3.2 Theory and Hypotheses: A Knowledge-based View of Virtual Assignments 32

3.2.1 Intensity of Knowledge Transfer and Use of Virtual Delegations 33

3.2.2 Direction of Knowledge Transfer and Use of Virtual Delegations 34

3.2.3 Mode of Knowledge Transfer and Use of Virtual Delegations 34

3.3 Methodology 36

3.3.1 Sample $\quad 36$

3.3.2 Measures 37

$\begin{array}{lll}\text { 3.3.2.1 Dependent Variables } & 37\end{array}$

$\begin{array}{lll}\text { 3.3.2.2 Independent Variables } & 38\end{array}$

$\begin{array}{lll}\text { 3.3.2.3 Control Variables } & 38\end{array}$

3.4 Results and Discussion 39

3.5 Contributions, Limitations and Implications for Future Studies 41 


\section{Kapitel 4 Remote Control of Foreign Subsidiaries.}

\section{A Transaction Cost Analysis of Virtual Expatriation}

4.1 Problem and Objectives

4.2 Theory and Hypotheses: A Transaction Cost Perspective of Virtual Expatriation

4.2.1 Asset Specificity, Uncertainty, and Frequency 50

4.2.2 Asset Specificity and the Use of Virtual Expatriates 51

4.2.3 Uncertainty and the Use of Virtual Expatriates 52

4.2.4 Frequency and the Use of Virtual Expatriates 53

4.3 Methodology $\quad 54$

$\begin{array}{lll}4.3 .1 & \text { Sample } & 54\end{array}$

4.3.2 Measures $\quad 55$

4.3.2.1 Dependent Variable $\quad 55$

4.3.2.2 Independent Variables $\quad 56$

$\begin{array}{lll}\text { 4.3.2.3 Control Variables } & 56\end{array}$

4.4 Results and Discussion $\quad 57$

4.5 Contributions, Limitations and Implications for Future Studies 59

Kapitel 5 Remote Services in Softwareunternehmungen. Das Beispiel SAP

5.1 Problemstellung, Zielsetzung und Aufbau des Beitrages 66

$\begin{array}{lll}5.2 & \text { Struktur des IT-Marktes } & 67\end{array}$

5.3 SAP und die Abteilung System Landscape Optimization 68

$\begin{array}{lll}\text { 5.3.1 Die Unternehmung SAP } & 68\end{array}$

5.3.2 Profil der Abteilung System Landscape Optimization $\quad 70$

$\begin{array}{lll}5.4 & \text { Das Projekt Marubeni } & 72\end{array}$

$\begin{array}{lll}5.4 .1 & \text { Kurzportrait } & 72\end{array}$

5.4.2 Konfiguration der Wertkettenaktivitäten 73

$\begin{array}{lll}\text { 5.4.2.1 Besondere Herausforderungen und Chancen } & 73\end{array}$

$\begin{array}{lll}\text { 5.4.2.2 Derzeitige Realisierung bei SAP } & 74\end{array}$

5.4.2.3 Zukünftige Bedeutung 75

$\begin{array}{lll}5.4 .3 & \text { Koordination } & 76\end{array}$

5.4.3.1 Koordinationsbedarf 76

5.4.3.2 Eingesetzte Koordinationsinstrumente 76

$\begin{array}{lll}\text { 5.4.3.2.1 Technische Hilfsmittel } & 76\end{array}$

$\begin{array}{lll}\text { 5.4.3.2.2 Unternehmungskultur } & 78\end{array}$

$\begin{array}{lll}\text { 5.4.3.2.3 Sicherheitsaspekte } & 79\end{array}$

$\begin{array}{lll}\text { 5.4.3.2.4 Qualitätssicherung } & 79\end{array}$ 
$\begin{array}{llr}\text { 5.4.4 Kundenintegration } & 80\end{array}$

$\begin{array}{lll}\text { 5.4.4.1 Rolle des Kunden } & 80\end{array}$

5.4.4.2 Beobachtbarkeit der Dienstleistungserstellung 81

5.4.4.3 Probleme bei der Kundenintegration 81

$\begin{array}{lll}\text { 5.4.4.4 Kundenbindung } & 82\end{array}$

$\begin{array}{lll}\text { 5.4.4.5 Erfolgsfaktoren auf Kundenseite } & 83\end{array}$

$\begin{array}{lll}\text { 5.4.4.6 Vertrauensbildende Maßnahmen } & 83\end{array}$

5.4.4.7 Akzeptanz von Remote Services $\quad 84$

$\begin{array}{lll}\text { 5.4.5 Personalmanagement } & 84\end{array}$

5.4.5.1 Besondere Herausforderungen und Chancen 84

5.4.5.2 Derzeitige Realisierung bei SAP 85

$\begin{array}{lll}\text { 5.4.5.2.1 Personalbedarfplanung und -deckung } & 85\end{array}$

$\begin{array}{lll}\text { 5.4.5.2.2 } & \text { Personalentwicklung } & 85\end{array}$

$\begin{array}{lll}\text { 5.4.5.2.3 } & \text { Personaleinsatz } & 87\end{array}$

$\begin{array}{lll}\text { 5.4.5.2.4 Personalführung } & 87\end{array}$

$\begin{array}{lll}\text { 5.4.5.2.5 Arbeitszufriedenheit } & 88\end{array}$

$\begin{array}{lll}5.5 & \text { Fazit und Ausblick } & 88\end{array}$

\section{Kapitel 6 Problemfelder virtueller Auslandsentsendungen.} Ergebnisse einer empirischen Studie

6.1 Problemstellung, Zielsetzung und Aufbau des Beitrages 92

6.2 Aufbau und Ablauf der empirischen Studie 92

6.3 Probleme virtueller Auslandsentsendungen 93

6.3.1 Kommunikation 96

6.3.1.1 Interkulturelle Kommunikation 96

$\begin{array}{lll}\text { 6.3.1.1.1 Kulturbedingte Interpretationsstörungen } & 97\end{array}$

$\begin{array}{ll}\text { 6.3.1.1.2 Mangelnde Sprachkenntnisse } & 98\end{array}$

6.3.1.1.3 Unterschiedliche Kontextorientierung 99

$\begin{array}{lr}\text { 6.3.1.2 Medial vermittelte Kommunikation } & 100\end{array}$

6.3.1.2.1 Beschränkungen medial vermittelter Kommunikation $\quad 100$

6.3.1.2.2 Medial vermittelte interkulturelle Kommunikation 103

$\begin{array}{ll}\text { 6.3.2 Unterschiede im Zeitverständnis } & 104\end{array}$

$\begin{array}{lll}\text { 6.3.2.1 Termine und Deadlines } & 104\end{array}$

$\begin{array}{lll}\text { 6.3.2.2 Zeithorizont } & 106\end{array}$

$\begin{array}{lll}6.3 .3 & \text { Vertrauen } & 107\end{array}$

$\begin{array}{lll}\text { 6.3.4 Führung auf Distanz } & 108\end{array}$

$\begin{array}{lll}\text { 6.3.4.1 Soziale Präsenz } & 108\end{array}$

$\begin{array}{ll}\text { 6.3.4.2 Kontrolle von Mitarbeitern } & 108\end{array}$

$\begin{array}{ll}\text { 6.3.4.3 Motivation von Mitarbeitern } & 109\end{array}$

$\begin{array}{ll}\text { 6.3.4.4 Mentoring von Mitarbeitern } & 109\end{array}$

6.4 Zusammenfassung und Implikationen 110 


\section{Kapitel 7 Intercultural Training Requirements for Virtual Assignments: Results of an Explorative Empirical Study}

7.1 Problem and Objectives

7.2 Virtual Assignments as a New Form of Filling Overseas Positions 117

$\begin{array}{lll}7.3 & \text { Intercultural Training } & 118\end{array}$

$\begin{array}{lll}7.4 & \text { Methodology } & 121\end{array}$

7.4.1 Case Study: Virtual Assignments at a Major German Software Company 122

7.4.1.1 Remote Services as Organizational Context 122

7.4.1.2 Communication and Service Delivery during the Project 123

$\begin{array}{lll}\text { 7.4.2 Requirements for Intercultural Training } & 125\end{array}$

7.5 Contributions, Limitations and Implications for Future Studies 130

\section{Kapitel 8 Zusammenfassung und Implikationen}

8.1 Zusammenfassung der Erkenntnisse 136

8.2 Implikationen für die Forschung 139

8.3 Implikationen für die Unternehmungspraxis 140 


\section{Abbildungsverzeichnis}

Abbildung 1-1: $\quad$ Methodischer Aufbau der Arbeit 11

Abbildung 2-1: $\quad$ Merkmale realer und virtueller Auslandsentsendungen 22

Abbildung 3-1: $\quad$ Research Model of our Study 36

Abbildung 4-1: $\quad$ Research Model 54

Abbildung 5-1: $\quad$ Marktanteile im Bereich Unternehmenssoftware im Jahr 2004

Abbildung 5-2: $\quad$ Organigramm der SAP AG im Jahre 2006

Abbildung 5-3: Wertkette der Abteilung SLO 71

Abbildung 6-1: $\quad$ Probleme virtueller Auslandsentsendungen (Häuftigkeiten) 94

Abbildung 6-2: $\quad$ Probleme virtueller Auslandsentsendungen (Bedeutung) 95

Abbildung 6-3: Problemfelder bei virtuellen Auslandsentsendungen 96

Abbildung 6-4: Zuordnung von Signifier zu Signified 97

Abbildung 7-1: $\quad$ Typology of Intercultural Training 119

Abbildung 7-2: $\quad$ Summary of research propositions 130 


\section{Tabellenverzeichnis}

Tabelle 2-1: Vor- und Nachteile von alternativen Formen der Besetzung von Fach- und Führungspositionen im Ausland

Tabelle 3-1: Geographical Distribution of the Sample 37

Tabelle 3-2: Means, Standard Deviations and Correlations 39

Tabelle 3-3: $\quad$ Regression Analysis on Use of Virtual Delegates 40

Tabelle 4-1: Geographical Distribution of the Sample 55

Tabelle 4-2: $\quad$ Means, Standard Deviations and Correlations 57

Tabelle 4-3: $\quad$ Regression Analysis $\quad 58$ 


\section{Kapitel 1 \\ Problemstellung, Zielsetzung und Aufbau der Arbeit}

\section{Gliederung}

1.1 Problemstellung und Relevanz

1.2 Zielsetzung

1.3 Problemgegenstand

1.4 Aufbau der Arbeit

1.5 Kurzzusammenfassung der einzelnen Kapitel 


\subsection{Problemstellung und Relevanz}

Die zunehmende Globalisierung der Märkte und der damit einhergehende grenzüberschreitende Wettbewerb, führen zu einem stetigen Innovations- und Kostendruck und stellen viele Unternehmungen vor neue Herausforderungen. Die drastischen Veränderungen der Märkte in den letzten Jahren konfrontieren vor allem international tätige Unternehmungen mit einer verschärften Konkurrenzsituation. Für Unternehmungen wird die Fähigkeit, international effizient zu agieren, zu einem unverzichtbaren Erfolgsfaktor und weckt das Bedürfnis, ihre Engagements im In- und Ausland aus einer globalen Perspektive zu sehen und einem gemeinsamen Ziel zu unterstellen (vgl. Holtbrügge, 2003).

Dieses Vorgehen wird in der Literatur auch als transnationale Strategie bezeichnet (vgl. Welge \& Holtbrügge, 2006). Dabei verfolgen Unternehmungen das Ziel gleichzeitig economies of scale, economies of scope sowie nationale Unterschiede auszunutzen (vgl. Ghoshal, 1987). Internationale Unternehmungen mit Tochtergesellschaften in verschiedenen Ländern dürfen dabei ihre in- und ausländischen Engagements nicht isoliert betrachten und an die Anforderungen der jeweiligen Märkte anpassen, sondern müssen eine Strategie verfolgen, die eine Ausschöpfung länderübergreifender Wettbewerbsvorteile ermöglicht. Ein bedeutendes Instrument zur Generierung dieser Wettbewerbsvorteile stellt die länderübergreifende Konfiguration der Wertaktivitäten dar (vgl. Welge \& Holtbrügge, 2006, S. 147 f.). Dabei stehen international tätigen Unternehmungen zwei idealtypische Gestaltungsalternativen zur Verfügung: Zum einen die vollständige Konzentration einer oder sämtlicher Wertaktivitäten an einem Standort und andererseits deren geographische Streuung über eine Vielzahl an Standorten weltweit. Die Vorteilhaftigkeit dieser Alternativen hängt insbesondere von der Stellung der jeweiligen Wertaktivität in der Wertkette sowie der relativen Bedeutung der dadurch erzielbaren economies of scale bzw. komparativen Kosten- und Koordinationsvorteile ab (vgl. Porter, 1989, S. 25 ff.).

Die länderübergreifende Konfiguration der Wertaktivitäten führt idealtypischerweise zu einer Unternehmung mit weltweit verteilten, stark spezialisierten und vernetzten Tochtergesellschaften. Dabei stellen die Tochtergesellschaften kein verkleinertes Abbild der Muttergesellschaft dar (vgl. Bartlett \& Ghoshal, 1986), sondern bilden ein Element eines transnationalen Wertschöpfungsnetzwerks (vgl. Welge \& Holtbrügge, 2006). Diese Form der Konfiguration führt aufgrund komplexer Liefer- und Leistungsverflechtungen innerhalb des weltweiten Wertschöpfungsnetzwerkes zu einem hohen Koordinationsaufwand, für welchen geeignete Instrumente gefunden werden müssen.

Zusammenfassend sehen sich international tätige Unternehmungen also verstärkt mit der Frage konfrontiert, wie sie ihre Engagements im In- und Ausland im Sinne einer globalen Zielsetzung leiten sollen. Insbesondere die effiziente Besetzung von Fach- und Führungspositionen in den ausländischen Tochtergesellschaften stellt dabei eine zentrale Herausforderung dar (vgl. Harvey et al., 2001; Harzing, 2001; Rosenzweig \& Nohria, 1994; Welge \& Holtbrügge, 2006, S. 223 ff.). 
Aufgrund der rasanten Weiterentwicklungen im Bereich der Informations- und Kommunikationstechnologie bieten sich Unternehmungen neben den klassischen Formen der Stellenbesetzung von Positionen im Ausland, nämlich der Entsendung von Stammhausmitarbeitern, der Beschäftigung von lokalen Mitarbeitern oder der Einsatz von Mitarbeitern aus Drittländern, neue Möglichkeiten. Eine dieser Möglichkeiten ist der Einsatz virtueller Auslandsentsandter. Dies kommt vor allem bei der Erbringung von ferngelenkten Dienstleistungen ${ }^{1}$, sogenannten Remote Services, zum Einsatz.

Während bei der klassischen Dienstleistung meist der Ort der Leistungserstellung mit der tatsächlichen Präsenz der Kunden zusammenfällt (Holtbrügge et al., 2004), wird im Rahmen von Remote Sevices die traditionelle Verbindung zwischen Dienstleistungsanbieter und Kunde zunehmend aufgehoben (Wünderlich et al., 2007). Dies hat weitreichende Folgen für die Organisationsgestaltung und den weltweiten Mitarbeitereinsatz, da Dienstleistungen im Rahmen von Remote Sevices zeitlich und räumlich losgelöst vom Kunden durchgeführt werden können.

Waren früher international tätige Dienstleistungsanbieter darauf angewiesen ihre Servicemitarbeiter am Kundenstandort bereitzustellen, sei es mittels erhöhter Reisetätigkeit der Mitarbeiter oder durch Aufbau eines regionalen Services-Standorts, bieten die neuen Informations- und Kommunikationstechnologien mittlerweile die Möglichkeit einen Großteil der anfallenden Tätigkeiten unter Einsatz von virtuellen Entsandten aus der Muttergesellschaft im Heimatland zu erledigen. Hierdurch können nicht nur Kosten eingespart, sondern Mitarbeiter weitaus flexibler eingesetzt werden, da sie nicht mehr von einem Kundenstandort zum anderen reisen müssen. Dies kann dazu führen, dass ein Mitarbeiter an einem Tag mit Kunden in Asien, Europa und Amerika zusammenarbeitet und kommuniziert. Somit werden beim virtuellen Auslandseinsatz Fach- und Führungskräfte der Muttergesellschaft nicht mehr ins Ausland entsandt, sondern verbleiben im Heimatland und interagieren von hier mit Hilfe von modernen Informations- und Kommunikationsmedien mit Mitarbeitern, Kunden, Lieferanten und Kooperationspartnern im Ausland.

Somit lässt sich die theoretische Relevanz der Arbeit mit der Neuartigkeit des Problemgegenstands begründen. Die virtuelle Auslandsentsendung stellt ein relativ neues und bislang noch wenig untersuchtes Phänomen des Personalmanagements dar. Die Literatur zu diesem Thema beschränkt sich vorwiegend auf eine Beschreibung des Phänomens und dessen mögliche Einsatzgebiete (vgl. Iten, 2001; Welch et al., 2003). Ebenso wurden bislang in der Literatur Probleme von virtuellen Auslandsentsendungen nur abgeleitet, ob diese in der Unternehmungspraxis tatsächlich relevant sind und welche Bedeutung sie haben, wurde noch nicht empirisch überprüft.

1 Die vorliegende Arbeit ist im Rahmen des Forschungsprojektes „EXFED - Export ferngelenkter Dienstleistungen“ (FKZ 01HQ0553) entstanden. Das Projekt befasst sich mit den Herausforderungen des Exports ferngelenkter Dienstleistungen und hat die Entwicklung eines ganzheitliches, theoretisch und empirisch fundiertes Konzept für das Management von Remote Services zum Ziel. Einen der drei zentralen Themenschwerpunkte stellt dabei das Personalmanagement und insbesondere der Einsatz von virtuellen Auslandsentsendungen dar. 
Darüber hinaus beschränken sich theoretisch fundierte Analysen zu Auslandsentsendungen sowie deren empirische Überprüfung bislang ausschließlich auf den Einsatz traditioneller Auslandsentsendungen (Tan \& Mahoney, 2006). Empirische Untersuchungen zum Einsatz neuer Formen, wie der virtuellen Auslandsentsendung, fehlen gänzlich.

So zeigen etwa Studien zu traditionellen Auslandentsendungen, dass der Erfolg von Entsendungen maßgeblich von der Vorbereitung abhängt (vgl. Deshpande \& Viswesvaran, 1992; Blake et al., 1996; Goldstein \& Smith, 1999). Bei virtuellen Entsandten wird dieser Aspekt häufig unterschätzt, da die Mitarbeiter weiterhin im Heimatland verbleiben. So finden sich in der Literatur bislang auch keine Anhaltspunkte zu Trainingsanforderung für die Vorbereitung virtueller Auslandsentsendungen.

Darüber hinaus existieren in der Literatur zu virtuellen Auslandsentsendungen bislang keine Erkenntnisse zu deren Einsatz im Bereich der Dienstleistungserbringung. Im Dienstleistungssektor haben sich aufgrund technologischer Entwicklungen neue Möglichkeiten, wie ferngelenkte Dienstleistungen (sogenannte Remote Services), ergeben. Im Rahmen dieser scheint ein Einsatz virtueller Auslandsentsandter sinnvoll, eine fundierte Analyse existiert jedoch bisher nicht.

Zusammenfassend kann die vorliegende Arbeit somit auf wissenschaftlicher und theoretischer Ebene einen erheblichen Beitrag leisten, da in der existierenden Literatur kaum fundierte Erkenntnisse zu virtuellen Entsendungen existieren.

Neben diesen wissenschaftlichen Aspekten besitzt die Arbeit jedoch auch eine erhebliche praktische Relevanz. Wie oben erläutert, sind virtuelle Auslandsentsendungen ein noch neues Instrument im Personalmanagement, welches bislang bei international tätigen Unternehmungen noch selten zum Einsatz kommt. Aufgrund der zahlreichen Vorteile gegenüber traditionellen Auslandsentsendungen könnte ihr Einsatz für viele international tätige Unternehmungen sinnvoll sein. So werden beispielsweise die anfallenden Kosten im Vergleich zu klassischen Auslandentsendungen stark reduziert. Diese Differenz zwischen Einsatzhäufigkeit und Einsatzvorteilen könnte auch dadurch erklärt werden, dass die Möglichkeit einer Entsendung in virtueller Form vielen Unternehmungen bisher nicht bekannt ist. Somit kann bereits die intensive Beschäftigung und Diskussion mit der Thematik durch Information einen erheblichen Beitrag für die Praxis leisten.

Um die Vor- und Nachteile des Einsatzes von virtuellen Auslandsentsendungen in verschiedenen Kontexten gegeneinander abwägen zu können, bietet eine systematische Analyse fundiert abgeleiteter Determinanten des Einsatzes Entscheidungsträgern im Vorfeld eine Hilfestellung. Auch hier setzt die vorliegende Arbeit in Kapitel drei aus Knowledge-based-Sicht und Kapitel vier aus einer Transationskostentheoretischen Perspektive an und kann somit einen deutlichen Beitrag für die Praxis leisten. Managern kann so eine Entscheidungshilfe zum Einsatz virtueller Entsandter geboten werden, da die Analysen zeigen, unter welchen Umständen virtuelle Auslandsentsandte zum Wissenstransfer oder als Kontrollinstrument für ausländische Tochter- 
gesellschaften genutzt werden.

Allerdings sind mit dem Einsatz von virtuellen Auslandsentsendungen auch zahlreiche Herausforderungen verbunden. Diese sind jedoch bisher nicht systematisch untersucht worden. Auch hier leistet die vorliegende Arbeit durch eine systematische Untersuchung der Problemfelder virtueller Entsendungen einen Beitrag. Dies erfolgt in Kapitel fünf in Form einer Fallstudienanalyse, in Kapitel sechs im Rahmen einer quantitativen Analyse. Praktiker können diese Erkenntnisse nutzen, um die Einsatzmöglichkeiten virtueller Entsendungen für spezifische Aufgaben im Unternehmen zu prüfen. Darüber hinaus leistet Kapital sieben einen Beitrag, wie diese Probleme durch ein spezifisches, aus den Problemfelder abgeleitetes, kulturelles Training für virtuelle Entsandte gelöst werden können.

\section{$1.2 \quad$ Zielsetzung}

Insgesamt ist es die Zielsetzung dieser Arbeit, sich mit theoretisch und praktisch relevanten Aspekten der virtuellen Entsendung zu befassen. Der wissenschaftliche und praktische Erkenntnisfortschritt im Bereich der virtuellen Auslandsentsendungen sowie die Entwicklung von Entscheidungshilfen für Manager bilden das Hauptziel dieser Arbeit. Im Folgenden werden die dazu notwendigen Teilziele, die mit den einzelnen Kapiteln der Arbeit verbunden sind, genauer dargestellt.

Zunächst steht das Ziel im Vordergrund, ein einheitliches und grundlegendes Verständnis von virtuellen Auslandsentsendungen zu schaffen. Hierbei wird besonderer Wert auf die Herausstellung der Merkmale, Vor- und Nachteile sowie Anwendungsvoraussetzungen gelegt. Dafür wird in Kapitel zwei zunächst der Begriff der virtuellen Entsendung definiert und in den Kontext traditioneller Entsendungen eingeordnet.

Ein weiteres Ziel liegt darin, die Nutzung virtueller Entsendungen für unterschiedliche Zwecke wissenschaftlich fundiert zu erklären. Dafür werden in Kapitel drei und vier unter Rückgriff auf zwei unterschiedliche Theorien Determinanten virtueller Entsendungen abgeleitet und empirisch überprüft. In Kapitel drei wird hierfür der Knowledge-Based View genutzt, in Kapitel vier die Transaktionskostentheorie. Spezifisch wird das Ziel verfolgt zu analysieren, unter welchen Umständen sie virtuelle Auslandsentsandte zum Wissenstransfer oder als Kontrollinstrument für ausländische Tochtergesellschaften eingesetzt werden.

Drittes Ziel der Arbeit ist es, einen strukturierten Überblick über Probleme des Einsatzes von virtuellen Entsendungen zu bekommen. Hierzu werden zunächst auf Basis einer qualitativen Analyse die Auswirkungen des virtuellen Auslandseinsatzes im Rahmen von Remote Services auf die Managementinstrumente identifiziert. In einem weiteren Schritt wird anhand einer quantitativen Studie die Relevanz von Problemen in der Unternehmungspraxis überprüft.

In der Literatur wird die Bedeutung einer systematischen Vorbereitung im Rahmen traditio- 
neller Auslandsentsendungen in Form von interkulturellen Trainings betont. Jedoch gibt es in der bestehenden Literatur keinerlei Anhaltspunkte zu interkulturellen Trainings für virtuelle Entsandte. Deshalb soll es ein letztes und abschließendes Ziel dieser Arbeit sein, konkrete Anforderungen für die Entwicklung von interkulturellen Trainings für den virtuellen Auslandseinsatz abzuleiten und erste Ansätze für eine mögliche Ausgestaltung der Trainings zuliefern. Im Besonderen soll dabei auf die Trainingsinhalte, Methoden und den Kreis der Teilnehmer eingegangen werden.

\subsection{Problemgegenstand}

Nachdem im vorangegangenen Abschnitt die Relevanz der Arbeit abgeleitet und die Zielsetzung dargestellt wurde, folgt in diesem Abschnitt eine Beschreibung des Untersuchungsgegenstandes der virtuellen Auslandsentsendung. Hierbei wird zunächst auf die klassische Auslandsentsendung eingegangen um darauf aufbauend die Entwicklungen hin zur virtuellen Auslandsentsendung aufzuzeigen.

Wie schon in der Problemstellung dargestellt, sieht sich das Management international tätiger Unternehmungen mit der Frage konfrontiert, wie die internationalen Engagements geleiten werden sollen. Die zentrale Herausforderung im Personalmanagement stellt dabei die effiziente Besetzung von Fach- und Führungspositionen im Ausland dar (vgl. Harvey et al., 2001; Harzing, 2001; Rosenzweig \& Nohria, 1994; Welge \& Holtbrügge, 2006, S. 211 ff.). Traditionell stehen hierzu drei Alternativen zur Verfügung: Die Entsendung von Stammhausmitarbeitern, die Beschäftigung von lokalen Mitarbeitern und der Einsatz von Mitarbeitern aus Drittländern.

Den größten Vorteil Stammhausdelegierter bildet ihre Kenntnis über die Muttergesellschaft. Dies vereinfacht die Umsetzung einer weltweit einheitlichen Unternehmungspolitik ebenso, wie die Kommunikation und Koordination zwischen Tochter- und Muttergesellschaft und den Transfer von Technologie- und Management-Know-how in die ausländischen Tochtergesellschaften. Nachteilig wirken sich allerdings die hohen Kosten der Entsendung aus. Diese entstehen durch die Vorbereitung, den Auslandsaufenthalt selbst und die Wiedereingliederung. Ein weiteres Problem kann die Anpassung der Entsandten und ihrer Familien an die Bedingungen im Gastland darstellen.

Lokale Mitarbeiter verursachen dagegen zumeist weitaus geringere Personalkosten und zusätzlich entfallen die Anpassungsprobleme. Der Einsatz lokaler Mitarbeiter erschwert jedoch die Koordination und Kommunikation zwischen Mutter- und Tochtergesellschaft und den Knowhow-Transfer innerhalb der Unternehmung. Desweiteren ist unklar, inwieweit sich der lokale Manager an die Umsetzung der Unternehmungspolitik hält.

Die dritte Alternative, der Einsatz von Drittlandangehörigen, beinhaltet vor allem ein größeres Potenzial an qualifizierten Bewerbern und ermöglicht eine flexiblere Personalbeschaffung. Nachteile dieser Form der Stellenbesetzung sind neben den hohen Personalkosten, der wie bei 
lokalen Mitarbeitern bestehende Koordinationsaufwand. Zudem ist auch hier die Umsetzung einer weltweit einheitlichen Unternehmungspolitik unsicher.

Im Hinblick auf die Steuerung von ausländischen Tochtergesellschaften erscheint der Einsatz von Stammhausdelegierten am sinnvollsten. Im Zusammenhang mit dieser Alternative zeigen sich neben den hohen Kosten weitere Schwierigkeiten und Herausforderungen. So belegen Studien, dass international tätige Unternehmungen zunehmen mit einer ablehnenden Haltung ihres Personals gegenüber Auslandsentsendungen zu kämpfen haben (Caligiuri \& Cascio, 1998; Scullion, 1994; Stroh \& Caligiuri, 1998). Eine wichtige Ursache stellt dabei die dual-careerProblematik dar, bei der durch den Auslandsaufenthalt die Karriere des Partners gefährdet ist (vgl. Harvey, 1997). Um diese Probleme bei der Stellenbesetzung zu überwinden, werden Alternativen diskutiert, die mit einer deutlichen Reduktion der Entsendungsdauer verbunden sind. Hierbei lassen sich drei verschiedene Formen unterscheiden (vgl. Harris et al., 2005; Mayerhofer et al., 2004a): Kurzfristige Auslandsentsendungen, mit einer Entsendungsdauer von unter einem Jahr, internationales Pendeln, wobei der Mitarbeiter im ein bis zwei Wochenrhythmus zwischen seinen zwei Tätigkeits- und Wohnorten pendelt, und Vielflieger-Entsendungen, mit häufigen Dienstreisen ins Ausland.

Alle drei Formen reduzieren die Abwesenheit im Vergleich zur traditionellen Entsendung. Somit wird eine Übersiedlung der Lebenspartner bzw. Familien nicht mehr notwendig, wodurch Kosten eingespart werden. Ebenso wird die Dual-Career-Problematik reduziert. Des Weiteren wird aufgrund der kürzeren Abwesenheit vom Heimatland die Reintegration erleichtert, bzw. bleibt der Mitarbeiter in der Muttergesellschaft integriert. Diese Vorteile stehen allerdings dem Nachteil der hohen Reisetätigkeit und Abwesenheit vom Heimatort gegenüber, was insbesondere bei internationalen Pendlern und Vielfliegern zu einer hohen physischen und psychischen Belastung führt (vgl. Mayerhofer et al., 2004b). Zur Lösung dieser Problematik nutzen einige Unternehmungen heute so genannte virtuelle Auslandsentsendungen.

Ein virtueller Auslandsentstandter ist "an employee [who] does not relocate to a host location, but has international responsibilities for a part of the oragnization in another country which they manage from the home country" (PricewaterhouseCoopers, 2001, S. 31).

Bei einer virtuellen Entsendung hält sich der Mitarbeiter physisch im Heimatland auf, arbeitet aber vor allem mit Personen in anderen Ländern zusammen. Dadurch besteht nicht nur eine geographische Trennung von Arbeits- und Wohnort des Entsandten im Heimatland und den Interaktionspartnern im Gastland über Ländergrenzen hinweg, sondern ebenso eine kulturelle und sprachliche Trennung zwischen den Interaktionspartnern. Kennzeichnend für die virtuellen Auslandsentsendungen ist weiterhin die hauptsächlich über elektronische Informationsund Kommunikationstechnologien verlaufende Interaktion. Darüber hinaus sind diese durch ein Weisungsrecht des virtuellen Auslandsentsandten gegenüber seinen Mitarbeitern im Ausland sowie ein Entscheidungsrecht gegenüber Kunden, Lieferanten oder Kooperationspartnern gekennzeichnet. 
Die Vorteile virtueller Auslandsentsendungen gegenüber traditionellen Formen der Stellenbesetzung im Ausland bestehen vor allem in der Reduzierung von Reisezeiten und -kosten sowie in der Flexibilisierung des Personaleinsatzes. Virtuelle Entsandte können zudem ihr gewohntes Lebensumfeld beibehalten, wodurch familiäre und soziale Probleme reduziert werden. Diesen Vorteilen stehen jedoch zahlreiche Herausforderungen gegenüber, die sich insbesondere durch die elektronisch vermittelte Kommunikation über Landes-, Kultur- und Sprachgrenzen ergeben (vgl. Holtbrügge \& Schillo, 2006; Iten, 2001; Welch et al., 2003).

\subsection{Aufbau der Arbeit}

Im folgenden Abschnitt wird der Aufbau der Arbeit erläutert, hierbei sollen vor allem die $\mathrm{Zu}-$ sammenhänge zwischen den einzelnen Beiträgen erläutert werden.

Im zweiten Kapitel wird zunächst das Phänomen der virtuellen Auslandsentsendung genauer beleuchtet. Ausgehend von den traditionellen Formen der Stellenbesetzung in Auslandsniederlassungen, nämlich dem Einsatz von Stammhausdelegierten, lokalen Mitarbeitern und Drittlandangehörigen, wird dargestellt, welche neuen Formen der Stellenbesetzung sich bieten. Hierbei steht die virtuelle Auslandsentsendung im Vordergrund. Es werden die Merkmale virtueller Auslandsentsendungen und Beispiele aus der Praxis beschrieben und bewertet sowie Anwendungsvoraussetzungen diskutiert. Der Beitrag dient dazu, ein allgemeines Verständnis der virtuellen Auslandsentsendung zu vermitteln und eine Grundlage für die folgen Beiträge zu liefern.

In der Literatur zur traditionellen Auslandsentsendung werden vornehmlich sechs Ziel genannt, die mit einer Entsendung verfolgt werden, dies sind: 1) Kompensation fehlender lokaler Fachund Führungskräfte, 2) Übertragungen von Management-, Produkt- und Verfahrens-Knowhow, 3) Gewährleistung effizienter Informations- und Kommunikationsstrukturen, 4) Steuerung und Kontrolle ausländischer Tochtergesellschaften, 5) Personal- und Organisationsentwicklung sowie 6) Schaffung einer länderübergreifenden Organisationskultur (vgl. Welge \& Holtbrügge, 2006, S. 225 f.). Als Hauptmotive für den Einsatz von Auslandsentsandten werden vor allem der Wissenstransfers innerhalb der Unternehmung (vgl. Bonache \& Brewster, 2001; Downes \& Thomas, 2000; Minbaeva \& Michailova, 2004; Tsang, 1999) sowie die Kontrolle der Auslandsniederlassungen (vgl. Doz \& Prahalad, 1986, 1988; Edström \& Galbraith, 1977) angesehen. Ausgehend von diesen Schwerpunkten des traditionellen Auslandseinsatzes werden für den folgenden Abschnitt der Arbeit theoretische Erklärungsansätze herangezogen, um den Einsatz von virtuellen Auslandsentsandten in Unternehmungen im Bezug auf den Wissenstransfer und die Kontrolle von ausländischen Tochtergesellschaften zu analysieren.

Bartlett \& Ghoshal (1987, S. 37) stellen fest, Wissensmanagement ist ,the ability to learn - to transfer knowledge and expertise from one part of the organization to others worldwide - [this] became more important in building durable competitive advantage." Um den Einsatz virtueller 
Auslandsentsandter als Instrument des Wissenstransfers zu untersuchen, dient im dritten Kapitel der Knowledge-based View als Analyserahmen. Auf dessen Basis werden Hypothesen zur Intensität, Richtung und Art des Wissenstransfers zwischen Auslandsniederlassung [/ausländischer Tochtergesellschaft] und Muttergesellschaft und ihr Einfluss auf den Einsatz von virtuellen Auslandsentsandten abgeleitet. Anhand einer Studie in den BRICS-Staaten (Brasilien, Russland, Indien, China und Südafrika) werden die aufgestellten Hypothesen empirisch überprüft. Um den Einsatz von virtuellen Auslandsentsandten als Kontrollinstrument für ausländische Tochtergesellschaften zu untersuchen, wird in Kapitel vier ein Ansatz aus der neuen Institutionenökonomie genutzt, die Transaktionskostentheorie. Diese dient in der betriebswirtschaftlichen Forschung mittlerweile als Erklärungsgrundlage für „vielfältige unternehmensführungs-, management- bzw. organisationsrelevante Gestaltungsfragen“ (Wolf, 2008, S. 351). Neben der Frage Eigenfertigung oder Fremdbezug, werden vor allem Fragestellungen zur Kontrolle, beispielsweise bei Internationalen Joint Ventures oder Auslandsniederlassungen, mit Hilfe der Transaktionskostentheorie analysiert (vgl. Cleeve, 1997; Erramilli \& Rao, 1993; Gatignon \& Anderson, 1988; Geringer \& Herbert, 1989; Hennart, 1988; Tsang, 2000). Die Transaktionskostentheorie scheint einen geeigneten Rahmen für die Analyse der Verwendung virtueller Auslandsentsandter als Kontrollinstrument zu bilden, da sie die Form des institutionellen Arrangements (virtuelle Auslandsentsendung) unter Einfluss verschiedener Situationsvariablen (Spezifität, Unsicherheit und Häufigkeit) untersucht. Zur Überprüfung der Hypothesen im Rahmen einer empirische Studie werden Daten von 172 Tochtergesellschaften in den BRICS-Staaten herangezogen.

Im Anschluss an die theoriebasierte Betrachtung des Phänomens der virtuellen Auslandsentsendung widmet sich der nächste Teil der Arbeit, der Analyse von Seiten der Unternehmungspraxis. Hierzu wird mit Hilfe qualitativer und quantitativer Analysemethoden ein Anwendungsbeispiel gegeben sowie Problemfelder identifiziert und daraus Implikationen abgeleitet. Dem anschließenden Kapitel, dienen die Elemente der gewonnen Erkenntnisse als Basis zur Ableitung von Trainingsanforderungen für virtuelle Auslandsentsandte.

Kapitel fünf bildet die Darstellung eines Anwendungsbeispieles für den Einsatz virtueller Auslandsentsendungen im Rahmen von Remote Services bei der SAP AG. Die Grundlage der Analyse bildet ein Projekt der Abteilung SLO (System Landscape Optimization) bei der japanischen Warenhauskette Marubeni. Mit Hilfe einer Fallstudie, basierend auf 16 qualitativen Interviews mit Mitarbeitern von SAP in Deutschland und Japan sowie beim Kunden Marubeni, werden die Herausforderungen aufgezeigt, die sich beim Einsatz von virtuellen Entsandten ergeben und welche Auswirkungen dies neben dem Personalmanagement, auch auf die weiteren Managementinstrumente Konfiguration, Koordination und Kundenintegration haben.

Die Analyse der Problemfelder virtueller Auslandsentsendungen in Kapitel sechs geht der Frage nach, welche Relevanz die in der Literatur beschriebenen Probleme in der Unternehmungspraxis haben. Hierzu werden zunächst Probleme von virtuellen Auslandsentsendungen aus 
theoretischen und empirischen Studien ermitteltet (vgl. Gibson \& Manuel, 2003; Hertel et al., 2005; Holtbrügge \& Schilo, 2006; Kayworth \& Leidner, 2000; Welch et al., 2003) und in einem Fragenkatalog zusammengefasst. Dieser Fragenkatalog bildet die Basis für eine online Umfrage unter aktuellen oder ehemaligen virtuellen Entsandten. Sie sollen anhand ihrer Erfahrungen beurteilen, welche Bedeutung die genannten Probleme in der Unternehmungspraxis haben und wie häufig diese auftreten. Die so identifizierten relevanten Probleme lassen sich in die Bereiche Kommunikation, Führung auf Distanz, Unterschiede im Zeitverständnis und Vertrauen einteilen und werden ausführlich diskutiert.

In den beiden vorangegangenen Studien aus der Unternehmungspraxis hat sich gezeigt, dass der Einsatz von virtuellen Auslandsentsandten nicht nur Vorteile mit sich bringt, sondern auch Probleme birgt. Dabei stellt sich heraus, dass die Probleme und Missverständnisse im Rahmen der virtuellen Auslandsentsendung häufig auf einen Mangel an direkter persönlicher Kommunikation zurückzuführen sind und diese zusätzlich durch die kulturellen Unterschiede verstärkt werden. Studien zu traditionellen Auslandsentsendungen verdeutlichen, dass der Erfolg einer Auslandsentsendung maßgeblich von der Vorbereitung, in Form von interkulturellen Trainings, abhängig ist (vgl. Blake et al., 1996; Deshpande \& Viewesvaran, 1992; Goldstein \& Smith., 1999). Dies erscheint auch für virtuelle Entsendungen eine geeignete Maßnahme, um den identifizierten Problemen entgegenzuwirken. Allerdings lassen sich in der Literatur noch keine Studien zu den Trainingsanforderungen für virtuelle Entsandte finden.

Mit der Ableitung von spezifischen interkulturellen Trainingsanforderungen im Rahmen von virtuellen Auslandsentsendungen beschäftigt sich das siebte Kapitel. Es wird ein exploratives Forschungsdesigns gewählt, wodurch ausgehend von den relevanten Problemen in der Praxis, der Einstieg in die Fragestellung ermöglicht werden soll. So wird auf Basis einer Fallstudie der Nutzen interkultureller Trainings für virtuelle Entsandte diskutiert und analysiert. Im Mittelpunkt stehen dabei die Anforderungen an die Trainingsinhalte und -methoden sowie an den Kreis der Teilnehmer. Die abgeleiteten „Propositions“ können als Basis für weitere Studien verwendet werden.

Im achten Kapitel der Arbeit werden abschließend die gewonnen Erkenntnisse zusammengefasst und Implikationen für Forschung und Praxis abgeleitet.

Abbildung 1-1 stellt den Aufbau der Arbeit nochmals graphisch dar. 


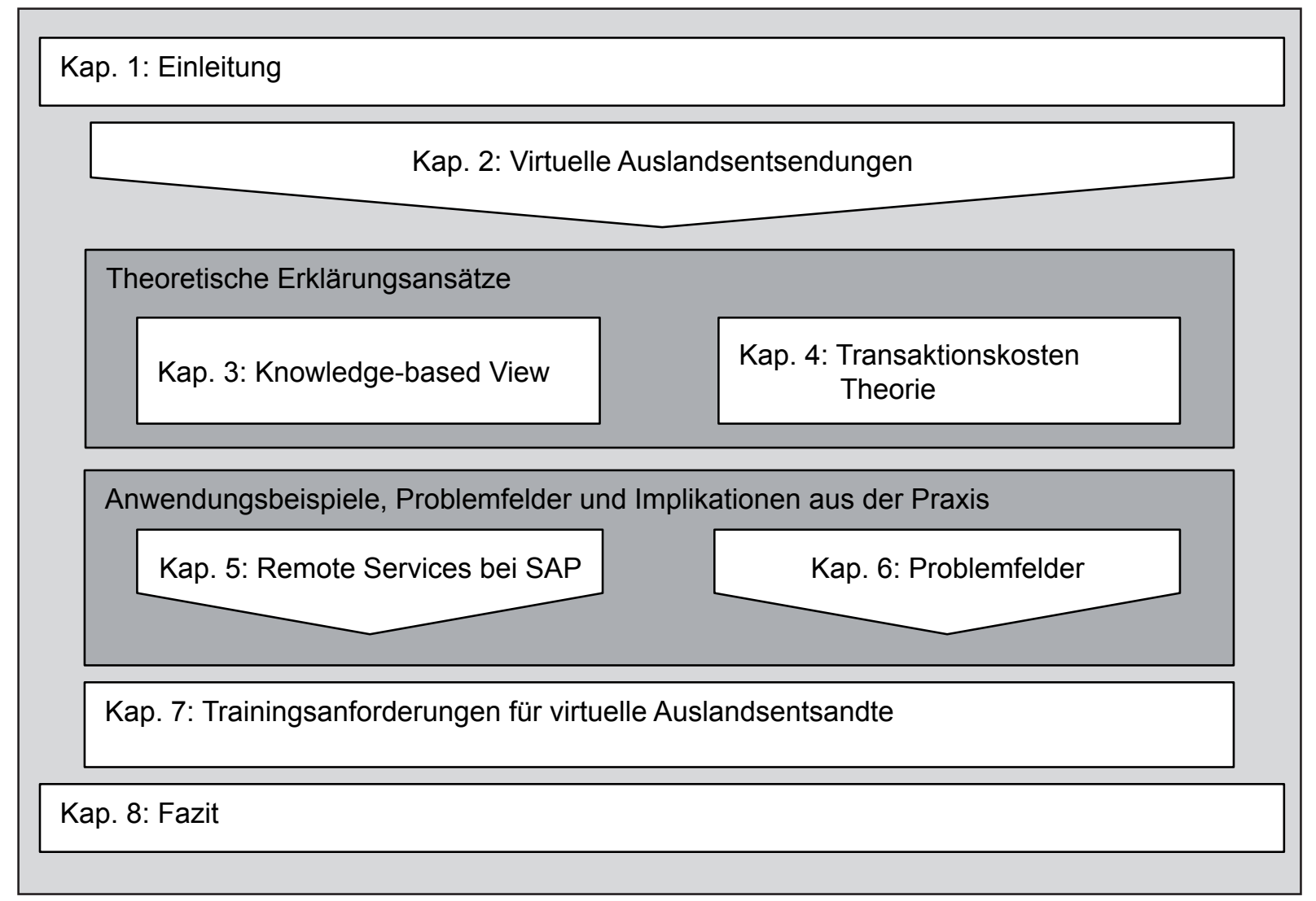

Abbildung 1-1: Methodischer Aufbau der Arbeit 


\subsection{Kurzzusammenfassung der einzelnen Kapitel}

\section{Kapitel 1: Einleitung}

Das erste Kapitel der Arbeit bietet neben Problemstellung und begrifflicher Abgrenzung, einen Überblick der einzelnen Beiträge und ihrer Zusammenhänge.

\section{Kapitel 2: Virtuelle Auslandsentsendungen - Konzeptionelle Grundlagen, Anwendungs- beispiele und Bewertung}

Das zweite Kapitel dient dazu, ein allgemeines Verständnis der virtuellen Auslandsentsendung zu vermittelt. Das Kapitel basiert auf zwei Beiträgen, die in ähnlicher Form in der Zeitschrift Wirtschaftswissenschaftliches Studium (WiSt), 35. Jg., Nr. 6, S. 320-324, 2006, und im Sammelband Remote Services. Neue Formen der Internationalisierung von Dienstleistungen, hrsg. v. D. Holtbrügge, H. Holzmüller \& F. v. Wangenheim. Wiesbaden: Deutscher UniversitätsVerlag, 2007, S. 27-37, veröffentlicht wurden. ${ }^{2}$

\section{Kapitel 3: Virtual Assignments - A Knowledge-based Perspective}

Im dritten Kapitel wird der Knowledge-based View als Erklärungsansatz gewählt, um die Verwendung von virtuellen Auslandsentsendungen zum Wissenstransfer in Unternehmungen zu analysieren. Anhand einer Studie in den BRICS-Staaten werden die aufgestellten Hypothesen empirisch überprüft. Eine erste Version des Beitrags wurde auf der 33. European International Business Academy (EIBA) Annual Conference: International Business, Local Development and Science-Technology Relationships in Catania (Italien) im Dezember 2007 präsentiert. Eine überarbeitete Version befindet sich im Begutachtungsprozess des European Management Jour$n a .^{3}$

\section{Kapitel 4: Remote Control of Foreign Subsidiaries - A Transaction Cost Analysis of Vir- tual Expatriation}

Mit Hilfe der Transaktionskosten-Theorie wird im vierten Kapitel der Einsatz von virtuellen Auslandsentsendungen als Kontrollinstrument ausländischer Tochtergesellschaften untersucht. Eine empirische Studie von 172 Tochtergesellschaften aus den BRICS-Staaten liefert die Datenbasis zur Überprüfung der Hypothesen. Der Beitrag befindet sich im Begutachtungsprozess des International Journal of Human Resource Management. ${ }^{4}$

2 Zusammen mit Dirk Holtbrügge.

3 Zusammen mit Dirk Holtbrügge.

4 Zusammen mit Dirk Holtbrügge. 


\section{Kapitel 5: Remote Services in Softwareunternehmungen. Das Beispiel SAP.}

Im Anschluss an die theoretischen Erklärungsansätze, folgt in Kapitel fünf die Darstellung eines Anwendungsbeispieles für den Einsatz virtueller Auslandsentsendungen im Rahmen von Remote Services bei der SAP AG. Hierbei werden mit Hilfe einer Fallstudie die Herausforderungen aufgezeigt, die sich beim Einsatz von virtuellen Entsandten ergeben und welche Auswirkungen dies neben dem Personalmanagement, auch auf die weiteren Managementinstrumente Konfiguration, Koordination und Kundenintegration haben. Der Beitrag wurde im Sammelband Remote Services. Neue Formen der Internationalisierung von Dienstleistungen, hrsg. v. D. Holtbrügge, H. Holzmüller \& F. v. Wangenheim. Wiesbaden: Deutscher UniversitätsVerlag, 2007, S. 141-167, veröffentlicht. ${ }^{5}$

\section{Kapitel 6: Problemfelder virtueller Auslandsentsendungen. Ergebnisse einer empirischen Studie.}

Die Analyse der Problemfelder virtueller Auslandsentsendungen in Kapitel sechs geht der Frage nach, welche Relevanz die in der Literatur beschriebenen Probleme in der Unternehmungspraxis haben. Der Beitrag wurde im Sammelband Remote Services. Neue Formen der Internationalisierung von Dienstleistungen, hrsg. v. D. Holtbrügge, H. Holzmüller \& F. v. Wangenheim. Wiesbaden: Deutscher Universitäts-Verlag, 2007, S. 41-64, veröffentlicht. ${ }^{6}$

\section{Kapitel 7: Intercultural Training Requirements for Virtual Assignments: Results of an Explorative Empirical Study.}

Ausgehend von den Herausforderungen und Problemfeldern beim Einsatz von virtuellen Auslandsentsandten werden im siebten Kapitel Anforderungen für interkulturelle Trainings zur Vorbereitung virtueller Auslandsentsander abgeleitet. Eine frühere Version des Beitrag wurde zunächst auf der 3. International Conference on Intercultural Communication Competence: Learning, Teaching and Research in a Borderless World, in Ahmedabad (Indien) im Oktober 2006 präsentiert und im dazugehörigen Tagungsband veröffentlicht (Learning, Teaching and Research in a Borderless World, hrsg. v. S. Manikutty. Bangalore et al.: Macmillan, 2007, S. 53-73). Eine überarbeitete Version des Beitrags wurde in der Zeitschrift Human Resource Development International, Vol. 11, 3, 2008, S. 271-286, abgedruckt. ${ }^{7}$

\section{Kapitel 8: Fazit}

Das achte und letzte Kapitel der Arbeit fasst die vorangegangenen Erkenntnisse zusammen und liefert einen abschließenden Ausblick.

$5 \quad$ Zusammen mit Dirk Holtbrügge, Annette Ohr und Marcus Wagner.

6 Zusammen mit Dirk Holtbrügge und Daniel Grundgreif.

$7 \quad$ Zusammen mit Dirk Holtbrügge. 


\section{Literaturverzeichnis}

Bartlett, C.A. \& Ghoshal, S. (1986): Managing Across Borders. A Transnational Solution, London.

Blake, J.M., Heslin, R. \& Curtis, S. (1996): Measuring Impacts of Cross-cultural Training, in: Landis, D. \& Baghat, R. (eds.): Handbook of Intercultural Training, 2nd ed., Thousand Oak: Sage Publications, p. 165-182.

Caligiuri, P. \& Cascio, W.F. (1998) Can we send her there? Maximizing the success of Western women on global assignments, in: Journal of World Business, 33. Jg., 4, S. 392-416.

Cleeve, E. (1997): The Motives for Joint Ventures: A Transaction Costs Analysis of Japanese MNEs in the UK, in: Scottish Journal of Political Economy, Vol. 44, 1, p. 31-43.

Delios, A. \& Björkman, I. (2000): Expatriate Staffing in Foreign Subsidiaries of Japanese Multinational Corporations in the PRC and the United States, in: International Journal of Human Resource Management, Vol. 11, 2, p. 278-293.

Deshpande, S.P. \& Viswesvaran, C. (1992): Is Cross-cultural Training of Expatriate Managers Effective: A Meta Analysis, in: International Journal of Intercultural Relations, Vol. 16, 3, p. 295-310.

Erramilli, M.K. \& Rao, C.P. (1993): Service Firms' International Entry-mode Choice: A Modified Transaction-cost Analysis Approach, in: Journal of Marketing, Vol. 57, 3, p. 19-38.

Gatignon, H. \& Anderson, A. (1988): Multinational Corporation's Control over Subsidiaries, in: Journal of Law, Economics, and Organization, Vol. 4, 2, p. 305-336.

Geringer, M.J. \& Hebert, L. (1989): Control and Performance of International Joint Ventures, in: Journal of International Business Studies, Vol. 20, 2, p. 235-254.

Ghoshal, S. (1987): Global Strategy. An organizational Framework, in: Straegic Management Journal, 8. Jg., 5, S. 425-440.

Gibson, C.B. \& Manuel, J.A. (2003): Building trust. Effective multicultural communication processes in virtual teams, in: Gibson, C.B. \& Cohen, S.G. (Hrsg.): Virtual teams that work. Creating conditions for virtual team effectiveness, San Francisco: Jossey-Bass, S. 59-86.

Goldstein D.L. \& Smith, D.H. (1999): The Analysis of the Effects of Experiential Training on Sojourners Cross-cultural Adaptability, in: International Journal of Intercultural Relations, Vol. 23, 1, p. 157-173.

Harvey, M. (1997): Dual-Career Expatriates: Expectations, Adjustment and Satisfaction with International Relocation, in: Journal of International Business Studies, 28 Jg., 3, S. 627-658.

Harvey, M., Speier, C. \& Novecevic, M.M. (2001): A Theory-based Framework for Strategic Global Human Resource Staffing Policies and Practices, in: International Journal of Human Resource Management, Vol. 12, 6, p. 898-915.

Harzing, A.-W. (2001): Who's in Charge? An Empirical Study of Executive Staffing Practices in Foreign Subsidiaries, in: Human Resource Management, Vol. 40, 2, p. 139-158.

Hennart J.-F. (1988): A Transaction Costs Theory of Equity Joint Ventures, in: Strategic Management Journal, Vol. 9, 4, p. 361-374.

Hertel, G., Geister, S. \& Konradt, U. (2005): Managing virtual teams. A review of current empirical research, in: Human Resource Management Review, 15. Jg., 1, S. 69-95.

Holtbrügge, D. (2003): Personalmanagement in Multinationalen Unternehmungen, in: Holtbrüge, D. (Hrsg.): Management Multinationaler Unternehmungen, Heidelberg: Physica-Verlag, S. 99-215.

Holtbrügge, D., Kittler, M.G. \& Rygl, D. (2004): Konfiguration und Koordination internationaler Dienstleistungsunternehmungen, in: Gardini, M.A. \& Dahlhoff, H.D. (Hrsg.): Internationales Dienstleistungsmanagement. Kontext-Konzepte-Erfahrungen, Wiesbaden: Gabler, S. 159-179. 
Holtbrügge, D. \& Schillo, K. (2006): Virtuelle Auslandsentsendungen, in: Wirtschaftswissenschaftliches Studium (WiSt), 35. Jg., 6, S. 320-324.

Iten, P.A. (2001): Virtuelle Auslandseinsätze von Mitarbeitern, in: Zeitschrift Führung \& Organisation, 70. Jg., 3, S. 168-174.

Kayworth, T. \& Leidner, D. (2000): The global virtual manager: a prescription for success, in: European Management Journal, 18. Jg., 2, S. 183-194.

Mayerhofer H., Hartmann L.C., Michelitsch-Riedl G. \& Kollinger I. (2004): Flexpatriate Assignments: A Neglected Issue in Global Staffing, in: International Journal of human Resource Management, 15. Jg., 8, S. 1371-1389.

Porter, M. E. (1989): Globaler Wettbewerb, Wiesbaden: Gabler.

PricewaterhouseCoopers (2000): Managing a Virtual World. International Non-standard Assignments, Policy and Practice, Europe: PricewaterhouseCoopers.

Rosenzweig, P.M. \& Nohira, N. (1994): Influences in Human Resource Management Practices in Multinational Corporations, in: Journal of International Business Studies, Vol. 25, 2, p. 229-251.

Scullion, H. (1994): Staffing Polices and Strategic Control in Multinationals, in: International Studies of Management and Organization, 3. Jg., 4, S. 86-104.

Stroh, L.K. \& Caligiuri, P. (1998) Strategic Human Resources: A New Source for Competitive Advantage in the Global Arena, in: International Journal of human Resource Management, 9. Jg., 1, S. 1-17.

Tan, D. \& Mahoney, J.T. (2006): Why a Multinational Firm Chooses Expatriates: Integrating Resource-Based, Agency and Transaction Costs Perspectives, in: Journal of Management Studies, 43. Jg., 3, S. 457-484.

Tsang, E.W.K. (2000): Transaction Cost and Resource-based Explanations of Joint Ventures: A Comparison and Synthesis, in: Organization Studies, Vol. 21, 1, p. 215-242.

Welch, D.E., Worm, V. \& Fenwick, M. (2003): Are Virtual International Assignments Feasible?, in: Management International Review, 43. Jg., Special Issue 1, S. 48-57.

Welge, M. \& Holtbrügge, D. (2006): Internationales Management, 4. Aufl., Stuttgart: SchäfferPoeschel.

Wolf, J. (2008): Organisation, Management, Unternehmensführung. Theorien, Praxisbeispiele und Kritik, 3. Aufl., Wiesbaden: Gabler.

Wünderlich, N.V., Schumann, J.H., Wangenheim, F. v. \& Holzmüller, H.H. (2007): Ferngesteuerte Dienstleistungen. Betriebswirtschaftliche Spezifika, Terminologie und Herausforderungen für das Management, in: Holtbrügge, D., Holzmüller, H.H. \& Wangenheim, F. v. (Hrsg.): Remote Services. Neue Formen der Internationalisierung von Dienstleistungen, Wiesbaden: Deutscher Universitäts-Verlag, S. 3-26. 



\section{Kapitel 2 \\ Virtuelle Auslandsentsendungen. Konzeptionelle Grundlagen, Anwendungsbeispiele und Bewertung. ${ }^{1,2}$}

\section{Gliederung}

2.1 Traditionelle Formen der Besetzung von Fach- und Führungspositionen im Ausland

2.2 Neue Formen der Stellenbesetzung

2.3 Merkmale virtueller Auslandsentsendungen

2.4 Beispiele virtueller Auslandsentsendungen

2.5 Bewertung und Anwendungsvoraussetzungen virtueller Auslandsentsendungen

$1 \quad$ Autoren: Dirk Holtbrügge \& Katrin Schillo.

2 Veröffentlicht in Remote Services. Neue Formen der Internationalisierung von Dienstleistungen, hrsg. v. D. Holtbrügge, H. Holzmüller \& F. v. Wangenheim. Wiesbaden: Deutscher Universitäts-Verlag, 2007 , S. 27-37. 


\subsection{Traditionelle Formen der Besetzung von Fach- und Führungspositionen im Ausland}

Eines der zentralen Probleme internationaler Unternehmungen ist die effiziente Besetzung von Fach- und Führungspositionen im Ausland (vgl. Welge \& Holtbrügge, 2006, S. 223 ff.). Traditionell stehen diesen dazu drei Alternativen zur Verfügung, und zwar die Entsendung von Stammhausmitarbeitern, die Beschäftigung von lokalen Mitarbeitern und der Einsatz von Mitarbeitern aus Drittländern (vgl. Tab. 2-1).

\begin{tabular}{|c|c|c|c|}
\hline & Stammhausdelegierter & Lokaler Mitarbeiter & Drittlandangehöriger \\
\hline $\begin{array}{l}\text { V } \\
\text { O } \\
\text { R } \\
\text { T } \\
\text { E } \\
\text { I } \\
\text { E } \\
\text { L } \\
\text { E }\end{array}$ & $\begin{array}{l}\text { - leichtere Durchsetzung } \\
\text { einer einheitlichen Unterneh- } \\
\text { mungspolitik } \\
\text { - problemlose Kommunikation } \\
\text { und Koordination zwischen } \\
\text { Mutter- und Tochtergesell- } \\
\text { schaft } \\
\text { - leichterer Transfer von tech- } \\
\text { nischem und Management- } \\
\text { Know-how } \\
\text { - Erweiterung der Erfahrungen } \\
\text { der Stammhausmitarbeiter } \\
\text { - bessere Kenntnis der } \\
\text { Muttergesellschaft } \\
\text { - höhere Loyalität der } \\
\text { Entsandten gegenüber der } \\
\text { Muttergesellschaft }\end{array}$ & $\begin{array}{l}\text { - zumeist geringere Personal- } \\
\text { kosten } \\
\text { - leichtere Integration der } \\
\text { Tochtergesellschaft in das } \\
\text { Gastland } \\
\text { - Motivationssteigerung bei } \\
\text { den lokalen Mitarbeitern, da } \\
\text { sie auch Spitzenpositionen } \\
\text { erreichen können } \\
\text { - höhere Kontinuität in der } \\
\text { Tochtergesellschaft } \\
\text { - positive Auswirkungen auf } \\
\text { die Stellung der Tochterge- } \\
\text { sellschaft in der Öffentlich- } \\
\text { keit des Gastlandes }\end{array}$ & $\begin{array}{l}\text { - größeres Potenzial an } \\
\text { qualifizierten Kandidaten } \\
\text { - höhere Flexibilität in der } \\
\text { Personalbeschaffung, da auf } \\
\text { nationale Interessen keine } \\
\text { Rücksicht mehr genommen } \\
\text { werden muss } \\
\text { - befruchtender Austausch } \\
\text { von Informationen durch den } \\
\text { hohen Entsendungsanteil }\end{array}$ \\
\hline $\begin{array}{l}\mathbf{N} \\
\mathbf{A} \\
\mathbf{C} \\
\mathbf{H} \\
\mathbf{T} \\
\mathrm{E} \\
\mathbf{I} \\
\mathbf{L} \\
\mathrm{E}\end{array}$ & $\begin{array}{l}\text { - Demotivierung der inlän- } \\
\text { dischen Mitarbeiter durch } \\
\text { Bevorzugung der Stamm- } \\
\text { hausdelegierten } \\
\text { - erschwerte Anpassung an } \\
\text { die Gastlandbedingungen } \\
\text { - Gefährdung der Kontinuität } \\
\text { und des Betriebsklimas bei } \\
\text { häufig wechselnden Stamm- } \\
\text { hausdelegierten } \\
\text { - hohe Entsendungskosten } \\
\text { - familiäre Probleme } \\
\text { (insbesondere bei dual } \\
\text { career couples) }\end{array}$ & $\begin{array}{l}\text { - erschwerte Abstimmung } \\
\text { zwischen Mutter- und } \\
\text { Tochtergesellschaft } \\
\text { - höhere Kommunikations- } \\
\text { kosten } \\
\text { - Gefahr, dass bei Konflikten } \\
\text { aufgrund mangelnder } \\
\text { Loyalität den Gastland- } \\
\text { interessen zum Schaden der } \\
\text { Gesamtunternehmung } \\
\text { Vorrang eingeräumt wird }\end{array}$ & $\begin{array}{l}\text { - sehr hohe Entsendungs- } \\
\text { kosten } \\
\text { - zumeist geringe Vertrautheit } \\
\text { mit den Gastlandbedingun- } \\
\text { gen } \\
\text { - hoher Koordinationsaufwand } \\
\text { - hohe Anforderungen an } \\
\text { internationale Manager } \\
\text { - erschwerter Aufbau einer } \\
\text { länderübergreifenden } \\
\text { Corporate Identity }\end{array}$ \\
\hline
\end{tabular}

Tabelle 2-1: Vor- und Nachteile von alternativen Formen der Besetzung von Fach- und Führungspositionen im Ausland

Quelle: $\quad$ Welge \& Holtbrügge, 2006, S. 224.

Ein Vorteil von Stammhausdelegierten sind deren gute Kenntnisse der Muttergesellschaft, wodurch einerseits eine weltweit einheitliche Unternehmungspolitik einfacher umgesetzt werden kann und andererseits die Kommunikation und Koordination zwischen Tochter- und Muttergesellschaft erleichtert wird. Durch Stammhausdelegierte kann zudem Technologie- und Management-Know-how leichter in ausländische Tochtergesellschaften übertragen werden. Sie stehen außerdem der Muttergesellschaft loyaler gegenüber und können durch eine Entsendung ins Ausland Erfahrungen sammeln, wodurch die Wissensbasis der Unternehmung erweitert 
wird. Stammhausdelegierten fällt es jedoch schwerer, sich an die im Gastland vorherrschenden Bedingungen anzupassen. Genauso kann ein häufiger Wechsel der Delegierten die Kontinuität der Unternehmungsführung in der Tochtergesellschaft erschweren. Die hohen Kosten einer Entsendung, die durch die Vorbereitung, den Auslandsaufenthalt selbst und die Wiedereingliederung entstehen, stellen einen weiteren Nachteil von Stammhausdelegierten dar.

Der Einsatz lokaler Mitarbeiter verursacht dagegen zumeist weitaus geringere Personalkosten. Ebenso wird deren Integration in das Gastland erleichtert und ihre Motivation erhöht, da sie die Chance haben, Führungspositionen zu erreichen, die sonst Stammhausdelegierten vorbehalten wären. Dies wirkt sich wiederum positiv auf die Kontinuität der Unternehmungsführung aus und verbessert das Ansehen der Unternehmung im Gastland. Der Einsatz lokaler Mitarbeiter erschwert jedoch die Koordination und Kommunikation zwischen Mutter- und Tochtergesellschaft. Den im Vergleich zu Stammhausdelegierten eingesparten Entsendungskosten stehen somit hohe Kommunikationskosten gegenüber.

Die dritte Alternative, der Einsatz von Drittlandangehörigen, beinhaltet vor allem ein größeres Potenzial an qualifizierten Bewerbern und ermöglicht eine flexiblere Personalbeschaffung. Nachteile dieser Form der Stellenbesetzung sind neben den hohen Personalkosten der wie bei lokalen Mitarbeitern bestehende Koordinationsaufwand und die hohen Anforderungen an die internationale Mobilität. Zudem wird der Aufbau einer länderübergreifenden Corporate Identity erschwert.

\subsection{Neue Formen der Stellenbesetzung}

Da alle drei zuvor geschilderten Alternativen der Besetzung von Fach- und Führungspositionen im Ausland zahlreiche Nachteile aufweisen, werden in der Literatur seit kurzem verschiedene neuere Formen der Stellenbesetzung diskutiert. Im Zentrum der Überlegungen steht die Entsendung von Stammhausmitarbeitern, deren Entsendungsdauer im Vergleich zu traditionellen Delegationen jedoch deutlich reduziert wird (vgl. Harris et al., 2005).

Kurzfristige Auslandsentsendungen sind durch eine Entsendungsdauer von weniger als einem Jahr gekennzeichnet. Dadurch sollen die Kosten der Übersiedlung des Mitarbeiters und seiner Familie eingespart sowie die Dual-Career-Problematik reduziert werden. Zudem wird die Reintegration erleichtert.

Beim Internationalen Pendeln besitzt der Mitarbeiter zwei Tätigkeits- und Wohnorte, zwischen denen er alle ein bis zwei Wochen hin und her pendelt. Ein großer Vorteil dieser Entsendungsform ist, dass er dadurch jeweils nur für kurze Zeiträume von seiner Familie getrennt wird.

Bei Vielflieger-Entsendungen unternimmt der Mitarbeiter häufig Dienstreisen ins Ausland. Dabei kann es sich im Unterschied zum internationalen Pendeln um zwei oder mehr Tochterge- 
sellschaften handeln. Auch dadurch sollen vor allem die Trennungsproblematik reduziert und das Reintegrationsproblem umgangen werden. Zudem wird die Heterogenität internationaler Erfahrungen der Mitarbeiter erweitert.

Diese neuen Formen der Stellenbesetzung weisen gegenüber traditionellen Ansätzen mehrere Vorteile auf. Aus Sicht des Mitarbeiters zählt dazu vor allem die Möglichkeit, sein bisheriges Privatleben im Heimatland zumindest teilweise weiterführen zu können. Dies ist insbesondere bei Entsendungen an wenig attraktive Tätigkeitsorte von großer Bedeutung. Ein großer Vorteil für die Unternehmung sind die deutlich reduzierten Entsendungskosten, denen jedoch höhere Reisekosten gegenüber stehen. Zudem können die dargestellten neueren Formen der Auslandsentsendung flexibler genutzt werden. Im Unterschied zu Expatriates werden die entsprechenden Mitarbeiter deshalb auch als Flexpatriates bezeichnet (vgl. Mayerhofer et al., 2004).

Trotz dieser Vorteile werden jedoch nicht alle Nachteile der traditionellen Ansätze überwunden. So wird in einer empirischen Untersuchung von Harris et al. (2005, S. 282 ff.) die räumliche Trennung von Berufs- und Privatleben als problematisch angesehen. Diese führt vor allem bei internationalen Pendlern und Vielfliegern zu hohen physischen und psychischen Belastungen. Alle drei Formen verursachen darüber hinaus hohe Reisekosten. In vielen Unternehmungen fehlen hierzu zudem noch detaillierte Richtlinien, wodurch die Unsicherheit für den Entsandten erhöht wird. Nicht zuletzt sind viele Steuer- und Versicherungsfragen noch nicht gelöst.

Als weitere neue Form der Stellenbesetzung im Ausland werden deshalb in jüngster Zeit vielfach virtuelle Auslandsentsendungen vorgeschlagen. Im Unterschied zu den zuvor genannten Formen der Besetzung von Fach- und Führungspositionen im Ausland findet dabei kein Wechsel des Tätigkeitsortes statt. Die Merkmale, Vor- und Nachteile sowie Anwendungsvoraussetzungen virtueller Auslandsentsendungen werden im Folgenden ausführlich erläutert.

\subsection{Merkmale virtueller Auslandsentsendungen}

Der Begriff der Virtualität wurde im Jahre 1993 von Davidow und Malone in die organisationstheoretische Literatur eingeführt und schnell auf zahlreiche Anwendungsbereiche übertragen. Virtuell ,steht dabei für nicht wirklich, scheinbar oder der Anlage nach vorhanden. Als virtuell wird damit generell die Eigenschaft einer Sache bezeichnet, die zwar nicht real, aber doch in der Möglichkeit (bzw. Leistungsfähigkeit) existiert“" (Scholz, 2000, S. 320 f.).

Eine große Verbreitung hat der Begriff der Virtualität vor allem auf der Organisationsebene gefunden. Virtuelle Organisationen stellen ,eine durch Informations- und Kommunikationssysteme unterstützte Kooperation rechtlich unabhängiger Einheiten (dar), die durch die Einbringung spezifischer Kernkompetenzen eine Leistung in zeitlicher und räumlicher Autonomie auf Basis eines gemeinsamen Geschäftsverhältnisses erbringt und dabei selbst alle Unternehmenseigenschaften aufweist“" (Pieles, 2004, S. 59). Ein zentraler Vorteil virtueller Organisationen ist die hohe Flexibilität. Da viele Ressourcen nicht permanent physisch vorhanden sind, sondern je 
nach Bedarf temporär beschafft und kombiniert werden, können virtuelle Organisationen sehr schnell auf veränderte Marktbedingungen reagieren. Zudem weisen sie oft fachliche und regionale Spezialisierungsvorteile auf. Mit diesen Flexibilitäts- und Spezialisierungsvorteilen sind jedoch zahlreiche Führungs- und Kontrollprobleme verbunden (vgl. Picot et al., 2003).

Auf der Gruppenebene wird der Begriff der Virtualität vor allem im Zusammenhang mit länderübergreifenden Teams (virtual global teams) verwendet. Hierunter werden Gruppen verstanden, deren Mitglieder sich an unterschiedlichen Orten aufhalten und mit Hilfe elektronischer Informations- und Kommunikationstechnologien über Raum, Zeit und Unternehmungsgrenzen hinweg zusammenarbeiten (vgl. Scholz \& Stein, 2003). Vorteile virtueller Teams sind die Reduzierung von Reisekosten sowie die zeit- und ortsunabhängige Zusammenarbeit. Darüber hinaus wird die Verständigung von Angehörigen unterschiedlicher Sprachräume durch die Nutzung elektronischer Kommunikationsmedien erleichtert. Der Verzicht auf persönliche Kommunikation erschwert jedoch den Transfer impliziten Wissens, der gerade bei anspruchsvollen Tätigkeiten von großer Bedeutung ist (vgl. Jarvenpaa \& Leidner, 1999; Montoya-Weiss et al., 2001).

Eine weit verbreitete Form der Virtualisierung auf der Individualebene ist die Telearbeit (vgl. Holtbrügge 2005, S. 133 ff.). Dabei sind die Mitarbeiter nicht mehr physisch in der Unternehmung anwesend, sondern nur noch elektronisch an diese gekoppelt. Ein wesentlicher Vorteil dieser Arbeitsform ist die bessere Vereinbarkeit von Berufs- und Privatleben (life-work-balance). Dem stehen jedoch der Verlust persönlicher Kontakte und die Gefahr sozialer Isolation gegenüber.

Überträgt man den Begriff der Virtualität auf die Besetzung von Fach- und Führungspositionen im Ausland, so lässt sich darunter ein Mitarbeiter verstehen, der sich physisch im Heimatland aufhält, jedoch vor allem mit Personen in anderen Ländern zusammen arbeitet (vgl. Holtbrügge \& Schillo 2006, S. 322). Im Unterschied zu den in den beiden vorangegangenen Abschnitten genannten Formen sind virtuelle Auslandsentsendungen somit durch das Auseinanderfallen zwischen dem Tätigkeits- und Wohnort im Heimatland und den Interaktionspartnern im Gastland gekennzeichnet. Bei diesen kann es sich um Mitarbeiter der gleichen Unternehmung oder von Kooperationspartnern, Kunden sowie Lieferanten handeln. Dabei reicht es nicht aus, dass sich Wohnsitz und Arbeitsplatz im Heimatland und die Aktionspartner im Ausland befinden. Entscheidend ist neben der geographischen Trennung zwischen physischer und virtueller Arbeitswelt auch die kulturelle und sprachliche Trennung.

Die Interaktion verläuft bei virtuellen Auslandsentsendungen zu einem wesentlichen Teil über elektronische Informations- und Kommunikationstechnologien, wobei regelmäßige persönliche Treffen nicht ausgeschlossen sind. Entscheidend ist jedoch, dass unmittelbare Kontakte zwischen dem virtuellen Entsandten und seinen Interaktionspartnern im Gastland auf wenige Treffen beschränkt sind. Die Möglichkeit zum Aufbau enger persönlicher Beziehungen geht dadurch weitgehend verloren. 
Ein drittes zentrales Merkmal virtueller Auslandsentsendungen ist, dass der virtuelle Entsandte gegenüber seinen Mitarbeitern im Ausland ein Weisungsrecht und gegenüber einen Kunden, Lieferanten oder Kooperationspartnern ein Entscheidungsrecht besitzt. Dies unterscheidet virtuelle Entsandte etwa von den Mitarbeitern von Call Centern, die häufig auch die geographische Trennung von Arbeitsort und Interaktionspartnern kennzeichnet. Weisungsgebundenheit kann sowohl gegenüber Vorgesetzten im Heimat- als auch im Gastland bestehen.

Virtuelle Auslandsentsendungen müssen schließlich dauerhaft sein und dürfen sich nicht nur auf ein einziges Projekt beschränken. Dies bedeutet, dass die virtuelle Auslandsentsendung eine wichtige Karrierephase darstellt, von deren Erfolg etwa zukünftige Beförderungsentscheidungen abhängen. Wie bei realen Auslandsentsendungen sind dabei unterschiedliche Ausgestaltungsformen denkbar (vgl. Abb. 2-1).

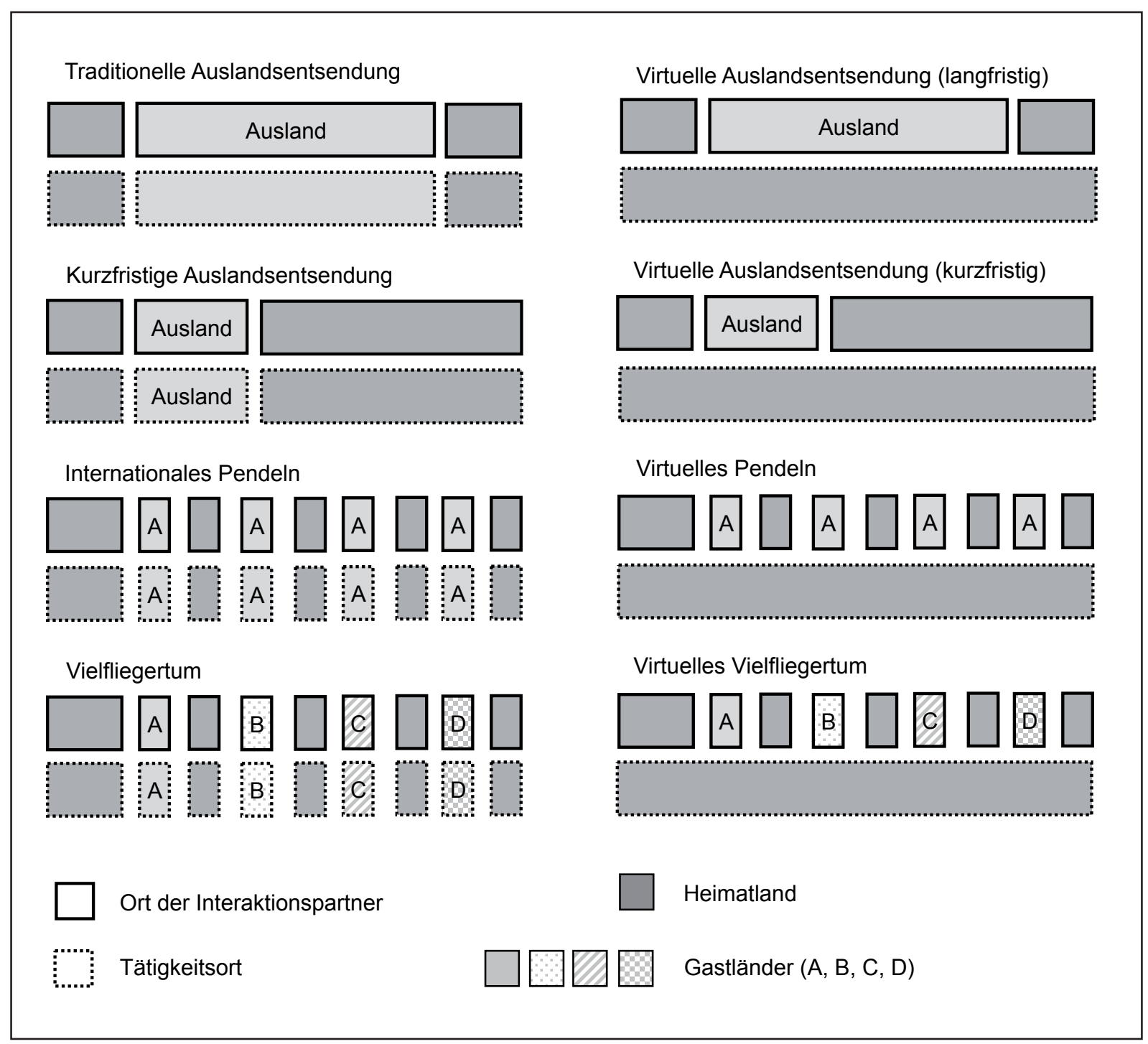

Abbildung 2-1: Merkmale realer und virtueller Auslandsentsendungen 
Vergleicht man virtuelle mit realen Auslandsentsendungen, so fällt als zentraler Unterschied die räumliche Trennung von Privat- und Berufsleben auf. Der virtuelle Entsandte lebt in seiner eigenen (Heimat-)Kultur, interagiert jedoch den größten Teil seiner Arbeitszeit mit Angehörigen anderer Kulturen, die in einem anderen Land tätig sind. Wo ein realer Entsandter die andere Kultur wahrhaftig erlebt, also hört, riecht, sieht und schmeckt, ist der virtuelle Entsandte auf deren Wahrnehmung über elektronische Informations- und Kommunikationstechnologien beschränkt. Unmittelbar erlebt wird nur die eigene Heimatkultur. Beispielhaft stellt man sich einen realen Entsandten in China vor, der mit seinen Kunden oder Kollegen abends in ein chinesisches Restaurant zum Essen geht, sich von diesen die Speisekarte übersetzen lassen muss und mit Stäbchen landestypische Spezialitäten isst. Im Gegensatz holt sich der virtuelle Entsandte vielleicht mittags in der Kantine eine Currywurst mit Pommes und fährt nach der Arbeit wieder in sein Vorstadtreihenhaus zu seiner Familie zurück.

\subsection{Beispiele virtueller Auslandsentsendungen}

Eine der ersten Unternehmungen, die explizit den Begriff „virtuelle Auslandsentsendung“ verwendet, ist der amerikanische Computerhersteller IBM. Die Dauer von virtuellen Auslandseinsätzen ist im Virtual-Assignment-Program der Unternehmung auf mindestens ein Jahr und maximal drei Jahre festgelegt. In dieser Zeit steht der virtuelle Entsandte unter der Leitung der ausländischen Niederlassung und kann weitgehend frei wählen, ob er das Büro im Heimatland oder im Gastland nutzen will, oder ob er von zuhause aus arbeitet. Er muss während des Programms mindestens 40 Tage pro Jahr in der ausländischen Niederlassung verbringen, darf sich aber aus steuerrechtlichen Gründen nicht länger als 183 Tage dort aufhalten. Die Leistungsbeurteilung erfolgt durch jeweils einen Vorgesetzten im Heimatland und im Gastland. Nach den Erfahrungen von IBM eignen sich für virtuelle Entsendungen vor allem die folgenden Tätigkeiten: Projektorientierte interne Aufgaben, externe und interne Beratung, Führung von kleinen internationalen Teams, Koordination von Aktivitäten, Marketing Programme und Business Development (vgl. Iten, 2001, S. 170).

Ein weiteres Anwendungsbeispiel für virtuelle Auslandsentsendungen bei Remote Services ist SAP (vgl. Ohr et al., 2007). So werden z.B. in der Abteilung System Landscape Optimization viele Projekte der Systemimplementierung und -wartung bei ausländischen Kunden durch Mitarbeiter in der Unternehmungszentrale durchgeführt, die dabei von Vertriebsmitarbeitern vor Ort unterstützt werden. Dadurch ist SAP in der Lage, bei komplexen Problemen Fachkräfte aus unterschiedlichen Bereichen kurzfristig und flexibel einsetzen zu können. Da es sich bei diesen häufig um hochgradige Spezialisten handelt, wäre deren Auslandseinsatz im Rahmen einer traditionellen Entsendung zu kostspielig, um die Leistung noch wettbewerbsfähig anbieten zu können. Derartige virtuelle Entsendungen können von wenigen Stunden bis zu einem Jahr dauern. 
Ein Beispiel für virtuelles Vielfliegertum ist die Heidelberger Druckmaschinen AG (vgl. Wünderlich \& Pfeffer, 2007). So werden seit der Einführung von Remote Servies Mitarbeiter bei Störfällen nicht mehr persönlich zum Kunden gerufen, sondern über ein eigens entwickeltes System virtuell „eingeflogen“. Treten bei einem Kunden irgendwo auf der Welt Probleme auf, so werden die Servicemitarbeiter von Heidelberger automatisch darüber benachrichtigt. Nach Freigabe durch den Kunden können sich die Servicemitarbeiter in dessen System einloggen und die Fehler beheben. So kann es passieren, dass ein Mitarbeiter binnen kürzester Zeit virtuell mit Kunden in Deutschland, den USA und Asien interagiert.

\subsection{Bewertung und Anwendungsvoraussetzungen virtueller Auslandsentsendungen}

Der offensichtlichste Vorteil virtueller Auslandsentsendungen ist der Verbleib des virtuellen Entsandten am Heimatort. Hierdurch werden nicht nur Entsendungs- und Übersiedlungskosten gespart, sondern auch die Reisekosten stark reduziert. Ebenso verringert sich die physische und psychische Belastung des Entsandten, da ihre Reisetätigkeit sowie die Trennung von der Familie verkürzt werden (vgl. Welch et al., 2003, S. 103). Das Privatleben im Heimatland kann so problemlos weitergeführt werden und die Dual-Career-Problematik wird entschärft. Dies ist besonders bei Tätigkeiten an unattraktiven Orten relevant. Zugleich wird die Reintegration nach Beendigung der virtuellen Entsendung erleichtert, da der Kontakt zu den Kollegen im Stammhaus aufrechterhalten bleibt. Zudem können die Mitarbeiter noch flexibler als beim Vielfliegertum eingesetzt werden. Eine Studie von PricewaterhouseCoopers (2000) zeigt, dass virtuelle Entsendungen deshalb eine hohe Akzeptanz bei Mitarbeitern besitzen und deren Verbreitung in den nächsten Jahren stark zunehmen dürfte.

Der Verbleib am Heimatort ist andererseits aber auch ein großer Nachteil virtueller Entsendungen. Durch die räumliche Trennung von den Interaktionspartnern im Gastland werden persönliche Kontakte und die Möglichkeit der Vertrauensbildung auf ein Minimum reduziert (vgl. Grundgreif et al., 2007). Die Kommunikation ist hauptsächlich auf die Nutzung von elektronischen Informations- und Kommunikationstechnologien beschränkt und fordert von allen Interaktionspartnern die Fähigkeit, diese entsprechend zu nutzen. Vom virtuellen Entsandten wird eine hohe interkulturelle Kompetenz erwartet, da er seine Interaktionspartner ohne persönlichen Kontakt verstehen und mit diesen effizient zusammen arbeiten muss. Dies betrifft vor allem die Führung, Motivation und Kontrolle von ihm unterstellten Mitarbeitern, die permanent in einem anderen Land tätig sind (distance leadership) (vgl. Steinle et al., 2005). Virtuelle Auslandsentsendungen erfordern deshalb eine spezifische Form der Vorbereitung, die nicht nur den virtuellen Entsandten, sondern auch dessen wichtigste Interaktionspartner im Gastland umfassen sollte (vgl. Holtbrügge \& Schillo, 2008; Peppas, 2004).

Die im vierten Abschnitt dargestellten Beispiele machen deutlich, dass sich virtuelle Auslandsentsendungen vor allem für solche Branchen eignen, die sich durch eine hohe Fernsteuerbar- 
keit (remoteability) von Prozessen auszeichnen. Dazu zählen vor allem länderübergreifende Dienstleistungen. Mit der zunehmenden Automatisierung der Produktion steigt jedoch auch in vielen Industriebereichen die Möglichkeit, virtuelle Auslandsentsendungen einzusetzen.

Neben der Branche hängt die Effizienz virtueller Auslandsentsendungen von den kulturellen Merkmalen des Gastlandes ab. Sie eignen sich vor allem in Low-Context-Kulturen, in denen die Informationsübermittlung weitgehend direkt und explizit erfolgt (vgl. Hall, 1976). Dagegen stellt der weitgehende Verzicht auf persönliche Interaktionen in High-Context-Kulturen wie China oder Japan ein besonders großes Problem dar. Da in diesen Ländern ein Großteil der Information implizit durch Gestik, Mimik, Stimmlage und anderen Formen der non-verbalen Kommunikation vermittelt wird, ist die Gefahr von Missverständnissen in diesen Kulturen besonders groß. Zudem erfordert die erfolgreiche Tätigkeit in diesen Ländern die langfristige Herausbildung von Vertrauen, die ohne regelmäßige persönliche Kontakte kaum möglich ist.

Neue Entwicklungen der elektronischen Informations- und Kommunikationstechnologie werden in Zukunft die Möglichkeiten virtueller Auslandsentsendungen verbessern und zu deren weiterer Verbreitung beitragen. Der schnellen Entwicklung neuer Technologien steht jedoch die relative Trägheit von Werten, Normen und Einstellungen gegenüber. Wie bei realen Entsendungen stellen die sachgerechte Auswahl, Vorbereitung, Betreuung und Repatriierung aller beteiligten Mitarbeiter deshalb auch bei virtuellen Auslandsentsendungen letztlich die zentralen Erfolgsfaktoren dar. 


\section{Literaturverzeichnis}

Davidow, W.H. \& Malone, M.S. (1993): Das virtuelle Unternehmen. Der Kunde als Co-Produzent, Frankfurt a. M.: Campus.

Grundgreif, D., Holtbrügge, D. \& Schillo, K. (2007): Problemfelder virtueller Auslandsentsendungen. Ergebnisse einer empirischen Studie, in: Holtbrügge, D., Holzmüller, H.H. \& Wangenheim, F. v. (Hrsg.): Remote Services. Neue Formen der Internationalisierung von Dienstleistungen, Wiesbaden: Deutscher Universitäts-Verlag, S. 41-65.

Hall, E. (1976): Beyond Culture, New York: Anchor.

Harris, H., Brewster, C. \& Erten, C. (2005): Auslandseinsatz, aber wie?, in: Stahl, G.K., Mayrhofer, W. \& Kühlmann, T.M. (Hrsg.): Internationales Personalmanagement, München/Mering: Hampp, S. 272-291.

Holtbrügge, D. (2005): Personalmanagement, 2. Aufl., Berlin: Springer.

Holtbrügge, D., Holzmüller, H.H. \& Wangenheim, F. v. (Hrsg.) (2007): Remote Services. Neue Formen der Internationalisierung von Dienstleistungen, Wiesbaden: Deutscher UniversitätsVerlag.

Holtbrügge, D. \& Schillo, K. (2006): Virtuelle Auslandsentsendungen, in: Wirtschaftswissenschaftliches Studium (WiSt), 35. Jg., 6, S. 320-324.

Holtbrügge, D. \& Schillo, K. (2008): Intercultural Training Requirements for Virtual Assignments: Results of an Explorative Empirical Study, in: Human Resource Development International, Vol. 11, 3, p. 271-286.

Iten, P.A. (2001): Virtuelle Auslandseinsätze von Mitarbeitern, in: Zeitschrift Führung \& Organisation, 70. Jg., 3, S. 168-174.

Jarvenpaa, S.L. \& Leidner, D.E. (1999): Communication and Trust in Global Virtual Teams, in: Organization Science, 10. Jg., 6, S. 791-815.

Mayerhofer, H., Hartmann, L.C., Michelitsch-Riedl, G. \& Kollinger, I. (2004): Flexpatriate Assignments: A Neglected Issue in Global Staffing, in: International Journal of Human Resource Management, 15. Jg., 15, S. 1371-1389.

Montoya-Weiss, M.M., Massey, A.P. \& Song, M. (2001): Getting it together: Temporal Coordination and Conflict Management in Global Virtual Teams, in: Academy of Management Journal, 44. Jg., 6, S. 1251-1262.

Ohr, A., Holtbrügge, D., Schillo, K. \& Wagner, M. (2007): Remote Services in Softwareunternehmungen. Das Beispiel SAP, in: Holtbrügge, D., Holzmüller, H.H. \& Wangenheim, F. v. (Hrsg.): Remote Services. Neue Formen der Internationalisierung von Dienstleistungen, Wiesbaden: Deutscher Universitäts-Verlag, S. 141-167.

Peppas, S.C. (2004): Making the Most of International Assignments: A Training Model for Nonresident Expatriates, in: Journal of the American Academy of Business, 5. Jg., 1/2, S. 41-45.

Picot, A., Reichwald, R. \& Wigand, R.T. (2003): Die grenzenlose Unternehmung, 5. Aufl., Wiesbaden: Gabler.

Pieles, H. (2004): Die Strategische Planung im Rahmen Virtueller Unternehmen. Eine Analyse auf Basis der Koordinationstheorie, Aachen: Shaker.

PricewaterhouseCoopers (2000): Managing a Virtual World, Key Trends 2000/2001, PricewaterhouseCoopers Europe.

Scholz, C. (2000): Strategische Organisation, 2. Aufl., Landsberg/Lech: Moderne Industrie.

Scholz, C. \& Stein, V. (2003): Internationale Virtuelle Teams: „Against all odds!“, in: Holtbrügge, D. (Hrsg.): Management Multinationaler Unternehmungen, Heidelberg: Physica, S. 233-246.

Steinle, C., Ahlers, F. \& Eichenberg, T. (2005): Phasen einer Führung auf Distanz, in: Personalwirtschaft, 32. Jg., 7, S. 15-17. 
Welch, D.E., Worm, V. \& Fenwick, M. (2003): Are Virtual International Assignments Feasible?, in: Management International Review, 43. Jg., Special Issue 1, S. 48-57.

Welge, M. \& Holtbrügge, D. (2006): Internationales Management, 4. Aufl., Stuttgart: SchäfferPoeschel.

Wünderlich, N.V. \& Pfeffer, M. (2007): Internetbasierte Remote Services bei der Heidelberger Druckmaschinen AG, in: Holtbrügge, D., Holzmüller, H.H. \& Wangenheim, F. v. (Hrsg.): Remote Services. Neue Formen der Internationalisierung von Dienstleistungen, Wiesbaden: Deutscher Universitäts-Verlag, S. 169-178. 



\section{Kapitel 3 \\ Virtual Delegation Across Borders: \\ A Knowledge-based Perspective., ${ }^{1,2}$}

\section{Contents}

3.1 Problem and Objectives

3.2 Theory and Hypotheses: A Knowledge-based View of Virtual Assignments

3.2.1 Intensity of Knowledge Transfer and Use of Virtual Delegations

3.2.2 Direction of Knowledge Transfer and Use of Virtual Delegations

3.2.3 Mode of Knowledge Transfer and Use of Virtual Delegations

3.3 Methodology

3.3.1 Sample

3.3.2 Measures

3.3.2.1 Dependent Variables

3.3.2.2 Independent Variables

3.3.2.3 Control Variables

3.4 Results and Discussion

3.5 Contributions, Limitations and Implications for Future Studies 


\subsection{Problem and Objectives}

Multinational corporations (MNCs) frequently use expatriates to manage their foreign operations. While expatriations have their particular advantages, e.g., in controlling foreign subsidiaries or in disseminating knowledge across MNC units, there are many disadvantages as well. For example, the high delegation costs for the headquarters, (including fringe benefits, training costs, travel and relocation costs, additional health insurance, tax equalization or private school fees) (Dowling \& Welch, 2004; Fenwick, 2004). Failure rates are high due to inadequate adjustment to the host country culture, dual career problems and other reasons (e.g., Caligiuri \& Tung, 1999; Pires et al., 2006; for a critical view see Harzing, 1995). Moreover, several studies reveal that expatriates often experience severe repatriation problems, which increase with the duration of their foreign assignment (Konopaske \& Werner, 2005).

Owing to these problems, new alternatives such as short-term delegations, international commuter arrangements and frequent flyer assignments are becoming increasingly popular in many MNCs (Collings et al., 2007; Harris et al., 2005). Their main objective is to reduce delegation costs and repatriation problems. Furthermore, they also seek to increase the recruitment flexibility, as personal and family restrictions are less likely. The most innovative and radical alternative to traditional expatriation is virtual delegation, which will be the focus of this paper.

According to PricewaterhouseCoopers (2000, p. 31) an international delegation is called virtual when "an employee does not relocate to a host location, but has international responsibilities for a part of the organization in another country which they manage from the home country". Virtual delegates remain in their home country most of the time. In comparison with expatriates, virtual delegates are not delegated abroad. They work in the headquarters and interact mostly (approximately $80 \%$ of the time) with colleagues, customers or suppliers in a foreign country. Hence, virtual delegates are characterized by the spatial and psychic separation of private and work life. The virtual delegate lives and interacts in one culture, yet he or she works together mainly with people from another culture. While the virtual delegate is physically located in the headquarters, from an organizational and operational point of view, he or she mainly interacts with individuals in a foreign country, where he or she is responsible for management and technical tasks (Holtbrügge \& Schillo, 2008a).

A major advantage of virtual delegates compared to traditional expatriates is the ability to work abroad without actually going abroad. Hence virtual expatriates work internationally without leaving their familiar surrounding. The time of absence is reduced, which improves the work/ life balance. Another advantage is that the family does not have to be relocated. This enables children to follow their education and spouses to maintain their own career, which avoids conflicts within the family and dual-career problems. Likewise, the repatriation of virtual expatriates is much easier. Virtual delegates never lose contact to the headquarters and their local colleagues because they remain integrated into its decision-making processes and networks. 
Moreover, virtual assignments are often cheaper than traditional forms of expatriation as for example, a salary premium as compensation for relocation abroad is not necessary. Finally, no training for family members is needed since they remain in the home country.

An example of where virtual delegates are frequently used is the German software company SAP (Holtbrügge \& Schillo, 2008a). In the department "System Landscape Optimization" (SLO) 80 highly qualified IT experts are employed to support a large number of customers and local staff members all over the world. Their major task is the optimization of existing IT systems. In many client companies, different departments have their own IT systems with various versions and customized solutions of the standard software, which must be consolidated and migrated into one new system at once. Such projects, from the first presentation of the concept to its final implementation, last up to one year or even longer. During that time, most tasks are managed and carried out by virtual delegates in Germany who possess the necessary technical and administrative knowledge. Local employees act as the contact people at the customer's location and are aimed to guarantee the local adoption of knowledge. For the duration of the project they are subordinated to the virtual delegate in Germany. Business trips take place rarely. The virtual delegates only meet customers or colleagues in the foreign subsidiary face-to-face if and when important milestones are reached. Most of the time communication takes place instead via electronic media. Thus, the main tasks of virtual delegates are to transfer knowledge to a foreign subsidiary by teaching and assisting local staff, as well as to coordinate and control them.

Another example is the Remote Services Department at Siemens Medical Solutions (Bechtold, 2007). More than 200 experts in the headquarters provide support as virtual delegates to customers across the world (including hospitals, physicians and research institutes). Every year more than 99,000 performance updates are installed via Internet. Furthermore x-ray machines, computer tomographs and other medical equipment are maintained remotely. Each virtual delegate is responsible for a particular country or region and not only interacts with customers but also teaches, coordinates and controls local staff members such as IT-specialists, technicians and salespeople. Hence virtual delegates displace host-country managers to reduce cost and to ensure the global standardization of services.

Over the last few years several conceptual studies on virtual assignments have been published, e.g. on their advantages and disadvantages compared to traditional assignments (e.g., PricewaterhouseCoopers, 2000; Welch et al., 2003; Fenwick, 2004), possible fields of their application (e.g., Holtbrügge \& Schillo, 2008a) and their requirements for intercultural training (Holtbrügge \& Schillo, 2008b). However, little is known, as to which determinants support the use of virtual assignments. In particular their relationship to knowledge transfers between headquarters and subsidiaries is unclear.

The aim of this paper is therefore to explore the conditions under which virtual delegates are used in practice. More specifically, the knowledge-based view is applied to analyze whether the 
use of virtual delegates depends on the intensity, direction and mode of knowledge transfers between the geographically dispersed units of a MNC. In analyzing this role of virtual delegates we aim to make three important contributions. First, the literature on foreign assignments will be extended by theoretical and empirical insights into a new form of staffing overseas positions. Secondly, we will analyze the relationship of virtual delegates to knowledge transfers in MNCs, thus contributing to the literature on intra-organizational knowledge management. And thirdly, we aim to assist managers in deciding under which conditions virtual delegates may be used.

The paper is organized as follows. In the next section, the knowledge-based view will be applied to virtual delegation and three research hypotheses will be derived. The methodology of the study will then be explained, followed by the presentation and discussion of the key results. The paper ends with a summary of the main contributions and limitations of the study as well as some suggestions for future research.

\subsection{Theory and Hypotheses: A Knowledge-based View of Virtual Assignments}

The role of expatriates as vehicles for disseminating knowledge across MNC units is gaining in importance. As a consequence, foreign assignments are often analyzed from a knowledgebased view (e.g., Bonache \& Brewster, 2001; Downes \& Thomas, 2000; Minbaeva and Michailova, 2004; Tsang, 1999).

According to the knowledge-based view, the collection, development, and exploitation of organizational knowledge is a main success factor of MNCs. Organizational knowledge can be defined as a context-specific, relational and action-oriented network of information that organizations develop in order to interact with their environment (Nonaka \& Takeuchi, 1995, p. 57). As Bartlett and Ghoshal (1987, p. 37) recognize, knowledge management, that is "the ability to learn - to transfer knowledge and expertise from one part of the organization to others worldwide - became more important in building durable competitive advantage". Similarly, Gupta and Govindarajan (1991, p. 772) argue that, in addition to capital and product flows, "knowledge flows across subsidiaries become particularly significant". The main reason for this is that knowledge is very difficult to imitate and to adopt, thus, compared to products, technologies and other resources, building a more reliable and sustainable source of competitive advantage (e.g., Adams \& Lamont, 2003; Grant, 1996; Meso \& Smith, 2000).

In line with Argote and Ingram (2000), the knowledge of an organization is embedded in its members, tools and tasks, the so-called 'knowledge reservoirs'. Transferring knowledge within an organization or MNC means therefore to transfer knowledge reservoirs and to adapt them to the new context.

MNCs may apply various instruments of knowledge transfer such as manuals, reports, e-mails, web sites, intranets, telephone calls, video conferences or delegations of headquarters expatriates. The use of these instruments for knowledge transfer has been intensively analyzed in 
recent studies (e.g., Gupta \& Govindarajan, 2000; Holtbrügge \& Berg, 2004; Minbaeva et al., 2003). One important result is that foreign delegations may enhance knowledge flows within MNCs. These studies, however, are limited to traditional forms of expatriation and do not take into account new instruments such as virtual delegates. The aim of this study is therefore to close this research gap and to explore if the use of virtual delegates depends on the intensity, direction and mode of for knowledge transfer. More specifically, the influence of the intensity, direction and form of knowledge transfer on virtual delegations will be analyzed.

\subsubsection{Intensity of Knowledge Transfer and Use of Virtual Delegations}

According to the knowledge-based view, MNCs are required to develop and to collect as well as to protect knowledge against imitation by others. Moreover, knowledge should be transferred between the geographically dispersed units. For example, a subsidiary in a lead market may share its experience of the introduction of a new product with subsidiaries in other countries where the launch will take place later. Similarly, a patent which was developed in one country is more useful, if it can be applied in other countries as well (e.g., Beise, 2001).

Virtual assignments are argued to be an appropriate instrument to support the transfer of knowledge within a MNC. The ambiguous character of virtual delegates - living physically in one country while working in another - makes them aware of the differences between the two. The simultaneous confrontation with two different physical, mental and emotional environments requires them to adopt knowledge permanently to the specific local context. Thus, virtual delegates can be regarded as commuters and boundary spanners between two worlds who permanently translate knowledge which was originally embedded in one context to another one (e.g., Au \& Fukuda 2002).

Several studies reveal that the subsidiaries of a MNC may have different roles (e.g., Gupta \& Govindarajan, 1991). While some subsidiaries may act rather autonomously, others can be highly integrated into the MNC-wide knowledge flows (Chini et al., 2005). For example, subsidiaries in core markets may share more knowledge with the headquarters while those in peripheral markets may be more isolated in terms of knowledge transfer.

We argue that the function of virtual delegates as boundary spanners is more important, the more knowledge is transferred. Highly integrated subsidiaries have a strong need for their ability to translate knowledge from one context to another. On the other hand, they are less needed when the intensity of knowledge flows is low. Thus, the following hypothesis can be derived:

\section{Hypothesis 1: The higher the intensity of knowledge transfer between headquarters and subsidiary, the more often virtual delegates are used.}




\subsubsection{Direction of Knowledge Transfer and Use of Virtual Delegations}

According to Gupta and Govindarajan (1991), MNCs can be thought of as a network of multidirectional knowledge transactions among units located in different countries. For each type of transaction subsidiaries can differ regarding the volume and criticality of knowledge flows. To the extent that subsidiaries engage in intra-MNC transactions, they can differ also regarding whether they are either the receivers or the providers of what is being transacted. Combining these two factors, any subsidiary of a MNC can be distinguished according to the extent to which it engages in knowledge inflows from and the extent to which it engages in knowledge outflows to other units of the MNC.

The transfer of knowledge, however, does not necessarily guarantee its efficient application. The receiving units must also develop a high "absorptive capacity", i.e. the "ability to recognize the value of new information, assimilate it, and apply it to commercial ends" (Cohen \& Levinthal, 1990, p. 128).

Empirical studies reveal that foreign delegations may be efficient instruments to enhance the absorptive capacity of a subsidiary. Since expatriates are physically located in the subsidiary, they are best suited to adapt knowledge inflows from the headquarters to the specific conditions under which the subsidiary operates (e.g., Björkman et al., 2004; Ghoshal et al., 1994; Harzing, 2001b). Virtual Delegates, on the contrary, are physically located in the headquarters. Thus, it can be argued that their particular strength is to consider the specific conditions of the home country, i.e. to enhance the absorptive capacity of the headquarters. Therefore, being physically located there, they are best suited to receive knowledge inflows from other parts of the MNC and to adapt it to the specific requirements of the headquarters. These considerations lead to the following hypothesis:

\section{Hypothesis 2: The higher the relevance of knowledge inflows from the subsidiary to the headquarters compared to knowledge outflows, the more often virtual delegates are used.}

\subsubsection{Mode of Knowledge Transfer and Use of Virtual Delegations}

With reference to the characteristics of knowledge flows we can distinguish between objective versus experiential knowledge (Penrose, 1959) and between explicit versus tacit knowledge (Polanyi, 1966). Objective or explicit knowledge, on the one hand, refers to knowledge that can be articulated either verbally or in writing (e.g., in manuals or mathematical expressions) and thus can be transmitted in formal, systematic language (e.g., in mails or reports). Experiential or tacit knowledge, on the other hand, is implicit, non-verbalized and therefore difficult to formalize and to communicate as it is embedded in individual experiences and involves personal 
beliefs, perspectives and value systems (Forsgren \& Hagström, 2007; Hedlund \& Nonaka, 1993; Nonaka \& Takeuchi, 1995).

Empirical studies (e.g., Holtbrügge \& Berg, 2004) underline that these two forms of knowledge require different mechanisms of transfer. Experiential or implicit knowledge can be best exploited through personal modes such as face-to-face communication. These allow the transfer of knowledge that the sender may be unaware of, that requires trust-creation between the sender and the receiver, and that needs to be adapted to different cultures, laws, and business practices (Pedersen et al., 2003). Moreover, personal modes of knowledge transfer proceed synchronously. The simultaneous attendance of sender and receiver enables more spontaneous forms of communication. Additionally, communication is not limited to verbal expressions but may include also non-verbal elements. Thus, the media richness of personal communication is high (Purdy \& Nye, 2000).

On the contrary, explicit or objective knowledge is more likely to be transferred through electronic media (Pedersen et al., 2003, p. 76). Electronic modes are able to transfer large amounts of data that is not possible through face-to-face interaction. Knowledge transfer through electronic media is also more precise because information may be digitalized and selective perceptions of individuals are less likely. However, the knowledge transfer is asynchronous and delayed, which complicates explanations and requests. Similarly, electronic modes are not able to transfer emotions easily (e.g., Jarvenpaa \& Leidner, 1999).

We argue that virtual delegations are more likely when the communication between headquarters and subsidiary takes place primarily through electronic media. As the two examples of SAP and Siemens illustrate, virtual delegates may support this transfer of standardized knowledge. On the other hand they are less efficient when a high degree of explanations and personal trust is needed. For example, it is not possible for them to meet spontaneously and chat with their overseas colleagues on the floor or during lunchtime (Holtbrügge \& Schillo, 2008a). Hence we propose:

Hypothesis 3: The higher the relevance of electronic compared to personal modes of knowledge transfer, the more often virtual delegations are used. 
The research model of our study is illustrated in Figure 3-1.

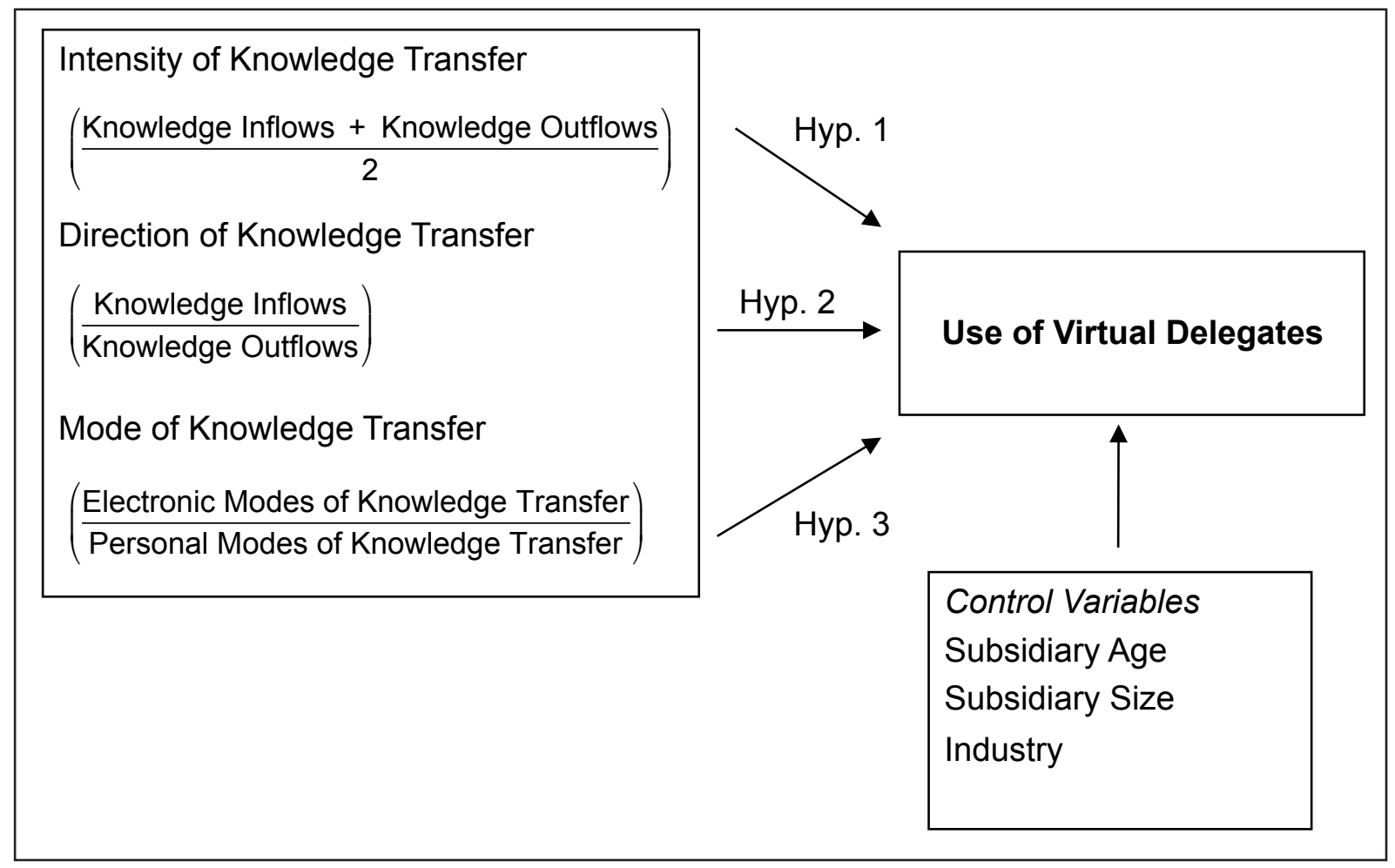

Figure 3-1: $\quad$ Research Model of our Study

\subsection{Methodology}

\subsubsection{Sample}

In order to test these research hypotheses, an empirical study among MNCs in the BRICS countries (Brazil, Russia, India, China and South Africa) was conducted. These countries were selected because they absorb a high degree of foreign direct investment (FDI) (UNCTAD, 2006). Furthermore, many MNCs have established operations in these countries only relatively recently. This allows them to implement the most up-to-date management techniques here. Since virtual assignments are a new phenomenon, they may be expected to be used in the BRICS countries intensively.

We contacted the chambers of foreign trade of the United States of America and of the member countries of the European Union in the BRICS countries and received a large number of contact addresses. All subsidiaries of MNCs headquartered in the U.S. or the EU were contacted via e-mail and asked to participate in the study in January 2007. A link in the e-mail led them to an online questionnaire. On the first page, the concept of virtual delegation and the aims of the study were explained. The individuals who opened the online questionnaire were asked to forward this to the member of the top-management team in their subsidiary who they perceive 
to be best suited to answer questions about this subject.

After four weeks, we sent a reminder to those companies that had not yet answered. Finally, 255 usable questionnaires were received. A test for non-response bias by comparing early and late arriving responses according to Armstrong and Overton (1977) revealed no significant differences for any independent variable, and non-response bias was therefore not considered as a problem.

The geographical distribution of the respondents is presented in Table 2. It shows that the numbers of subsidiaries located in China and India, which are the two countries currently absorbing the largest amount of FDI from Germany, are the highest in our sample. Subsidiaries in South Africa are slightly overrepresented and those in Russia underrepresented in our sample. ANOVA analyses revealed no significant differences concerning the use of virtual assignments between different home and host countries. On average, the subsidiaries employed 1,114 people and are 17.148 years old. $47.8 \%$ of them are manufacturing units, and $52.2 \%$ operate in services and trade.

\begin{tabular}{lcc}
\hline Country & Number & Percentage \\
\hline Brazil & 23 & $9.0 \%$ \\
Russia & 4 & $1.6 \%$ \\
India & 72 & $28.2 \%$ \\
China & 95 & $37.3 \%$ \\
South Africa & 61 & $23.9 \%$ \\
Total & 255 & $100.0 \%$ \\
\hline
\end{tabular}

Table 3-1: Geographical Distribution of the Sample

\subsubsection{Measures}

\subsubsection{Dependent Variables}

Prior to measuring the dependent variable "use of virtual delegates", the concept of virtual delegation was first explained to the respondents. Virtual delegates were defined as "employees located in the headquarters, who are responsible for management and technical tasks in the subsidiary for a period of at least one year and who spend at least 80 percent of their working time for these tasks." Afterwards, the respondents were asked to assess the actual use of virtual delegates in their subsidiary on a 7-point Likert-type scale ranging from 1 = "virtual delegates are not used at all" to 7 = "virtual delegates are used very extensively". This perceptional measure was used because several pilot interviews revealed that respondents in the subsidiary find it very difficult to state the concrete number of virtual delegates who, by definition, are located 
in the headquarters. While actual numbers would be preferential to perceptional measures in terms of validity, the latter are intended to enhance the reliability and the number of responses to this question.

\subsubsection{Independent Variables}

The direction of knowledge transfer was measured according to Gupta and Govindarajan (2000) by asking the respondents "to what extent the subsidiary (i) provides knowledge to the headquarters" and (ii) "receives knowledge from the headquarters". Both variables were measured on 7-point Likert-type scales going from $1=$ "not at all" to 7 = "to a very high extent". A ratio of both items was calculated indicating the relative importance of knowledge inflows compared to knowledge outflows.

The intensity of knowledge transfer was measured with the same items and calculated as the sum of knowledge inflows and knowledge outflows divided by 2 .

The dominant mode of knowledge transfer was measured according to Holtbrügge and Berg (2004) by asking the respondents to indicate the extent to which (i) personal communication (such as face-to-face meetings) and (ii) electronic media (such as the intranet or e-mails) are used. Both variables were measured on 7-point Likert-type scales going from 1 = "not important at all" to $7=$ "very important". A ratio of both items was calculated indicating the relative importance of electronic compared to personal modes of knowledge transfer.

\subsubsection{Control Variables}

Three control variables were included. We controlled for subsidiary age as virtual delegation is a new concept which may be used in younger subsidiaries more intensively than in older ones. Subsidiary age was measured by asking the respondents when their subsidiary was founded. This number was subtracted from 2007 (the year of the study). Besides, we included subsidiary size as smaller subsidiaries may be more innovative (Minbaeva et al., 2003) and may therefore apply new concepts such as virtual delegates earlier than larger ones. We measured size as the number of employees working in the subsidiary. Similarly, industry may have an impact on the use of virtual delegations. To control for possible industry effects, we distinguished between 1 $=$ "service and trade" and $0=$ "manufacturing". These control variables have been widely used in empirical studies of traditional assignments (e.g., Delios \& Björkman, 2000; Harzing, 2001a; Minbaeva et al., 2003) and may be expected to influence the use of virtual assignments as well. 


\subsection{Results and Discussion}

A first important result of our study is that virtual delegates are used in practice. Although the mean of 2.760 is quite low, only $14.5 \%$ of respondents mentioned that virtual delegates are not used in their company at all. Thus, while former conceptual studies point out the advantages of virtual assignments, our study is the first to empirically demonstrate the relevance of this new phenomenon. However, one must take into account that the subsidiaries in our sample are quite large (mean $=1,114$ employees). It has yet to be proven if virtual assignments are used in smaller subsidiaries and in other regions of the world as well.

The means, standard deviations and correlation coefficients of all variables are presented in Table 3-2. It shows that the intensity of knowledge transfer between headquarters and subsidiaries is relatively high (mean $=4.041$ ). The ratio for the direction of knowledge transfer indicates that, on average, subsidiaries receive more knowledge than they provide (mean $=.872$ ). For the mode of knowledge transfer, personal communication is slightly more important than electronic communication $($ mean $=.953)$.

The correlation analysis reveals that there is only one statistically significant relationship between the independent variables (on a very low level of significance), so our results do not warrant concerns about multicollinearity (Hair et al., 1995). The VIFs are between 1.009 and 1.070 and therefore far below the suggested maximum of 10 . The dependent variable "use of virtual delegates" shows highly significant correlations with the intensity and the mode of knowledge transfer, however, no significant correlation with its direction. Additionally, there are no significant correlations between the use of virtual delegates and any of the control variables.

\begin{tabular}{|c|c|c|c|c|c|c|c|c|c|}
\hline & Mean & SD & 1 & 2 & 3 & 4 & 5 & 6 & 7 \\
\hline $\begin{array}{l}1 \text { Use of Virtual } \\
\text { Delegates }\end{array}$ & 2.760 & 1.589 & - & & & & & & \\
\hline $2 \begin{array}{l}\text { Intensity of } \\
\text { Knowledge Transfer }\end{array}$ & 4.041 & 1.577 & $.366^{\star * \star}$ & - & & & & & \\
\hline $3 \begin{array}{l}\text { Direction of } \\
\text { Knowledge Transfer }\end{array}$ & 0.872 & 0.699 & .024 & .058 & - & & & & \\
\hline $4 \begin{array}{l}\text { Mode of } \\
\text { Knowledge Transfer }\end{array}$ & 0.953 & 0.378 & $.136^{*}$ & -.013 & $-.112 \dagger$ & - & & & \\
\hline 5 Subsidiary Age & 17.148 & 21.262 & -.085 & -.041 & $-.112 \dagger$ & .057 & - & & \\
\hline 6 Subsidiary Size & 1,114 & 5,570 & -.042 & .014 & -.005 & -.012 & $.195^{\star \star}$ & - & \\
\hline 7 Industry & 0.522 & 0.501 & -.095 & -.053 & $.171^{* *}$ & .040 & $-.134^{*}$ & -.082 & - \\
\hline
\end{tabular}

Notes $\dagger \mathrm{p}<0.1, * \mathrm{p}<0.05, * * \mathrm{p}<0.01, * * * \mathrm{p}<0.001 ; \mathrm{n}=255$

Table 3-2: $\quad$ Means, Standard Deviations and Correlations 
The results of the regression analysis are reported in Table 3-3. The use of virtual delegates was entered as the dependent variable into three regression models. In the first model, only the control variables were integrated. Model 1 is statistically not significant. In the second model, only the independent variables were integrated, while both control and independent variables were entered into the third model. Model $2\left(\mathrm{~F}=8.098^{* * *}\right)$ and Model $3\left(\mathrm{~F}=4.933^{* * *}\right)$ are both highly significant.

\begin{tabular}{lccc}
\hline & Model 1 & Model 2 & Model 3 \\
\hline Independent Variables & & & $.275^{* * *}$ \\
Intensity of Knowledge Transfer & & .025 & .031 \\
Direction of Knowledge Transfer & & $.146^{*}$ & $.154^{*}$ \\
Mode of Knowledge Transfer & & & \\
& & & \\
Control Variables & & & -.074 \\
Subsidiary Age & -.100 & & -.034 \\
Subsidiary Size & -.027 & & -.081 \\
Industry & -.056 & & .117 \\
& & .095 & .093 \\
$\mathrm{R}^{2}$ & .013 & .083 & .092 \\
Adjusted R & .001 & .082 & $.933^{* * *}$ \\
Change in adjusted $\mathrm{R}^{2}$ & & $8.098^{* * *}$ & \\
$\mathrm{~F}$ & 1.068 & &
\end{tabular}

Notes $\dagger \mathrm{p}<0.1, * \mathrm{p}<0.05, * * \mathrm{p}<0.01, * * * \mathrm{p}<0.001 ; \mathrm{n}=255$

Table 3-3: $\quad$ Regression Analysis on Use of Virtual Delegates

The independent variables accounted for a modest share of the variance in the use of virtual delegates $\left(.013<\mathrm{R}^{2}<.117\right)$. This result is of little concern here, as the main objective of this study is to find out to what extent virtual assignments are associated with knowledge transfers in MNCs and not to analyze what circumstances contribute to the use of virtual assignments in general. The low values of $\mathrm{R}^{2}$ indicate that there are other factors contributing to the use of virtual assignments than knowledge transfers (such as coordination and control motives), as could have been expected.

Hypothesis 1 predicted that virtual delegates are more often used, the higher the intensity of knowledge transfer between the headquarters and the subsidiary is. This is clearly supported by the regression analysis. In both models the regression coefficient is significant to a very high level. Similarly, the correlation between these two variables is highly significant. Thus, hypothesis 1 is supported by our data. 
Hypothesis 2 suggested that virtual delegates are more often used, the higher the relevance of knowledge inflows from subsidiary to headquarters compared to knowledge outflows from headquarters to subsidiary is. Our results do not support this hypothesis. In both models the regression coefficient is not significant. Moreover, the correlation analysis shows no significant correlation between the use of virtual delegates and the direction of knowledge transfer. Thus the direction of knowledge transfer has no impact on the use of virtual delegates. One explanation for this unpredicted result may be that virtual delegates are seen as uncommitted mediators between the headquarters and the subsidiary who do not belong to either side. Therefore, they may not only - as proposed in hypothesis 2 - facilitate the knowledge transfer from the subsidiary to the headquarters and its efficient absorption there but may also support knowledge transfers from the headquarters to subsidiaries.

In hypothesis 3 we proposed that the use of virtual delegates is higher, the higher the ratio of electronic compared to personal modes of knowledge transfer. This is clearly supported by our study. The regression coefficients in both models are significantly positive, although on a medium level only. The correlation analysis shows a similar result. Thus, hypothesis 3 is supported by our data.

As with the correlation analysis, the control variables show no significant coefficients in our regression models. Neither age and size of the subsidiary nor the industry in which it operates are able to explain the use of virtual delegates.

\subsection{Contributions, Limitations and Implications for Future Studies}

The first contribution in line with the goal of our paper is to extend the literature on foreign delegations. Our study is the first to empirically demonstrate the practical relevance of the use of virtual delegates. While several conceptual studies point out the advantages of virtual assignments (e.g., PricewaterhouseCoopers, 2000; Welch et al., 2003) and possible fields of their application (e.g., Holtbrügge \& Schillo, 2008a), this study shed light on the various aspects of conditions under which virtual delegates are used to support the transfer of knowledge within MNCs. With reference to the literature on foreign delegations our study shows that MNCs may not only chose between home-country, host-county and third-country nationals, but do also use new alternatives such as virtual delegations which may overcome the disadvantages of the traditional forms.

Secondly, we analyzed the relationship of virtual delegations to knowledge transfers in MNCs, thus contributing to the literature on intra-organizational knowledge management. In this context, an important theoretical contribution of our study is that it successfully links the knowledge-based view with the use of virtual delegates. Virtual delegations may support the transfer of knowledge within MNCs and can therefore contribute to their competitive advantage. More specifically, the study reveals that this new phenomenon is used more often, the more relevant 
the knowledge transfer between the units of a MNC and the higher the proportion of electronic compared to personal modes of knowledge transfer is. Furthermore, the ambiguous character of virtual delegates - living in one country but working in another - allows them to transfer knowledge between the geographically dispersed units of a MNC regardless of whether they are mainly providers or receivers of knowledge. Thus, the study contributes to our understanding of knowledge transfers within MNCs.

The third contribution offers practical implications for companies that consider the use virtual delegates and point out to several aspects, which they may consider in their decision-making process. In particular, virtual delegates may be used to support the transfer of codified and standardized knowledge by electronic media. Unsurprisingly, companies such as SAP and Siemens already use this new concept where information technologies are very important. The use of electronic modes of knowledge transfer, however, reduces the opportunity of face-to-face contacts with colleagues, customers or suppliers and makes firsthand experiential learning of foreign cultures difficult. For example, it is not possible to meet colleagues and chat with them on the floor or during lunchtime. Owing to the lack of these simple means of communication, there is a greater likelihood of misunderstandings and intercultural management problems. Especially in countries where it is indispensable to build up trust for good interpersonal and work relationships, this may cause serious difficulties. In addition, communication through electronic media becomes more complex due to different communication styles and time zones (Jarvenpaa \& Leidner, 1999). Besides, virtual delegates have to switch continuously between home- and virtual host-country interactions, which may have a negative impact on their work commitment and identification. As a result, the demands on virtual delegates concerning communication and intercultural skills are very high.

A limitation of this study is the geographical distribution of the sample. Only subsidiaries in the BRICS countries with headquarters in the U.S. and the EU were analyzed. The number of respondents from Russia is very low and does therefore not allow us to draw any conclusions about the use of virtual delegates with reference to this country. Although the BRICS countries are of particular importance for FDI, a transfer of the results to other regions may be problematic given the different economic, legal, and political conditions. Therefore, it might be interesting to explore the use of virtual delegates in other, more industrialized regions such as the Triad countries (EU, U.S. and Japan).

Another limitation is that our study does not include any efficiency criteria. The study reveals, from a knowledge-based view, under which conditions virtual assignments are used, but cannot predict whether they are - compared to other instruments - more or less efficient to support the transfer of knowledge within MNCs. An analysis of the efficiency of virtual assignments, however, would require a complex research design with at least two respondents in each company to reduce the problem of common method bias (e.g., Podsakoff et al., 2003). Moreover, the efficiency of virtual assignments may be evaluated differently by the headquarters and the 
subsidiary, making it necessary to include the perceptions of both sides.

A final limitation of our study is the low percentage of variance in the use of virtual delegates which can be explained by our regression models. One reason for this is that we limited our focus to one particular theoretical framework, namely the knowledge-based view. Therefore, future studies should be based on other concepts such as transaction cost economics or agency theory to analyze additional antecedents which may explain the use of virtual delegates in MNCs. 


\section{References}

Adams, G.L. \& Lamont, B.T. (2003): Knowledge Management Systems and Developing Sustainable Competitive Advantage, in: Journal of Knowledge Management, Vol. 7, 2, p. 142151.

Argote, L. \& Ingram, P. (2000): Knowledge Transfer: A Basis for Competitive Advantage in Firms, in: Organizational Behavior \& Human Decision Processes, Vol. 82, 1, p. 150-169.

Armstrong, J.S. \& Overton, T.S. (1977): Estimating Non-Response Bias in Mail Surveys, in: Journal of Marketing Research, Vol. 14, 3, p. 396-402.

Au, K.Y. \& Fukuda, J. (2002): Boundary Spanning Behaviors of Expatriates, in: Journal of World Business, Vol. 37, 4, p. 285-296.

Bartlett, C.A. \& Ghoshal, S. (1987): Managing Across Borders: New Strategic Requirements., in: Sloan Management Review, Vol. 28, Summer, p. 7-17.

Bechthold, G. (2007): Global Optimization of System Availability through Condition Based Monitoring (unpublished presentation). Munich, 9th of November 2007.

Beise, M. (2001): Lead Markets: Country-Specific Success Factors of the Global Diffusion of Innovations (ZEW Economic Studies Vol. 14), Heidelberg/New York: Physica-Verlag.

Björkman, I., Barner-Rasmussen, W. \& Li, L. (2004): Managing Knowledge Transfer in MNCs: The Impact of Headquarters Control Mechanisms, in: Journal of International Business Studies, Vol. 35, 5, p. 443-455.

Bonache, J. \& Brewster, C. (2001): Knowledge Transfer and the Management of Expatriation, in: Thunderbird International Business Review, Vol. 43, 1, p. 145-168.

Caligiuri, P.M. \& Tung, R.L. (1999): Comparing the Success of Male and Female Expatriates from a U.S.-based Multinational Company, in: International Journal of Human Resource Management, Vol. 10, 5, p. 763-782.

Chini, T., Ambos, B. \& Wehle, K. (2005): The Headquarters-subsidiaries Trench: Tracing Perception Gaps Within The Multinational Corporation, in: European Management Journal, Vol. 23, 2, p. 145-153.

Cohen, W.M. \& Levinthal, D.A. (1990): Absorptive Capacity: A new Perspective on Learning and Innovation, in: Administrative Science Quarterly, Vol. 35, 1, p. 128-152.

Collings, D.G., Scullion, H. \& Morley, M.J. (2007): Changing Patterns of Global Staffing in the Multinational Enterprise: Challenges to the Conventional Expatriate Assignment and Emerging Alternatives, in: Journal of World Business, Vol. 42, 2, p. 198-213.

Delios, A. \& Björkman, I. (2000): Expatriate Staffing in Foreign Subsidiaries of Japanese Multinational Corporations in the PRC and the United States, in: International Journal of Human Resource Management, Vol. 11, 2, p. 278-293.

Dowling, P. \& Welch, D. (2004): International Human Resource Management, 4th ed., London: Thomson Publishing.

Downes, M. \& Thomas, A.S. (2000): Knowledge Transfer Through Expatriation: The U-curve Approach to Overseas Staffing, in: Journal of Managerial Issues, Vol. 12, 2, p. 131-151.

Fenwick, M. (2004): On International Assignment. Is Expatriation the Only Way to Go?, in: Asia Pacific Journal of Human Resources, Vol. 42, 3, p. 365-377.

Forsgren, M. \& Hagström, P. (2007): Ignorant and Impatient Internationalization? The Uppsala Model and Internationalization Patterns for Internet-related Firms, in: Critical Perspectives on International Business, Vol. 3, 3, p. 291-305.

Ghoshal, S., Korine, H. \& Szulanski, G. (1994): Interunit Communication in Multinational Corporations, in: Management Science, Vol. 40, 1, p. 96-110.

Grant, R.M. (1996): Toward a Knowledge-based Theory of the Firm, in: Strategic Management Journal, Vol. 17, Special Issue, p. 109-122. 
Gupta, A.K. \& Govindarajan, V. (1991): Knowledge Flows and the Structure of Control within Multinational Corporations, in: Academy of Management Review, Vol. 16, 4, p. 768-792.

Gupta, A.K. \& Govindarajan, V. (2000): Knowledge Flows within Multinational Corporations, in: Strategic Management Journal, Vol. 21, 4, p. 473-496.

Hair, J.F. Jr., Anderson, R.E., Tatham, R.L. \& Black, W.C. (1995): Multivariate Data Analysis, New Jersey: Prentice Hall.

Harris, H., Brewster, C. \& Erten, C (2005): Auslandseinsatz, aber wie?, in: Stahl, G.K., Mayrhofer, W. \& Kühlmann, T.M. (eds): Internationales Personalmanagement, München/ Mering: Hampp, 272-291.

Harzing, A.-W. (1995): The Persistent Myth of High Expatriate Failure Rates, in: International Journal of Human Resource Management, Vol. 6, 2, p. 457-474.

Harzing, A.-W. (2001a): Who's in Charge? An Empirical Study of Executive Staffing Practices in Foreign Subsidiaries, in: Human Resource Management, Vol. 40, 2, p. 139-158.

Harzing, A.-W. (2001b): Of Bears, Bumble-bees, and Spiders. The Role of Expatriates in Controlling Foreign Subsidiaries, in: Journal of World Business, Vol. 36, 4, p. 366-379.

Hedlund, G. \& Nonaka, I. (1993): Models of Knowledge Management in the West and Japan, in: Lorange, P., Chakravarthy, B., Roos, J. \& Van de Ven, A. (eds): Implementing Strategic Process - Change, Learning, and Cooperation, London: Basil Blackwell, p. 117-144.

Holtbrügge, D. \& Berg, N. (2004): Knowledge Management in Multinational Corporations. Results of an Empirical Study among German Firms, in: Management International Review, Vol. 44, Special Issue 3, p. 129-145.

Holtbrügge, D. \& Schillo, K. (2008a): Managing from a Distance: Virtual Delegation to India. In: Hendel, A., Messner, W. \& Thun, F. (eds): Rightshore! Successfully Industrialize SAP® Projects Offshore, Berlin: Springer, p. 121-144.

Holtbrügge, D. \& Schillo, K. (2008b): Intercultural Training Requirements for Virtual Assignments: Results of an Explorative Empirical Study, in: Human Resource Development International, Vol. 11, 3, p. 271-286.

Jarvenpaa, S.L. \& Leidner, D.E. (1999): Communication and Trust in Global Virtual Teams, in: Organization Science, Vol. 10, 6, p. 791-815.

Konopaske, R. \& Werner, S. (2005): US Managers' Willingness to Accept a Global Assignment: Do Expatriate Benefits and Assignment Length make a Difference?, in: International Journal of Human Resource Management, Vol. 16, 7, p. 1159-1175.

Meso, P. \& Smith, R. (2000): A Resource-based View of Organizational Knowledge Management Systems, in: Journal of Knowledge Management, Vol. 4, 3, p. 224-234.

Minbaeva, D.B., Pedersen, T., Björkman, I., Fey, C.F. \& Park, H.J. (2003): MNC Knowledge Transfer, Subsidiary Absorptive Capacity, and HRM, in : Journal of International Business Studies, Vol. 34, 6, p. 586-599.

Minbaeva, D.B. \& Michailova, S. (2004): Knowledge Transfer and Expatriation in Multinational Corporations, in: Employee Relations, Vol. 26, 6, p. 663-679.

Nonaka, I. \& Takeuchi, H. (1995): The Knowledge-creating Company: How Japanese Companies Create the Dynamics of Innovation, Oxford: Oxford University Press.

Pedersen, T., Petersen, B. \& Sharma, D. (2003): Knowledge Transfer Performance of Multinational Companies, in: Management International Review, Vol. 43, Special Issue 3, p. 69-90.

Penrose, E. (1959): The Theory of the Growth of the Firm, London: Basil Blackwell.

Pires, G., Stanton, J. \& Ostenfeld, S. (2006): Improving Expatriate Adjustment and Effectiveness in Ethnically Diverse Countries: Marketing Insights, in: Cross Cultural Management, Vol. 13, 2, p. 156-170. 
Podsakoff, P.M., MacKenzie, S.B., Lee, J.-Y. \& Podsakoff, N.P. (2003): Common Method Biases in Behavioral Research: A Critical Review of the Literature and Recommended Remedies, in: Journal of Applied Psychology, Vol. 88, 5, p. 879-903.

Polanyi, M. (1966): The Tacit Dimension, London: Routledge \& Kegan Paul.

PricewaterhouseCoopers (2000): Managing in a Virtual World. International Non-standard Assignments, Policy and Practice. Europe: PricewaterhouseCoopers.

Purdy, J.M. \& Nye, P. (2000): The Impact of Communication Media on Negotiation Outcomes, in: International Journal of Conflict Management, Vol. 11, 2, p. 162-187.

Tsang, E.W.K. (1999): The Knowledge Transfer and Learning Aspects of International HRM: An Empirical Study of Singapore MNCs, in: International Business Review, Vol. 8, 5/6, p. 591-609.

UNCTAD (2006): World Investment Report 2005, Geneva.

Welch, D.E., Worm, M. \& Fenwick, M. (2003): Are Virtual International Assignments Feasible?, in: Management International Review, Vol. 43, Special Issue 1, p. 95-114. 


\section{Kapitel 4 \\ Remote Control of Foreign Subsidiaries. \\ A Transaction Cost Analysis of Virtual Expatriation., ${ }^{1,2}$}

\section{Contents}

4.1 Problem and Objectives

4.2 Theory and Hypotheses: A Transaction Cost Perspective of Virtual Expatriation

4.2.1 Asset Specificity, Uncertainty, and Frequency

4.2.2 Asset Specificity and the Use of Virtual Expatriates

4.2.3 Uncertainty and the Use of Virtual Expatriates

4.2.4 Frequency and the Use of Virtual Expatriates

4.3 Methodology

4.3.1 Sample

4.3.2 Measures

4.3.2.1 Dependent Variable

4.3.2.2 Independent Variables

4.3.2.3 Control Variables

4.4 Results and Discussion

4.5 Contributions, Limitations and Implications for Future Studies 


\subsection{Problem and Objectives}

The control of subsidiaries is one of the crucial tasks of multinational corporations (MNC) (e.g., Ferner et al., 2004; Gatignon \& Anderson, 1988; Hennart, 1991; Ouchi, 1977). Control refers to the MNC's ability to enforce its various operating units around the world to act in accordance with its overall policy in a systematic and coherent manner (e.g., Paik \& Sohn, 2004). Since the goals of the MNC's headquarters and its local subsidiaries may not necessarily correspond with each other, control ensures that all "parts of the organization are compatible and support common goals" (Egelhoff, 1984, p. 73).

According to transaction cost theory, two forms of control can be distinguished: market and hierarchical control. Market control mechanisms are, for example, internal competition (e.g., Birkinshaw, 2000) and heterarchies (e.g., Hedlund, 1986). The function of the headquarters in this context is to establish the framework for decentralized decision-making and to guarantee that the individual behavior of subsidiaries contributes to the overall objectives of the MNC. In contrast, hierarchical control is characterized by centralized decision-making and by directly influencing subsidiary behavior through technocratic mechanisms such as planning and formalization (Alvesson \& Kärreman, 2004) or through parent-country expatriations (e.g., Delios \& Björkman, 2000; Tan \& Mahoney, 2002).

An advantage of market control mechanisms is that decisions about the content and extent of control are made inside the subsidiary (e.g., Birkinshaw, 2000). This is especially important in countries with a large cultural distance from the home country, as the headquarters may lack a deep understanding of the local conditions. Hence, this adversely affects their ability to make efficient decisions. On the contrary, by using market control mechanisms the headquarters may be concerned about the subsidiary's prior interests in the local business, its opportunistic behavior, and about the MNC's worldwide profitability (e.g., Birkinshaw et al., 2000). This leads to the headquarters' desire for hierarchical control. Technocratic mechanisms, however, may reduce the ability of subsidiaries to adapt themselves to the local conditions (e.g., Doz \& Prahalad, 1988; Gomez-Mejia \& Palich, 1997; Hamilton \& Kashlak, 1999; Holtbrügge, 2005). The delegation of parent-country nationals (expatriates) as a personal form of hierarchical control can also cause opportunistic behavior and agency problems because the expatriates may so strongly identify with the foreign operation ("going native") that they lose sight of headquarters' objectives and the global perspective (e.g., Harzing, 2001b; Tan \& Mahoney, 2006; Welch et al., 2003).

Since traditional forms of hierarchical and market control have several disadvantages, many MNCs are looking for new control mechanisms. In this context, virtual expatriates are used as a way to overcome these deficits and to allow for a more balanced consideration of headquarters' and subsidiaries' interests. Virtual expatriates are characterized by the fact that 'an employee does not relocate to a host location, but has international responsibilities for a part of the organization in another country which they manage from the home country" (Pricewater- 
houseCoopers, 2000, p. 31). Virtual expatriates remain in their home country most of the time, in comparison to expatriates who are delegated abroad. They work in the headquarters and interact mostly with colleagues, customers and suppliers in a foreign country. Hence, virtual expatriates are characterized by the spatial and psychic separation of private and work life. While physically located in the headquarters, from an organizational and operational point of view, they belong to the subsidiary. Thus, they may be interpreted as a form of remote control of foreign subsidiaries (Holtbrügge \& Schillo, 2008a).

Over the last few years several studies of virtual expatriates have been published. For example, Fenwick (2004) analyzes variations of traditional international assignments and shows that virtual expatriates are increasingly used within teams whose members are located in different countries. Their main advantage is to reduce "expensive and risky expatriate postings" (ibid., p. 368). According to PricewaterhouseCoopers (2000), the main reason for the use of virtual expatriations is to attract the best talents available. Virtual expatriations are viewed as a way to meet their demand for advantageous working-conditions because they consider the importance of work-life-balance and reduce the problems of dual-career couples.

Holtbrügge and Schillo (2008b) argue that virtual expatriates may reduce control costs in MNCs and offer new business opportunities. The separation of physical presence and organizational affiliation, which is made possible by the intensive use of electronic media such as e-mails, telephone and video conference or chats, however, requires intensive intercultural and communication training. Welch et al. (2003) analyze the strategic role of virtual expatriates and conclude that they are not only a solution to staff immobility and cost containment, "but a fundamental strategic requirement to facilitate flexible multinational forms" (ibid., 2003, p. 110). Moreover, virtual expatriates can simultaneously achieve headquarters goals, while building and maintaining good relations with various stakeholders in the host location. "This boundary-spanning role assists in transferring information and knowledge about the subsidiary environment to the centre, enhancing global control” (ibid., 2003, p. 103).

While these and other previous studies argue that virtual expatriations may support the remote control of foreign subsidiaries, little is known about the conditions under which they are applied. Therefore, the aim of this paper is to analyze the use of virtual expatriation as a control mechanism in MNCs. We will apply a transaction cost perspective and analyze whether or not the use of virtual expatriation as a control mechanism depends on the level of transaction costs, i.e. the asset specificity, uncertainty and frequency of transactions between the headquarters and the subsidiaries of a MNC.

The paper is organized as follows. In the next section, the transaction cost theory will be applied to virtual expatriations as a control mechanism in MNCs and research hypotheses will be derived. ,The methodology of the study will then be explained, followed by the presentation and discussion of the main results. The paper ends with a summary of its contributions and limitations as well as some suggestions for future research. 


\subsection{Theory and Hypotheses: A Transaction Cost Perspective of Virtual Expatriation}

\subsubsection{Asset Specificity, Uncertainty, and Frequency}

Transaction cost theory is one of the best-established theories and has extensively been used to explain the existence and operations of MNCs (e.g., Buckley \& Casson, 1976; Rugman, 1981). In particular, questions of control in different contexts were analyzed on the basis of transaction cost theory, such as the control of foreign subsidiaries and international joint ventures (e.g., Cleeve, 1997; Erramilli \& Rao, 1993; Gatignon \& Anderson, 1988; Geringer \& Herbert, 1989; Hennart, 1988; Tsang, 2000) or within the analysis of subsidiary control via expatriates (e.g., Harzing, 2001a; Tan \& Mahoney, 2003, 2006). We argue that transaction cost theory is also a reasonable framework to explain the use of virtual expatriates for the control of foreign subsidiaries because it explores the relevance of control mechanisms under different transaction characteristics such as asset specificity, uncertainty, and frequency of transactions. As we will argue later, these factors are also relevant for the use of virtual expatriates. Before developing our research hypothesis, we present the basic arguments of transaction cost theory and adapt these to virtual expatriates.

According to Williamson (1975), transaction cost theory is based on the assumption that transaction costs depend on behavioral and transactional factors. The behavioral factors are explained in the "organizational failure framework", which describes the bounded rationality and opportunism of individuals. Owing to the asymmetrical distribution of information, it is not possible to create perfect contracts, which cover all information. As a matter of fact individuals act in an opportunistic manner to their advantage, which incurs costs. The transactional factors describe the character of the transaction and consist of three dimensions: 1) asset specificity, 2) uncertainty and 3) frequency. The combination of behavioral and transactional factors defines the amount of transaction costs. Transaction cost theory offers two choices to deal with transaction costs; using the market or using the hierarchy. Hierarchical modes of transaction may be used when their costs are lower than the cost of using the market (e.g., Coase, 1937). "The main differences between market and internal organization [hierarchy] are these: (1) Market promote high-powered incentives and restrain bureaucratic distortions more effectively than internal organization; (2) markets can sometimes aggregate demands to advantage, thereby to realize economies of scale and scope; and (3) internal organization has access to distinctive governance instruments" (Williamson, 1985, p. 90).

Transaction cost theory argues that the choice between hierarchy and market depends on three criteria, namely asset specificity, uncertainty and frequency of transactions. Four types of asset specificity are distinguished; site specificity, physical asset specificity, human asset specificity, and dedicated assets (e.g., Williamson, 1985). Specific assets "are those whose value in its pres- 
ent use is higher than the value they would have in any alternative use" (Klein et al., 1978 cited in Bonache Pérez \& Pla-Barber, 2005, p. 1322). Referring to the idea that assets are intended for a specific context, an increase of asset specificity incurs an increasing dependency (idiosyncrasy) between the parties of transaction. Likewise opportunistic behavior and sunk costs are rising (Monteverde \& Teece, 1982). This increase of asset specificity incurs transaction costs and, therefore, the likelihood of internalization of transactions is rising (e.g., Teece, 1986; Williamson, 1985).

The second transactional factor which relates to the choice between market and hierarchy is uncertainty. "The basic proposition here is that governance structures differ in their capacities to respond effectively to disturbances" (Williamson, 1985). Uncertainty arises because of bounded rationality and opportunistic behavior of individuals. With the absence of bounded rationality it would be possible to develop perfect contracts, which cover all eventualities in the future (e.g., Williamson, 1985). Because of their imperfection, contracts continuously have to be adapted. For transactions with high uncertainty it is more difficult to cover the complexity of potential future developments within the contract. As a consequence, the scope of opportunism for the transaction partners is wider. The increase of uncertainty entails transaction costs and therefore, the likelihood of internalization of transaction is rising. Uncertainty can arise from internal and external factors (e.g., Williamson, 1981). Internal uncertainty covers hidden and invisible processes within the organization. External uncertainty is related to risks, which cannot be influenced by the organization. In an international context external uncertainties are "generally understood to mean the extent to which a country's political, legal, cultural, and economic environment threatens the stability of a business operation" (Gatignon \& Anderson, 1988, p. 315).

The third transactional factor is frequency. The frequency of transactions determines the point of amortization of hierarchical control mechanisms and relates to economies of scale (e.g., Williamson, 1985). Economies of scale occur when the average costs of goods or services decrease as the volume of production increases (e.g., Collis \& Montgomery, 1997). This argument can also be applied to control mechanisms. Control mechanisms which are used more frequently may cause lower average transaction costs per transaction, i.e. frequent transactions justify hierarchical control mechanisms because they allow a firm to exploit economies of scale. On the contrary, incidental transactions should be handled through the market.

\subsubsection{Asset Specificity and the Use of Virtual Expatriates}

As mentioned above, specific assets "are those whose value in its present use is higher than the value they would have in any alternative use" (Klein et al., 1978). Subsidiaries with a high level of asset specificity own special capabilities on technological or managerial knowledge (e.g., Williamson, 1983). As these assets are intended for a specific context, an increase of asset specificity leads to an increasing dependency (idiosyncrasy) between the headquarters and 
the subsidiary. Consequently, subsidiaries with a high level of asset specificity are of particular importance for the headquarters to contribute to the overall goals. Likewise the dangers of opportunistic behavior of the subsidiary and the sunk costs are rising (e.g., Monteverde \& Teece, 1982). Asset specificity thus incurs transaction costs and, therefore, the likelihood of internalization and centralization of subsidiary control within the headquarters is rising (e.g., Teece, 1986; Williamson, 1985).

Virtual expatriations are believed to be an efficient control mechanism in the case of high asset specificity for several reasons. The boundary-spanning role of virtual expatriates enables them to consider the goals of both the headquarters and the subsidiary simultaneously. Moreover, the permanent interaction with individuals in the headquarters and in the subsidiary makes them aware of the high degree of dependency between the two. Thus, they are likely to make decisions that reduce the subsidiary's ability for opportunistic behavior and the sunk costs which are associated with high asset specificity. Based on this argumentation, we derive the following hypothesis:

\section{Hypothesis 1: The higher the level of asset specificity of a subsidiary, the more in-} tense is the use of virtual expatriates as control mechanism.

\subsubsection{Uncertainty and the Use of Virtual Expatriates}

Uncertainty refers to the fact that the future is not totally predictable and that perfect contracts cannot be developed. Two forms of uncertainty can be distinguished. From the headquarters' perspective, internal uncertainty covers hidden and invisible processes within the subsidiary (e.g., the adherence of quality standards). The geographical and cultural distance between headquarters and subsidiary makes it difficult to predict its behavior. Similarly, the subsidiary perceives uncertainty about future decisions of the headquarters. In this context, virtual expatriations may reduce uncertainty on both sides. Their boundary-spanning role enables them to inform the headquarters about future plans of the subsidiary and vice versa. This knowledge and familiarity of both the headquarters and the subsidiary is more important, the higher the uncertainty is. This leads to the following hypothesis:

\section{Hypothesis 2a: The higher the internal uncertainty pertains to a subsidiary, the more intense is the use of virtual expatriates as control mechanism.}

External uncertainty characterizes the development of the subsidiary's environment (e.g., stability of the market, politics or currency). For the headquarters, the environmental conditions under which the subsidiary operates are more difficult to predict and to evaluate than for the subsidiary itself. This information asymmetry, which is a result of the geographic and cultural distance between the two, increases the subsidiary's scope for opportunistic behavior. For ex- 
ample, the subsidiary may negotiate turnover objectives with the headquarters which are far below the level that could be achieved.

We argue that virtual expatriations may be an efficient mechanism to reduce external uncertainty. Virtual expatriates interact regularly with individuals in the subsidiary as well as with its customers, suppliers and other stakeholders and are therefore best suited to develop a realistic view of the conditions under which the subsidiary operates. At the same time their physical location in the headquarters allows them to transfer this local knowledge to the headquarters and to reduce the external uncertainty there. Thus the following hypothesis can be derived:

\section{Hypothesis 2b: The higher the external uncertainty pertains to a subsidiary, the more intense is the use of virtual expatriates as control mechanism.}

\subsubsection{Frequency and the Use of Virtual Expatriates}

The frequency of transactions between headquarters and subsidiary refers to the potential to exploit economies of scale. In line with transaction cost theory it could be argued that virtual expatriations will be used particularly in cases of frequent transactions between the two because they cause high fixed costs. For example, guidelines for their use must be developed, their duties and rights must be fixed, and virtual expatriations must be integrated into the organizational frameworks of the headquarters. Moreover, intensive intercultural training is needed (Holtbrügge \& Schillo, 2008b). These expenses can be amortized quickly if the virtual delegate interacts frequently with the subsidiary. Based on these considerations we propose:

\section{Hypothesis 3: The higher the frequency of transactions between headquarters and subsidiary, the more intense is the use of virtual expatriates as control mechanism.}

The summary of the three hypotheses which have been developed in the previous paragraph lead to our research model which is presented in Figure 4-1. 


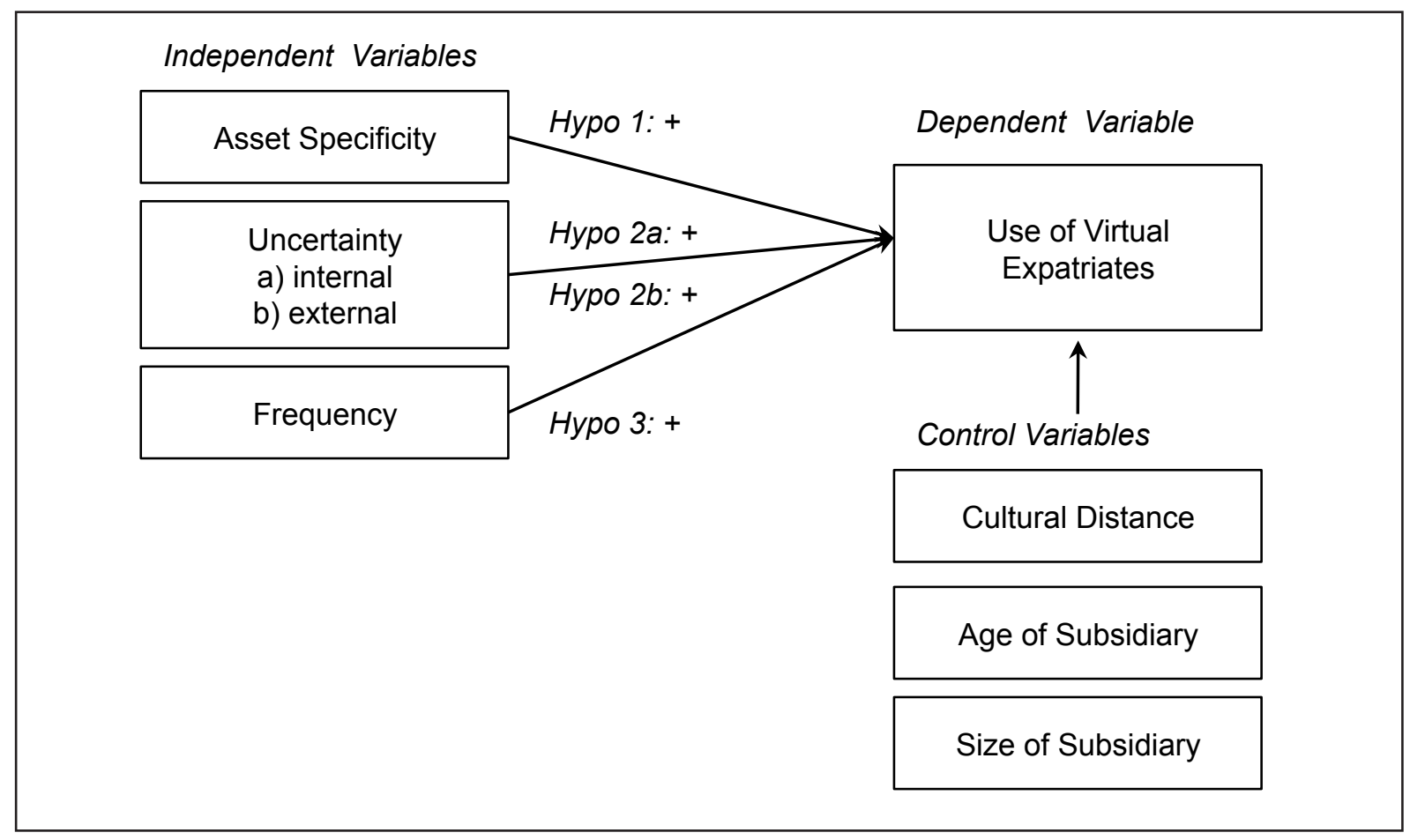

Figure 4-1: $\quad$ Research Model

\subsection{Methodology}

\subsubsection{Sample}

In order to test the research hypotheses developed in the last paragraph, an empirical study among MNCs in the BRICS countries (Brazil, Russia, India, China and South Africa) was conducted. These countries were selected because they absorb a high degree of foreign direct investment (FDI) (UNCTAD, 2008). Moreover, many MNCs have established operations in these countries only in the last few years. This allows them to implement the most recent control mechanisms in these new markets. Since virtual expatriations are a very innovative phenomenon, they may be expected to be particularly relevant in the BRICS countries.

We contacted the chambers of foreign trade of the United States of America and of the member countries of the European Union in the BRICS countries and were able to attain a large number of contact addresses. In January 2007, all subsidiaries of MNCs headquartered in the U.S. or the EU were contacted via e-mail and asked to participate in our study. A link in the e-mail led to an online questionnaire. On the first page, the concept of virtual expatriation and the aims of the study were explained. The individuals who opened the online questionnaire were asked to forward it to a member of the top-management team in their subsidiary who they perceived to be suitable to answer questions about this subject.

After four weeks, we sent a reminder to those companies that had not responded. Finally, 172 applicable questionnaires were received. A test for non-response bias by comparing early and 
late responses according to Armstrong and Overton (1977) revealed no significant differences for any independent variable. Non-response bias was, therefore, not considered to be a problem. The geographical distribution of the respondents is presented in Table 1. It shows that the numbers of subsidiaries located in China, which is the country absorbing the largest amount of FDIs from Germany at the moment, is the highest in our sample. Compared to actual FDI outflows of German MNCs, subsidiaries in South Africa are slightly over-represented and those in Russia are highly under-represented. ANOVA analyses revealed no significant differences concerning the use of virtual expatriations between different home and host countries. On average, the 172 subsidiaries employed 1,177 people and are 16.95 years old. $52.3 \%$ of them are manufacturing units, and $47.7 \%$ operate in services and trade.

\begin{tabular}{|l|c|c|}
\hline Country & Number & Percentage \\
\hline Brazil & 19 & $11.0 \%$ \\
\hline Russia & 4 & $2.3 \%$ \\
\hline India & 30 & $17.4 \%$ \\
\hline China & 84 & $48.8 \%$ \\
\hline South Africa & 35 & $20.3 \%$ \\
\hline Total & 172 & $100.0 \%$ \\
\hline
\end{tabular}

Table 4-1: Geographical Distribution of the Sample

\subsubsection{Measures}

\subsubsection{Dependent Variable}

In the first part of the questionnaire the concept of virtual expatriation was explained to the respondents. Virtual expatriates were defined as "employees located in the headquarters, who are responsible for management and technical tasks in the subsidiary for a period of at least one year and who spend at least 80 percent of their working time for these tasks." Afterwards, the respondents were asked to assess the use of virtual expatriates on a seven-point Likert-type scale ranging from 1 = "virtual expatriates will not be used at all" to 7 = "virtual expatriates will be used very extensively". This perceptional measure was used because several pilot interviews revealed that respondents in the subsidiary find it very difficult to state the concrete number of virtual delegates who, by definition, are located in the headquarters. While actual numbers would be preferential to perceptional measures in terms of validity, the latter are intended to enhance the reliability and the number of responses to this question. 


\subsubsection{Independent Variables}

For measuring the asset specificity of the subsidiary we deployed two items recommended by Brouthers and Brouthers (2003). The respondents were asked to assess the technological resources and the creative potential of the subsidiary by the following two questions: "How many technological resources (for example technological know-how, patents, copyrights) does your firm have to handle international expansion?" and "How do you rate your firm's potential to create new and creative products or services?" Both items were measured on seven-point Likerttype scales starting from 1 = "few resources"/"few potential" to 7 = "many resources"/"very high potential"'.

Internal uncertainty was measured with two items developed by Agarwal and Ramaswami (1992) by asking the respondents "What do you think about the following aspects in your host country" (i) "cost of making and enforcing contracts" and (ii) "observance of the company wide quality standards of products and services." Both items were measured on seven-point Likerttype scales going from 1 = "very low" to 7 = "very high".

Similarly, in line with Agarwal and Ramaswami (1992) we measured external uncertainty with two items by asking "What do you think about the following aspects in your host country (i) general stability of the political, social and economic conditions" and (ii) "price level and currency stability." Both items were also measured on seven-point Likert-type scales going from 1 $=$ "very high" to 7 = "very low".

For the frequency of transactions, we asked the respondents to assess the intensity of knowledge transfers between headquarters and subsidiary. We used this item as a proxy because a high intensity of knowledge transfer requires a high frequency of interaction and may lead to a high demand of control. The intensity of knowledge transfer was measured by asking the respondents "To what extent is your subsidiary engaged in the transfer of knowledge and skills?" on a seven-point Likert-type scale ranging from 1 = "not at all" to 7 = "on a very high extent".

\subsubsection{Control Variables}

Three control variables were included. We used cultural distance between the home and the host country because subsidiaries with a high cultural distance have been argued to have a higher demand of control through employees of the headquarters (Boyacigiller, 1990; Harzing, 2001a). We measured cultural distance by using the index of Kogut and Singh (1988), which is based on the four dimensions of culture developed by Hofstede $(1980,2001)$. We controlled for subsidiary age, since virtual expatriation is a relatively new concept which may be used in younger subsidiaries more intensively than in older ones (Tan \& Mahoney, 2002). Subsidiary age was measured by asking the respondents about the founding year of the subsidiary. This number was subtracted from 2007 (the year of the study). We included subsidiary size since smaller subsidiaries may be more innovative than larger ones (Minbaeva et al., 2003) and may, therefore, apply new concepts earlier than their counterparts. We measured this variable by 
the number of employees working in the subsidiary. These control variables have been widely used in empirical studies of traditional expatriations (e.g., Delios \& Björkman, 2000; Gupta \& Govindarajan, 2000; Harzing, 2001a; Minbaeva et al., 2003; Tan \& Manhoney, 2002, 2006) and may be expected to influence the use of virtual expatriations as well.

All multi-item variables in our study showed an acceptable internal reliability. To reduce common-method bias, we separated items measuring the same construct in the online-questionnaire and assured respondent anonymity (e.g., Podsakoff et al., 2003).

\subsection{Results and Discussion}

Table 4-2 presents the means, standard deviations and correlation coefficients of all variables in the study. Although it reveals a rather low mean for the use of virtual expatriations of 2.700 , only $15.1 \%$ of the respondents mentioned that they are not used in their subsidiary at all. Thus, the general relevance of this mechanism of remote control is supported by our study.

The dependent variable "use of virtual expatriates" shows significant correlations with asset specificity and frequency. No significant correlation with internal and external uncertainty is observed. Among all control variables, only subsidiary age reveals a significant negative correlation with the use of virtual expatriation. The test of multicollinearity shows that the smallest tolerance value is 0.868 and the highest variance inflation factor (VIF) is 1.152, so our results do not warrant concerns about multicollinearity (Hair et al., 1995).

\begin{tabular}{|c|c|c|c|c|c|c|c|c|c|c|}
\hline & Mean & SD & 1 & 2 & 3 & 4 & 5 & 6 & 7 & 8 \\
\hline $\begin{array}{l}1 \text { Use of Virtual } \\
\text { Expatriation }\end{array}$ & 2.700 & 1.368 & - & & & & & & & \\
\hline 2 Asset Specificity & 4.916 & 1.338 & $.152 \dagger$ & - & & & & & & \\
\hline 3 Internal Uncertainty & 4.432 & 1.257 & .123 & .025 & - & & & & & \\
\hline $4 \begin{array}{l}\text { External } \\
\text { Uncertainty }\end{array}$ & 3.310 & 1.095 & .032 & -.096 & -.110 & - & & & & \\
\hline 5 Frequency & 4.190 & 1.326 & $.216^{\star *}$ & $.144 \dagger$ & .040 & -.091 & - & & & \\
\hline 6 Cultural Distance & 2.060 & 1.092 & .039 & $-.193^{*}$ & .113 & .019 & $.151 \dagger$ & - & & \\
\hline 7 Subsidiary Age & 16.95 & 21.12 & $-.136 \dagger$ & .110 & -.044 & -.017 & -.088 & $-.279^{\star \star \star}$ & - & \\
\hline 8 Subsidiary Size & 1,177 & 5,469 & -.126 & .101 & $-.176^{*}$ & -.013 & .025 & .003 & $.238^{* *}$ & - \\
\hline
\end{tabular}

Notes $\dagger \mathrm{p}<0.1, * \mathrm{p}<0.05, * * \mathrm{p}<0.01, * * * \mathrm{p}<0.001 ; \mathrm{n}=172$

Table 4-2: $\quad$ Means, Standard Deviations and Correlations 
The results of the regression analysis with the use of virtual expatriations as the dependent variable in all three regression models are reported in Table 4-3. In the first model, only the control variables were integrated. According to our results, model 1 is statistically not significant. In the second model, only the independent variables were integrated, while all variables were included in the third model. Model $2\left(\mathrm{~F}=2.927^{*}\right)$ and Model $3\left(\mathrm{~F}=2.171^{*}\right)$ are both moderately significant.

\begin{tabular}{lccc}
\hline & Model 1 & Model 2 & Model 3 \\
\hline Independent Variables & & & \\
Asset Specificity & & $0.139 \dagger$ & $0.152 \dagger$ \\
Internal Uncertainty & & 0.117 & 0.080 \\
External Uncertainty & & 0.064 & 0.095 \\
Frequency & & $0.194^{*}$ & $0.196^{*}$ \\
& & & \\
Control Variables & & & \\
Cultural Distance & 0.003 & & -0.006 \\
Subsidiary Age & -0.102 & & -0.069 \\
Subsidiary Size & -0.104 & & -0.114 \\
& & & \\
$\mathrm{R}^{2}$ & 0.026 & 0.077 & 0.104 \\
Adjusted $\mathrm{R}^{2}$ & 0.007 & 0.051 & 0.056 \\
Change in adjusted $\mathrm{R}^{2}$ & & 0.044 & 0.049 \\
$\mathrm{~F}$ & 1.351 & $2.927^{*}$ & $2.171^{*}$ \\
\hline Notes ${ }^{\dagger} \mathrm{p}<0.1 ;{ }^{*} \mathrm{p}<0.05 ; \mathrm{n}=172$ & & &
\end{tabular}

Table 4-3: $\quad$ Regression Analysis

The independent and control variables can explain only a low share of the variance of the dependent variable $\left(0.007<\mathrm{R}^{2}<0.056\right)$. The low values of $\mathrm{R}^{2}$ indicate that there are other factors contributing to the use of virtual expatriations. Since it was the aim of this study to investigate the relationship between transaction costs and virtual expatriations rather than finding a set of variables that fully explains the use of this control mechanism the relative low $\mathrm{R}^{2}$-values are acceptable.

Hypothesis 1 predicted that an increase in the use of virtual expatriates follows a higher level of asset specificity in the subsidiary. In the second and third model, the respective regression coefficients are positive and significant, although on a low level. Likewise, the correlation coefficient between the two variables is significant. Thus, hypothesis 1 is supported by our data.

Hypothesis 2 suggested that a higher level of internal and external uncertainty leads to a more intensive use of virtual expatriates. This hypothesis is not supported by the regression analysis. In both models the regression coefficients are positive, however not significant. Furthermore, the correlation analysis shows no significant result between the use of virtual expatriates and in- 
ternal or external uncertainty. Thus the level of internal and external uncertainty has no impact on the use of virtual expatriates. An explanation for this result may be that virtual expatriates are not seen as an efficient control mechanism under uncertain conditions and that headquarters rely more on traditional mechanisms of hierarchical control such as technocratic instruments or the delegation of home-country nationals. Thus, it would be interesting to replicate this study in some years and to analyze whether MNCs use virtual expatriations in situations of high internal and external uncertainty after they have made more experiences with this mechanism of remote control of foreign subsidiaries.

In hypothesis 3 we proposed that the frequency of transactions between headquarters and subsidiary impacts the use of virtual expatriates as control mechanism. This is clearly supported by the regression analysis. In both models the regression coefficients are moderately significant. The correlation between the two variables is positive and highly significant, too. Thus, hypothesis 3 is supported by our data.

The control variables show no significant results in both the correlation and the regression analyses. Hence, neither the cultural distance between headquarters and subsidiary nor subsidiary age or size can explain the use of virtual expatriation as control mechanisms.

\subsection{Contributions, Limitations and Implications for Future Studies}

This study is one of the first that empirically analyzes the use of virtual expatriates. While previous conceptual studies outline the advantages of virtual assignments, their possible fields of application, and their implications for intercultural training, our study delivers empirical evidence on virtual expatriations as a control mechanism in MNCs. In particular, we were able to show in a large sample of subsidiaries of European and U.S.-American MNCs that their use depends on the transaction costs between headquarters and subsidiaries, i.e., the asset specificity of a subsidiary and the frequency of transactions.

The main theoretical contribution of the study is the application of transaction cost theory to virtual expatriations. While the literature on international human resource management (IHRM) in general and on international assignments in particular is often characterized by a lack of theoretical foundation, we adapted transaction cost theory and demonstrated its usefulness to analyze a relatively new phenomenon in IHRM. Moreover, we combined virtual expatriations with the aspect of control in MNCs, thus contributing to the literature in this field.

From a practitioner's point of view we were able to shed light on the conditions under which virtual expatriations are used in MNCs. Headquarters managers who are responsible for the control of foreign subsidiaries might evaluate these conditions in their own MNC and also consider the use of virtual expatriations as a mechanism of remote control. Thus, this study offers managers an alternative to traditional control mechanisms and allows them to reflect on the application of virtual expatriations in a systematic way. 
A limitation of the study is the geographical scope of our sample. We exclusively analyzed subsidiaries located in the BRICS countries. Because these emerging markets are characterized by rather unique economic, legal and market conditions, a transfer of the results to other countries is difficult. Thus, future studies should focus on other countries and test the influence of different home and host countries on the use of virtual expatriation.

Another limitation of our study is the low percentage of variance in the use of virtual expatriates that can be explained by our independent variables. One reason for this is that we limited our focus to one particular theoretical framework, namely transaction cost theory. This theory has several shortcomings such as the consideration of transactions as independent events and a very narrow perspective of decision-making (e.g., Ghoshal, 2005) that should be born in mind when the results of this study are interpreted. Furthermore, it is plausible that virtual expatriations are used for other than for control reasons, for example, to develop new business opportunities or to offer qualified employees attractive jobs. Therefore, a pluralistic approach to understand the phenomenon of virtual expatriations is needed.

Finally, we were able to show under which conditions virtual expatriations are used, but not whether their use is effective or not. This would require a mirror-image research design where managers in the headquarters are asked to evaluate expected and realized results. Moreover, a normative amplification of transaction cost theory would be needed for the theoretical foundation of such studies. 


\section{References}

Agarwal, S. \& Ramaswami, S.N. (1992): Choice of Foreign Market Entry Mode: Impact of Ownership Location and Internalization Factors, in: Journal of international Business Studies, Vol. 23, 1, p. 1-27.

Alvesson, M. \& Kärreman, D. (2004): Interfaces of Control. Technocratic and Socio-ideological Control in a Global Management Consultancy Firm, in: Accounting, Organizations and Society, Vol. 29, 3/4, p. 423-444.

Armstrong, J.S. \& Overton, T.S. (1977): Estimating Non-Response Bias in Mail Surveys, in: Journal of Marketing Research, Vol. 14, 3, p. 396-402.

Birkinshaw, J. (2000): Entrepreneurship in the Global Firm, London/Thousand Oaks/New Delhi: Sage Publications.

Birkinshaw, J., Holm, U., Thilenius, P. \& Arvidsson, N. (2000): Consequences of Perception Gaps in the Headquarters-subsidiary Relationship, in: International Business Review, Vol. 9, 3, p. 321-344.

Bonache Péreza, J. \& Pla-Barberb, J. (2005): When are International Managers a Cost Effective Solution? The Rationale of Transaction Cost Economics applied to Staffing Decisions in MNCs, in: Journal of Business Research, Vol. 58, 10, p. 1320-1329.

Boyacigiller, N. (1990): The Role of Expatriates in the Management of Interdependence, Complexity and Risk in Multinational Corporations, in: Journal of International Business Studies, Vol. 21, 3, p. 357-381.

Brouthers, K.D. \& Brouthers, L.E. (2003): Why Service and Manufacturing Entry Mode Choice Differ: The Influence of Transaction Cost Factors, Risk and Trust, in: Journal of Management Studies, Vol. 40, 5, p. 1179-1204.

Buckley, P.J. \& Casson, M.C. (1976): The Future of the Multinational Enterprise, London: Macmillan.

Cleeve, E. (1997): The Motives for Joint Ventures: A Transaction Costs Analysis of Japanese MNEs in the UK, in: Scottish Journal of Political Economy, Vol. 44, 1, p. 31-43.

Coase, R.H. (1937): The Nature of the Firm, in: Economica, Vol. 4, Nov., p. 386-405.

Collis, D.J. \& Montgomery, C.A. (1997): Corporate Strategy: Resources and the Scope of the Firm, Burr Ridge: Irwin.

Delios, A. \& Björkman, I. (2000): Expatriate Staffing in Foreign Subsidiaries of Japanese Multinational Corporations in the PRC and the United States, in: International Journal of Human Resource Management, Vol. 11, 2, p. 278-293.

Doz, Y. \& Prahalad, C.K. (1988): Patterns for Strategic Control with Multinational Corporations, in: Journal of International Business Studies, Vol. 15, 2, p. 55-72.

Egelhoff, W. (1984): Patterns of Control in U.S., U.K. and European Multinational Corporations, in: Journal of International Business Studies, Vol. 15, 2, p. 73-83.

Erramilli, M.K. \& Rao, C.P. (1993): Service Firms' International Entry-mode Choice: A Modified Transaction-cost Analysis Approach, in: Journal of Marketing, Vol. 57, 3, p. 19-38.

Fenwick, M. (2004): On International Assignment. Is Expatriation the Only Way to Go?, in: Asia Pacific Journal of Human Resources, Vol. 42, 3, p. 365-377.

Ferner, A., Almond, P., Clark, I., Colling, T., Edwards, T., Holden, L. \& Muller-Camen. M. (2004): Dynamics of Central Control and Subsidiary Autonomy in the Management of Human Resources: Case-Study Evidence from US MNCs in the UK, in: Organization Studies, Vol. 25, 3, p. 363-391.

Gatignon, H. \& Anderson, A. (1988): Multinational Corporation's Control over Subsidiaries, in: Journal of Law, Economics, and Organization, Vol. 4, 2, p. 305-336. 
Geringer, M.J. \& Hebert, L. (1989): Control and Performance of International Joint Ventures, in: Journal of International Business Studies, Vol. 20, 2, p. 235-254.

Ghoshal, S. (2005): Bad Management Theories are Destroying Good Management Practices, in: Academy of Management Learning \& Education, Vol. 4, 1, p. 75-91.

Gomez-Mejia, L. \& Palich, L. (1997): Cultural Diversity and the Performance of Multinational Firms, in: Journal of International Business Studies, Vol. 28, 2, p. 309-335.

Gupta, A.K. \& Govindarajan, V. (2000): Knowledge Flows within Multinational Corporations, in: Strategic Management Journal, Vol. 21, 4, p. 473-496.

Hair, J.F. Jr., Anderson, R.E., Tatham, R.L. \& Black, W.C. (1995): Multivariate Data Analysis, New Jersey: Prentice Hall.

Hamilton, R. \& Kashlak, R. (1999): National Influences on Multinational Control System Selection, in: Management International Review, Vol. 39, 2, p. 167-189.

Harzing, A.-W. (2001a): Who's in Charge? An Empirical Study of Executive Staffing Practices in Foreign Subsidiaries, in: Human Resource Management, Vol. 40, 2, p. 139-158.

Harzing, A.-W. (2001b): Of Bears, Bumble-bees, and Spiders. The Role of Expatriates in Controlling Foreign Subsidiaries, in: Journal of World Business, Vol. 36, 4, p. 366-379.

Hedlund, G. (1986): The Hypermodern MNC - A Heterarchy?, in: Human Resource Management, Vol. 25, 1, p. 9-35.

Hennart J.-F. (1991): Control in Multinational Firms: The Role of Price and Hierarchy, in: Management International Review, Vol.31, Special Issue, p. 71-96.

Hennart J.-F. (1988): A Transaction Costs Theory of Equity Joint Ventures, in: Strategic Management Journal, Vol. 9, 4, p. 361-374.

Hofstede, G. (2001): Culture's Consequences. Comparing Values, Behaviors, Institutions, and Organizations across Nations, 2nd ed., Thousand Oaks/London/New Delhi: Sage Publications.

Hofstede, G. (1980): Culture's Consequences. International Differences in Work-related Values, Newbury Park/London/New Delhi: Sage Publications.

Holtbrügge, D. (2005): Configuration and Co-ordination of Value Activities in German Multinational Corporations. in: European Management Journal, Vol. 23, 5, p. 564-575.

Holtbrügge, D. \& Schillo, K. (2008a): Managing from a Distance: Virtual Delegation to India, in: Hendel, A., Messner, W. \& Thun, F. (eds.): Rightshore! Successfully Industrialize SAP ${ }^{\circledR}$ Projects Offshore, Berlin: Springer, 121-144.

Holtbrügge, D. \& Schillo, K. (2008b): Intercultural Training Requirements for Virtual Assignments: Results of an Explorative Empirical Study, in: Human Resource Development International, Vol. 11, 3, p. 271-286.

Klein B., Crawford R.A. \& Alchian A.A. (1978): Vertical Integration, Appropriable Rents, and the Competitive Contracting Process, in: Journal of Law and Economics, Vol. 21, 2, p. 297-326.

Kogut, B. \& Singh, H. (1988): The Effect of National Culture on the Choice of Entry Mode, in: Journal of International Business Studies, Vol. 19, 3, p. 411-432.

Minbaeva, D.B., Pedersen, T., Björkman, I., Fey, C.F. \& Park, H.J. (2003): MNC Knowledge Transfer, Subsidiary Absorptive Capacity, and HRM, in: Journal of International Business Studies, Vol. 34, 6, p. 586-599.

Monteverde, K. \& Teece, D.J. (1982): Appropriable Rents and Quasi-vertical Integration, in: Journal of Law and Economics, Vol. 25, 2, p. 321-328.

Ouchi, W.G. (1977): The Relationship between Organizational Structure and Organizational Control, in: Administrative Science Quarterly, Vol. 22, 1, p. 95-113. 
Paik, Y. \& Sohn, J.D. (2004): Expatriate Managers and MNC's Ability to Control International Subsidiaries: The Case of Japanese MNCs, in: Journal of World Business, Vol. 39, 1, p. 61-71.

Podsakoff, P.M., MacKenzie, S.B., Lee, J.-Y. \& Podsakoff, N.P. (2003): Common Method Biases in Behavioral Research: A Critical Review of the Literature and Recommended Remedies, in: Journal of Applied Psychology, Vol. 88, 5, p. 879-903.

PricewaterhouseCoopers (2000): Managing in a Virtual World. International Non-standard Assignments, Policy and Practice, Europe: PricewaterhouseCoopers.

Rugman, A.M. (1981): Inside the Multinationals. The Economics of Internal Markets, London: Croom Helm.

Tan, D. \& Mahoney, J.T. (2006): Why a Multinational Firm Chooses Expatriates: Integrating Resource-Based, Agency and Transaction Costs Perspectives, in: Journal of Management Studies, Vol. 43, 3, p. 457-484.

Tan, D. \& Mahoney, J.T. (2003): Explaining the Utilization of Managerial Expatriates from the Perspectives of Resource-based, Agency, and Transaction-costs Theories, in: Advances in International Management, Vol. 15, 179-205.

Tan, D. \& Mahoney, J.T. (2002). An Empirical Investigation of Expatriate Utilization: Re-sourcebased, Agency, and Transaction Costs Perspectives, Working Paper, University of Illinois at Urbana-Champaign, URL: http://www.business.uiuc.edu/Working_Papers/papers/02-0129. pdf.

Teece, D.J. (1986): Transaction Cost Economics and the Multinational Enterprise: An Assessment, in: Journal of Economic Behavior and Organization, Vol. 7, 1, p. 21-45.

Tsang, E.W.K. (2000): Transaction Cost and Resource-based Explanations of Joint Ventures: A Comparison and Synthesis, in: Organization Studies, Vol. 21, 1, p. 215-242.

UNCTAD (2008): World Investment Report 2008. Transnational corporations, and the Infrastructure Challenge, Geneva.

Welch, D.E., Worm, M. \& Fenwick, M. (2003): Are Virtual International Assignments Feasible?, in: Management International Review, Vol. 43, Special Issue 1, p. 95-114.

Williamson, O.E. (1985): The economic institutions of capitalism, New York: Free Press.

Williamson, O.E. (1983): Credible Commitments: Using Hostage to Support Exchange, in: American Economic Review, Vol. 73, 4, p. 519-540.

Williamson, O.E. (1981): The Economics of the Organization: The Transaction-Cost Approach, in: American Journal of Sociology, Vol. 87, 3, p. 548-577.

Williamson, O.E. (1975): Markets and Hierarchies. Analysis and Antitrust Implications, New York/London: Free Press. 



\section{Kapitel 5 \\ Remote Services in Softwareunternehmungen. Das Beispiel SAP. ${ }^{1,2}$}

\section{Gliederung}

5.1 Problemstellung, Zielsetzung und Aufbau des Beitrages

5.2 Struktur des IT-Marktes

5.3 SAP und die Abteilung System Landscape Optimization

5.3.1 Die Unternehmung SAP

5.3.2 Profil der Abteilung System Landscape Optimization

5.4 Das Projekt Marubeni

5.4.1 Kurzportrait

5.4.2 Konfiguration der Wertkettenaktivitäten

5.4.3 Koordination

5.4.4 Kundenintegration

5.4.5 Personalmanagement

5.5 Fazit und Ausblick

1 Autoren: Annette Ohr, Dirk Holtbrügge, Katrin Schillo \& Marcus Wagner.

2 Veröffentlicht in Remote Services. Neue Formen der Internationalisierung von Dienstleistungen, hrsg. v. D. Holtbrügge, H. Holzmüller \& F. v. Wangenheim. Wiesbaden: Deutscher Universitäts-Verlag, 2007, S. 141-167. 


\subsection{Problemstellung, Zielsetzung und Aufbau des Beitrages}

Die Bedienung einer stark ansteigenden Anzahl von nationalen und internationalen Kunden stellt erfolgreiche Unternehmungen vor besondere Herausforderungen. Um auch zukünftig ein effizientes und effektives Wirtschaften zu gewährleisten und weiterhin auf dem Weltmarkt wettbewerbsfähig zu sein, gilt es vor allem für expandierende Unternehmungen, strategische Überlegungen anzustellen, in welchen Regionen Know-how aufgebaut und verschiedene Wertaktivitäten angesiedelt werden sollen (vgl. Welge \& Holtbrügge, 2006, S. 147 ff.). Vor diesem Hintergrund erhält der systematische Einsatz von Remote Services einen strategischen Charakter. Remote Services sind „Absatzleistungen, die in einem technologisch vermittelten Erstellungsprozess unabhängig von der räumlichen Distanz zwischen Anbieter und Kunde erbracht werden und bei denen das räumlich entfernte Dienstleistungsobjekt über eine Steuerungskomponente verändert wird“ (Keller et al., 2006, S. 5). Remote Services bieten somit ein großes Potenzial an Kosteneinsparungen sowohl für den Kunden als auch die Unternehmung:

- Die Unterhaltung einer großen Anzahl an Standorten in Kundennähe entfällt,

- die Mitarbeiter können mehrere Kunden gleichzeitig bedienen und

- Leerzeiten durch die Anreise zum Kunden entfallen.

Allerdings hat der Einsatz von Remote Services auch Auswirkungen auf andere Managementinstrumente. Die Dislokation der Unternehmungseinheiten sowie die Entfernung zum Kunden bedingen einen höheren Koordinationsbedarf, zu dessen Bewältigung geeignete Instrumente eingesetzt werden müssen. Die räumliche Distanz zum Kunden verändert zudem die Art seiner Integration in die Dienstleistungserstellung. Für das Personalmanagement wird angenommen, dass die Mitarbeiter beim virtuellen Einsatz größere Herausforderungen meistern müssen. Auch beim virtuellen Aufeinandertreffen unterschiedlicher Kulturkreise müssen die Mitarbeiter über ausreichende Kompetenzen verfügen, um kulturelle Barrieren zu überwinden und eine reibungslose Zusammenarbeit zu gewährleisten (vgl. Holtbrügge \& Schillo, 2006).

Eine Unternehmung, in der Remote Services bereits eine große Rolle spielen, ist die deutsche Softwareunternehmung SAP. SAP war bereits Gegenstand zahlreicher wissenschaftlicher Untersuchungen und Fallstudien im Bereich der Wirtschaftwissenschaften (vgl. Bornemannet al., 2005, S. 217 ff.; Brandt \& Hütten, 2003, S. 707 ff.; Kaufmann et al., 2005; Lapin et al., 1999). Keine dieser Arbeiten beschäftigte sich jedoch mit Remote Services, bei denen SAP Pionierarbeit leistet. Daher liegt der Fokus dieser Fallstudie auf der Dokumentation und Analyse des Einsatzes von Remote Services im Hinblick auf die vier Managementinstrumente Konfiguration, Koordination, Kundenintegration und Personalmanagement.

Der Beitrag ist wie folgt aufgebaut. Nach einer Analyse des IT-Marktes folgt eine kurze Vorstellung der Unternehmung SAP sowie der Abteilung SLO (System Landscape Optimization), welche Teile ihrer Leistungen remote erbringt. Als anschauliches Beispiel für diese Form der 
Leistungserbringung wird ein Projekt von SAP bei der japanischen Warenhauskette Marubeni herangezogen. Den Hauptteil bildet die Analyse des Einsatzes der vier Managementinstrumente Konfiguration, Koordination, Kundenintegration und Personalmanagement bei Remote Services. Die Fallstudie basiert auf 16 qualitativen Interviews mit Mitarbeitern von SAP in Deutschland und Japan sowie bei Marubeni.

\subsection{Struktur des IT-Marktes}

In den letzten 10 Jahren ist im Bereich der Informationstechnologie (IT) der Bedarf an professioneller Beratung aufgrund der technischen Entwicklung und der zunehmenden Komplexität der Systeme deutlich angestiegen. Kennzeichnend dafür ist die Verschiebung der Wertschöpfungskette dieser Branche im B-to-B-Bereich vom Hardware- zum Software- und Dienstleistungsgeschäft. Weiterhin hat sich das Verhalten der Kunden in den letzten Jahren signifikant verändert. Aus der deutlich gewachsenen Kompetenz und dem Sachverständnis der Anwender erwachsen kundenindividuelle Ansprüche an IT-Systeme, die sich als Wandel von einem Verkäufermarkt zu einem Käufermarkt beschreiben lassen. Zu beobachten ist auch, dass Kunden offene Systeme bevorzugen, die den Einsatz voneinander unabhängiger Hardware und Software sowie IT-Dienstleistungen ermöglichen, um nicht von einem Hersteller abhängig zu sein. Die IT-Branche hat dieser Anforderung durch Einführung serviceorientierter Architekturen Rechnung getragen, die mittels offener Standards ein effizienteres und wirkungsvolleres $\mathrm{Zu}$ sammenwirken unterschiedlicher IT-Systeme gestatten (vgl. Speyerer, 2005, S. 43 ff.).

Nach Einschätzung der auf die IT-Branche spezialisierten Marktforschungsunternehmung IDC wuchs der weltweite Markt für Hardware, Paketsoftware, Anwendersoftware und zugehörige Dienstleistungen im Jahr 2005 um 5,9\%. Das Marktforschungsinstitut Gartner geht von einem Zuwachs von 4,9\% aus. Laut IDC verzeichnete das Segment Anwendungssoftware, in dem SAP hauptsächlich tätig ist, 2005 ein weltweites Wachstum von 5,6\%. Nach Angaben von Gartner sollen es sogar 8,4\% gewesen sein. Der Bereich Systeminfrastruktur erreichte in der Marktabgrenzung von IDC das stärkste Wachstum in der Softwarebranche. Dies signalisiert, dass Unternehmungen ihren Schwerpunkt zunehmend auf die Optimierung und Erneuerung ihrer Infrastruktur legen. Ein besonderer Wachstumsschub zeichnete sich in anwendungsbezogenen Marktsegmenten ab (vgl. SAP, 2006a, S. 63 f.).

Das Wachstum des wichtigsten Einzelmarktes für SAP, die USA, schätzt IDC im Jahr 2005 auf 4,9\%. Trotz der eher verhaltenen Konjunkturperspektiven fallen die Werte für Westeuropa mit rund 5\% ähnlich aus wie in den USA. Der asiatisch-pazifische Raum wächst mit einem Zuwachs von mindestens 6\% noch stärker. Auf die Märkte Nordamerika, Westeuropa und AsienPazifik entfallen über $90 \%$ des gesamten weltweiten IT-Geschäftes. Nach Einschätzungen des Bundesverbandes Informationswirtschaft, Telekommunikation und neue Medien (BITKOM) wuchs der deutsche Markt für IT im Jahr 2005 um 3,2\% und damit ähnlich stark wie im Vorjahr 
(vgl. SAP, 2006a, S. 63 f.).

Für 2006 wird ein ähnliches Wachstum prognostiziert. Im Bereich Anwendungssoftware wird laut Gartner sogar ein Umsatzplus von 8\% erwartet. Zu dieser Sonderentwicklung könnten nach Red Herring auch Produkte wie das von SAP und Microsoft gemeinsam entwickelte Mendocino beitragen, das die Kluft zwischen den Geschäftsanwendungen von SAP und den Büroanwendungen von Microsoft überbrückt. Die Ausgaben von mittelständischen Unternehmungen sollen nach Gartner im Jahr 2006 um etwa 7\% wachsen. Als Auslöser für diese Entwicklung sieht das Institut die schärfere Konkurrenzsituation am Weltmarkt, die eine intensivere Unterstützung der Geschäftsprozesse durch eine moderne IT-Infrastruktur verlangt. Für viele Unternehmungen erfordert dies die Modernisierung ihrer Systeme und Anwendungssoftware (vgl. SAP, 2006a, S. 89 f.).

\subsection{SAP und die Abteilung System Landscape Optimization}

\subsubsection{Die Unternehmung SAP}

SAP wurde im Jahre 1972 von den fünf ehemaligen IBM-Mitarbeitern Hasso Plattner, Dietmar Hopp, Klaus Tschira, Hans-Werner Hector und Claus Wellenreuther gegründet. Der Name SAP steht für Systeme, Anwendungen und Produkte. Die Vision der Gründer bestand darin, die erste Software zu entwickeln, die eine Datenverarbeitung in Echtzeit ermöglicht und darüber hinaus die Integration der verschiedenen Programme der Kunden zu einer einzigen Lösung erlaubt. Diese Vision hat sich erfüllt. Heute erwirtschaftet SAP mit knapp 36.000 Mitarbeitern in über 50 Ländern in den Regionen Europa, Naher Osten, Afrika (EMEA), Amerika und Asien-Pazifik einen Umsatz von 8.513 Mio. $€$ (vgl. SAP, 2006a, S. 68 f.). SAP ist der weltweit führende Anbieter von Unternehmenssoftware (vgl. Abb. 5-1) und die drittgrößte Softwareunternehmung der Welt hinter Microsoft und Oracle.

Das Produktportfolio reicht von Enterprise Resource Planning (ERP) über Customer Relationship Management (CRM), Supply Chain Management (SCM) bis zum Product Lifecycle Management (PLM). Dabei hat SAP ein breites Spektrum an Branchenlösungen entwickelt, um die besonderen Anforderungen von Kunden in verschiedenen Wirtschaftssektoren abzudecken. Das Produktportfolio umfasst nicht nur Standardsoftware, sondern auch branchen- und unternehmungsspezifische Anwendungen. Daneben bietet die Serviceorganisation der SAP, SAP Services, ein reichhaltiges Angebot an Dienstleistungen einschließlich Support, Beratung, Schulung, kundenspezifische Entwicklung und Managed Services an (vgl. Oswald, 2006, S. 21). Diese Services müssen nicht zwingend vor Ort erbracht werden, sondern können auch remote geliefert werden. 


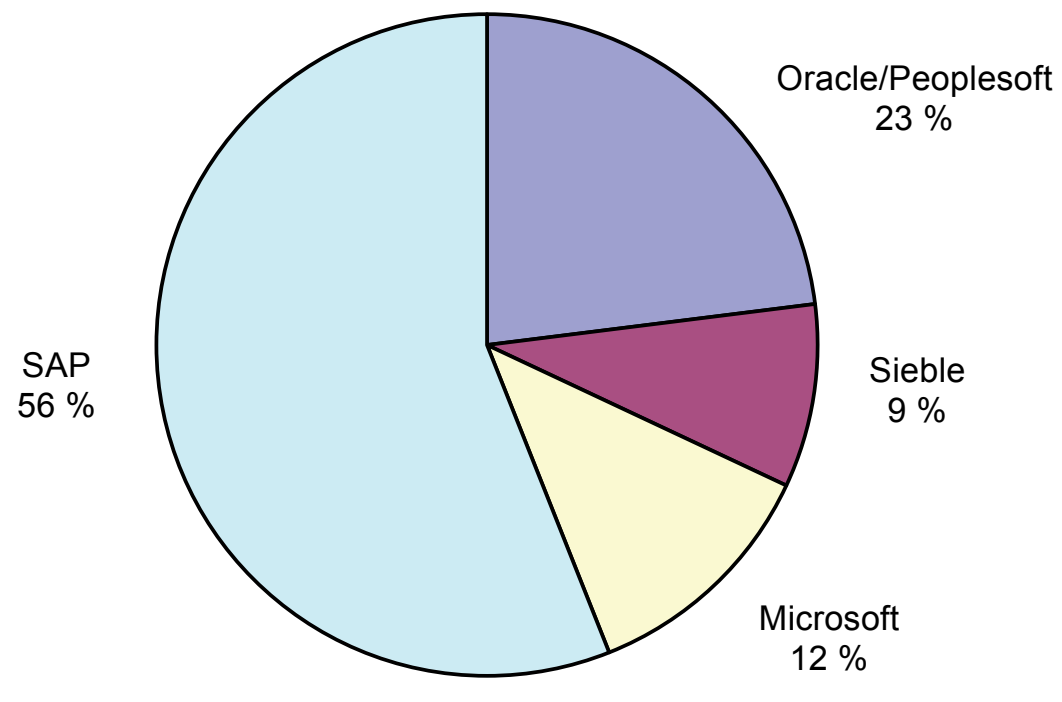

Abbildung 5-1: Marktanteile im Bereich Unternehmenssoftware im Jahr 2004

Quelle: $\quad$ Eigene Darstellung in Anlehnung an SAP 2005, S. 3.

Gegenwärtig wird die SAP-Software in knapp 32.000 Unternehmungen in 120 Ländern eingesetzt. Bis 2010 soll die Anzahl der Kunden auf 100.000 anwachsen. Bisher ist SAP überwiegend bei Großkunden aktiv. In der Zukunft wird jedoch vor allem im Mittelstand ein hohes Wachstumspotenzial gesehen. Hierzu wurde die neue Plattform NetWeaver entwickelt. Diese Technologieplattform ist mit den neuesten offenen Standards kompatibel und ermöglicht dadurch die Verknüpfung von SAP-Anwendungen mit Produkten anderer Anbieter (vgl. SAP, 2006a, S. 11).

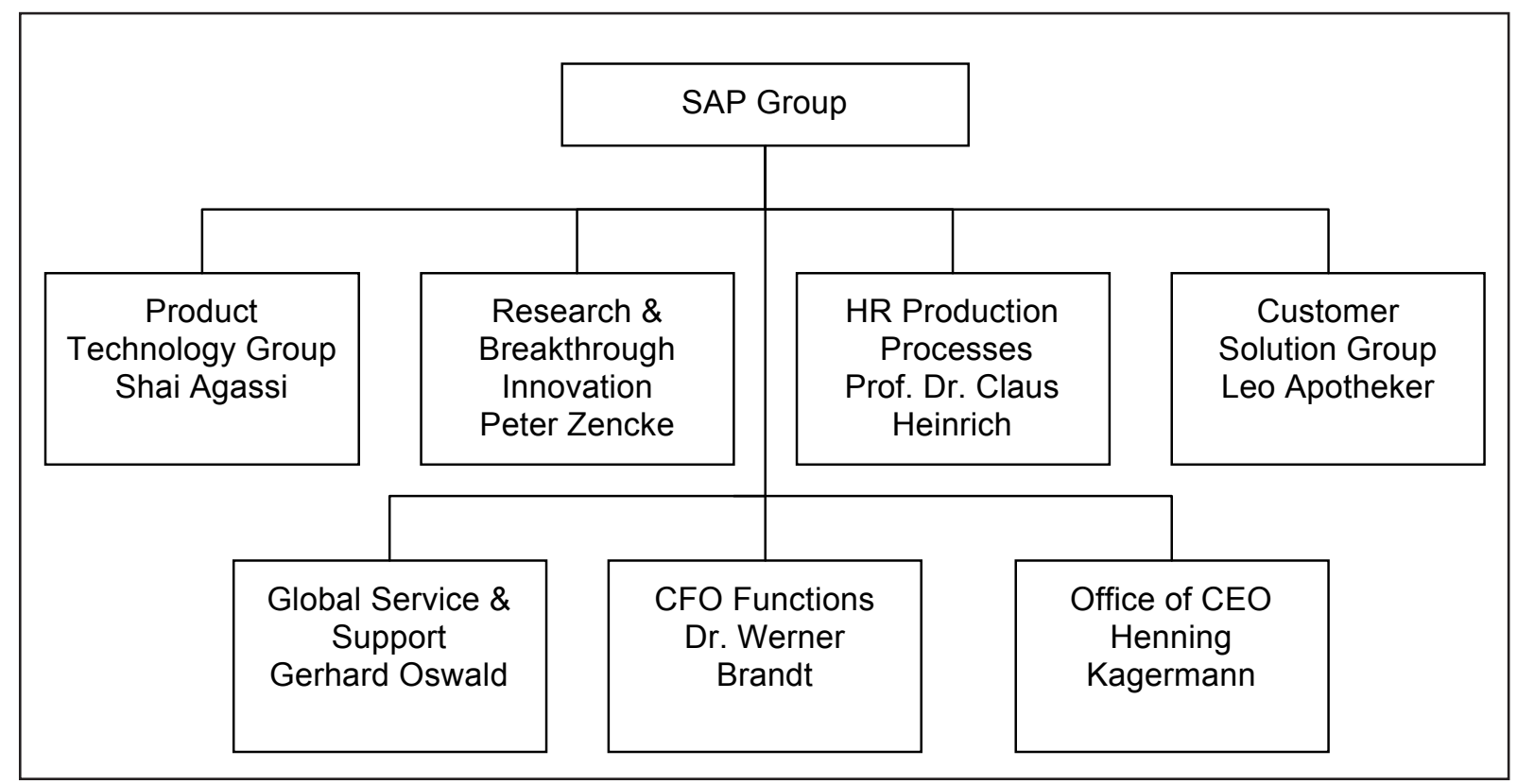

Abbildung 5-2: Organigramm der SAP AG im Jahre 2006 
Organisatorisch ist die SAP AG in sechs Vorstandsbereiche gegliedert (vgl. Abb. 5-2). Weltweit gibt es Landesgesellschaften, die den Vorstandsbereichen zugeordnet sind. Da die Landesgesellschaften nicht jegliche Art von Know-how vorhalten können, wurden zudem verschiedene Hubs gebildet. In diesen Hubs wird spezifisches Know-how vorgehalten, das die Landesgesellschaften anfordern können und damit nicht selbst aufbauen müssen. Auf diese Weise kann Know-how weltweit verteilt werden.

\subsubsection{Profil der Abteilung System Landscape Optimization}

Die offizielle Gründung der Abteilung System Landscape Optimization (SLO) erfolgte im Oktober 2001 (vgl. Anschütz, 2003). Allerdings gab es bereits Vorläuferorganisationen, die ähnliche Aufgaben wahrnahmen wie die jetzige SLO. Der Ursprung kann im 1993 gegründeten Beraterservice gesehen werden, der den Roll Out des damals neuen R/3 Systems unterstützen sollte. 1996 wurde diese Abteilung in die drei Abteilungen, Remote Services, Euro Service Entwicklung und Conversion Service aufgespaltet, wobei die beiden letzteren 2002 wieder zur SLO zusammengeführt wurden. Die heutige SLO umfasst drei Bereiche. Zum einen die Beratung, die in der Landesgesellschaft Deutschland angesiedelt und branchenorientiert ausgerichtet ist, die Standard Service Delivery sowie die Entwicklungsabteilung, die zum 1.1.2005 im Rahmen eines Taskout in die AG überführt wurde. Den SLO Hub bildet die Unternehmungszentrale in Walldorf, von wo aus alle Länder bedient werden, die keinen eigenen SLO Service haben. Von hier aus wird somit die Mehrzahl der Projekte im internationalen Umfeld durchgeführt.

Die Services von SLO sind in vier Bereiche untergliedert: Organizational Structure Changes unterstützt Änderungen, welche die Definition und Verwendung von Organisationseinheiten innerhalb der SAP-Software betreffen. System Landscape Consolidation \& Harmonization befasst sich mit Änderungen der Systemlandschaft zur Umsetzung neuer Geschäftsfeldstrategien oder zur Vereinfachung komplexer IT-Umgebungen. Die Data Harmonization erlaubt die schnelle Modifizierung größerer Datenmengen unter Gewährleistung der Konsistenz der Daten. Durch den Einsatz von Currency Conversion können Währungen konvertiert werden (vgl. Oswald, 2006, S. 73).

Prinzipiell können diese Services alle remote erbracht werden. Da die Kundenanforderungen jedoch häufig sehr individuell sind, ist der Standardisierungsgrad der Projekte, die von SLO ausgeliefert werden, weniger hoch als beispielsweise derjenigen Projekte, die die Service Delivery Group erbringt. Daher enthalten die Projekte der SLO vielfach eine gewisse Präsenz beim Kunden. Abbildung 5-3 zeigt die Wertkette für die Abteilung SLO, anhand derer aufgezeigt wird, welche Aktivitäten sich für die Leistungserbringung remote eignen.

Services werden für Anforderungen entwickelt, die wiederholt in gleicher Form bei verschiedenen Unternehmungen auftreten und mit einem standardisierten Vorgehen gelöst werden können. Die Serviceentwicklung ist daher immer marktgetrieben. Obgleich die Kunden den Input für neue Services liefern, findet die Entwicklung in räumlicher Distanz zum Kunden statt. 


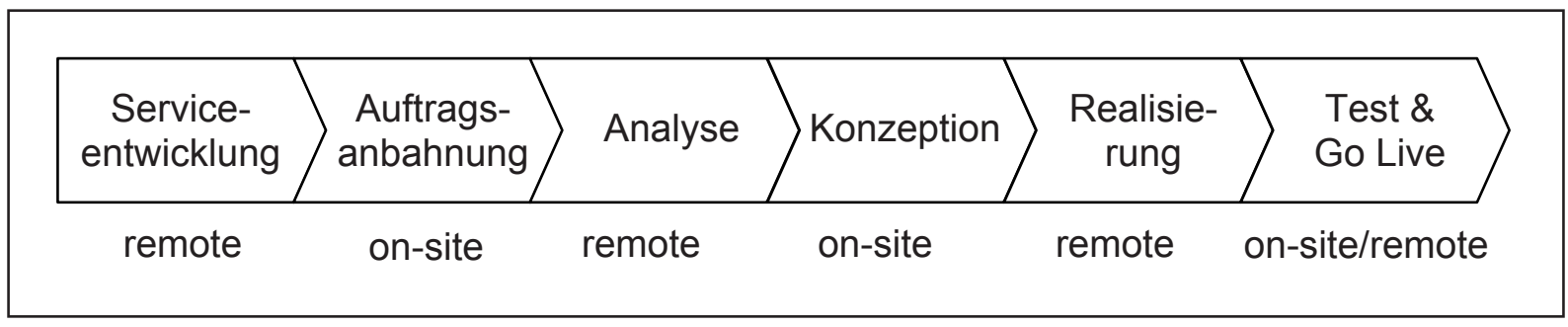

Abbildung 5-3: Wertkette der Abteilung SLO

Da SLO Projekte nur über die Landesgesellschaften abwickeln kann, findet die Auftragsanbahnung über die dortigen Vertriebsmitarbeiter statt. Diese Customer-Engagement-Manager (CEM) sind die Themenansprechpartner für SLO in den einzelnen Ländern und haben direkten Kundenkontakt. Daher läuft diese Phase on-site ab. Dies bietet gleichzeitig den Vorteil, örtliche Gegebenheiten berücksichtigen zu können, was vor allem bei den rechtlichen Aspekten der Vertragserstellung Bedeutung erlangt.

Bevor dem Kunden ein Angebot oder eine Preisschätzung unterbreitet werden kann, wird eine werkzeuggestützte Analyse des Systems durchgeführt. Diese dient zur Identifikation und Quantifizierung von Optimierungsmöglichkeiten sowie der Lokalisierung von Problemfeldern. Diese Programme und Tools liefern schnell Informationen über das System. Die Interpretation dieser Informationen wird von Experten vorgenommen. Da aufgrund der hohen Spezialisierung der Einsatz des einzelnen Mitarbeiters meist sehr kurz ist, wird diese Phase remote durchgeführt. Zudem bietet die remote Durchführung den Vorteil, dass die Experten persönlich miteinander interagieren und sich austauschen können.

Hat sich der Kunde nach Vorstellung der Ergebnisse dafür entschieden, das Projekt mit SAP durchzuführen, findet die Konzeption statt. Je nach Individualität der Anforderungen werden entsprechende Informationen des Kunden benötigt. Für eine effizientere Zusammenarbeit und reibungslose Abstimmung erfolgt dieser Teil des Projektes vor Ort.

Sobald die Konzeption erarbeitet ist, können die technischen Änderungen per Fernleitung im System des Kunden vorgenommen werden. Dies geschieht zunächst innerhalb einer Testlandschaft, die ein Abbild des Produktivsystems des Kunden ist. Sind alle Änderungen vorgenommen und die Tests fehlerfrei, werden die Änderungen im Produktivsystem vorgenommen. Das so genannte „Go Live“ findet teilweise remote und teilweise beim Kunden statt. Typischerweise nimmt der Personaleinsatz über die Wertkette hinweg zu.

Im Folgenden wird die Erbringung von Remote Services am Beispiel eines Projektes mit dem japanischen Kunden Marubeni erläutert. Dieses Beispiel eignet sich deshalb besonders gut zur Illustration, da es eines der umfangreichsten Projekte ist, die SAP SLO in den letzen Jahren durchgeführt hat. Entsprechend vielfältig waren die dabei zu lösenden Probleme. Zudem wird das Projekt auch von SAP als „Customer Success Story“ bezeichnet (vgl. SAP, 2005). 


\subsection{Das Projekt Marubeni}

\subsubsection{Kurzportrait}

Die Marubeni Corporation ist eine global agierende japanische Handelsunternehmung mit Stammsitz in Tokio. Die 1858 gegründete Unternehmung beschäftigt rund 3.700 Mitarbeiter (gesamte Gruppe 24.000). Mit 138 Niederlassungen in 74 Ländern erwirtschaftete Marubeni 2005 einen Umsatz von 56,7 Mrd. € (vgl. Marubeni, 2006).

Die Aufgabe von SAP bestand darin, zehn relativ alte SAP-Systeme durch ein neues SAPSystem abzulösen und eine gleichzeitige Migration von SAP R/3, Release 3.1H auf SAP R/3 Enterprise durchzuführen. Zusätzlich galt es, einen Buchungskreis, der auf neun Systeme bzw. Server verteilt war, auf ein System bzw. einen Server zu überführen. Schließlich sollte die Einkaufsorganisation, die auf vier Systeme verteilt war, zusammengeführt werden (vgl. Oswald, 2006, S. 76). Erschwerend kam hinzu, dass nicht nur die Systeme, sondern auch die Hardware und die Datenbank veraltet waren.

Da bei der ursprünglichen Implementierung der Software im Jahre 1990 jede Unternehmungseinheit ein eigenes System erhielt, bildete Marubeni mit diesen zehn Systemen immer die gesamte Unternehmung ab, was einen sehr großen zusätzlichen Verwaltungsaufwand bedingte. Um z.B. Berichte zu vergleichen, mussten diese jeweils aus den einzelnen Systemen ausgelesen werden, was sehr viel Zeit beanspruchte und dadurch das Managementreporting behinderte. Aufgrund des fortgeschrittenen Alters des Release war die Wartung mit zusätzlichen Kosten verbunden. Hinzu kam, dass SAP die Einstellung der Wartung angekündigt hatte. Da Marubeni seit 1997 an einem für die ganze Gruppe einheitlichen Managementsystem aufbauend auf SAP R/3 arbeitete, welches 2003 in allen Niederlassungen implementiert war, musste die zukünftige Wartung gesichert werden. Dies bedeutete zwingend das Upgrade des alten Release auf 4.7 Enterprise, was damit letztlich der Auslöser für die Serverkonsolidierung war, da sich das Upgrade eines einzigen Servers einfacher gestalten würde als dasjenige von zehn.

Der erste Kontakt zwischen Marubeni und SAP bezüglich dieses Projektes fand Anfang 2004 statt, als Mitarbeiter von Marubeni bei einem Besuch in Walldorf die Problemstellung darlegten. Im Frühjahr wurde Marubeni im Zuge einer Präsentation vor Ort die Vorgehensweise erläutert. Daraufhin gab der Kunde seine Zustimmung zum Projektvorschlag. Den folgenden Schritt bildete die Analyse der zehn Systeme, um herauszufinden, wie komplex und zeitaufwändig sich die Zusammenführung gestalten würde. Im Rahmen der zwischen 30 und 50 Tagen andauernden Analyse, die remote durchgeführt wurde, verglichen die Experten die Systeme miteinander, identifizierten Unterschiede zwischen den Systemen und lokalisierten Schwierigkeiten, die bei der Konsolidierung auftreten würden. Im Anschluss wurden die Ergebnisse wieder vor Ort beim Kunden präsentiert. Hierauf entschied sich Marubeni, das Projekt mit SAP durchzuführen. Im Mai 2005 wurde das konsolidierte System unter Einhaltung aller Vorgaben 
produktiv gesetzt. Auch historische Daten konnten erhalten und alle Eigenentwicklungen in das neue Zielsystem überführt werden. Insgesamt hatte das Projekt eine Laufzeit von einem Jahr.

\subsubsection{Konfiguration der Wertkettenaktivitäten}

\subsubsection{Besondere Herausforderungen und Chancen}

Aufgrund der technischen Möglichkeit, verschiedene Leistungen in räumlicher Distanz zum Kunden zu erbringen, stellt sich die Frage nach dem Ort der Ansiedlung der Aktivitäten sowie, ob diese zentral gebündelt oder geographisch gestreut werden sollen. Der Vorteil, Aktivitäten in Länder mit einem niedrigeren Kostenniveau zu verlagern, sind erhebliche Kosteneinsparungen. Wird dieser Vorteil teilweise an die Kunden weitergegeben, kann auch die Wettbewerbsfähigkeit gesteigert werden. „Würde man (...) weiterhin alles von Deutschland aus machen“, so ein Befragter, „wüsste ich nicht, ob SAP noch konkurrenzfähig wäre“.

Allerdings beinhaltet diese Strategie auch Risiken und Gefahren. Je stärker die Wertaktivitäten verteilt sind, desto komplexer werden die Übernahme von Arbeiten, die Zusammenarbeit und auch die Verwaltung. Aufgaben müssen verteilt und deren Erledigung überwacht werden. Allein vor dem Hintergrund der unterschiedlichen Zeitzonen gestaltet sich dies schwierig. Hinzu kommen Verständigungsprobleme, die sowohl sprachlicher Natur sein als auch aufgrund unterschiedlicher kultureller Hintergründe entstehen können. „Ich meine, je näher man an das Heimatland kommt, desto geringer werden die Probleme“, so ein Befragter. Zudem ist die Fluktuation oft viel höher als in Deutschland. Dies bedeutet einen erheblichen Mehraufwand: „Da steckt unheimlich viel mehr dahinter (als die angepriesenen Kostenvorteile). Das muss man organisatorisch erst einmal managen. Für uns ist es nicht normal, dass wir ein Work-Package in so und so vielen Seiten beschreiben und dann hinterher schreiben, dass man diesen Code auch mal testen muss. Das ist für uns irgendwie selbstverständlich, aber etwa für die (indischen Kollegen) eben nicht. Und dann gibt es hier wieder ein Hand-over-Meeting oder Sign-Off-Meeting, wo man das Ganze dann wieder zurücknimmt und kontrolliert. Wahnsinnig, der ganze Aufwand. Wenn man hier zwei erfahrene Leute hat, dann machen die das, was dort fünf machen, mit weniger Overhead", so ein Befragter. So kann es auch passieren, dass sich Projekte verschieben, weil die indischen Kollegen nicht in der Lage waren, zu liefern, was erwartet wurde. Hierdurch wird auch die Flexibilität eingeschränkt.

Die Möglichkeit der Konfiguration ist ebenfalls vom Entwicklungsgrad der einzelnen Services abhängig. Ist ein Service eingeführt, hochgradig standardisiert und erfordert daher wenig Kundenkommunikation, kann er problemlos remote erbracht und daher in einem Niedriglohnland wie Indien, China oder Osteuropa angesiedelt werden. Können Projekte mit derartigen Services durchgeführt werden, ist es sinnvoll, die Mitarbeiter, die diese Services erstellen, an einem Ort zu bündeln, so dass ein besserer Know-how-Austausch stattfinden kann. Befindet sich ein Service allerdings erst am Anfang des Lebenszyklus, ist viel Interaktion mit den Kunden und 
Entwicklungsabteilungen notwendig. Daher wird er in der Entstehensphase am Standort Walldorf realisiert, „wo sich die geballte Kompetenz befindet.“

Bei Entscheidungen über die Konfiguration dürfen deshalb nicht nur Kostenaspekte betrachtet, sondern es muss auch bedacht werden, dass die Akzeptanz einiger Kunden gegenüber Ressourcen aus Niedriglohnländern gering ausgeprägt ist: „Die Zurückhaltung wäre da schon hoch. Es gibt da sicherlich Barrieren. Die wollen jemanden in ihrer Muttersprache und auch jemanden, der schnell bei ihnen sein kann", urteilt ein Befragter. Auch die Nähe zum Kunden muss in derartige Überlegungen mit einbezogen werden. Hierzu bemerkt ein Befragter: „Wir überlegen im ersten Ansatz, welche Aktivitäten man lokal erbringen kann. Da spielen natürlich Kostenaspekte eine Rolle, da spielt Kundennähe eine Rolle. So eine Mischung hinzubekommen ist letztendlich die Herausforderung.“

\subsubsection{Derzeitige Realisierung bei SAP}

SAP unterhält neben Deutschland weltweit weitere neun Entwicklungslabore in Brasilien, Bulgarien, China, Frankreich, Indien, Israel, Kanada, Ungarn und den USA (vgl. SAP, 2006b). Sie stellen eine dynamische Gemeinschaft innerhalb der globalen Forschungs- und Entwicklungsorganisation von SAP dar. Die Labore teilen ihre Erkenntnisse, fördern kreative Entwicklungen auf weltweiter Basis und setzen somit Standards für Exzellenz in Innovation, Effektivität und Verlässlichkeit. Zudem überbrücken sie die Kluft zwischen den lokalen Marktanforderungen und der SAP-Entwicklungsorganisation und erleichtern den Zugang zur Forschungsgemeinschaft (Scientific Community) der jeweiligen Länder.

Eine besondere Bedeutung wird zukünftig dem Standort Indien zukommen. Der Vorstandsvorsitzende Henning Kagermann kündigte an, Indien zu einer strategischen Basis für die AsienPazifik-Region aufwerten zu wollen. So soll in den kommenden fünf Jahren rund 1 Mrd. US-\$ in den Standort investiert werden. Die Zahl der Angestellten soll in diesem Zeitraum von derzeit 2.750 auf 8.000 ansteigen (vgl. o.V., 2006). Zusammen mit China gehört Indien damit zu den am schnellsten wachsenden Standorten. Gründe dafür sind die hervorragende Ausbildung und die geringen Lohnkosten. So wird in Walldorf immer weniger Standardentwicklung betrieben. Diese Aufgabe übernehmen die in Asien aufgebauten Einheiten. Die Entwicklungsabteilungen in Walldorf besitzen Peer-Abteilungen z.B. in Bangalore, an die Entwicklungsarbeit abgegeben wird. Dabei werden klar definierte Arbeitspakete übertragen, so dass die Mitarbeiter vor Ort häufig den Gesamtzusammenhang ihrer Arbeit nicht kennen, sondern nur einen abgegrenzten Bereich. Ein Brückenkopf in Walldorf sendet die Arbeitspakete an die jeweiligen Personen und kontrolliert, dass die Arbeit unter Einhaltung von Zeit und Budget erledigt wird. Allerdings gibt es auch so genannte Themen-Ownerships, bei denen die gesamte Verantwortung für einen Themenbereich übertragen wird.

Seit Kurzem werden auch Beratungseinheiten in Indien errichtet. Da sich diese Entwicklung, Expertenwissen dezentral aufzubauen und vorzuhalten, erst in der Anfangsphase befindet, 
kann Walldorf noch immer als „Keimzelle“ des tiefen Expertenwissens angesehen werden. Dieses Wissen wird durch deutsche Beratungsteams exportiert, die durch Berater aus den jeweiligen Landesgesellschaften ergänzt werden, welche mit den lokalen Anforderungen besser vertraut sind. Häufig werden diese für die vertriebsnahen Aktivitäten wie das Projektmanagement eingesetzt. Die administrative Abwicklung erfolgt in jedem Fall durch lokale Mitarbeiter. Diese sind in die Projekte mehr oder weniger stark involviert, je nachdem wie weitreichend die Kenntnisse über die zu erbringende Leistung sind. Zumeist erfolgt aufgrund des vorhandenen Erfahrungswissens die Konzeption durch Mitarbeiter aus Walldorf, während die standardisierte Realisierung vermehrt in Indien durchgeführt wird.

Pioniere für die Leistungserbringung in Ländern, die eine günstigere Kostenstruktur aufweisen (Cost-Effective-Countries), waren der Service und Support. Das erste Servicezentrum wurde in Irland aufgebaut. Zu den großen drei Support-Zentren gehören heute neben Irland, das die USA betreut, sowie Österreich und Spanien, die für Mitteleuropa zuständig sind. Weitere kleinere Zentren sind über den gesamten Globus verteilt. So arbeitet der Support nach dem so genannten Follow-the-Sun Prinzip. Wenn die Mitarbeiter in Europa Feierabend haben, werden die noch offenen Meldungen von den Kollegen einer anderen Zeitzone übernommen, so dass der Support die Anfragen der Kunden 24 Stunden 7 Tage die Woche betreuen kann. Diese Art zu arbeiten wird bei SAP Global Delivery genannt.

Eine weitere Entwicklung zeichnet sich bei der Servicelieferung innerhalb von SAP ab. Die einst in Walldorf und Dresden ansässige Human Resource-Abteilung wurde im Juli 2006 nach Tschechien (Prag) verlagert. Dort werden inzwischen alle Mitarbeiterservices wie Reisekostenoder Lohnabrechnung erbracht. Die Auslagerung verdeutlicht die Strategie der Unternehmung, ausführende Tätigkeiten, die nur ein relativ geringes oder schnell erlernbares Know-how erfordern, in Ländern mit einem niedrigeren Lohnkostenniveau anzusiedeln.

\subsubsection{Zukünftige Bedeutung}

Für die Zukunft wird der geographischen Streuung der Wertaktivitäten trotz der damit verbundenen Probleme eine zunehmende Relevanz zugemessen. Dazu trägt vor allem die wachsende Bedeutung der asiatischen Märkte bei. Ein Befragter sieht „die absolute Notwendigkeit, dass wir in Asien Liefereinheiten haben, um den asiatischen Markt zu unterstützen. Aus Europa ist das zu den gegebenen Rahmenkosten in dieser Menge nicht leistbar.“ Obwohl im asiatischen Raum ein gewisses Marktpotenzial vorhanden ist, wird die Kapazität der in naher Zukunft aufgebauten Einheiten die Anfragen in der Region übersteigen. Die überschüssigen Kapazitäten werden dann zum Import von Remote Consulting-Leistungen aus Indien in den europäischen Raum genutzt. Zudem ist auch für den Bereich Service und Support angedacht, vermehrt Services aus Indien liefern zu lassen. Werden allmählich Aufgaben, die im Kompetenzbereich von Walldorf lagen, an asiatische Einheiten abgegeben, stellt sich die Frage, welche Rolle der Standort Walldorf zukünftig spielen wird. Bisher ist er das Kompetenzzentrum und die Keim- 
zelle des tiefen Experten-Know-hows. Aber auch die Mitarbeiter in den neu aufgebauten bzw. erweiterten Standorten werden Erfahrungswissen sammeln und den Know-how-Vorsprung stetig verkleinern. Der Vorstandsvorsitzende Henning Kagermann äußert sich hierzu folgendermaßen: „Wenn wir nachlassen und hinter die Qualität und Produktivität der anderen Standorte zurückfallen würden, dann würden wir in Deutschland wohl nicht weiter einstellen können. Denn die Standorte stehen untereinander in einem Wettbewerb“ (zit. nach Kroker et al., 2006, S. 64). Folgendes provokante Zitat unterstreicht diese Aussage: „Die Gleichung SAP gleich Walldorf gilt nicht mehr“" (ebenda).

\subsubsection{Koordination}

\subsubsection{Koordinationsbedarf}

Aus der Arbeitsteilung und Spezialisierung der einzelnen Unternehmungseinheiten resultieren Interdependenzen, die abgestimmt werden müssen. Erhöht wird dieser Koordinationsaufwand durch die Verteilung der Wertkettenaktivitäten auf mehrere Standorte in unterschiedlichen Ländern. „Der erste zusätzliche Standort schafft schon mal einen zusätzlichen Verwaltungsaufwand von ca. 30\% (..). Für jedes weitere Land kommen dann vielleicht noch mal 10\% Verwaltungsaufwand dazu (..)“, so ein Befragter. Da die SLO kundenindividuelle Projekte durchführt, erfolgt die Abstimmung nicht nur innerhalb der eigenen Organisation und der jeweiligen Landesgesellschaft vor Ort, sondern auch zwischen dem Kunden sowie eventuell dessen IT-Dienstleister. Somit gilt es häufig, vier unterschiedliche Parteien, die wiederum aus einer Mehrzahl an Akteuren bestehen, zu koordinieren. Das Ausmaß dieses Aufwandes unterstreicht folgende Aussage eines Mitarbeiters: „Zwei Drittel sind reine Kommunikationsarbeiten, Projektmanagementarbeiten und Koordinationsarbeiten.“

\subsubsection{Eingesetzte Koordinationsinstrumente}

\subsection{Technische Hilfsmittel}

Zur Überbrückung der räumlichen Distanz zwischen Kunde und SAP sowie zwischen SAP Deutschland und den jeweiligen Landesgesellschaften werden verschiedene Informations- und Kommunikationstechnologien eingesetzt. Technische Informationen werden vor allem durch EMails übermittelt. Erfordert ein Sachverhalt die simultane Kommunikation mehrerer Parteien, werden auch Telefonkonferenzen geschaltet. In seltenen Fällen werden Videokonferenzen anberaumt, da deren Effizienz wegen der bisher noch schlechten Bild- und Tonübertragung stark in Frage gestellt wird. So genannte WebexSessions erlauben den parallelen Zugriff auf Folien am Bildschirm bei gleichzeitiger Telefonkonferenz. Über den Windows Messenger können auf schnellem Weg kurze Nachrichten ausgetauscht werden. Ein elektronischer Kalender vereinfacht die Terminkoordination der einzelnen Projektteilnehmer. 
Die elektronische Form der Kommunikation kann jedoch persönliche Face-to-Face-Kontakte nicht ersetzen, so ein Befragter: „Klar, das ist besser als nichts, aber ich sage mal, nicht halb so effektiv wie ein vor Ort-Meeting.“ Daher müssen Remote Service-Projekte viel standardisierter und strukturierter ablaufen. Zu Anfang eines Projektes gibt es ein so genanntes Staffing, bei dem einzelne Rollen mit Personen besetzt werden. Je klarer die Aufgaben abgegrenzt werden, umso geringer wird später der Koordinationsaufwand. Da Koordination dennoch stets notwendig ist, wird hierfür ein Projektleiter eingesetzt, der Ziele und Termine vorgibt. Nach der Analysephase beraumt die SLO häufig ein persönliches Kick-off-Meeting beim Kunden an, bei dem alle beteiligten Parteien zusammenkommen. Hier wird die Projektplanung vorgestellt, der Leistungsumfang abgeklärt und eine Aufgabenverteilung zwischen SAP und dem Kunden vorgenommen. Es ist wichtig, ,dass einfach alles klar ist (..), dann kann man viel effizienter arbeiten (..). Eine richtige Abstimmung zu machen, lohnt sich", so ein Mitarbeiter. Das gesamte Konzept des Marubeni-Projektes umfasste ein rund 100-seitiges Dokument, das detailliert mit dem Kunden abgesprochen wurde: „Damit hat man schon eine Menge vorher abfangen können.“

Die Aufgabenverteilung beim Marubeni-Projekt sah folgendermaßen aus. Auf deutscher Seite war Kees van Turnhout der Projektleiter, der gleichzeitig auch auf der operationalen Ebene in das Projekt eingebunden war. SAP Japan übernahm die Betreuung des Kunden und organisierte die Kundenmeetings vor Ort. Hauptansprechpartner und Projektleiter waren hier Masanori Sugimura und Fumihiko Nishita. Die beiden Projektleiter Turnhout und Sugimura unterhielten wöchentliche Status-Meetings, die telefonisch stattfanden und bei denen offene Punkte besprochen sowie Fragen abgeklärt wurden. SAP Japan war aufgrund der sprachlichen Barrieren als Mittler eingesetzt. So wurden besprochene Aspekte und Fragen an den jeweiligen Partner weitergegeben. $\mathrm{Zu}$ Beginn des Projektes funktionierte dies nur bedingt, da die beiden japanischen Projektleiter fachfremd waren und es relativ lange dauerte, bis sie in der Lage waren, zu vermitteln, was vermittelt werden sollte. Daher äußerten diese auch den Wunsch nach zusätzlichen Mitarbeitern, die bereits das geforderte Technikverständnis besitzen. Zusätzlich galt es, mit SAP Japan große Sprachbarrieren zu überwinden, wodurch sich die Kommunikation schwierig gestaltete. Als Folge davon wurden Templates in Form von Fragelisten, Issuelisten und technischen oder Application-To-do-Listen in Excelform eingesetzt. Diese ermöglichten eine gut strukturierte Vorgehensweise. Für konkrete Probleme gab es bestimmte Themen-Ansprechpartner auf beiden Seiten. Bei den persönlichen Meetings vor Ort wurden unterstützende Visualisierungen zur Förderung des gegenseitigen Verständnisses eingesetzt. So wurde mit Powerpoint-Präsentationen und Tafelbildern gearbeitet.

Aufgrund der strukturierten Vorgehensweise hatten alle Parteien stets denselben Wissensstand. „Bei Remote Services besteht eben immer die Gefahr, dass man nur mit einem spricht und dass die anderen das nicht mitbekommen“, berichtet ein Befragter. Die klare Aufgabenverteilung half zudem, Kompetenzstreitigkeiten zu vermeiden, wie sie bei anderen Projekten zum Teil auftraten. Allerdings wird auf diese Weise auch die Flexibilität und Dynamik der Projekte eingeschränkt. Richtlinien strukturieren, welche Vorgehensweise zu befolgen ist und werden 
zumeist auf Basis der Erfahrungen früherer Projekte angefertigt. Auf diese Weise soll BestPractice-Wissen konserviert und zur Standardisierung von Prozessen herangezogen werden. Diese Richtlinien sind zentral auf einem Server abgelegt, so dass jeder Mitarbeiter darauf zugreifen kann. Verfügbar sind sie sowohl auf Deutsch als auch auf Englisch, damit sie z.B. auch von den indischen Kollegen verwendet werden können.

Einerseits wird bei der Erbringung von Remote Services zwar die Koordination der räumlich entfernten Parteien vor gewisse Herausforderungen gestellt, andererseits bedeutet dies zugleich, dass die liefernden Mitarbeiter in ein Backoffice eingebunden sind und daher schnell und unkompliziert miteinander kommunizieren können. Gerade in Vorbereitungsphasen, in denen kurzfristig Experten aus anderen Bereichen hinzugezogen werden müssen, die nicht in das Projekt eingebunden sind, ist es von Vorteil, remote zu arbeiten. Experten-Know-how muss kurzfristig verfügbar sein: „Das wäre jetzt vor Ort beim Kunden gar nicht möglich. (..) Das ist gar nicht machbar, diese geistige Arbeit vor Ort zu realisieren.“ Unabhängig von den damit verbundenen Kosten wäre es zudem sehr schwierig, ein Team zu finden, das ein Projekt komplett vor Ort realisieren könnte. Da die meisten Mitarbeiter nicht nur in ein Projekt involviert sind, sondern mehrere Projekte betreuen, würde es logistisch sehr komplex werden, die Einsätze zu steuern.

\subsection{Unternehmungskultur}

Für die Koordination dezentraler Entscheidungen ist auch die Unternehmungskultur von großer Bedeutung. „Die Firmenkultur kann einen brutal motivieren, kann einen aber auch brutal bremsen“, so ein Befragter. Bei SAP kommt deutlich das erstere zum Ausdruck. Die Mitarbeiter loben die vielen Freiräume, die ihnen die Unternehmung einräumt: „Der Unterschied ist für mich immer noch die Freiheit, die der Einzelne hat, sich zu entwickeln, Dinge selbstverantwortlich zu tun.“ Als wichtig wird von den Mitarbeitern auch empfunden, dass die Meinung des Einzelnen gefragt ist und ihnen vertraut sowie viel zugetraut wird. Viel Wert wird darauf gelegt, dass alle Mitarbeiter ihre Meinung und ihre Sichtweise zum Ausdruck bringen können. Die Arbeitsatmosphäre wird als sehr kooperativ bezeichnet. Kollegen wie auch Vorgesetzte können jederzeit um Rat gebeten werden: „Ich kann eben (..) zu dem Kollegen hingehen und fragen und werde immer offene Türen einrennen. Da sitzt jetzt keiner auf seinem Know-how, sondern die Kollegen sind immer bereit, einen zu unterstützen.“ Dieses gemeinschaftliche Miteinander, sich auf unkomplizierte und schnelle Weise gegenseitig zu helfen, wird von der SAP-Kultur gefördert. So sind Kaffeeecken eingerichtet, die das informelle Networking unterstützen. Auch zahlreiche Freizeitaktivitäten werden angeboten, die zum gegenseitigen Kennenlernen dienen und die Mitarbeiter zusätzlich motivieren. Die so geschaffene Vertrautheit äußert sich beispielsweise darin, dass man sich in der Unternehmung grundsätzlich duzt. Die lockere Atmosphäre zeigt sich zudem im legeren Kleidungsstil. Auf diese Weise werden Unternehmenswerte von SAP wie Kundenorientierung, Qualitätsbewusstsein oder auch beharrliches Streben nach herausragenden Produkten verinnerlicht. Vielfach müssen Entscheidungen deshalb nicht herbeigeführt 
werden, sondern „man weiß einfach, wie es zu tun ist“".

\subsection{Sicherheitsaspekte}

Zum Schutz der Kunden erfolgt der Zugriff auf deren Systeme über ein abgesichertes Virtual Private Network (VPN). Um überhaupt in das SAP-Netzwerk zu gelangen, sind mehrere Sicherheitsabfragen eingerichtet. Auch innerhalb des Netzes sind alle Systeme, Applikationen oder Funktionen, die man abrufen will, passwortgeschützt. Die Leitungen zum Kunden sind verschlüsselt. Zudem kann der Kunde selbst steuern, welcher User wann auf sein System zugreifen kann und welche Berechtigungen er dort hat. Die Mitarbeiter müssen ein Closure Agreement unterschreiben, in dem sie sich zur vertraulichen Behandlung der Daten verpflichten: „Wir als Mitarbeiter müssen die Daten natürlich vertraulich behandeln.“ Trotzdem ist ein großes Vertrauen seitens der Kunden notwendig, da sensible Daten zugänglich gemacht werden.

Allerdings gibt es auch Unternehmungen bzw. Einrichtungen, die sehr hohe Sicherheitsvorkehrungen treffen, wie z.B. Schweizer Banken, die Bundeswehr oder Ministerien. Hier werden Leitungen nicht geöffnet und die Erbringung von Remote Services untersagt. „Aber die ganz normalen Unternehmen haben im Allgemeinen keine Probleme damit, ihre Remote-Leitung zu öffnen. Das sind wirklich nur Unternehmen mit sehr, sehr hohen Sicherheitslevels“, konstatiert ein Befragter.

\subsection{Qualitätssicherung}

Die Sicherung der Qualität findet bei Services, wie sie SLO erbringt, durch Tests statt. Gleich zu Anfang eines Projektes werden Testzyklen geplant. Während der technischen Implementierungsphase finden zwei bis drei Testzyklen statt, bei denen das bisherige Ergebnis abgenommen wird. Alle Arbeiten werden in einer Testumgebung durchgeführt, die einen Klon des eigentlichen Produktivsystems darstellt. Erst nach dem letzten fehlerfreien Test werden die veränderten Daten in das Produktivsystem übertragen und das veränderte System Live geschaltet. Die Tests bestehen zum einen aus technischen Prüfungen. Hier wird von der SLO untersucht, ob die Datenübertragung einwandfrei war und alle Daten ins Zielsystem überführt wurden. Zum anderen ist der Kunde dafür verantwortlich, diese Tests auf Applikationsebene durchzuführen. Er muss somit überprüfen, ob seine betriebswirtschaftlichen Prozesse nach wie vor ordnungsgemäß ablaufen. Die Bedeutung solcher Tests beurteilt ein Mitarbeiter wie folgt: „Was Besseres als so einen richtigen Test gibt es eigentlich nicht, um die Qualität zu sichern.“

Um bei den Tests nicht zahlreiche Fehler zu produzieren, werden im Vorfeld weitere Maßnahmen getroffen. So müssen die Mitarbeiter die Prozesse genau kennen und wissen, welche Schritte bei speziellen Aufgabenstellungen zu unternehmen sind. Dies wird durch Standardisierung erreicht. Dazu werden Best Practices identifiziert, die in anderen Projekten wieder verwendbar sind. Damit wird eine klare Strukturierung der Prozesse erreicht. Allerdings spielt auch die Erfahrung der Mitarbeiter eine wichtige Rolle: „Je qualifizierter und erfahrener die Kollegen 
sind, umso besser die Qualität, weil die einfach viel wissen, die Zusammenhänge wissen." Von Bedeutung ist hierbei auch die Möglichkeit der Interaktion, um Wissen auszutauschen und sich gegenseitig zu fördern: „Es sind auch mehr Qualitätssicherungsmöglichkeiten gegeben, weil die eben im einem Backoffice eingebunden sind versus eine Person ist beim Kunden alleine.“

Da bei SLO werkzeuggestützt gearbeitet wird, stellt zudem die Verlässlichkeit der eingesetzten Tools einen wichtigen Qualitätsaspekt dar. Auf Entwicklungsebene ist daher ein Qualitätsmanagement implementiert (Product Innovation Lifecycle). Funktionsbeschreibungen und Testreihen sollen sichern, dass die später eingesetzten Tools ausgiebig getestet und als verlässlich eingestuft werden. Derzeit wird zusätzlich eine Zertifizierung angestrebt.

\subsubsection{Kundenintegration}

\subsubsection{Rolle des Kunden}

Remote Services werden als Teamprojekte durchgeführt. Dem Coreteam bei SAP steht zumeist ein Projektteam des Kunden gegenüber. Dadurch findet die Einbindung des Kunden von Beginn an statt, da nur er seine gewünschte Zielsituation bestimmen kann. Er muss Ressourcen bereitstellen, die die SAP-Mitarbeiter mit dem notwendigen fachlichen Input versorgen. Am stärksten beansprucht wird der Basisansprechpartner des Kunden. Auch die Verantwortung für die Systemadministration fällt in seinen Aufgabenbereich. Er muss die notwendigen Voraussetzungen schaffen, damit die SAP-Mitarbeiter in der Systemlandschaft arbeiten können. Zudem muss er seine Nutzer vorbereiten und auf die Umstellung schulen. Seine Hauptaufgabe besteht allerdings im Test der Systeme. Sobald von Seiten der SAP ein Test beendet ist, muss der Kunde das abgelieferte Ergebnis überprüfen. Dies ist für die SAP-Mitarbeiter nicht möglich, da sie die Geschäftsprozesse des Kunden nicht im Detail kennen. Deshalb betont ein Mitarbeiter: Der Kunde ,ist extrem wichtig, weil er seine Geschäftsprozesse testen muss. SAP hat unglaublich viele Funktionen und Möglichkeiten, wie man es einstellen und benutzen kann. Das kann man unmöglich alles programmieren und vorsehen. Wir versuchen eben so weit wie möglich die Geschäftsprozesse zu verstehen und dann beim Merger zu berücksichtigen, aber letztlich muss der Kunde testen, denn das können wir nicht wissen. Deswegen geht es nicht, wenn er nicht testet. Dann scheitern solche Projekte auch.“

Die Intensität der Kundeninteraktion hängt vor allem davon ab, ob die Anforderungen eher technischer oder betriebswirtschaftlicher Art sind. Handelt es sich um rein technische Aspekte, ist relativ wenig Know-how des Kunden erforderlich. Bei betriebswirtschaftlich motivierten Aufgabenstellungen ist dagegen eine deutlich höhere Interaktion erforderlich: „Je höher die Interaktion mit dem Kunden ist, desto geringer ist der remote Anteil.“ So lässt sich auch der Wechsel zwischen remote und on-site erklären. Aufgaben, die einen hohen Abstimmungsbedarf aufgrund eines geringen Standardisierungsgrades erfordern, werden beim Kunden vor Ort aus- 
gearbeitet. Das Verhältnis von remote und on-site-Tätigkeiten hängt zudem davon ab, was der Kunde selbst im Projekt leisten kann bzw. was er zu leisten bereit ist.

\subsubsection{Beobachtbarkeit der Dienstleistungserstellung}

Ein wesentliches Element von Remote Services ist, dass der Kunde den Erbringern der Dienstleistung nicht bei der Arbeit zuschauen kann. Einige Befragte von SAP Deutschland sind der Auffassung, dass dies kein Problem sei: „Er sieht ja direkt, dass da etwas passiert, wenn er ins System schaut.“ „Wenn man ein System migriert hat, sind die Daten physikalisch anderswo platziert. Das kann der Kunde auch sehen.“ Andere Mitarbeiter bemängeln dagegen, dass der Arbeitsfortschritt für den Kunden oft nicht oder nur zum Teil sichtbar ist: „Das Hauptproblem ist eben, dass der Kunde nicht so richtig mitbekommt, was wir hier machen, also wie weit wir mit dem Projekt sind.“ Diese Mitarbeiter betonen die Wichtigkeit der Dokumentation der Arbeitsschritte, die der Kunde als Bearbeitungsfortschrittsmeldung erhalten sollte. „Da haben die wirklich gesagt, Ihr seid ja schon viel weiter als wir gedacht haben. Und daraufhin haben wir gemerkt, dass wir ein bisschen mehr kommunizieren müssen, dafür sorgen müssen, dass dieser Informationsfluss besser wird. Die müssen nämlich schon wissen, was wir hier machen“, so ein Befragter. Die Übermittlung des Prozessfortschrittes sollte nach deren Ermessen aktiv betrieben werden. Dies kann über Statusberichte oder Telefonkonferenzen geschehen.

Zurückführen lassen sich diese unterschiedlichen Auffassungen auf die unterschiedlichen Bezugspunkte im Leistungserstellungsprozess. So stellen die Mitarbeiter, die die Leistungserbringung für beobachtbar halten, auf Zeitpunkte ab, an denen bereits Ergebnisse vorliegen bzw. Veränderungen vorgenommen wurden. Diese sind dann für den Kunden entweder in schriftlicher Form oder anhand der Systemdaten sichtbar. Die anderen Mitarbeiter stellen auf Phasen $\mathrm{ab}$, in denen Vorarbeit geleistet, aber kein sichtbarer Output produziert wird.

Für die Mitarbeiter von Marubeni gestaltete sich der Leistungserstellungsprozess als Black Box, was als sehr frustrierend empfunden wurde. Hierzu äußerte sich ein Befragter folgendermaßen: „Wir wissen nicht, was die machen, bis wir dann nach einer Woche wieder erfahren, was in dieser Zeit passiert ist. Das ist sehr frustrierend.“ Den wöchentlichen Statusabgleich empfand Marubeni als nicht ausreichend. Um dem Bedürfnis nach Informationen des jeweiligen Kunden nachzukommen, sollte daher im Einvernehmen mit diesem beschlossen werden, in welchem Zyklus der Projektfortschritt gemeldet wird.

\subsubsection{Probleme bei der Kundenintegration}

Probleme bei der Kundenintegration führen die SAP-Mitarbeiter bei internationalen Kunden auf zwei Aspekte zurück, und zwar zum einen auf Sprachschwierigkeiten und zum anderen auf kulturelle Unterschiede. Bis ein gemeinsames Verständnis über die Leistungserbringung gefunden wird, ist der Aufwand im Vergleich zu einem deutschen Kunden erheblich höher. So kann es sein, dass sich die verschiedenen Partner aufgrund der unterschiedlichen Kulturen 
nicht aufeinander einstellen können. Dadurch wird die Kommunikation und Zusammenarbeit schwieriger: „Die Denkweise ist dort eine ganz andere. Und auch der Arbeitsstil unterschiedet sich sehr.“ Teilweise ist auch die Art der Kommunikation unterschiedlich. In Japan „muss alles schriftlich erfolgen. Und nach Möglichkeit in Matrix-Form, also in Excel“, berichtet ein Mitarbeiter. So sind spontane Telefonate mit den Mitarbeitern des Kunden eher selten, da sich deren Englischkenntnisse vorwiegend auf die geschriebene Sprache und weniger auf die gesprochene beziehen: „Unsere Mitarbeiter können Englisch häufig sehr gut schreiben und lesen, aber nicht sprechen.“ Mit einem Telefonat würde man sie daher in Verlegenheit bringen. Zudem wurde von den SAP-Mitarbeitern als schwierig empfunden, dass Japaner oft nicht direkt kommunizieren. Werden mehrere Vorschläge unterbreitet, nicken sie diese alle ab, und die SAP-Mitarbeiter wissen nicht, welcher Vorschlag nun wirklich angenommen wurde. Dadurch ist es für sie schwierig, die Wünsche des Kunden herauszufinden. Die Detailorientierung der japanischen Kunden führt zudem dazu, dass diese sehr viele Fragen stellen und alles äußerst genau erklärt haben wollen. Per Telefon und E-Mail gestaltet sich dies äußerst schwierig. Daher ist ein gewisser Anteil an persönlicher Kommunikation erforderlich: „Wenn man das remote machen müsste, würde man auf beiden Seiten nicht glücklich. Da ist es besser, vor Ort zu gehen und alles im Detail zu besprechen.“ Allerdings betonen die Befragten, dass diese Schwierigkeiten gleichfalls beim Kunden vor Ort auftreten und keinen remote-spezifischen Charakter haben. Hinzu kommt beim Einsatz vor Ort, dass durch Gesten, die aus dem europäischen Raum bekannt sind, jedoch in anderen Kulturen nicht zwingend dieselbe Bedeutung besitzen, Fehlinterpretationen in eine Kommunikation hineingetragen werden. Daher gilt: „Desto näher das Land kulturell ist, desto einfacher ist es auf jeden Fall.“

Indes können kulturelle Unterschiede in manchen Situationen auch vorteilhaft sein. In der japanischen Kultur steht der Kunde in der Hierarchie höher als der Dienstleister. So ist es für die Landesgesellschaft, in der vorwiegend Japaner tätig sind, schwer möglich, den Kunden bei unsinnigen Anforderungen zurechtzuweisen. SAP Deutschland kann hier seinen Ausländerstatus nutzen: „Wir sind zwar auch niederrangiger, aber wir können uns das erlauben, denn wir kennen ja die Kultur nicht [lacht].“

\subsubsection{Kundenbindung}

Die Erfahrung der SAP-Mitarbeiter zeigt, dass die Kundenbindung durch die Kundenintegration verstärkt wird: „Die (Kundenintegration) wirkt sich hoch (auf die Kundenbindung) aus, denn da lernt man sich kennen und schätzen oder auch nicht schätzen." Besonders wichtig ist, dass der Kunde einen Hauptansprechpartner bei SAP hat, der sich mit den Prozessen des Kunden sehr gut auskennt und dessen Probleme vorrangig bearbeitet: „Denn über die zwei Personen wird eine Kundenbindung aufgebaut.“ Wenn zudem die Kommunikation gut funktioniert und die Kunden mit der Leistung zufrieden sind, wenden sie sich bei neuen Anforderungen wieder an die SAP. Beim Remote Consulting sind die persönlichen Kontakte allerdings überwiegend auf Telefon und E-Mail beschränkt. Dadurch ist es deutlich schwieriger, eine persönliche Bezie- 
hung herzustellen, welche positiv auf die Kundenbindung wirkt.

Der Kunde Marubeni wurde bereits in der Vergangenheit erfolgreich von SAP beliefert. Im Rahmen des Vorgängerprojektes hatte die Unternehmung unter Beweis gestellt, ein kompetenter Partner für derartige Problemstellungen zu sein. Die Kundenbindung wird hier dadurch offensichtlich, dass trotz der Möglichkeit der Serverkonsolidierung durch andere Anbieter eine solche aufgrund der guten Geschäftsbeziehung zu SAP nicht in Betracht gezogen wurde.

\subsubsection{Erfolgsfaktoren auf Kundenseite}

Damit ein Remote Service-Projekt erfolgreich abgewickelt werden kann, müssen bestimmte Faktoren beim Kunden erfüllt sein. Wichtig ist zum einen eine klare und eindeutige Definition der Anforderungen. Zudem muss der Kunde mit der Teilung der Verantwortlichkeiten einverstanden sein, da nicht die komplette Leistung von SAP erbracht werden kann. Für jeden involvierten Bereich muss es feste Ansprechpartner geben, die bei internationalen Projekten über ausreichend Englischkenntnisse verfügen sollten. Unerlässlich für den Projekterfolg ist schließlich das Vertrauen des Kunden in die Unternehmung und in die von dieser erbrachten Dienstleistung.

\subsubsection{Vertrauensbildende Maßnahmen}

Um eine Vertrauensbasis zwischen SAP und den Kunden zu schaffen bzw. diese zu stärken und auszubauen, werden unterschiedliche Maßnahmen ergriffen. Vor dem Hintergrund der Bedeutung persönlicher Beziehungen zwischen den Mitarbeitern von SAP und denen des Kunden wird zu Anfang eines Projektes versucht, Meetings beim Kunden vor Ort abzuhalten, „damit man in der kurzen Zeit, in der man dort ist, eine Vertrauensbasis entwickelt.“ Dadurch sollen sich die Parteien kennen lernen. Wichtig sind auch Kontakte nach der regulären Arbeitszeit: „Abends sind wir dann oft Essen gegangen. Wir sind von Kunden sehr nett eingeladen worden. Auch SAP Japan hat uns eingeladen. Man hat zudem solche Social Events gemacht. Und das war schon gut, dass man einander kennenlernt.“ Die Befragten sind überzeugt, dass persönliche Beziehungen die Zusammenarbeit erleichtern. Gerade in Ländern wie Japan ist die Durchführung eines Projektes ohne vorheriges gegenseitiges Kennenlernen nicht möglich. „Es ist einfach leichter, wenn man sich kennt, wenn man die Gesichter kennt, mit denen man dann hinterher telefoniert oder mit denen man dann schreibt", berichtet ein Mitarbeiter. Bei Projekten, die ausschließlich remote abgewickelt werden, wird empfohlen, die Kommunikation bevorzugt per Telefon anstatt per E-Mail abzuwickeln, denn „durch die Stimme kann schon so eine gewisse Vertrautheit geschaffen werden." Einig sind sich die Befragten darüber, dass es keine einfache Aufgabe darstellt, per Telefon oder E-Mail Vertrauen aufzubauen. Dabei ist es allerdings von Vorteil, Teil der Organisation SAP zu sein: „Wir haben schon einen Vertrauensvorschuss, denn wir kommen eben mit den drei Buchstaben SAP an." Auch für Marubeni stellte dies einen wichtigen Aspekt dar: „Wir vertrauen in die Technik und Leistungsfähigkeit der SAP AG.“ 
Als vertrauensbildend sehen die Befragten zudem an, Probleme zu lösen sowie durch gute Leistungen zu überzeugen: „Das ist, glaube ich, auch wichtig, dass die denken, dass wir ihr Problem verstehen und eine Lösung dafür haben.“ Durch die Aussage eines Marubeni-Mitarbeiters kann dies bestätigt werden: „Als wir das erste Mal in Deutschland waren und uns eine ganze Reihe unterschiedlicher Lösungswege vorgestellt wurde, waren unsere Zweifel ausgelöscht.“ Die Kombination aus persönlicher Beziehung und Überzeugung durch kompetentes Auftreten schafft letztlich eine derart starke Vertrauensbasis, die Kunden zur Zustimmung der Leistungserbringung remote veranlasst. Wurde das Vertrauen im Zuge der Durchführung eines Projektes erworben, kommen Kunden mit Folgeprojekten wieder auf die Unternehmung zurück. Dies traf auch auf Marubeni zu.

\subsubsection{Akzeptanz von Remote Services}

Die Akzeptanz von Remote Services wird von den SAP-Mitarbeitern überwiegend als sehr hoch eingeschätzt: „Die ist hoch, sehr hoch würde ich sagen.“ Für viele Kunden stellt es kein Problem dar, dass die Mitarbeiter nicht vor Ort sind. Eine Mitarbeiterin vermutet, dass die Kunden eine on-site-Tätigkeit wahrscheinlich bevorzugen würden, aber aus Kostengründen Remote Services mehr und mehr akzeptiert sind. Zudem wird eine über die Jahre steigende Akzeptanz festgestellt. Unterschiede in der Akzeptanz werden eher zwischen verschiedenen Branchen als zwischen unterschiedlichen Ländern identifiziert. Für japanische Kunden wird jedoch hervorgehoben, dass diese sehr viel persönliche Betreuung benötigen und daher immer eine gewisse Präsenz vor Ort erforderlich ist. So konstatiert der Projektverantwortliche von Marubeni, dass sich die Unternehmung das Projekt ohne die Landesgesellschaft in Japan, die diese Betreuung hauptsächlich übernahm, nicht hätte vorstellen können.

Trotz der hohen Akzeptanz ist es schwer vorstellbar, dass Remote Services vor-Ort-Leistungen völlig ersetzen: „Ich denke, von den Kommunikationsmöglichkeiten her wird das weiter wachsen. Wird aber nie den Bedarf von vor-Ort-Leistungen ersetzen. Der wird nie gegen Null gehen.“ Dies gilt besonders für wenig standardisierte Leistungen, „,weil die persönliche Ebene (hier) eine große Rolle spielt.“ Die hoch standardisierten Leistungen der Global Delivery Einheit werden allerdings zum Großteil ausschließlich remote erbracht.

\subsubsection{Personalmanagement}

\subsubsection{Besondere Herausforderungen und Chancen}

Der Einsatz von Remote Services bedingt, dass einige Mitarbeiter nur noch virtuell ins Ausland entsandt werden (vgl. Holtbrügge \& Schillo, 2007). Daraus ergeben sich veränderte Anforderungen. Durch den Wegfall persönlicher Kommunikationsmöglichkeiten besteht die Gefahr, dass ein gegenseitiges Verständnis zwischen geographisch entfernten Mitarbeitern nicht entstehen kann und sich interkulturelle Missverständnisse verstärken. Zudem hat das neue Zielkun- 
densegment Mittelstand aufgrund seiner geringeren Unternehmungsgröße häufig auch weniger internationale Erfahrungen und damit eine geringer ausgeprägte interkulturelle Kompetenz. Die Kluft zwischen den Kulturen zu überwinden und damit die Basis für eine erfolgreiche $\mathrm{Zu}-$ sammenarbeit zu schaffen, ist Aufgabe der Mitarbeiter von SAP. Dazu ist eine ausgeprägte interkulturelle Kompetenz erforderlich, die, sofern nicht bereits durch internationale Erfahrungen vorhanden, entwickelt werden muss. Geeignete Methoden des Personalmanagement generieren so aus der Ressource Mitarbeiter einen strategischen Wettbewerbsvorteil.

\subsubsection{Derzeitige Realisierung bei SAP}

\subsection{Personalbedarfplanung und-deckung}

Bei größeren Projekten gilt es, entsprechende Mitarbeiter gemäß den jeweiligen Anforderungen zu identifizieren und diese den Projekten zuzuordnen. Dazu wird im Vorfeld geprüft, welche Funktionalitäten die jeweilige Kundenunternehmung einsetzt. Hierzu gibt es bei SAP ein Ressourcenmanagement, das alle freien Ressourcen verwaltet und die geeigneten Mitarbeiter für anstehende Aufgaben auswählt. Die identifizierten Mitarbeiter werden häufig nur kurzfristig benötigt: „Der Zugriff muss auch recht kurzfristig erfolgen können.“ Die Projektmitarbeiter kommen nicht notwendigerweise aus der Abteilung SLO, sondern häufig auch aus anderen Abteilungen. Bei der Teamzusammenstellung muss darauf geachtet werden, ein Gleichgewicht zwischen Experten und Mitarbeitern mit wenig Erfahrung zu finden, so dass in allen Teams eine bestimmte Zahl von Experten zu finden ist.

\subsection{Personalentwicklung}

Im Zuge der Personalentwicklung sollen die Mitarbeiter auf die speziellen Anforderungen ihres Tätigkeitsfeldes vorbereitet werden. Für die Arbeit mit Remote Services ergeben sich zusätzliche Anforderungen. Ein besonderer Anspruch von Remote Services besteht darin, die Wünsche des Kunden zu erfassen und trotz fehlenden Gegenübers dessen Stimmungslage zu erkennen und entsprechend darauf zu reagieren.

Auch Verständigungsprobleme durch sinnentleerte E-Mails müssen überwunden werden. Weiterhin muss darauf geachtet werden, dem Kunden den Projektstatus zu übermitteln. Der Kontakt, der bei Tätigkeiten direkt beim Kunden automatisch gegeben wäre, muss bei Remote Services bewusst gestaltet werden. Da Remote Service-Projekte strukturierter ablaufen, müssen die Mitarbeiter vorausschauend planen können und von Beginn an die Verantwortlichkeiten definieren. Da Ressourcen flexibler einsetzbar sind und Leerzeiten wegfallen, müssen sich die Mitarbeiter schneller in neue und stets veränderte Sachverhalte einarbeiten und zudem damit zurechtkommen, dass sie während eines Arbeitstages mehr leisten müssen, da Pausen durch Anfahrten zu Kunden nicht mehr entstehen.

Abgesehen von diesen Besonderheiten wird betont, dass sich die Anforderungen an die tech- 
nischen Qualifikationen nicht unterscheiden: „Speziell ausgebildete Remote Mitarbeiter gibt es bei uns nicht.“ Entgegen der Erwartung wird bezüglich der Soft Skills hervorgehoben, dass diese bei vor Ort erbrachten Leistungen sogar höher ausgeprägt sein sollten: „Ich würde eher sagen, dass man on-site mehr Skills, mehr Soft Skills braucht als remote.“ Diese Aussage lässt sich darauf zurückführen, dass die Befragten sich hier auf Mitarbeiter beziehen, die ausschließlich hoch standarisierte Remote Services erbringen, die vorwiegend technisches Verständnis und wenig Abstimmung mit dem Kunden erfordern. Für diese Mitarbeiter spielt die persönliche Beziehung zum Kunden eine untergeordnete Rolle, da die Kommunikation hauptsächlich technische Aspekte umfasst. So kommen hier kulturelle Unterschiede weniger zum Tragen. Darüber hinaus wurde die Problemstellung bereits durch andere Mitarbeiter, beispielsweise durch die lokalen Mitarbeiter der jeweiligen Landesgesellschaft erfasst, die in diesem Rahmen die Aufgabe des Vertrauensaufbaus übernahmen.

Unterdessen müssen die Mitarbeiter von SLO, deren Tätigkeitsspektrum weniger strukturierte Aufgabenstellungen und kundenindividuelle Anforderungen umfasst, sowohl über ausgeprägte technische Qualifikationen als auch über Soft Skills verfügen, die im Umgang mit internationalen Kunden gerade bei fehlendem Face-to-Face-Kontakt in besonderem Maße beansprucht werden.

Vorbereitet auf ihre Tätigkeit werden die Mitarbeiter des Bereichs SLO, der sehr technisch orientiert ist, vor allem durch Trainings-on-the-job. Neue Mitarbeiter werden sofort in laufende Projekte integriert. Dabei erhalten sie einen erfahrenen Mitarbeiter der Abteilung als Mentor, der ihnen zur Seite steht: „Dann habe ich noch den Entwickler, der diese Organisationslösung machte, betreut, im Sinne von Coaching.“ Da es sich um stark spezialisierte Arbeit handelt, dauert es ca. 1 1 $1 / 2$ Jahre, bis die Mitarbeiter alle Tools kennen. Den Mitarbeitern wird auch ein entsprechendes Kursangebot offeriert, das hauptsächlich technische Trainings umfasst: „Gut, ich hatte einmal so ein bisschen ein Soft Skill Training, aber hauptsächlich waren das, als ich angefangen habe, technische Trainings.“ Da neue Mitarbeiter in das Backoffice eingebunden sind, findet ein beschleunigter Wissenstransfer statt, wodurch Ausbildungskonzepte vereinfacht werden und eine bezogen auf den Wissenstand heterogene Gruppe an Mitarbeitern schneller auf ein einheitliches Niveau gebracht werden kann.

Im Bereich Entwicklung erhalten die Mitarbeiter auch interkulturelle Trainings, die sie auf die Zusammenarbeit mit den ausländischen Kollegen vorbereiten sollen. Diese sind als Workshops ausgestaltet, in denen Rollenspiele stattfinden, Verhaltensregeln gelernt werden und deren Bedeutung verdeutlicht wird. Im Bereich Beratung werden diese jedoch nicht angeboten. So erhielt auch das Marubeni Coreteam keine japanspezifische Vorbereitung. Einige Mitglieder hatten aus vorherigen Projekten allerdings bereits Asienerfahrung gesammelt bzw. sich privat mit der Landeskultur auseinandergesetzt. Häufig wird argumentiert, dass die Herausforderungen mit gesundem Menschenverstand und einer gewissen Sensibilität auch ohne spezielle Trainings gemeistert werden können. Trotzdem halten die Befragten interkulturelle Trainings für sinnvoll 
und würden auch daran teilnehmen, sofern ein entsprechendes Angebot gemacht würde.

Insgesamt wird deutlich, dass technische Aspekte stark im Vordergrund stehen, während Soft Skills weitestgehend vernachlässigt werden. Da diese allerdings besonders im Umgang mit Kunden, mit denen kein regelmäßiger persönlicher Kontakt besteht, von großer Bedeutung sind, sollte hier zukünftig über geeignete Fördermaßnahmen nachgedacht werden. Besonders für interkulturell unerfahrene Mitarbeiter ist dies wichtig (vgl. Holtbrügge \& Schillo, 2008).

\subsection{Personaleinsatz}

Die Arbeitsinhalte der SLO sind sehr anspruchsvoll und erfordern von den Mitarbeitern ein ausgeprägtes Know-how. Die unterschiedlichen Aufgabenstellungen bieten ein sehr abwechslungsreiches Tätigkeitsspektrum. Vielfach können sich die Mitarbeiter auch selbst neue Aufgabenstellungen suchen. Da die Erbringung der Leistung Expertenwissen erfordert, wird diese zumeist durch ein Team erledigt, das selbständig über die interne Aufgabenverteilung entscheiden kann. Alle Teammitglieder bearbeiten gleichrangig ihren jeweiligen Aufgabenbereich. Auch der Projektleiter ist meist in operativer Weise in das Projekt eingegliedert und übernimmt nicht ausschließlich Projektmanagementaufgaben.

Aufgrund der Möglichkeit der remoten Leistungserbringung können die Mitarbeiter den Großteil der Arbeitszeit in ihrer gewohnten Arbeitsumgebung mit den gewohnten Arbeitsmitteln verbringen. Um bei Projekten schnell und flexibel auf das Know-how andrer Ressourcen zurückgreifen zu können, die nicht zum Kernteam eines Projektes gehören, teilen sich meist vier bis sechs Mitarbeiter ein Büro.

Da die Mitarbeiter von SLO für alle Länder, abgesehen den USA und Kanada, die über eine eigene SLO-Abteilung verfügen, zuständig sind, findet die Zusammenarbeit häufig mit Kollegen und Kunden anderer Zeitzonen statt. Um ein größeres Zeitfenster zu schaffen, in welchem alle Partner gleichzeitig aktiv werden können, müssen sich die SAP-Mitarbeiter bezüglich ihrer Arbeitszeit an den Remote-Standort anpassen, was entweder bedeuten kann, morgens früher in das Büro zu kommen oder abends länger zu bleiben. Daher spielt die Möglichkeit der freien Zeiteinteilung des Einzelnen bei der Aufgabenerledigung eine wichtige Rolle. So können die Mitarbeiter den Beginn und das Ende des Arbeitstages sowie Pausen je nach Projekterfordernis selbst bestimmen. Das große Vertrauen in die Mitarbeiter spiegelt sich in der fehlenden Zeiterfassung wider, was zusätzlich zu deren Motivation beiträgt.

\subsection{Personalführung}

Die Personalführung bei SLO liegt im Aufgabenbereich des Abteilungsleiters. Dieser lässt seine Mitarbeiter sehr eigenständig arbeiten und bringt ihnen in hohem Maß Vertrauen entgegen: „Man kann sehr selbständig arbeiten. Wir haben recht viel Freiraum.“ So können die Mitarbeiter ihre Wochenplanung an abzuarbeitenden Projekten und Aufgaben selbständig aufstellen und bestimmen sogar bei Projekten häufig selbst ihren Projektleiter, der die Koordination über- 
nimmt. Auch werden sie selten Projekten zugeteilt, sondern können vielfach selbst bestimmen, an welchen Projekten sie mitarbeiten möchten. Aufgrund des hohen Qualifikationsniveaus der Mitarbeiter eignet sich dieser äußerst partizipative Führungsstil sehr gut und trägt zur Motivationssteigerung der Mitarbeiter bei. So kann der Abteilungsleiter entspannt äußern: „Die sind alle erwachsen.“ Allerdings wäre die Realisierung der Führungsaufgabe auf andere Art und Weise wegen der großen Zahl der Mitarbeiter in der Abteilung kaum denkbar. Zudem erfordert die Vielzahl der anstehenden Projekte, die sich häufig nur über einen kurzen Zeitraum erstrekken und wenige Ressourcen beanspruchen, eine gewisse Eigendynamik der Mitarbeiter in der Koordination.

\subsection{Arbeitszufriedenheit}

Die Mitarbeiter der SLO sind daran gewöhnt, sowohl remote als auch on-site zu arbeiten. Die Mischung empfindet die Mehrheit als sehr angenehm: „Also ich mag diese Mischung.“ Obwohl die Arbeit mit dem Kunden im multikulturellen und -nationalen Umfeld als Job Enrichment angesehen wird, motivieren Remote Services in anderer Hinsicht. So können durch den verminderten Reiseaufwand soziale Kontakte besser gepflegt werden. Zudem bieten Remote Services Müttern mit Kindern oder familiengebundenen Mitarbeitern die Chance, weiterhin im Beruf tätig zu sein. Speziell auf die Arbeit bezogen wird hervorgehoben, dass sich diese remote effektiver gestalten lässt, „denn ich hab hier einfach mehr Ruhe. Wenn ich irgendwelche Dinge im Detail durchdenken muss, habe ich meine gewohnte Arbeitsumgebung, meine gewohnten Arbeitsmittel. Da komme ich eigentlich zu besseren Ergebnissen, als wenn ich beim Kunden sitze.“ Aufgrund der Tatsache, sich seine Zeit besser einteilen zu können, werden von einem Mitarbeiter Remote Services deshalb zumeist bevorzugt.

\subsection{Fazit und Ausblick}

Remote Services sind bei SAP bereits seit vielen Jahren im Einsatz. Die ersten Anwendungsfelder bildeten Archivierung und Upgrades, d.h. wiederkehrende Aufgaben, die beim Wechsel auf ein neues Release zu leisten sind. Da die Betreuung des Kunden vor Ort hohe Kosten verursacht, entstand die Idee, derartige Leistungen remote zu erbringen. Große Bedeutung erlangten Remote Services allerdings erst im Zuge der Euroumstellung, als auf jedem R/3 System eine Conversion durchgeführt werden musste. Es eignen sich jedoch nicht alle Projekte oder Anforderungen zur remoten Abwicklung. Dazu müssen Prozesse sehr klar definiert und strukturiert sein und Probleme mit einem standardisierten Vorgehen gelöst werden können. Zudem ist eine viel exaktere Planung notwendig. Mit der Komplexität von Projekten geht allerdings der Standardisierungsgrad zurück. Daher ergibt sich oft eine Mischung aus remote und on-site Tätigkeiten, wie es auch beim Projekt Marubeni der Fall war. Auch wenn die Projekte vor Ort dynamischer und viel flexibler sind, ist die Bedeutung der Remote Services sehr groß. Viele Leistungen wären aufgrund der Zahl der zu bedienenden Kunden gar nicht anders realisierbar. 
Denn wenn die Mitarbeiter remote arbeiten, können sie mehrere Kunden gleichzeitig betreuen. Wegen der entfallenden Leerzeiten kann dadurch eine erheblich größere Anzahl an Projekten ausgeliefert werden. Die Folge davon ist eine deutlich höhere Effizienz. Das steigende Kostenbewusstsein vieler Unternehmungen wird daher die Nachfrage nach Remote Services steigern. Die einzige technische Voraussetzung ist die Öffnung der obligatorisch vorhandenen Serviceverbindung zu SAP.

Das Projekt mit dem Kunden Marubeni dient als anschauliches Beispiel dafür, wie ein Remote Service-Projekt erfolgreich abgewickelt werden kann. Von dieser Vorgehensweise können auch andere Unternehmungen profitieren, sofern sie folgende als erfolgskritisch identifizierten Faktoren beachten. Essentiell für den Projekterfolg war die klare Aufgabenabgrenzung und Rollenverteilung am Anfang des Projektes. Der regelmäßige Statusaustausch sicherte den gleichen Wissenstand aller Partner, was für das Vorantreiben des Projektes entscheidend war. Da Pläne und vor allem deren Einhaltung für Kunden, mit denen kein regelmäßiger persönlicher Kontakt besteht, eine große Rolle spielen, war das strukturierte Vorgehen ein weiterer Erfolgsfaktor. Der Einsatz von Mitarbeitern mit ausgeprägter interkultureller Erfahrung trug zur relativ reibungslosen Kommunikation und Zusammenarbeit der verschiedenen Partner bei. Ein positiver Umstand war zudem die Tatsache, dass der Kunde Marubeni eine international erfahrene Unternehmung ist, deren Mitarbeiter durch längere Auslandsaufenthalte mit der westlichen Kultur vertraut sind und daher zu einer weitgehend störungsfreien interkulturellen Kommunikation beitrugen.

Allerdings wurden trotz der überwiegend positiven Durchführung einige verbesserungswürdige Schwachpunkte identifiziert. Als großes Defizit wurde die Sichtbarkeit des Leistungserstellungsprozesses erkannt, welcher für den Kunden transparenter gemacht werden muss. Bislang erfolgt dieser überwiegend als Black Box, was oft Frustrationen beim Kunden hervorruft. Weiterhin sollte auf die Integration technischer, betriebswirtschaftlicher und kultureller Aspekte geachtet werden. Bisher stehen technische Aspekte deutlich im Vordergrund. Die Konflikte hervorrufenden kulturellen Aspekte werden weitgehend vernachlässigt. Da diese jedoch das Scheitern eines Projektes bewirken können, sollte hierauf zukünftig ein stärkerer Fokus gelegt werden. Dies umfasst vor allem auch die Förderung der interkulturellen Kompetenz von unerfahrenen Mitarbeiten. 


\section{Literaturverzeichnis}

Anschütz, S. (2003): System anpassen, Kosten senken. http://www.sap.info/public/DE/ de/printout/article/Category-12613c61affe7a5bc-de/-1, Zugriff am 12. Juli 2006.

Bornemann, M., Hagemann, B. \& Kießlich, U. (2005): SAP AG, in: Ernst, H./Glänzer, S./Witt, P. (Hrsg.): Success Factors of Fast Growing Companies, Wiesbaden: Gabler, S. 217-238.

Brandt, W. \& Hütten, C. (2003): Die Finanzberichterstattung international börsennotierter Unternehmen im Licht der jüngsten Entwicklungen - Das Beispiel SAP, in: Zeitschrift für betriebswirtschaftliche Forschung, 55. Jg., 11, S. 707-721.

Holtbrügge, D. \& Schillo, K. (2006): Virtuelle Auslandsentsendungen, in: Wirtschaftswissenschaftliches Studium (WiSt), 35. Jg., 6, 2006, S. 320-324.

Holtbrügge, D. \& Schillo, K. (2007): Virtuelle Auslandsentsendungen. Konzeptionelle Grundlagen, Anwendungsbeispiele und Bewertung, in: Holtbrügge, D., Holzmüller, H.H. \& Wangenheim, F. v. (Hrsg.): Remote Services. Neue Formen der Internationalisierung von Dienstleistungen, Wiesbaden: Deutscher Universitäts-Verlag, S. 27-36.

Holtbrügge, D. \& Schillo, K. (2008): Intercultural Training Requirements for Virtual Assignments: Results of an Explorative Empirical Study, in: Human Resource Development International, Vol. 11, 3, p. 271-286.

Kaufmann, L., Michel, A., Brand, N., Finke, J., Kreft, S., Marschall von Bieberstein, B. (2005): SAP: Staying One Step Ahead, Arbeitsbericht, WHU, Koblenz.

Keller, N.V., Schumann, J.H., Wangenheim, F. v. \& Holzmüller, H.H. (2006): Die betriebswirtschaftliche Seite von ferngesteuerten Dienstleistungen - ein Problemaufriss, Arbeitsbericht Nr. 16, Lehrstuhl für Marketing der Universität Dortmund, Dortmund.

Kroker, M., Turi, P. \& Hohensee, M. (2006): Kampf der Kulturen, Wirtschaftswoche, o.Jg., 12, S. 58-64.

Lapin, S., Newson, E. \& Mallett, D. (1999): A note on SAP AG, Arbeitsbericht, Richard Ivey School of Business.

Marubeni (2006): www.marubeni.com

o.V. (2006): SAP investiert eine Milliarde Dollar in Indien, http://www.heise.de/newsticker/meldung/76315, Zugriff am 5. Oktober 2006.

Oswald, G. (2006): SAP Service und Support, 3. Aufl., Bonn: Galileo Press.

SAP (2005): SAP Customer Success Story Retail, http://www.sap.com/industries/wholesaledistribution/pdf/CS_Marubeni.pdf

SAP (2006a): Geschäftsbericht 2005, Walldorf.

SAP (2006b): SAP Labs: Creating Knowledge, Driving Innovation, Achieving Results, http:// www.sap.com/company/saplabs/index.epx, Zugriff am 1. September 2006.

Speyerer, J. (2005): Flexible Integration der Informationsverarbeitung im Supply Chain Management mit Web Services unter besonderer Berücksichtigung von Logistikdienstleistern, Berlin: Dissertationen.de.

Welge, M.K. \& Holtbrügge, D. (2006): Internationales Management, 4. Aufl., Stuttgart: Schäffer-Poeschel. 


\section{Kapitel 6 \\ Problemfelder virtueller Auslandsentsendungen. Ergebnisse einer empirischen Studie. ${ }^{1,2}$}

\section{Gliederung}

6.1 Problemstellung, Zielsetzung und Aufbau des Beitrages

6.2 Aufbau und Ablauf der empirischen Studie

6.3 Probleme virtueller Auslandsentsendungen

6.3.1 Kommunikation

6.3.1.1 Interkulturelle Kommunikation

6.3.1.2 Medial vermittelte Kommunikation

6.3.2 Unterschiede im Zeitverständnis

6.3.2.1 Termine und Deadlines

6.3.2.2 Zeithorizont

6.3.3 Vertrauen

6.3.4 Führung auf Distanz

6.3.4.1 Soziale Präsenz

6.3.4.2 Kontrolle von Mitarbeitern

6.3.4.3 Motivation von Mitarbeitern

6.3.4.4 Mentoring von Mitarbeitern

6.4 Zusammenfassung und Implikationen

$1 \quad$ Autoren: Daniel Grundgreif, Dirk Holtbrügge \& Katrin Schillo.

2 Veröffentlicht in Remote Services. Neue Formen der Internationalisierung von Dienstleistungen, hrsg. v. D. Holtbrügge, H. Holzmüller \& F. v. Wangenheim. Wiesbaden: Deutscher Universitäts-Verlag, 2007, S. 41-64. 


\subsection{Problemstellung, Zielsetzung und Aufbau des Beitrages}

Eine der wichtigsten Implikationen von Remote Services ist, dass Fach- und Führungskräfte der Muttergesellschaft nicht mehr ins Ausland entsandt werden, sondern im Heimatland verbleiben und von dort aus in Form einer virtuellen Auslandsentsendung mit Mitarbeitern, Kunden, Lieferanten und Kooperationspartnern im Gastland interagieren (vgl. Holtbrügge \& Schillo, 2007). Als virtueller Auslandsentsandter wird ein Mitarbeiter bezeichnet, „der sich physisch im Heimatland aufhält, jedoch vor allem mit Personen in anderen Ländern zusammenarbeitet" (Holtbrügge \& Schillo, 2006, S. 322). Weitere Kennzeichen von virtuellen Auslandsentsendungen sind die kulturelle und sprachliche Trennung sowie die hauptsächlich über elektronische Informations- und Kommunikationstechnologien verlaufende Interaktion. Darüber hinaus sind diese durch ein Weisungsrecht des virtuellen Auslandsentsandten gegenüber seinen Mitarbeitern im Ausland sowie ein Entscheidungsrecht gegenüber Kunden, Lieferanten oder Kooperationspartnern gekennzeichnet.

Die Vorteile virtueller Auslandsentsendungen gegenüber traditionellen Formen der Stellenbesetzung im Ausland bestehen vor allem in der Reduzierung von Reisezeiten und -kosten sowie in der Flexibilisierung des Personaleinsatzes. Virtuelle Entsandte können zudem ihr gewohntes Lebensumfeld beibehalten, wodurch familiäre und soziale Probleme reduziert werden. Diesen Vorteilen stehen jedoch zahlreiche Herausforderungen gegenüber, die sich insbesondere durch die elektronisch vermittelte Kommunikation über Landes-, Kultur- und Sprachgrenzen ergeben (vgl. Holtbrügge \& Schillo, 2006; Iten, 2001; Welch et al., 2003).

Bislang ist jedoch noch offen, ob diese in der Literatur genannten Probleme in der Unternehmungspraxis tatsächlich relevant sind und welche Bedeutung diese haben. Die Zielsetzung dieses Beitrages ist deshalb die Identifizierung und Analyse von möglichen Problemen, die bei der virtuellen Entsendung von Mitarbeitern entstehen können. Dazu wurden Mitarbeiter von international tätigen Unternehmen befragt, die bereits Erfahrungen mit virtuellen Auslandseinsätzen gesammelt haben oder sich aktuell in einem solchen befinden.

Im Folgenden wird zunächst der Ablauf der empirischen Studie erläutert. Die wichtigsten Ergebnisse werden im dritten Abschnitt dargestellt. Abschließend erfolgen eine kurze Zusammenfassung sowie die Ableitung von Implikationen für die Unternehmenspraxis sowie für die zukünftige Forschung.

\subsection{Aufbau und Ablauf der empirischen Studie}

Das Ziel der Untersuchung besteht darin, mögliche Problemfelder virtueller Auslandsentsendungen zu analysieren. Dazu wurde ein Fragebogen mit 36 geschlossenen Fragen entwickelt, die aus den vorliegenden theoretischen und empirischen Studien zu virtuellen Auslandsentsendungen und virtuellen Teams abgeleitet wurden (vgl. Gibson \& Manuel, 2003; Hertel, Geister 
\& Konradt, 2005; Holtbrügge \& Schillo, 2006; Kayworth \& Leidner, 2000; Welch et al., 2003). Den Befragten wurde eine Liste möglicher Probleme vorgelegt, deren Häufigkeit und Relevanz sie auf einer fünfstufigen Likertskala bewerten sollten. Am Ende stand eine offene Frage, in der die Befragten die Möglichkeit hatten, Probleme zu nennen, denen sie selbst in der Praxis begegnet sind, die in dieser Form aber im Fragebogen nicht aufgeführt waren. Weitere Fragen bezogen sich auf die Art der virtuellen Tätigkeit der Befragten, ihre nationale Herkunft, die organisationale Zuordnung ihrer Interaktionspartner sowie die Art der zur Interaktion verwendeten Kommunikationsmedien. Am Ende des Fragebogens wurden schließlich verschiedene demografische Daten der Teilnehmer (Geschlecht, Alter, Nationalität und deren Position im Unternehmen) abgefragt. Da bei der Befragung eine deutsche Perspektive eingenommen werden sollte, war der Fragebogen in deutscher Sprache verfasst und an deutsche Befragte gerichtet.

Zur Identifikation von geeigneten Untersuchungsteilnehmern, die über ausreichende Erfahrungen mit virtuellen Auslandsentsendungen verfügen, wurde auf die Internetplattform „openBC“ (die mittlerweile in „XING“ umbenannt wurde) zurückgegriffen. Diese speziell für Geschäftsleute konzipierte Plattform mit weltweit 1,45 Mio. Nutzern (vgl. XING, 2006) erlaubt eine gezielte Suche nach der Position bzw. Tätigkeit ihrer Mitglieder. Durch die Eingabe der Suchbegriffe ,virtuell“, „,international“ und ,global““ wurden potenzielle Teilnehmer identifiziert und persönlich angeschrieben.

Insgesamt wurde der Fragebogen als Hyperlink per E-Mail bzw. Nachricht in openBC an knapp 470 Personen verschickt und dabei die Bitte geäußert, ihn an weitere in Frage kommende Personen weiterzuleiten. Vor dem Hintergrund der Möglichkeit zur einfachen Weiterversendung des Fragebogens ist daher nicht eindeutig feststellbar, wie viele Personen ihn schließlich erhalten haben. Jedoch ist von einer weit höheren Zahl als den 470 direkt angeschriebenen Personen auszugehen. Von den verschickten Fragebögen wurden 108 geöffnet, die Beendigungsquote lag bei rund 55 Prozent. Daraus ergibt sich eine gesamte Teilnehmerzahl bzw. Stichprobe von 59 vollständig ausgefüllten Fragebögen. Diese auf den ersten Blick niedrige Zahl muss vor dem Hintergrund der relevanten Grundgesamtheit gesehen werden. Zwar ist die Zahl von virtuellen Auslandsentsandten unbekannt, es kann jedoch aufgrund der existierenden Literatur und den praktischen Erfahrungen bei der Suche nach Befragungsteilnehmern geschlossen werden, dass diese (noch) relativ gering ist. Auch aus der vergleichsweise kleinen Stichprobe können deshalb repräsentative Schlüsse gezogen werden.

\subsection{Probleme virtueller Auslandsentsendungen}

Abbildung 6-1 gibt einen Überblick über die Häufigkeit des Auftretens unterschiedlicher Probleme virtueller Auslandsentsendungen aus Sicht der Befragten, während in Abbildung 6-2 die wahrgenommene Bedeutung dieser Probleme dargestellt ist. Die Abkürzung „VE“ steht dabei für „virtueller Entsandter“ und „IP“ für „Interaktionspartner“. 


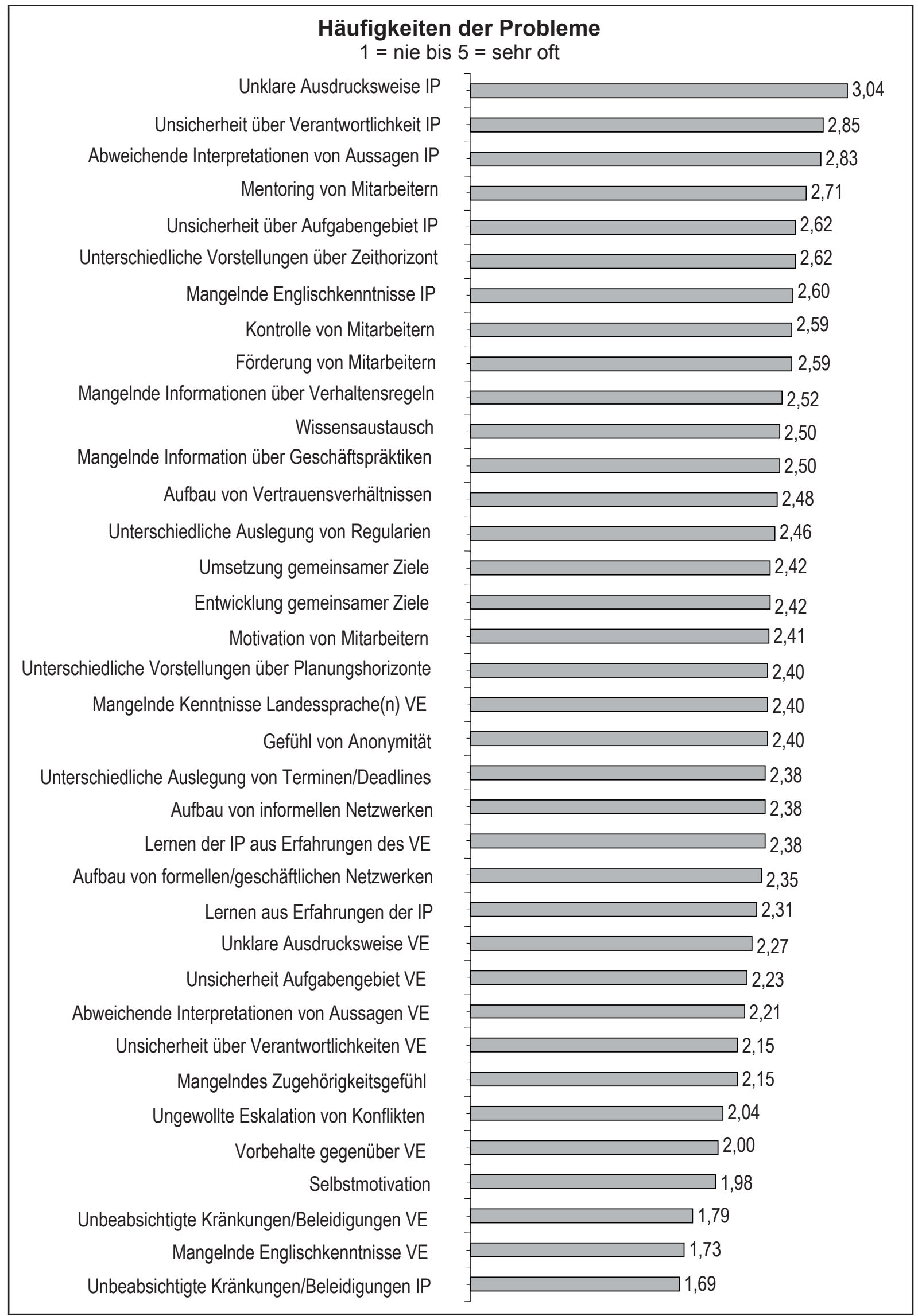

Abbildung 6-1: Probleme virtueller Auslandsentsendungen (Häuftigkeiten) 


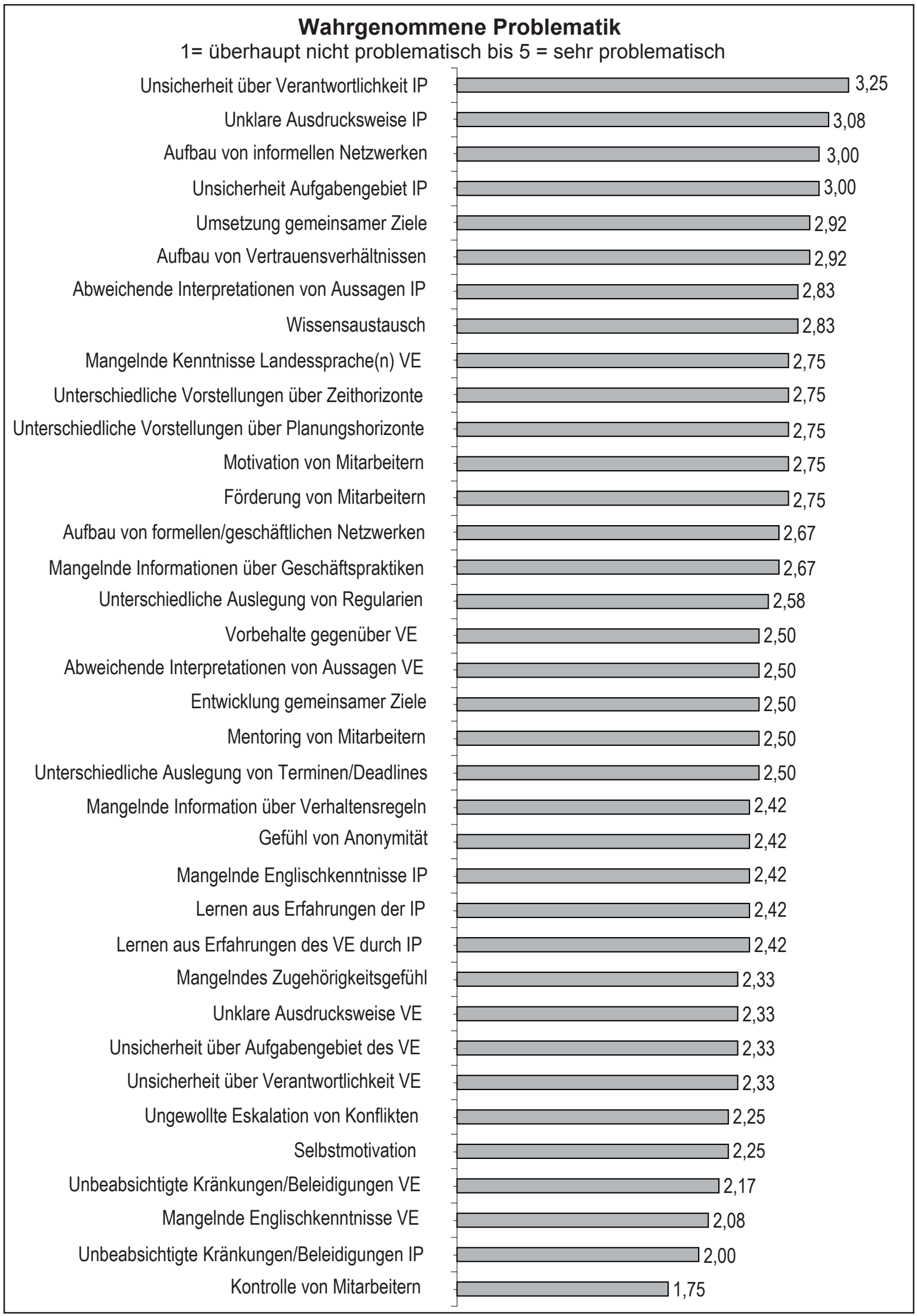

Abbildung 6-2: Probleme virtueller Auslandsentsendungen (Bedeutung) 
Systematisiert man die von den Befragten angeführten Probleme und deren Bedeutung, so können diese vier Problemfeldern zugeordnet werden (vgl. Abb. 6-3). Diese Problemfelder sind häufig nicht unabhängig voneinander, sondern interdependent. So beeinflussen etwa die unterschiedlichen Zeitverständnisse der Interaktionspartner sowohl die Kommunikation, die Führung auf Distanz als auch den Aufbau und die Aufrechterhaltung von Vertrauen zwischen den Interaktionspartnern. Gleiches gilt für die geographische Entfernung der Interaktionspartner und die daraus resultierende Notwendigkeit der Nutzung von elektronischen Kommunikationsmedien. Mögliche Probleme sind also zumeist nicht allein auf einen der genannten Bereiche zurückzuführen, sondern entstehen vielmehr aus einem Zusammenspiel der einzelnen Problembereiche.

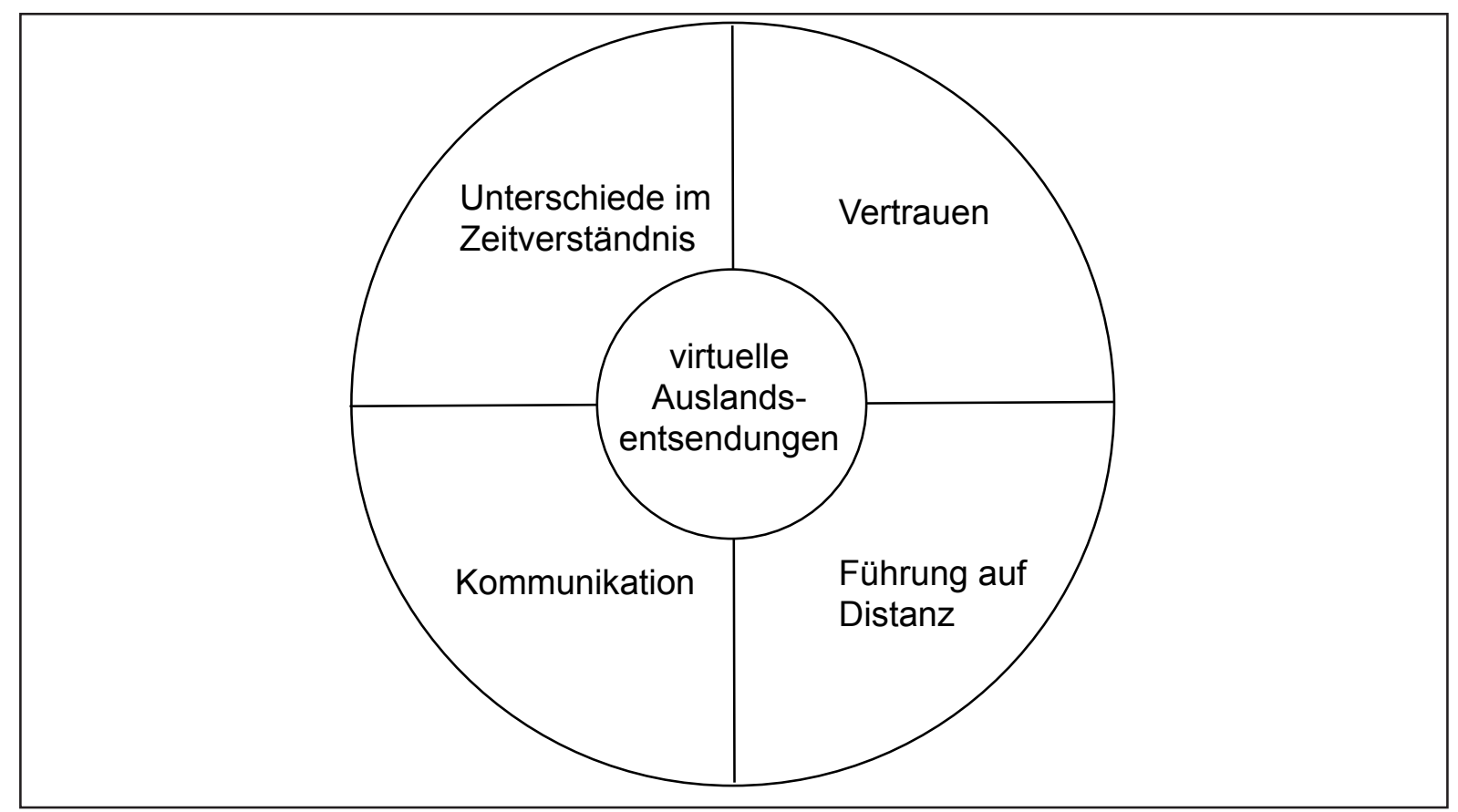

Abbildung 6-3: Problemfelder bei virtuellen Auslandsentsendungen

\subsubsection{Kommunikation}

\subsubsection{Interkulturelle Kommunikation}

Ein zentraler Problembereich bei virtuellen Auslandsentsendungen ist die Kommunikation des Entsandten mit seinen Interaktionspartnern. Knapp (2003, S. 109) zeigt, dass im Schnitt 70 Prozent der Arbeitszeit von Managern aus Kommunikation besteht (vgl. auch Kikoski, 1993, S. 84). Bei einer virtuellen Auslandsentsendung, bei der die Zusammenarbeit zum größten Teil über die medial vermittelte Kommunikation erfolgt, ist anzunehmen, dass dieser Anteil sogar noch höher ausfällt. Das Problempotenzial ergibt sich dabei aus dem Umstand, dass die Kommunikation zwischen Partnern mit verschiedenen kulturellen Hintergründen stattfindet. Thomas (2003, S. 101 f.) definiert eine solche interkulturelle Kommunikation als „Kommunikation 
(...) unter kulturellen Überschneidungsbedingungen, wobei die kulturellen Unterschiede der Partner maßgeblich das Kommunikationsgeschehen sowohl hinsichtlich der Ablaufprozesse als auch der Resultate beeinflussen.“

Generell setzen in einem internationalen Kontext zentrale Aktivitäten wie etwa der Austausch von Informationen und Ideen, das gemeinsame Treffen von Entscheidungen, das Führen von Verhandlungen oder die Führung und Motivation von Mitarbeitern die Fähigkeit voraus, erfolgreich mit Angehörigen anderer Kulturen zu kommunizieren (vgl. Adler, 2003, S. 247). Dies gilt in besonderer Weise für virtuelle Auslandsentsandte. „Bei virtuellen Auslandseinsätzen liegen die Gefahren des Scheiterns nicht in der ungenügenden Beherrschung technischer Systeme, sondern darin, dass sich die Gesprächspartner aufgrund kultureller Unterschiede nicht verstehen können" (Iten, 2000, S. 206). Ursächlich dafür können vor allem kulturbedingte Interpretationsprobleme, mangelnde Sprachkenntnisse sowie unterschiedliche Kontextorientierungen sein.

\subsection{Kulturbedingte Interpretationsstörungen}

Beamer (1992, S. 285 ff.) zeigt in anschaulicher Weise den beim Empfänger einer Botschaft eines Senders aus einer fremden Kultur ablaufenden Prozess. Sie greift dabei auf das der Semiotik entstammende Konzept des „signifier“ und „signified“ zurück. Danach setzt sich eine Botschaft oder ein Signal aus einem Signifier (also dem Träger der Botschaft, beispielsweise einem Wort oder einem Satz) und dem Signified (also der dem Signifier zugeordneten Bedeutung) zusammen. Bei der Zuordnung der Bedeutung des Signifiers greift der Empfänger auf seinen aufgrund seines kulturellen Hintergrundes determinierten Vorrat an Bedeutungen bzw. sein „reservoir of signs““ (S. 288) zurück. Grafisch wird dieser Vorgang in Abbildung 6-4 dargestellt.

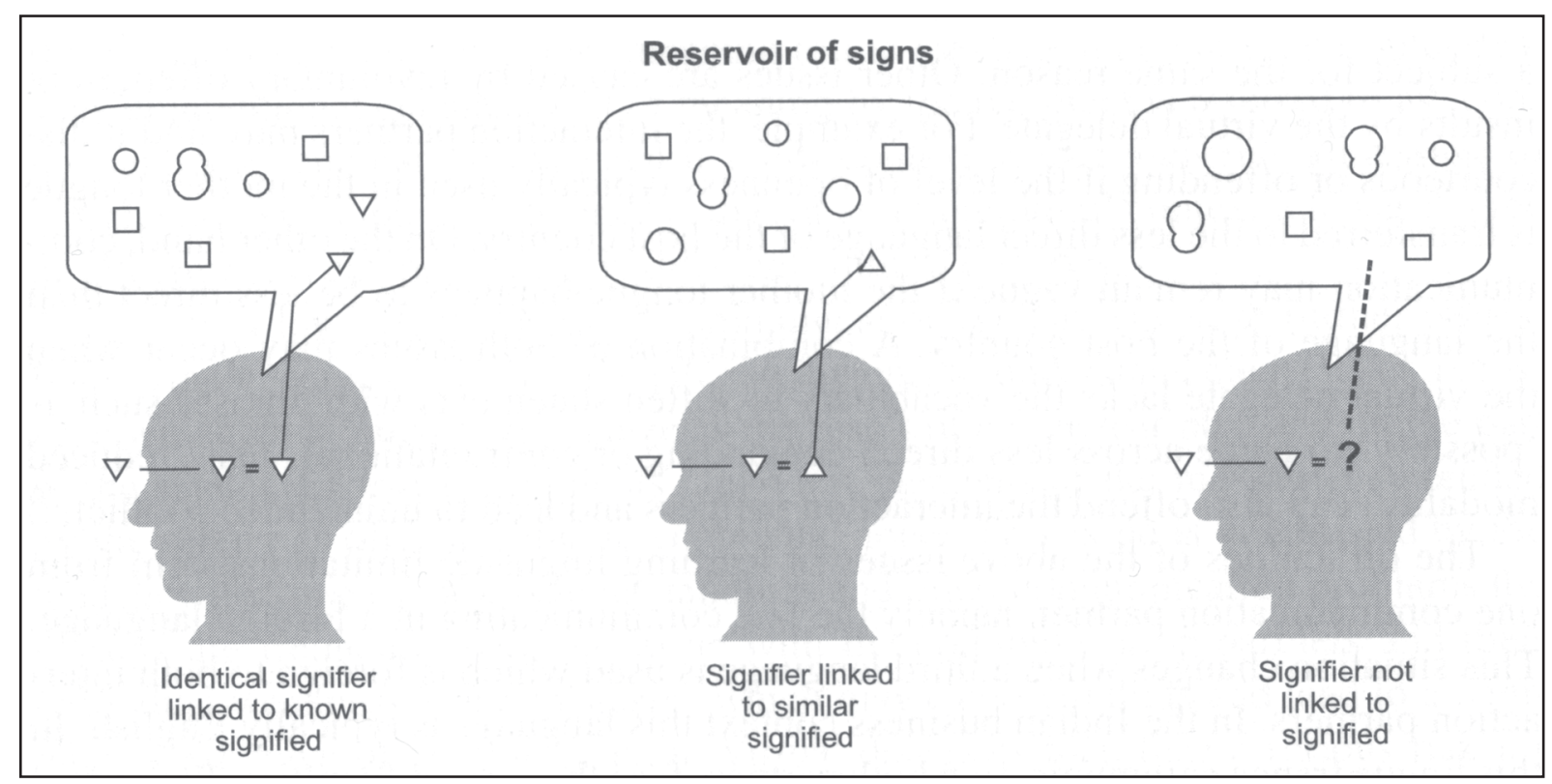

Abbildung 6-4: Zuordnung von Signifier zu Signified

Quelle:

Beamer, 1992, S. 288. 
Im ersten Fall findet eine effektive Kommunikation statt. Der Empfänger kennt den Signifier und ordnet ihn der vom Sender beabsichtigten Bedeutung zu. Im zweiten Fall kennt der Empfänger zwar den empfangenen Signifier, nicht aber seine exakte Bedeutung. Er ordnet ihn jedoch einer in seinem Vorrat enthaltenen ähnlichen Bedeutung zu. In einem solchen Fall entstehen Missverständnisse, die zu ineffektiver Kommunikation und Konflikten führen können. Im dritten Fall kommt keine Kommunikation zustande, da der Empfänger die empfangene Botschaft keiner ihm bekannten oder dieser ähnlichen Bedeutung zuordnen kann (vgl. Beamer, 1992, S. 287 ff.).

Die Problematik der Kommunikation bei virtuellen Auslandsentsendungen besteht darin, dass der Codierungs- und der Decodierungsprozess nicht unter gleichen, sondern unter kulturell unterschiedlichen Bedingungen stattfindet: „Translating meanings into words and behaviors - that is, into symbols - and back again into meanings is based on a person's cultural background and is not the same for each person“ (Adler, 2003, S. 249). Die Wahrscheinlichkeit, dass die vom Sender beabsichtigte Botschaft nicht in der gewünschten Form beim Empfänger ankommt und interpretiert wird, ist dabei umso höher, je größer die kulturelle Distanz zwischen den Kommunikationspartnern ist (vgl. Adler, 2003, S. 249; Konopaske \& Ivancevich, 2004, S. 150).

\subsection{Mangelnde Sprachkenntnisse}

Eine weitere Ursache für eine abweichende Codierung und Decodierung einer Botschaft kann die Benutzung unterschiedlicher Signifier oder kommunikativer Codes in Form von Sprache sein (vgl. Knapp, 2003, S. 113). Bei einer Kommunikation zwischen Angehörigen unterschiedlicher Kulturen ist davon auszugehen, dass sich mindestens einer der Kommunikationspartner nicht seiner eigenen Muttersprache bedienen kann. Im Fall einer virtuellen Auslandsentsendung ist es mit hoher Wahrscheinlichkeit der Entsandte, der in der ihm fremden Sprache, nämlich der Sprache des Gastlandes, kommunizieren muss. Laut Thomas (2003, S. 104) ist „die Beherrschung der Sprache der Gastlandbewohner eine Grundvoraussetzung dafür, dass interkulturelle Kommunikation auf hohem Niveau überhaupt stattfinden kann.“ Ein solches ,fremdsprachliches Kommunizieren“ bedingt nach Knapp (2003, S. 113) jedoch „eine weit höhere Komplexitätsstufe mit höheren Risiken für die Verständigung“ als dies bei einer Kommunikation zwischen Individuen mit der gleichen Muttersprache der Fall wäre. Dies gilt für virtuelle Auslandsentsendungen in besonderem Maße, da die Kommunikation dabei überwiegend mit Hilfe elektronischer Medien stattfindet, die im Vergleich zur persönlichen Kommunikation eine weitaus geringere Reichhaltigkeit aufweisen.

Die Kommunikation in der Sprache des Gastlandes kann für den virtuellen Entsandten Schwierigkeiten mit sich bringen, da er in ihrer Verwendung so genannten ,lernersprachlichen Beschränkungen“ (Knapp, 2003, S. 121) unterworfen ist. So kann seine Ausdrucksweise von seinen Interaktionspartnern als unklar wahrgenommen werden, wenn ihm der notwendige Wortschatz zur differenzierten Darstellung eines Sachverhaltes fehlt oder er aus demselben Grund 
bestimmte Themen gänzlich vermeidet. Ein weiteres Problem sind unbeabsichtigte Kränkungen und Beleidigungen durch den virtuellen Entsandten. Überträgt dieser beispielsweise den in seiner Muttersprache üblichen Grad an Direktheit auf die weniger direkte Gastlandsprache, so kann dies unter Umständen von seinem Interaktionspartner als unhöflich oder beleidigend empfunden werden. Andererseits besteht auch die Möglichkeit, dass die Ausdrucksweise als unklar wahrgenommen wird, wenn der Direktheitsgrad der Muttersprache geringer ist als der der Gastlandsprache. Eine Kombination der beiden Probleme tritt auf, wenn dem virtuellen Entsandten das Vokabular fehlt, um bestimmte Aussagen durch abschwächende Zusätze wie z.B. „möglicherweise“ weniger direkt, fordernd oder konfrontativ zu formulieren. Auch eine solche „Modalitätsreduktion“ kann dazu führen, dass sich der Interaktionspartner gekränkt oder beleidigt fühlt, was wiederum ungewollte Konflikte nach sich ziehen kann (vgl. Knapp, 2003, S. 121 f.).

Bei den oben beschriebenen Problemen aufgrund lernsprachlicher Beschränkungen geht die Problematik von einem der beiden Kommunikationspartner aus, nämlich demjenigen, der in der ihm fremden Sprache kommunizieren muss. Diese Situation ändert sich, wenn zur Kommunikation eine dritte, beiden Interaktionspartnern fremde Sprache verwendet wird. In einem internationalen Wirtschaftskontext ist diese Sprache üblicherweise Englisch. In einer solchen Lingua-Franca-Kommunikation sehen sich beide Kommunikationspartner denselben Schwierigkeiten gegenüber. Für den virtuellen Entsandten mag dies zunächst eine gewisse Erleichterung bedeuten, sofern seine Englischkenntnisse besser sind als die Kenntnisse der Gastlandsprache. Auch das subjektive, möglicherweise als belastend empfundene Bewusstsein, aufgrund der mangelnden Sprachkenntnisse selbst der Grund für Missverständnisse zu sein, wird dadurch abgeschwächt. Gleichzeitig bedeutet die Kommunikation in englischer Sprache jedoch (soweit diese für keinen der Kommunikationspartner die Muttersprache ist), dass nun mehrere Quellen für sprachliche Missverständnisse existieren, da eine perfekte Beherrschung des Englischen auf beiden Seiten nicht vorausgesetzt werden kann (vgl. Knapp, 2003, S. 122 f.). „Selbst wenn man unterstellt, dass beide Partner die Drittsprache ausgezeichnet beherrschen, muss man davon ausgehen, dass die interkulturelle Kommunikation in diesem Fall schon nicht mehr auf einem sehr hohen Niveau möglich ist" (Thomas, 2003, S. 104).

\subsection{Unterschiedliche Kontextorientierung}

Eine weitere Quelle für interkulturelle Kommunikationsprobleme ist nach unserer Untersuchung die Menge an in einer Botschaft enthaltenen Informationen. Hall (1981, S. 85 ff.) unterscheidet in seinem Konzept der Kontextorientierung zwischen ,high-context" und „low-context“-Kulturen. In High-Context-Kulturen ist nur ein sehr geringer Teil an Informationen in der explizit formulierten Botschaft enthalten, sondern vor allem im Kontext der Kommunikation verborgen. In Low-Context-Kulturen enthalten Botschaften dagegen ein hohes Ausmaß an unmittelbaren Informationen, d.h. die Botschaft wird direkt und unmittelbar sprachlich geäußert. 
Welche Probleme aufgrund verschiedener Kontextorientierung der Kommunikationspartner auftreten können, zeigen Kittler et al. (2006, S. 7 ff.) in einem integrierten Modell interkultureller Kommunikation. So kann eine unterschiedliche Kontextorientierung dazu führen, dass ein Teil der vom Sender beabsichtigten Botschaft vom Empfänger nicht als solche identifiziert wird und somit im Kommunikationsprozess verloren geht. Ein solcher Verlust wird als „,contextual loss“ bezeichnet. Contextual loss ist dann zu erwarten, wenn der Sender der Botschaft eine hohe, der Empfänger jedoch eine geringe Kontextorientierung besitzt. Im umgekehrten Fall besteht auch die Möglichkeit, dass der Empfänger der Botschaft mehr Bedeutung und Informationen zuweist als vom Sender beabsichtigt. Ein solches unbeabsichtigtes Hinzufügen von Bedeutung zu einer Botschaft durch deren Empfänger wird als „,contextual noise“ bezeichnet und ist dann zu erwarten, wenn ein Low-Context-Sender eine Botschaft an einen High-Context-Empfänger übermittelt. Als Konsequenz ergibt sich im Bezug auf interkulturelle Kommunikation: „A lower degree of effectiveness can be caused by different cultural contexts“ (Kittler et al., 2006, S. 10).

Neben einer geringeren Effektivität der Kommunikation sind noch weitere Probleme vorstellbar. So könnten beispielsweise durch contextual loss vom Empfänger nicht wahrgenommene Teile einer Botschaft von diesem als Ergebnis einer unklaren Ausdrucksweise seines Kommunikationspartners ausgelegt werden. Ebenso könnten durch contextual noise vom Sender unbeabsichtigte Teile der Botschaft vom Empfänger als Kränkung oder Beleidigung interpretiert werden. Besonders problematisch ist dies vor dem Hintergrund, dass bei Missverständnissen und anderen Kommunikationsproblemen die Tendenz besteht, die Ursachen für diese Probleme in der Person des Kommunikationspartners bzw. dessen Schwächen und Fehlern zu sehen. Dies kann zu Konflikten und im schlimmsten Fall zum gänzlichen Abbruch des Kontakts führen (vgl. Thomas et al., 2006, S. 93 f.; Thomas, 2003, S. 102 f.). Für einen virtuellen Auslandsentsandten bedeutet dies eine Gefährdung der Beziehungen zu seinen Interaktionspartnern und somit die Gefahr der Beeinträchtigung des Erfolgs seines Einsatzes.

\subsubsection{Medial vermittelte Kommunikation}

\subsection{Beschränkungen medial vermittelter Kommunikation}

Neben den kulturellen Unterschieden der Interaktionspartner ist eines der zentralen Merkmale von virtuellen Auslandsentsendungen die geographische Trennung zwischen der physischen und der virtuellen Arbeitswelt. Daraus resultiert die Notwendigkeit einer hauptsächlich über elektronische Informations- und Kommunikationstechnologien stattfindenden Interaktion und Kommunikation (vgl. Holtbrügge \& Schillo, 2006, S. 322).

Zahlreiche Autoren weisen im Zusammenhang von virtuellen Teams auf die Probleme medial vermittelter Kommunikation hin (vgl. Gibson \& Manuel, 2003, S. 61; Roebuck et al., 2004, S. 360; McKinney \& Whiteside, 2006, S. 85; Rosen et al., 2006, S. 231). Als das größte Pro- 
blem wird dabei die mangelnde Fähigkeit elektronischer Kommunikationsmedien gesehen, die Elemente einer Botschaft, die über die verbale Ebene, also das gesprochene bzw. geschriebene Wort hinausgehen, in adäquater Weise zu übermitteln. So stellen beispielsweise Kayworth und Leidner (2000, S. 187) fest, dass ,information technology has limits and may not be able to transfer the same rich social, emotional, and non-verbal information present in traditional faceto-face settings (...). For example, information rich non-verbal cues such as facial expressions, voice inflections, and gestures, normally present in traditional settings, may be lost or distorted through computer mediated communication systems." Wie wichtig jedoch gerade die non- und para-verbalen Elemente einer Botschaft sind, zeigt Mehrabian (1972, S. 108). Dieser fand heraus, dass die Bedeutung einer Aussage nur zu 7 Prozent über die verbale Ebene vermittelt wird. 38 Prozent der Aussage werden dagegen über para-verbale Elemente (z.B. Intonation und Lautstärke) und 55 Prozent über non-verbale Elemente (Mimik, Gestik oder Körperhaltung) übertragen.

Da elektronische Informations- und Kommunikationsmedien die beschriebenen para- und nonverbalen Elemente von Botschaften nicht oder nur eingeschränkt übermitteln können, steigt das Potenzial für Missverständnisse und Konflikte zwischen den Kommunikationspartnern an. So lässt beispielsweise in einer Face-to-Face stattfindenden Kommunikation die Mimik und Gestik des Empfängers einer Botschaft Rückschlüsse darauf zu, ob er die gesendete Botschaft verstanden hat oder nicht (vgl. Roebuck et al., 2004, S. 360). Hat der Sender die Möglichkeit, die vom Empfänger gesendeten Signale wahrzunehmen und zu deuten, kann er die nicht oder falsch verstandene Botschaft verdeutlichen oder berichtigen und somit einem Missverständnis vorbeugen. Ein solches korrektives Feedback ist bei medial vermittelter Kommunikation, wie sie für virtuelle Entsandte typisch ist, nicht oder nur eingeschränkt möglich. Weiteres Konfliktpotenzial birgt der Umstand, dass emotionale Komponenten der Kommunikation, wie etwa Humor, Ärger oder Frustration, nur schwer medial vermittelbar sind (vgl. Rosen et al., 2006, S. 231). Wird beispielsweise die humorvolle Intention einer Botschaft vom Empfänger aufgrund fehlender para- oder non-verbaler Informationen nicht als solche oder falsch interpretiert, kann dies dazu führen, dass sich dieser vom Sender unbeabsichtigt gekränkt oder beleidigt fühlt. Verstärkt wird das Kommunikationsproblem dadurch, wenn der Sender der Botschaft wiederum den Ärger des Empfängers nicht als solchen wahrnimmt und somit keine Notwendigkeit zur Richtigstellung seiner eigentlichen Intention erkennt.

Eine wichtige Einflussgröße auf das Ausmaß der auftretenden Probleme und Konflikte ist der Grad an „media richness“ der verwendeten Kommunikationsmedien. Nach der Media Richness-Theorie unterscheiden sich verschiedene Kommunikationsmedien nach den „levels of richness according to the number of cues they are able to convey, the timeliness of the feedback and the capacity of natural expression" (Warkentin \& Beranek, 1999, S. 274). Je höher also die Media Richness eines Kommunikationsmediums ist, desto geringer sind die Missverständnisse und Konflikte, die aufgrund seiner Nutzung zur Kommunikation zu erwarten sind. McKinney und Whiteside (2006, S. 82 ff.) zeigen, dass Videokonferenzen im Vergleich zu anderen Kom- 
munikationsmedien (abgesehen von der traditionellen Face-to-Face-Kommunikation) über die höchste Media Richness verfügen. Die anderen untersuchten Medien sind, abnehmend nach ihrem Grad an Media Richness, das Telefon, E-Mail, Fax und der traditionelle Brief.

Eine Studie von IBM Business Consulting Services (2005, S. 4) zeigt jedoch, dass das Kommunikationsmedium mit der höchsten Media Richness in der Praxis nur eine geringe Verbreitung besitzt. In einer Befragung von 351 remote arbeitenden Personen aus 29 europäischen Ländern gaben lediglich 9 Prozent der Befragten an, das Medium Videokonferenz oft oder sehr oft zu nutzen. Als äußerst weit verbreitet stellten sich dagegen die Nutzung von Telefon bzw. Telefonkonferenzen mit 85 Prozent und vor allem die Nutzung von E-Mails mit 95 Prozent zur Interaktion mit geographisch entfernten Kollegen heraus. Während das Telefon als Kommunikationsmedium die Fähigkeit besitzt, neben der verbalen Botschaft auch para-verbale Elemente zu übertragen und somit die Gefahr für Missverständnisse und Konflikte zumindest in einem gewissen Maße einschränkt, ist diese Gefahr bei der Kommunikation via E-Mail als besonders groß einzuschätzen.

Auch die vorliegende Studie zeigt, dass mit der Kommunikation via E-Mail ein Kommunikationsmedium die meiste Verwendung findet, das über einen geringen Grad an Media Richness verfügt. Dieser Umstand kann als eine mögliche Erklärung für die hohe Einstufung der Probleme ,unklare Ausdrucksweise“ und ,abweichende Interpretationen von Aussagen auf Seiten der Interaktionspartner" als auch für andere Kommunikationsprobleme wie etwa die fehlende Möglichkeit zum Wissensaustausch dienen. Bemerkenswert ist der relativ hohe Anteil an Faceto-Face-Kommunikation, der auf regelmäßige Treffen der Interaktionspartner und eine damit verbundene vermehrte Reisetätigkeit der Befragten schließen lässt. Auch fällt auf, dass neuartige Kommunikationsmedien wie Videokonferenzen oder Net-Meetings kaum verbreitet sind.

Neben der bereits dargestellten Problematik der fehlenden Übertragung sowohl para- als auch non-verbaler Elemente weisen Friedman und Currall (2003, S. 1338 ff.) auf zwei weitere Problemquellen der E-Mail-Kommunikation hin. So bieten E-Mails die Möglichkeit, sich längere Zeit mit der empfangenen Botschaft zu beschäftigen, als das bei einer anderen Form der Kommunikation der Fall wäre. Durch ein wiederholtes Lesen und Reflektieren der Botschaft besteht die Möglichkeit, dass etwaige enthaltene Probleme in der Wahrnehmung des Empfängers an Ausmaß zunehmen und sich somit die Wahrscheinlichkeit einer Lösung des Problems verringert. Weiterhin birgt der relativ lange Zeitraum, der zum Verfassen einer E-Mail in Anspruch genommen werden kann, die Gefahr, dass sich der Standpunkt des Verfassers durch eine ausführliche Auseinandersetzung mit seiner Botschaft bzw. seinen Argumenten verfestigt und somit seine Kompromissbereitschaft abnimmt. Überdies verringert das Wissen, dass dem Kommunikationspartner ebenfalls ausreichend Zeit zur bedachten und bewussten Formulierung der E-Mail zur Verfügung steht, die Tendenz, mögliche Kränkungen und Beleidigungen als zufällig und unbeabsichtigt zu bewerten. 
Zum anderen birgt auch der prinzipiell unbegrenzte Umfang von E-Mails Potenzial für Probleme. Erhält beispielsweise der Empfänger eine sehr umfangreiche E-Mail und bezieht sich in seiner Antwort, etwa aus zeitlichen Gründen, nicht auf alle in der E-Mail enthaltenen Informationen, so kann bei seinem Gegenüber der Eindruck entstehen, dass ihm bzw. seiner E-Mail nur eine geringe Priorität zugemessen wird. Weiterhin besteht die Tendenz, dass sich die Erinnerung bei einer Vielzahl von Informationen, die aufgrund einer beschränkten Wahrnehmungsfähigkeit nicht alle verarbeitet werden können, auf die Teile der Botschaft fokussiert, die beim Empfänger die stärkste, meist negative Reaktion hervorgerufen haben. Verdeutlicht wird dies durch folgende Darstellung von Friedman und Currall (2003, S. 1339): "If, say, a series of seven or eight arguments are made, but one was especially anger-provoking, then it is that most angerprovoking argument that is likely to dominate memory, overshadowing points where there was more room for constructive engagement."

\subsection{Medial vermittelte interkulturelle Kommunikation}

Die oben beschriebenen Probleme medial vermittelter Kommunikation können schon in einem monokulturellen Umfeld die Zusammenarbeit geographisch entfernter Interaktionspartner erheblich beeinträchtigen. Findet die Interaktion nun zwischen Partnern mit unterschiedlichen kulturellen Hintergründen statt, ist ein erhöhtes Ausmaß der Problematik zu erwarten. So stellen beispielsweise Blom und Meier (2002, S. 84) fest: „In interkulturellen Begegnungen werden non-verbale Signale verstärkt eingesetzt, um verbale Sprache oder Fremdsprachendefizite zu ersetzen (...). Wird Sprache nicht non-verbal unterstützt, wird diese Inkonsistenz (...) den Gesprächspartner verwirren.“ Auch Iten (2001, S. 170) sieht in der medial vermittelten interkulturellen Kommunikation ein erhöhtes Problem- und Konfliktpotenzial gegenüber traditioneller Face-to-Face-Kommunikation: „Kulturelle Missverständnisse könnten sogar noch verstärkt werden, da die beteiligten Personen über weniger sensorische Informationen verfügen.“

Wie groß die zu erwartenden Probleme medial vermittelter Kommunikation bei virtuellen Auslandsentsendungen sind, hängt auch von dem Zielland der Entsendung ab. Eine wichtige Einflussgröße ist dabei die bereits dargestellte Kontextorientierung einer Kultur. Da in HighKontext-Kulturen ein großer Teil der Bedeutung einer Botschaft über para- und non-verbale Informationen übertragen wird, ist die medial vermittelte Kommunikation mit Angehörigen solcher Kulturen als besonders schwierig einzuschätzen (vgl. Holtbrügge \& Schillo, 2006, S. 324). Auch Welch et al. (2003, S. 107) weisen auf den Umstand hin, ,that high-context cultures rely more heavily on one's ability to read the non-verbal cues than in low context cultures (...). Such cues are missing from electronic media.“ Für einen einer Low-Kontext-Kultur wie Deutschland entstammenden virtuellen Auslandsentsandten bedeutet dies, dass das zu erwartende Potenzial für Missverständnisse und Konflikte umso größer ist, je größer die Kontextorientierung der Zielkultur seiner Entsendung ist. 


\subsubsection{Unterschiede im Zeitverständnis}

Ein weiterer wichtiger Problembereich im Kontext virtueller Auslandsentsendungen ist das unterschiedliche Zeitverständnis in verschiedenen Kulturen. So stellen Bluedorn \& Denhardt (1988, S. 316) fest, dass ,every aspect of international business, from the management of joint ventures to the first meeting in any international undertaking, is permeated with temporal behaviors and potential problems and misunderstandings as a result." In der vorliegenden Untersuchung wurden Unterschiede im Zeitverständnis deshalb ebenfalls als sehr bedeutsam eingestuft. Dabei kann zwischen unterschiedlichen Auffassungen über Termine und Deadlines sowie unterschiedlichen Zeithorizonten unterschieden werden.

\subsubsection{Termine und Deadlines}

Eines der meist zitierten Zeitkonzepte ist das Konzept der monochronen (M-time) und polychronen (P-time) Zeitorientierung von Hall. Er unterscheidet die beiden Zeitauffassungen wie folgt: „M-time emphasizes schedules, segmentation, and promptness. P-time systems are characterized by several things happening at once. They stress involvement of people and completion of transactions rather than adherence to preset schedules“ (1981, S. 17). Für einen Angehörigen einer monochronen Kultur bedeutet ein Termin einen festen Zeitpunkt für eine Tätigkeit, wie etwa eine Besprechung oder eine Konferenz, den es einzuhalten gilt. Ein Termin ist ein Teil seines täglichen Zeitplanes und auf seine anderen Termine abgestimmt. Etwaige Änderungen an dem Termin oder zu erwartende Verspätungen sollten ihm möglichst frühzeitig kommuniziert werden, um diese Änderung in seine Terminplanung einbeziehen zu können (vgl. Bluedorn et al., 1992, S. 23). Für einen in einer monochron orientierten Umwelt lokalisierten virtuellen Auslandsentsandten besteht überdies die Notwendigkeit, seine Terminplanung in gewissem Umfang auch mit seinem Umfeld abzustimmen. So ist in der Praxis beispielsweise die Nutzung technischer Hilfsmittel wie etwa für eine Videokonferenz oftmals durch Benutzungs- oder Belegungspläne geregelt. Dies erfordert für den virtuellen Entsandten eine zusätzliche Planungs- und Terminsicherheit.

Ein polychroner Interaktionspartner hat dagegen mit hoher Wahrscheinlich keine vergleichbar strikte Zeitplanung: „Scheduling is difficult if not impossible with P-time people” (Hall, 1981, S. 22). Eine Verspätung oder eine kurzfristige Änderung eines Termins sieht ein Angehöriger einer polychronen Kultur deshalb als Normalität an. Für seinen monochronen Interaktionspartner bedeutet das jedoch eine Störung seines festen Zeitplanes. Er muss möglicherweise Leerlaufzeiten oder Zeitnot in Bezug auf andere Termine in Kauf nehmen oder diese verlegen bzw. absagen. Dies kann zu Ärger und Frustration beim Betroffenen führen. Beurteilt dieser die Situation nun aus seiner eigenen monochronen Perspektive heraus, wird er diese Frustration wahrscheinlich auf seinen Interaktionspartner und dessen Fehlverhalten projizieren. Behält er seinen Ärger für sich, besteht die Gefahr, dass er eine negative Grundeinstellung gegenüber seinem Interaktionspartner bildet. Kommuniziert er jedoch seinen Ärger, kann dies zu einem 
Konflikt führen, wenn sein Interaktionspartner die Situation seinerseits aus einer polychronen Perspektive heraus betrachtet. Dieser wird sich wahrscheinlich zu unrecht beschuldigt fühlen, da aus seiner Sicht überhaupt kein Problem besteht. Beide Szenarien können gleichermaßen das Verhältnis der beiden Interaktionspartner stören und somit ein effektives Zusammenarbeiten erschweren (vgl. Saunders et al., 2004, S. 24 ff.).

Ähnliches gilt auch für die Fertigstellung von Aufgaben. Auch hier legen Angehörige monochron orientierter Kulturen großen Wert auf eine präzise Zeitplanung und die Einhaltung fester Zeitvorgaben im Sinne von Deadlines. Ebenso wichtig ist für sie eine genaue Planung des Ablaufs der einzelnen Schritte oder Teilziele, die zur Erreichung des Gesamtzieles führen sollen. Angehörige polychron orientierter Kulturen hingegen planen den zeitlichen Rahmen von zu erfüllenden Aufgaben weit weniger genau oder verzichten auf eine solche Zeitplanung sogar gänzlich. Auch ihr Vorgehen zur Erreichung des Gesamtzieles ist nicht durch eine festgelegte Planung im Voraus determiniert, sondern unterliegt häufigen Änderungen in Bezug auf Arbeitsabläufe und Prioritäten bei der Aufgabenerfüllung (vgl. Bluedorn et al., 1992, S. 23). Auch hier können unterschiedliche Zeitorientierungen zu Missverständnissen und Konflikten führen und somit die Effizienz der Zusammenarbeit gefährden.

Als erschwerender Faktor für einen virtuellen Auslandsentsandten aus einer monochron orientierten Kultur (wie der deutschen) kommt bei einer Entsendung in eine polychron orientierte Kultur hinzu, dass er nur einen Teil seiner täglichen Zeit mit den Angehörigen dieser Kultur interagiert. Ihm fehlt dadurch die Möglichkeit, sich auch im täglichen Leben außerhalb seiner Arbeit an die polychrone Zeitauffassung zu gewöhnen. So wie Hall basierend auf Beobachtungen von Menschen anderer Kulturen in ihrem täglichen Handeln die Unterscheidung zwischen monochroner und polychroner Zeitauffassung entwickelt hatte, hat auch ein im Gastland lebender Auslandsentsandter die Möglichkeit, das Zeitverständnis seiner Gastkultur jeden Tag zu erleben. Der traditionelle Entsandte kann aus seinen Beobachtungen und Erfahrungen wie beispielsweise das Warten auf verspätete öffentliche Verkehrsmittel oder auf die Gäste bei einer Veranstaltung lernen, die Situation als Normalität anzusehen und sein eigenes Wahrnehmen und Verhalten daran anzupassen. Eine wichtige Konsequenz aus einem solchen Lernprozess wäre, dass der Entsandte ein bestimmtes Verhalten (das aus seiner Sicht zu späte Eintreffen zu einem Termin) nicht mehr als fehlerhaftes oder unverschämtes Verhalten der anderen Person betrachtet, sondern als Folge ihres kulturellen Hintergrundes. Hat der Entsandte einen solchen Lernprozess durchlaufen, sinkt auch das Potential von Konflikten und Missverständnissen zwischen ihm und seinen Interaktionspartnern aufgrund der unterschiedlichen Zeitvorstellungen (vgl. Bluedorn et al., 1992, S. 25).

Ein solcher Lernprozess bleibt dem virtuellen Auslandsentsandten aus einer monochronen Kultur jedoch weitgehend verwehrt. Sein Alltag findet in einem monochron orientierten Umfeld statt und ist von fest einzuhaltenden Plänen, Terminen und Zeiten geprägt. Dieses Umfeld gibt ihm also kaum Anlass, sich über seine eigene Zeitorientierung bewusst zu werden. Das glei- 
che gilt für seine Interaktionspartner, die sich ihrerseits in ihrem eigenen polychronen Umfeld bewegen. Verfügt der virtuelle Auslandsentsandte also nicht (z.B. durch frühere Auslandsaufenthalte oder interkulturelle Trainingsmaßnahmen) bereits über ein Bewusstsein über seine eigene Zeitorientierung und die seiner Interaktionspartner, bedeutet dies ein großes Potential für interkulturelle Probleme und Missverständnisse.

\subsubsection{Zeithorizont}

Neben der unterschiedlichen Auslegung von Terminen und Deadlines können auch verschiedene Zeit- und Planungshorizonte zu Problemen bei virtuellen Auslandsentsendungen führen. Das von Bluedorn und Standifer als „,temporal depth“ betitelte Konzept der Zeithorizonte beschreibt, „how far into the future and the past people think about things“" (2006, S. 201). Im Kontext virtueller Auslandsentsendungen ist vor allem der in die Zukunft gerichtete Zeithorizont von Bedeutung, da er einen unmittelbaren Einfluss auf Entscheidungen über die Planung von Zielen und Maßnahmen hat. So stellen Bluedorn und Standifer (2006, S. 201) beispielsweise fest, dass die Investitionen von Organisationen umso höher sind, je größer ihre zeitliche Tiefe bzw. je weiter ihr Zeithorizont ist. Diese Beobachtung unterstützt die Vermutung, dass der Zeithorizont einer Person oder Gruppe von Personen ihren Planungshorizont bestimmt oder zumindest entscheidend beeinflusst.

Das 5-Dimensionen-Modell von Hofstede bietet eine Möglichkeit, den Planungshorizont in verschiedenen Kulturen genauer zu untersuchen. So unterscheidet er Kulturen unter anderem danach, ob in ihnen eine langfristige oder eine kurzfristige Zeitorientierung vorherrscht. Aufschluss über den Planungshorizont einer Kultur gibt dabei vor allem, wie schnell von ihren Angehörigen Ergebnisse erwartet werden. Als Kennzeichen einer kurzfristig orientierten Kultur nennt Hofstede (1997, S. 173) die Erwartung von „,quick results“ und stellt dies einer „,perseverance towards slow results" in langfristig orientierten Kulturen gegenüber.

Für einen virtuellen Auslandsentsandten aus einer relativ kurzfristig orientierten Kultur wie Deutschland können bei der Entsendung in eine langfristig orientierte Kultur Konflikte bei der Planung von Zielen und Maßnahmen entstehen. Er wird möglicherweise nicht bereit sein, auf kurzfristige Erfolge oder Gewinne zu verzichten, während seine Interaktionspartner einen solchen Verzicht als notwendig für die Erreichung langfristiger Ziele ansehen. Im Vergleich zu traditionellen Entsandten wird dieses Problem dadurch verschärft, dass sich virtuelle Entsandte in Deutschland physisch in einem Umfeld aufhalten, das durch einen kurzfristigen Zeithorizont geprägt ist. Eine gemeinsame Zukunftsplanung wird dadurch erschwert und im schlimmsten Falle sogar unmöglich. Dies kann zu Unzufriedenheit und Frustration auf beiden Seiten führen, was wiederum die Zusammenarbeit erschweren und somit eine erhebliche Beeinträchtigung für den Erfolg der virtuellen Auslandsentsendung darstellen kann. 


\subsubsection{Vertrauen}

Ein weiteres häufig genanntes Problem ist der Aufbau und die Aufrechterhaltung von Vertrauen zwischen dem virtuellen Auslandsentsandten und seinen Interaktionspartnern. Virtuelle Entsandte haben nur in einem sehr geringem Ausmaß die Möglichkeit, durch unmittelbaren persönlichen Kontakt enge persönliche Beziehungen zu ihren Interaktionspartnern aufzubauen (vgl. Holtbrügge \& Schillo, 2006, S. 322). Die Gründe hierfür sind zum einen die geographische Trennung und zum anderen die unterschiedlichen kulturellen Hintergründe der Interaktionspartner (vgl. Gibson \& Manuel, 2003, S. 59).

Interaktionspartner, die sich in unmittelbarer geographischer Nähe zueinander befinden, können neben der formellen, aufgabenbezogenen Kommunikation auch auf informellem Weg miteinander kommunizieren und interagieren. Eine solche informelle Kommunikation kann etwa durch kurze Gespräche bzw. „Small Talk“ im Büroflur oder am Kaffeeautomaten stattfinden und hilft den Interaktionspartnern, sich auf einer persönlicheren Ebene kennen zu lernen. Dadurch können sie sich ein Bild von der Glaubwürdigkeit und Vertrauenswürdigkeit ihres Gegenübers machen, was die Bildung von gegenseitigem Vertrauen erheblich erleichtert (vgl. Lawley, 2006, S. 13). Virtuellen Auslandsentsandten fehlt diese Möglichkeit der informellen Kommunikation weitestgehend, d.h. ihre Möglichkeiten zur Vertrauensbildung sind stark eingeschränkt.

Auch kulturelle Unterschiede zwischen den Interaktionspartnern haben Einfluss auf die Bildung und Aufrechterhaltung von Vertrauen. Ein wichtiger Einflussfaktor ist dabei die von diesen wahrgenommene Ähnlichkeit zueinander: „Being like each other raises the degree of trust“" (Lawley, 2006, S. 14). Eine geringe wahrgenommene Ähnlichkeit (z.B. aufgrund unterschiedlicher kultureller Hintergründe) kann sich dagegen negativ auf den Grad an gegenseitigem Vertrauen auswirken. Ursächlich hierfür ist, dass der kulturelle Hintergrund einer Person einen wichtigen Einflussfaktor auf das Zugehörigkeitsgefühl dieser Person zu einer bestimmten Gruppe darstellt. Hat nun der Interaktionspartner dieser Person einen anderen kulturellen Hintergrund, so stellt er für diesen einen Zugehörigen einer anderen Gruppe als der eigenen dar. Problematisch dabei ist, dass zwischen Angehörigen verschiedener Gruppen oftmals Misstrauen allein aufgrund der Zugehörigkeit zu diesen Gruppen besteht (vgl. Gibson \& Manuel, 2003, S. 62).

Der kulturelle Hintergrund der Interaktionspartner spielt auch dahingehend eine große Rolle, wie wichtig gegenseitiges Vertrauen in der Interaktion des virtuellen Auslandsentsandten mit seinen Interaktionspartnern ist. So weisen Holtbrügge und Schillo (2006, S. 324) darauf hin, dass eine „langfristige Herausbildung von Vertrauen“ besonders in High-Context-Kulturen von Bedeutung für den Erfolg der Auslandsentsendung ist. Es ist also zu erwarten, dass das Potenzial für Probleme aufgrund der mangelnden Möglichkeit zum Aufbau und zur Aufrechterhaltung von gegenseitigem Vertrauen umso größer ist, je höher die Kontextorientierung in der Zielkultur der virtuellen Entsendung ist. 


\subsubsection{Führung auf Distanz}

Eines der zentralen Merkmale von virtuellen Auslandsentsandten ist deren Weisungsrecht gegenüber ihren Mitarbeitern im Ausland. Dadurch ergibt sich als weiterer Problembereich die als „distance leadership“ (Holtbrügge \& Schillo, 2006, S. 324) bzw. „virtual leadership“ (Lawley, 2006, S. 13) bezeichnete Führung von geographisch entfernten Mitarbeitern, die sich z.B. in den Bereichen des Mentoring, der Kontrolle sowie der Förderung von Mitarbeitern niederschlägt.

\subsubsection{Soziale Präsenz}

Eine wichtige Voraussetzung für die Effektivität der Führung von Mitarbeitern ist, dass die Führung von diesen auch wahrgenommen und erlebt wird. In einem traditionellen Umfeld, also bei unmittelbarer geographischer Nähe zwischen der Führungskraft und den ihr unterstellten Mitarbeitern, hat eine Führungskraft zahlreiche Möglichkeiten, ihre Präsenz als solche zu verdeutlichen und den Mitarbeitern in Erinnerung zu rufen. Schon die Sitzordnung in einer Besprechung, eine geschlossene Bürotür oder andere implizite soziale Botschaften können den Mitarbeitern das Verhältnis zwischen ihnen und der Führungskraft vermitteln (vgl. Zigurs, 2002, S. 344). Ein virtueller Auslandsentsandter kann auf solche Möglichkeiten nur in sehr geringem Ausmaß zurückgreifen. Er ist bei der Schaffung von Präsenz gegenüber seinen Mitarbeitern auf die Nutzung elektronischer Kommunikationsmedien angewiesen. Zigurs (2002, S. 344) bezeichnet eine solche medial erzeugte Präsenz als „telepresence“. Ähnlich wie bei der Effektivität medial vermittelter Kommunikation ist die Erzeugung einer solchen Telepräsenz jedoch von dem Ausmaß an Richness der verwendeten Kommunikationsmedien abhängig (vgl. Zigurs, 2002, S. 342 ff.). Vor dem Hintergrund der oben aufgezeigten relativ geringen Verbreitung von Kommunikationsmedien mit einer hohen Media Richness sind die Möglichkeiten sozialer Präsenz bei virtuellen Auslandsentsendungen damit stark eingeschränkt (vgl. Iten, 2000, S. 116 f.).

\subsubsection{Kontrolle von Mitarbeitern}

Ein weiterer Faktor, der die Führung von Mitarbeitern auf Distanz durch einen virtuellen Auslandsentsandten erschwert, ist die mangelnde Möglichkeit zur Überwachung und Kontrolle der ihm unterstellten Mitarbeiter. So zeigen Hertel et al. im Zusammenhang mit virtuellen Teams, dass ,all kinds of direct control are difficult when team managers are not at the same location as the team members" (2005, S. 80).

Möglichkeiten, diese Schwierigkeiten zu überwinden, werden von Hertel et al. (2005, S. 80 f.) aufgezeigt. Eine Möglichkeit ist die Einführung von „Electronic Performance Monitoring“Systemen. Diese ermöglichen die Erfassung von Arbeitsdaten der Mitarbeiter wie beispielsweise Log-in-Zeiten oder Tastenanschläge sowie die Überwachung von Telefongesprächen oder des E-Mail-Verkehrs hinsichtlich der Art und Qualität der geführten Gespräche. Der praktische 
Nutzen solcher Systeme ist jedoch gering, da bei einer solchen Form der Überwachung eher negative Auswirkungen auf die Arbeitszufriedenheit und den wahrgenommenen Stress der Mitarbeiter zu erwarten sind, als dass sie zu einer Leistungssteigerung beitragen würden.

Eine andere Möglichkeit, den Schwierigkeiten der Führung und Kontrolle von geographisch entfernten Mitarbeitern zu begegnen, ist die verstärkte Übertragung von Verantwortung und Entscheidungsspielräumen an die Mitarbeiter. Ein Beispiel für ein solches delegatives Führungskonzept ist das „Management by Objectives“. Dieser Ansatz basiert auf der Vereinbarung von Zielen, die vom Mitarbeiter zu realisieren sind. Die Bewertung bzw. Kontrolle erfolgt dabei allein anhand der Realisierung dieser Ziele, d.h. das Vorgehen ist weitestgehend dem Mitarbeiter selbst überlassen (vgl. Holtbrügge, 2005, S. 175). Hinsichtlich der Eignung der beschriebenen Formen der Führung von geographisch entfernten Mitarbeitern halten Hertel et al. (2005, S. 81) fest: „While direct leadership strategies are possible in conventional teams, members of virtual teams might be managed more effectively by empowerment and by delegating managerial functions to the members.“

\subsubsection{Motivation von Mitarbeitern}

Entscheidend für den Erfolg einer virtuellen Auslandsentsendung ist auch die Fähigkeit des Entsandten, in seiner Rolle als Führungskraft seine geographisch entfernten Mitarbeiter zu motivieren. Diese Fähigkeit wird entscheidend vom Führungsverhalten der Führungskraft bzw. dem Einsatz von Führungsinstrumenten beeinflusst. Aufgrund dieses engen Zusammenhangs zwischen Führung und Motivation wirken sich die oben beschriebenen Probleme der Effektivität des Führungsstils in unterschiedlichen Kulturen auch unmittelbar auf die Möglichkeit zur Motivation der Mitarbeiter aus. So wird sich beispielsweise ein delegativer Führungsstil in einer Kultur mit hoher Machtdistanz vermutlich negativ auf die Motivation der Mitarbeiter auswirken, während er in einer Kultur mit geringer Machtdistanz eher positiv zu deren Motivation beitragen wird. Auch die geographische Entfernung der Mitarbeiter stellt eine Beeinträchtigung der Möglichkeit zur Motivation von Mitarbeitern dar. Hertel et al. (2005, S. 84) fassen die Gründe hierfür zusammen: „Physical disconnectedness (...) can lead to various challenges of members' work motivation due to any of the following reasons: It is more difficult to implement common goals, feelings of anonymity and low social control may lead to social loafing, self-efficacy is more difficult to maintain due to reduced feedback, and trust is more difficult to build."

\subsubsection{Mentoring von Mitarbeitern}

Ein letztes von den Befragten genanntes Problem der Führung auf Distanz ist das Mentoring von geographisch entfernten Mitarbeitern. Harvey und Wiese (1998, S. 34) definieren Mentoring als „one-to-one relationship between a mentor with advanced experience and knowledge and a protégé with less experience and knowledge." Die Beziehung eines Mentors und seines Protégés sollte sich dabei über viele Jahre hinweg erstrecken und in idealer Weise eine gleichgestellte, mögli- 
cherweise auch freundschaftliche Beziehung zum Ergebnis haben (vgl. Harvey \& Wiese, 1998, S. 35). Mathews (2006, S. 162 ff.) sieht im Mentoring von Mitarbeitern eine wichtige Methode der Personalentwicklung und zeigt eine Vielzahl von Vorteilen auf, die es für die Organisation, den Mentor und den Protégé haben kann. Auf der Organisationsebene können durch Mentoring von Mitarbeitern beispielsweise eine bessere Einschätzung und Beurteilung individueller Leistungen erreicht und neue, viel versprechende Talente besser entdeckt und gefördert werden. Dem Mentor wird unter anderem die Möglichkeit gegeben, seine Führungs- und Kommunikationsfähigkeiten auszubauen, während der Protégé wiederum vom Wissen, den Fähigkeiten und den Netzwerken seines Mentors profitiert.

Im Kontext einer virtuellen Auslandsentsendung sind diese Vorteile jedoch nur in begrenzter Form realisierbar, da auch das Mentoring von Mitarbeitern den Einschränkungen der besonderen Situation unterworfen ist. Dazu zählt insbesondere die geographische Distanz zwischen dem Mentor und dem Protégé. Als eine Möglichkeit, diese Schwierigkeiten zu überwinden schlägt Knouse (2001, S. 163) die Einführung eines Virtual Mentoring oder Telementoring vor, also die Durchführung der gewöhnlichen Mentoring-Tätigkeiten über elektronische Medien. Er zeigt jedoch auch die Einschränkungen solcher alternativen Ausgestaltungsmöglichkeiten auf: „However, building and refining interpersonal skills requires one-on-one contact between mentor and protégé. There must be direct observation of the protégé at work or with other colleagues“" (S. 166).

\subsection{Zusammenfassung und Implikationen}

Virtuelle Auslandsentsendungen stellen eine neue und innovative Form des Personaleinsatzes dar, die gegenüber traditionellen Formen der Stellenbesetzung im Ausland zahlreiche Vorteile besitzen. Diesen stehen jedoch auch viele Probleme gegenüber, die in diesem Beitrag erstmals systematisch untersucht wurden.

Die Befragung von 59 aktuellen oder ehemaligen virtuellen Entsandten zeigt, dass insbesondere die spezifischen Aspekte der interkulturellen und medial vermittelten Kommunikation große Herausforderungen darstellen. Die größte Schwierigkeit besteht darin, dass virtuelle Auslandsentsendungen nur den Einsatz von Kommunikationsmedien mit einer relativ geringen Media Richness ermöglichen. Nuancen der non-verbalen, extra-verbalen und para-verbalen Kommunikation lassen sich deshalb schwer vermitteln, was die Gefahr von Missverständnissen erhöht.

Einen zweiten Problembereich bilden Unterschiede im Zeitverständnis, die sich sowohl auf die wahrgenommene Verbindlichkeit von Terminen und Deadlines als auch auf den Zeithorizont der Entscheidungen auswirken können. Die besondere Problematik für virtuelle Entsandte besteht darin, dass sich diese in ihrem gewohnten Arbeits- und Lebensumfeld bewegen und deshalb keine Anhaltspunkte haben, sich über die Kulturgebundenheit ihrer eigenen Zeitori- 
entierung bewusst zu werden. Die Folge davon können weit reichende interkulturelle Managementprobleme sein.

Ein ebenfalls häufig genanntes Problem ist der erschwerte Aufbau von Vertrauen zwischen dem virtuellen Entsandten und seinen Interaktionspartnern im Gastland. Die fehlende Faceto-Face-Kommunikation erschwert informelle Gespräche und das persönliche Kennenlernen. Besonders relevant ist dieses Problem in Kulturen wie China oder Russland, in denen Berufsund Privatleben in einem geringeren Maße differenziert sind, als dies in Deutschland der Fall ist (vgl. Holtbrügge \& Puck, 2005, S. 22 ff.).

Schließlich stellt die Führung auf Distanz eine große Herausforderung virtueller Auslandsentsendungen dar. Da die Präsenz der im Heimatland tätigen Führungskraft nur medial vermittelt werden kann, stehen virtuellen Entsandten nur wenige Instrumente der Personalführung zur Verfügung. Insbesondere die Möglichkeiten der symbolischen Führung sind stark eingeschränkt. Das Mentoring sowie die Kontrolle und Motivation von Mitarbeitern werden dadurch erheblich erschwert.

Der Nutzen der vorliegenden Untersuchung für die Unternehmungspraxis besteht insbesondere darin, die Problemfelder virtueller Auslandsentsendungen analysiert und deren Relevanz empirisch untersucht zu haben. Unternehmungen, die virtuelle Entsandte einsetzen wollen, erhalten dadurch Ansatzpunkte, welche Herausforderungen damit verbunden sind, und können gezielte Maßnahmen ergreifen, um diese zu bewältigen. Dazu zählen z.B. Kommunikationsschulungen und interkulturelle Trainings. Aus den dargestellten Problemfeldern können zudem Anforderungskriterien für die Auswahl virtueller Auslandsentsandter abgeleitet werden.

Eine Implikation für die zukünftige Forschung besteht insbesondere darin, die herausgearbeiteten Problemfelder für unterschiedliche Anwendungsbereiche, Branchen und Unternehmungstypen zu spezifizieren. So kann etwa vermutet werden, dass die skizzierten Probleme bei kreativen Aufgaben größer als bei Routinetätigkeiten sind. Auch ein starker Einfluss der kulturellen Distanz zwischen Heimat- und Gastland kann vermutet werden.

Ein weiteres Forschungsfeld besteht darin zu untersuchen, wie die skizzierten Herausforderungen durch zielgerichtete Vorbereitungsmaßnahmen und den Einsatz geeigneter Managementinstrumente bewältigt werden können. So kann z.B. angenommen werden, dass sich ein an den spezifischen Anforderungen virtueller Auslandsentsendungen orientiertes interkulturelles Training positiv auf deren Effizienz auswirkt (vgl. Holtbrügge \& Schillo, 2008). Darüber hinaus gilt es, weitere Instrumente und Maßnahmen zu erforschen, die der Bewältigung der Problemfelder virtueller Auslandsentsendungen dienen. 


\section{Literaturverzeichnis}

Adler, N. (2003): Communicating across cultural barriers, in: Bolten, J. \& Erhardt, C. (Hrsg.): Interkulturelle Kommunikation. Texte und Übungen zum interkulturellen Handeln, Sternenfels: Wissenschaft \& Praxis, S. 247-273.

Beamer, L. (1992): Learning Intercultural Communication Competence, in: Journal of Business Communication, 29. Jg., 3, S. 285-303.

Blom, H. \& Meier, H. (2002): Interkulturelles Management. Interkulturelle Kommunikation, Internationales Personalmanagement, Diversity-Ansätze im Unternehmen, Herne/Berlin: NWB.

Bluedorn, A.C. \& Denhardt, R.B. (1988): Time and organizations, in: Journal of Management, 14. Jg., 2, S. 299-320.

Bluedorn, A.C., Felker Kaufman, C. \& Lane, P.M. (1992): How many things do you like to do at once? An introduction to monochronic and polychronic time, in: Academy of Management Executive, 6. Jg., 4, S. 17-26.

Bluedorn, A.C. \& Standifer, R.L. (2006): Time and the temporal imagination, in: Academy of Management Learning \& Education, 5. Jg., 2, S. 196-206.

Friedman, R.A. \& Currall, S.C. (2003): Conflict escalation: Dispute exacerbating elements of e-mail communication, in: Human Relations, 56. Jg., 11, S. 1325-1347.

Gibson, C.B. \& Manuel, J.A. (2003): Building trust. Effective multicultural communication processes in virtual teams, in: Gibson, C.B. \& Cohen, S.G. (Hrsg.): Virtual teams that work. Creating conditions for virtual team effectiveness, San Francisco: Jossey-Bass, S. 59-86.

Hall, E.T. (1981): Beyond culture, New York: Anchor Books.

Harvey, M. \& Wiese, D. (1998): Global Dual-Career Couple Mentoring: A Phase Model Approach, in: Human Resource Planning, 21. Jg., 2, S. 33-48.

Hertel, G., Geister, S. \& Konradt, U. (2005): Managing virtual teams. A review of current empirical research, in: Human Resource Management Review, 15. Jg., 1, S. 69-95.

Hofstede, G. (1997): Cultures and organizations. Software of the mind, New York et al.: McGraw-Hill.

Holtbrügge, D. (2005): Personalmanagement, 2. Aufl. Berlin et al.: Springer.

Holtbrügge, D. \& Puck, J.F. (2005): Geschäftserfolg in China. Strategien für den größten Markt der Welt, Berlin et al.: Springer.

Holtbrügge, D. \& Schillo, K. (2006): Virtuelle Auslandsentsendungen, in: Wirtschaftswissenschaftliches Studium (WiSt), 35. Jg., 6, S. 320-324.

Holtbrügge, D. \& Schillo, K. (2007): Virtuelle Auslandsentsendungen. Konzeptionelle Grundlagen, Anwendungsbeispiele und Bewertung, in: Holtbrügge, D., Holzmüller, H.H. \& Wangenheim, F. v. (Hrsg.): Remote Services. Neue Formen der Internationalisierung von Dienstleistungen, Wiesbaden: Deutscher Universitäts-Verlag, S. 27-36.

Holtbrügge, D. \& Schillo, K. (2008): Intercultural Training Requirements for Virtual Assignments: Results of an Explorative Empirical Study, in: Human Resource Development International, Vol. 11, 3, p. 271-286.

IBM Business Consulting Services (2005): The mobile working experience. A European perspective, http://www-935.ibm.com/services/de/bcs/pdf/2005/mobile-working-experience. pdf, 15.06.2006.

Iten, P.A. (2000): Virtuelle Auslandseinsätze von Personal in multinationalen Unternehmen aus der Sicht aktueller Erkenntnisse des Wissensmanagements, Bamberg.

Iten, P.A. (2001): Virtuelle Auslandseinsätze von Mitarbeitern. Merkmale und Anforderungen einer neuen Entsendungsform, in: zfo, 70. Jg., 3, S. 168-174. 
Kayworth, T. \& Leidner, D. (2000): The global virtual manager: a prescription for success, in: European Management Journal, 18. Jg., 2, S. 183-194.

Kikoski, J.F. (1993): Effective communication in the intranational workplace. Models for public sector managers and theorists, in: Public Administration Quarterly, 17. Jg., 1, S. 84-95.

Kittler, M.G., Holtbrügge, D. \& Pan, Y. (2006): Understanding misunderstanding in intra- and intercultural communication. Findings of a Sino-German experiment. Working Paper No. 1/2006, University of Erlangen Nuremberg, Department of International Management, Nürnberg.

Knapp, K. (2003): Interpersonale und interkulturelle Kommunikation, in: Bergemann, N. \& Sourisseaux, A.L. (Hrsg.): Interkulturelles Management, Berlin/Heidelberg: Springer, S. 109-135.

Knouse, S.B. (2001): Virtual mentors: mentoring on the internet, in: Journal of Employment Counseling, 38. Jg., 4, S. 162-170.

Konopaske, R. \& Ivancevich, J.M. (2004): Global management and organizational behavior, New York: McGraw-Hill/Irwin.

Lawley, D. (2006): Creating trust in virtual teams at Orange, KM Review, 9 Jg., 2, S. 12-17.

Mathews, P. (2006): The role of mentoring in promoting organisational competitiveness, in: Competitiveness Review, 16. Jg., 2, S. 158-169.

McKinney, V.R. \& Whiteside, M.M. (2006): Maintaining distributed relationships, in: Communications of the ACM, 49. Jg., 3, S. 82-86.

Mehrabian, A. (1972): Nonverbal communication, New York: Aldine Publishing Company.

Roebuck, D.B., Brock, S.J. \& Moodie, D.R. (2004): Using a simulation to explore the challenges of communicating in a virtual team, in: Business Communication Quarterly, 67. Jg., 3, S. 359-367.

Rosen, B., Furst, S. \& Blackburn, R. (2006): Training for virtual teams: An investigation of current practices and future needs, in: Human Resource Management, 45. Jg., 2, S. 229-247.

Saunders, C., Van Slyke, C. \& Vogel, D.R. (2004): My time or yours? Managing time visions in global virtual teams, in: Academy of Management Executive, 18. Jg., 1, S. 19-31.

Thomas, A. (2003): Interkulturelle Wahrnehmung, Kommunikation und Kooperation, in: Thomas, A., Kinast, E.-U. \& Schroll-Machl, S. (Hrsg.): Handbuch Interkulturelle Kommunikation und Kooperation. Band 1: Grundlagen und Praxisfelder, Göttingen: Vandenhoeck \& Ruprecht, S. 94-116.

Thomas, A., Kinast, E.-U. \& Schroll-Machl, S. (1999): Entwicklung interkultureller Handlungskompetenzvon international tätigen Fach- und Führungskräften durch interkulturelle Trainings. In: Götz, K. (Hrsg.): Interkulturelles Lernen / Interkulturelles Training, München/ Meiring: Hampp, S. 97-122.

Warkentin, M. \& Beranek, P.M. (1999): Training to improve virtual team communication, in: Information Systems Journal, 9. Jg., 4, S. 271-289.

Welch, D.E., Worm, V. \& Fenwick, M. (2003): Are virtual international assignments feasible?, in: Management International Review, 43. Jg., Special Issue 1, S. 95-114.

XING (2006): Zahlen und Fakten, http://corporate.xing.com/index.php?id=310, 12.11.2006.

Zigurs, I. (2002): Leadership in virtual teams: Oxymoron or opportunity?, in: Organizational Dynamics, 31. Jg., 4, S. 339-351. 



\section{Kapitel 7 \\ Intercultural Training Requirements for Virtual Assignments: Results of an Explorative Empirical Study. ${ }^{1,2}$}

\section{Contents}

7.1 Problem and Objectives

7.2 Virtual Assignments as a New Form of Filling Overseas Positions

7.3 Intercultural Training

7.4 Methodology

7.4.1 Case Study: Virtual Assignments at a Major German Software Company

7.4.1.1 Remote Services as Organizational Context

7.4.1.2 Communication and Service Delivery during the Project

7.4.2 Requirements for Intercultural Training

7.5 Contributions, Limitations and Implications for Future Studies 


\subsection{Problem and Objectives}

One of the main challenges for multinational corporations (MNCs) is to find the right candidates for their overseas positions (e.g., Harvey et al., 2001; Harzing, 2001; Rosenzweig \& Nohria, 1994). Traditionally, MNCs have three alternatives, namely the recruitment of parentcountry, host-country or third-country nationals.

Parent-country nationals (expatriates) are employed for many reasons, such as for the transfer of corporate culture and politics, the facilitation of communication between subsidiaries and headquarters, the broadening of international experience of expatriates and the promotion of loyalty to the headquarters. Using host-country nationals, on the contrary, is often more economical. Moreover, their integration into the subsidiary is easier and they are more likely to be highly motivated. The recruitment of third-country nationals, as the third alternative, gives MNCs access to a larger pool of qualified managers and specialists. It also facilitates the coordination of their various foreign operations.

While these traditional forms of staffing have their particular advantages, there are many disadvantages as well, such as high coordination costs for the headquarters, dual career implications and reintegration problems (e.g., Delios \& Björkman, 2000; Harzing, 2001; Tharenou \& Harvey, 2006). As a result, new alternatives of staffing such as short-term delegations as well as international commuter and frequent flyer assignment are becoming more and more popular in many MNCs (Fenwick, 2004; Harris et al., 2005; PricewaterhouseCoopers, 2000; Welch et al., 2004). The most innovative form is the virtual assignment, which will be the focus of this paper.

Several studies of traditional forms of staffing overseas positions reveal that their success depends largely on a systematic intercultural training (e.g., Blake et al., 1996; Deshpande \& Viswesvaran, 1992; Goldstein \& Smith, 1999). So far, however, no studies regarding the specific training requirements for virtual delegations can be found in the literature. Therefore, it is the objective of this study to analyze the requirements for such intercultural trainings, and to generate propositions for future research. In particular, the requirements for the training of virtual delegates will be analyzed. The study has an explorative character. It is therefore not our aim to present robust answers but rather to describe and analyze the usefulness of intercultural training for virtual assignments and to suggest possible directions for future research.

The paper is organized as follows. In the next section, the main characteristics of virtual assignments as a new form of filling overseas positions will be analyzed. It is followed by a short paragraph on intercultural training. Afterwards, the research design and the methods of the study will be explained. This is followed by a description of remote services as a typical organizational context, in which virtual assignments take place. Based on an explorative study in a major German software company, several propositions on the training requirements for virtual assignments will be derived. The paper ends with a summary of the main results, contributions for managers as well as limitations and some suggestions for future research. 


\subsection{Virtual Assignments as a New Form of Filling Overseas Positions}

An international assignment is called virtual when "an employee does not relocate to a host location, but has international responsibilities for a part of the organization in another country which they manage from the home country" (PricewaterhouseCoopers, 2000, p. 31). According to this definition, virtual assignees remain most of the time in their home country. In comparison with expatriates, virtual assignees are not delegated abroad. They work in the headquarters and use modern electronic media such as e-mails, conference calls or video conferences to communicate with their foreign colleagues, customers or suppliers. This interaction with individuals with other cultural backgrounds in other countries encompasses most of their work. As a result, virtual assignments reduce travel and relocation costs, avoid dual-career problems and enhance flexibility (Holtbrügge \& Schillo, 2006).

Like traditional forms of staffing overseas positions, there are different forms of virtual assignments. Long-term virtual expatriates interact with individuals from a foreign culture over a period of at least one year. During this time-span most of the working time is devoted to the virtual cooperation. Most long-term virtual expatriates do not only have technical but also leadership tasks. The virtual assignment is an important period in his or her work life and a major criterion for future job promotion.

For short-term virtual expatriates, the duration of the assignment is reduced. The virtual delegation is only an episode in his or her career and has only limited impact on organizational structures and human resource management. This form is used typically for projects with exactly specified tasks and objectives.

Virtual commuters switch between virtual interactions with individuals in one foreign culture and face-to-face interactions with individuals at home. The virtual assignment includes less than $50 \%$ of the total working time. Virtual frequent flyers switch between interactions with individuals in several foreign cultures. This form may include for example the simultaneous cooperation with partners in Asia, Europe and the US. Virtual frequent flyers have the highest requirements for intercultural flexibility and competence.

Regardless of their particular form, virtual assignments are characterized by the spatial separation of private and business life. The virtual delegate lives and interacts in one culture, yet he or she works together mainly with people from another culture. While the virtual assignee is physically located in the headquarters, from an organizational and operational point of view, he or she belongs to a foreign subsidiary.

Virtual assignments offer many advantages. One advantage is the ability to work abroad without going abroad. Virtual expatriates work internationally without leaving their familiar surrounding. The time of absence is reduced, which improves the work/life balance. Another advantage is that the family does not have to be relocated. This enables children to follow their education and spouses to maintain their own career, which avoids conflicts within the family 
and dual-career problems. Likewise, the reintegration of virtual expatriates is much easier. Virtual assignees never lose contact to the headquarters and their local colleagues, because they remain integrated into its decision-making processes and networks. Moreover, virtual assignments are often cheaper than traditional forms of expatriation. For example, a salary premium as compensation for relocation abroad is not necessary. Finally, training for family members is superfluous, as they remain in the home country.

However, virtual assignments are characterized by several problems as well. Since face-to-face contacts with colleagues, customers or suppliers are reduced to a minimum, no firsthand experiential learning of foreign cultures takes place. Because of the large geographic distance, the virtual assignee and his counterparts communicate mainly through e-mails, conference calls or video conferences, while personal meetings and subsequently face-to-face communication are very limited. For example, it is not possible to meet colleagues and chat with them on the floor or during lunchtime. This enhances the likelihood of misunderstandings and intercultural management problems (e.g., Briscoe \& Schuler, 2004; Dowling \& Welch, 2004). Especially in Asian countries, where it is indispensable to build up trust for good interpersonal and work relationships, this may cause serious difficulties (e.g., Dyer \& Chu, 2000). Moreover, the richness of electronic media is limited, which makes this form of communication less appropriate for the transfer of implicit knowledge (Holtbrügge \& Berg, 2004). In addition, communication through electronic media becomes more complex due to different communication styles and time zones (Jarvenpaa \& Leidner, 1999). While this might be no problem for individuals from low-context cultures, individuals from high-context cultures are expected to feel less comfortable (Hall, 1966). Moreover, virtual assignees have to switch continuously between home- and host-country interactions that may have a negative impact on their work commitment and identification. As a result, the demands on virtual assignees concerning communication and intercultural skills are very high (Holtbrügge \& Schillo, 2008).

One instrument to overcome these problems of virtual assignments might be intercultural training. Given that efficient performance of virtual delegates is most likely to rely substantially on the competence with communication technology and with intercultural communication, the development and maintenance of these skills is crucial for their success. So far, however, no studies regarding the specific training requirements for virtual delegations can be found in the literature. It is therefore the objective of this study to analyze the requirements for such intercultural training, and to generate propositions for future research.

\subsection{Intercultural Training}

As virtual assignments are a new phenomenon that has emerged in many MNCs in the last few years, their impact on the contents and methods of intercultural training have not yet been studied. Therefore, in the following, a general approach of intercultural training is presented, which 
will be used as a starting point for the subsequent adaptation to virtual assignments.

Brislin and Yoshida (1994) define intercultural training as "formal efforts to prepare people for more effective interpersonal relations and for job success when they interact extensively with individuals from cultures other than their own". In the literature, several concepts, methods and instruments of intercultural training can be found (e.g., Cushner \& Brislin, 1997; Fowler \& Blohm, 2004; Fowler \& Mumford, 1995; Seelye, 1996; Landis et al., 2004; Paige, 2004). Most of them can be classified according to the typology of Gudykunst and Hammer (1983). This typology differentiates between two criteria: the process or method (didactic vs. experiential) by which training is delivered and the content (culture-general vs. culture-specific) of the training. Based on these two criteria four categories of intercultural training can be distinguished: didactic/culture-general, didactic/culture-specific, experiential/culture-general and experiential/ culture-specific training (Figure 7-1).

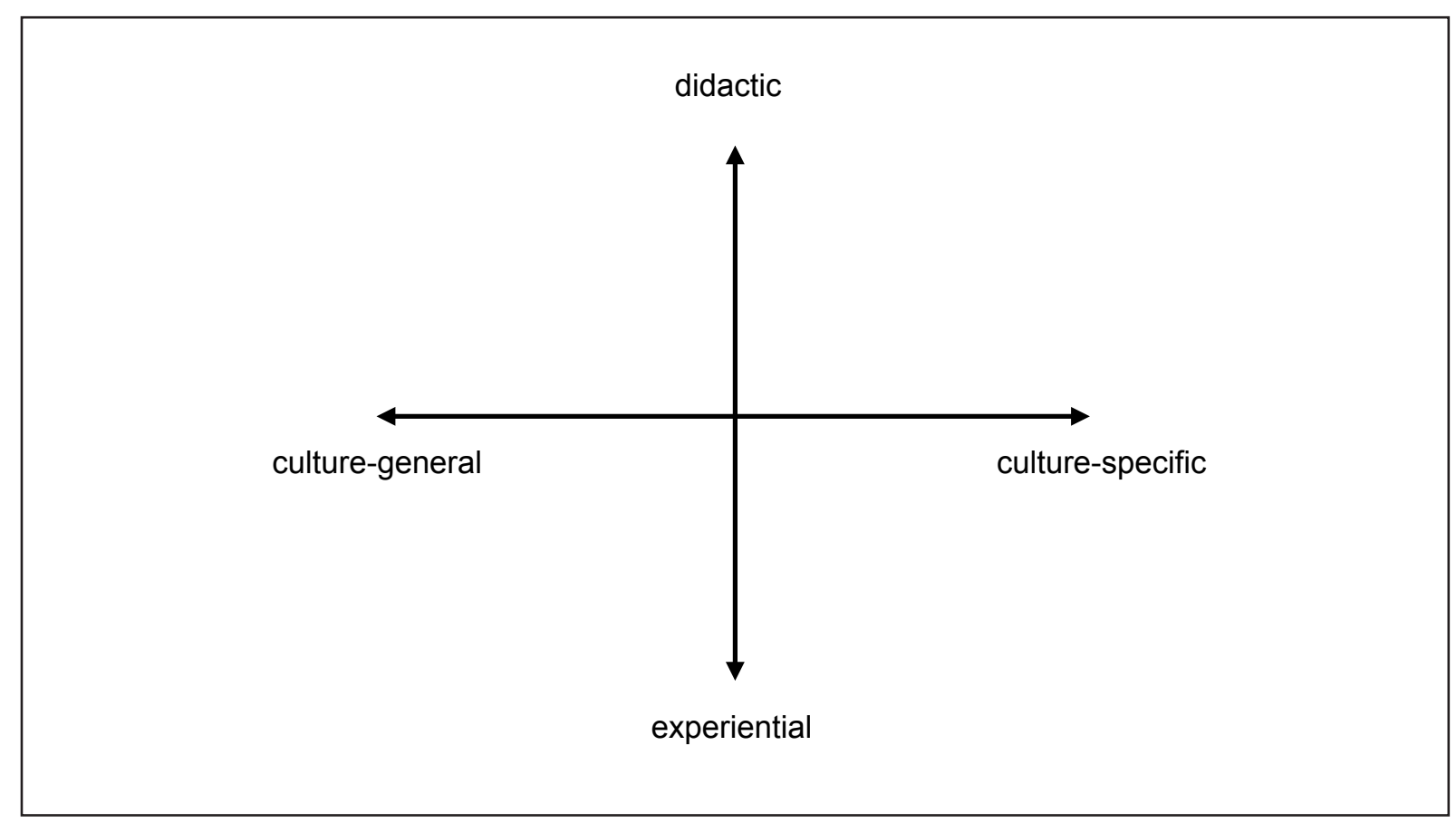

Figure 7-1: $\quad$ Typology of Intercultural Training

Source: $\quad$ Gudykunst \& Hammer, 1983.

Didactic and culture-general training contains general information about culture as well as information about its influence on management practices and interpersonal behavior in particular. Mainly cognitive approaches such as lectures, discussions, films, and culture-general assimilators are used (Gudykunst et al., 1996). Moreover, different concepts of culture such as those developed by Trompenaars (1993), Hofstede (2001) or House et al. (2004) may be explained.

Didactic and culture-specific approaches offer information about a specific culture. For example, country facts and historical backgrounds are imparted with similar methods used in 
didactic and culture-general training. Moreover, language and culture assimilator training may be applied (e.g. Thomas \& Schenk, 2001; Petzold et al., 2005). A culture assimilator is a collection of critical incidents. These are short reports describing situations, in which a problem pertaining to cultural adaptation or cultural differences between interacting parties occurred. Different descriptions are given, from which the trainees have to choose the best explanation considering the situation.

The aim of experiential and culture-general training is to let participants experience situations that might occur in real-life intercultural encounters. For this reason, several simulations and self-assessments such as BaFa BaFa, Barnga or Ecotonos have been developed (Shirts, 1995; Steinwachs, 1995; Hofner Saphiere, 1995). Another culture-general simulation is Explanatorius, which is particularly aimed to assess and to train the communicative competence of the participants (Holtbügge \& Kittler, 2007).

Experiential and culture-specific training such as culture-specific simulations or role plays, contrast-culture training and preliminary trips is aimed to let trainees experience the norms, values and symbols of a specific culture. The main difference to didactic training is that not only cognitive but also emotional and behavioral competencies are imparted.

According to the content, work-related and private life-related training can be distinguished (e.g. Bennett et al., 2000). Work-related training contains information about management aspects which are strongly influenced by culture such as leadership styles, organizational forms or motivation issues. It is aimed at enhancing the performance of managers in cross-cultural business interactions.

Private life-related training takes into consideration that expatriates do not only work, but also live in a foreign country. Often, expatriates are accompanied by their families (Kittler et al., 2006; Konopaske et al., 2005). Therefore, questions regarding accommodation, leisure, potential schools or health care services are raised. The aim of this form of training is to enhance the overall well-being of individuals who live in other countries.

Finally, a distinction can be made according to location between training which takes place in traditional or in virtual classrooms (Garrison \& Anderson, 2003; Rosenberg, 2001). The first alternative is characterized by face-to-face interaction between trainer and trainee. This allows trainers to consider the individual expectations and learning-styles of the participants and to adjust training content and methods accordingly. Typically, a large number of individuals meet at a given time and place.

The major advantage of training in virtual classrooms is their independence of these constraints. Participants may decide independently of others when and where the training takes place. However, the content of computer-based or web-based training has to be preprogrammed, and is therefore highly standardized. 
Although intercultural training is a main topic in the intercultural management literature, its use and impact is largely unclear. In a meta-analysis of 28 studies of the effectiveness of intercultural training, which were published between 1988 and 2000, Mendenhall et al. (2004) found that lectures, presentations, culture assimilators, and class discussions were the methods most often used for intercultural training. Given the predominantly didactic nature of these methods, most intercultural training is effective in enhancing knowledge and trainee satisfaction, but less effective in changing behavior and attitudes and in improving adjustment and performance. However, the authors found a great number of non-significant findings, which indicates the need to investigate potential moderators of training effectiveness. One moderator might be the form of assignment, that is, whether the training is designed for real or virtual delegations.

\subsection{Methodology}

In order to get a deeper insight into the characteristics of virtual assignments and the particular requirements for intercultural training, a case study of a major German software company was conducted. The company was selected for our study because of its extensive experience with virtual assignments during the last few years. The sample consists of virtual assignees who have their office in Germany and who interact mainly with individuals in Asia (particularly in China, India, and Japan) as well as their counterparts in Japan.

Based on an explorative approach, nine semi-structured interviews with former and actual virtual assignees (computer specialists, team leaders and project managers), two Japanese employees and four members of the Japanese customer's project-team were conducted (in the following marked with interview A-N). The respondents located in Germany come from four different cultures and have experiences with all forms of virtual delegations of at least three years. They have experiences with traditional delegations as well. The interviews with the virtual assignees lasted between one and one-and a-half hours and were conducted in the German language. The interviews in Japan lasted between one and three hours and were conducted in English.

In the beginning, the respondents were asked about the general aspects of their virtual assignment such as form, duration and intercultural management problems. Afterwards, the specific aspects of intercultural training were discussed. The respondents were presented with the typology of intercultural training that was developed in the previous section. Then they were asked to evaluate the efficiency of different training methods (didactic vs. experiential), contents (workrelated vs. private life-related) and locations (traditional vs. virtual classroom) for virtual assignments. These alternatives were explained and presented in a neutral manner to reduce the danger of leading respondents to answer questions consistent with prior expectations. Moreover, further measures to reduce possible interviewer bias and to ensure the explorative character of the study were applied. Particularly, the interviewers asked the interviewees to describe their views in their own words and made every effort to "move the interview forward as much as 
possible by building on what the participant has begun to share" (Seidman, 2006, p. 66).

Personal interviews were chosen for their particular advantages with regards to the study of virtual assignments. First, potential misunderstandings can be more easily recognized and rectified. Given the novelty of the topic, this advantage proved to be very important. In personal interviews, unexpected answers can be discussed and further study of particular aspects can be pursued. Additionally, the researcher gains insight into the conditions under which the respondents work which helps him/her to validate the interpretation of soft factors such as emotions, motivations and learning processes (e.g. Denzin \& Lincoln, 2000; Flick, 2006; Lamneck, 2005). Especially in Japan "getting to know each other"and the development of personal relationships are important requirements for successful communication. As one Japanese interviewee mentioned: "You would have got only $20 \%$ of the information, if we did this by telephone or video conference" (Interview NQ4).

All interviews were conducted in the presence of both authors. This allowed for a subsequent discussion and critical reflection of the respondents"statements from various perspectives. Moreover, the danger of misunderstandings and misinterpreting subjective perceptions is reduced, thus, encouraging the communicative validation of the findings. The interviews have been audio-taped, transliterated and computer-analysed by using the software program NVivo (Gibbs, 2002). In the following, all quotations from these interviews are marked with Q1-Qn.

\subsubsection{Case Study: Virtual Assignments at a Major German Software Company}

\subsubsection{Remote Services as Organizational Context}

Virtual assignments are most relevant for companies which are involved in remote services. In contrast to traditional services, remote services are not produced in the physical presence of the customer. With the help of modern information and communication technologies it is possible to provide formerly local services over long distances as well as to incite new forms of services. No direct contact between service providers and their customers is needed. Many examples of remote services have already become part of our daily lives such as online IT-support or remote maintenance of technical equipment. In a more complex way, remote services are used in robotics or in medical technology. For example, in 2001, the first transatlantic surgery took place, when three surgeons in the US operated on a patient in France (Schumann et al., 2006).

A typical example of remote services is the IT-support at a major German software company. The company is the world's third-largest software provider and delivers business solutions around the world to more than 33,200 customers in 120 countries. The company employs 36,600 people in more than 50 countries. The headquarters is located in Germany, with subsidiaries, representation offices, and research centres in 50 countries (company information). 
The department "System Landscape Optimization" (SLO), which stands in the focus of this case study, employs 80 highly qualified IT-experts who support a large number of customers all over the world. One of these customers is a large Japanese retailer, for whom a new software release was installed in 2004 (company information). The various departments of the company had their own IT systems with different versions and customized solutions of the standard software. These scratched systems caused many problems, for example, difficult access to information, hindrances in carrying out analyses concerning the entire company and the presence of a large amount of hardware that used to be serviced. The goal of the project was to build up one new system where all information of the company is merged ("consolidation and migration in one step").

The project followed a typical sequence of steps. At first, the present situation of the customers system(s) and organizational structure(s) were analyzed. After that, a target system was defined and set up, into which all other existing systems had to be integrated. In a next step, the old systems were prepared for the merger. Afterwards, the preparation of the source system began, i.e. by cleaning up the existing data to avoid duplicate documents. During various test cycles, parts of the source data were transferred onto the new system, followed by the last transfer. Finally, the system was checked in an intensive test before it was opened to the users again.

The whole project, from the first presentation of the concept to its final implementation, lasted one year. During that time, most tasks were managed from Germany where the core-project team was located. This multi-cultural team consisted of three Germans, two Dutchmen, one Spaniard and one Slovak. Further technical support was available in the headquarters as well. These technical specialists joined the team occasionally. A Japanese employee acted as a contact person at the customer's location. "The cooperation between the customer, the System Landscape Optimization group, the subsidiary in Japan, and service department was extremely efficient", says the customer engagement manager of the subsidiary in Japan, Fumihiko Nichita, "and helped the consolidation project to become an overall success" (company information).

\subsubsection{Communication and Service Delivery during the Project}

During the project, the core team was located in Germany most of the time and worked remotely from here. The first contact, before the project started and the customer had chosen our company as a consultant, was face-to-face: "A member of the team presented the running order to the customer in Japan" (Interview AQ2). To analyze the present situation of the customer's systems and organizational structures, the team attained access to all files and applications via the web. At that point, the remote part of the project began. "It took us up to 50 days to analyze all systems. We did this remotely from Germany" (Interview AQ2).

Afterwards, the conclusions were again presented at the customer's site in Japan by two team members. "After the remote analyses, we spent two weeks with the project team in Japan. During that time we had many meetings and further analyses in order to clarify most parts of the 
concept (...). The programming took seven to nine weeks. This was followed by the first simulation" (Interview AQ5). Subsequent to each simulation, a test by the customer was conducted. "We cannot test all functions of the system by ourselves, because we do not know which functions are used by the customer; therefore they have to test it on their own" (ibid.). This test was observed by several members of the project team. "During and after the test, we were on-site to discuss further procedures. We had three of those after-test-meetings in Japan. The first time we spent two weeks in Japan, then only a week each" (ibid.). Between those meetings, the team managed all different phases of the project without being on the spot. The final consolidation and migration of systems was conducted remotely as well.

The project manager described the communication between the project team and the Japanese client as follows: "On the project-management level, we communicated via our Japanese project member. [On the technical level], we had direct contact with the customer. However, [in e-mails to the Japanese technicians] we had 1,000 people at cc. [to inform everybody]" (Interview AQ8). "[Our] projects are a mixture of remote and on-site services, but we could accomplish them in the same way totally remotely (...). [To serve customers remotely] is a regular part of our work" (Interview AQ22).

Moreover, virtual assignments are often seen as more efficient, because "you can take your time over it and think about things in detail (...). It is sometimes even more difficult to be on the spot because you are under observation” (Interview BQ29).

Although remote services are the daily business for the company, they contain several challenges as well. The company gets full access to the customer's systems via the web without being on location. This means that the customer is not able to control and to oversee comprehensively what they are actually doing, how the project is going and which difficulties might occur. The customers described this situation as "black box. [As a consequence,] we required lots of information about the on going process" (Interview MQ7). Given the sensibility of corporate data, a maximum level of trust between the two parties concerned is essential. Because personal contacts and face-to-face meetings are limited, this leads to extremely high requirements for the virtual delegates. Trust can only be built and maintained, if the company is able to anticipate the expectations of their customers and to act accordingly. Since provider and customers come from different cultures, the recognition of cultural differences in values, attitudes and behavior should be considered.

The company discovered that, in order to build trust, communication with the customer is very important. "After the first simulation, the customer was really surprised how far we are in the project. After that, we knew we had to stay more in contact with each other (...). You cannot get the mood out of 5 e-mails. And you do not know what is most important for the customer at the moment" (Interview AQ9). After this experience, weekly "issue-lists and conferencecalls"were introduced (Interview AQ11). Although the technical equipment was available, video conferences were not used since the European project members learned that their Japanese 
counterparts were not accustomed to this media and did not feel very comfortable with it. Particularly, they found it easier to read and write in English than to speak in this language.

Generally, the respondents evaluated their experiences with virtual assignments very positively. In particular, the reduced necessity to travel abroad was mentioned. "Business travels are reduced; you need less time to travel back and forth" (Interview BQ31).

This lack of face-to-face communication, however, may also lead to misunderstandings. Particularly when tacit knowledge has to be transferred and complex problems have to be discussed, electronic media have their limits. "At the customers place, things get fixed more easily; to explain problems on the phone takes longer" (Interview BQ32).

Generally, our study indicates that the potential of intercultural misunderstandings is increasing in virtual assignments, since most of the communication is through electronic media. As one respondent mentioned: "Virtual work is different to on-site work. Especially in Asia, you do not experience the context in which a "yes" was said" (Interview CQ20). Depending on the context, it can also mean "no" or "maybe" (Brahm, 2003).

\subsubsection{Requirements for Intercultural Training}

The interviews revealed that the company offers intercultural training to all of its employees, although there is no specific intercultural training for virtual assignees. Moreover, training attendance is voluntary. "I have heard about [intercultural] training, but have never been to any" (Interview BQ29). Despite this impediment, the respondents unanimously mentioned that intercultural training would have been useful and that several problems that occurred during their virtual assignment could have been prevented. One respondent reports: "You need the same intercultural competencies as real expatriates. You need to know that you are calling a Japanese, you cannot see him or her, so, there is no need to take a bow but you still have to be able to interpret in the right way" (Interview IQ11). "You need to be sensitized for such [intercultural] situations; otherwise you do not know what the other person is trying to tell you" (Interview CQ20). If the virtual delegates had known more about the communication style and the information requirements of their Japanese counterparts beforehand, this time-consuming experience could have been avoided. Generally, our respondents argued that intercultural training could help to overcome the geographical and cultural distance and to enhance the ability of virtual assignees to communicate via electronic media. Thus, the following proposition can be derived:

Proposition 1: Intercultural training has a positive impact on the efficiency of virtual assignments. 
Intercultural training, however, cannot be expected to be efficient per se. Virtual delegations have specific training requirements that differ from traditional foreign assignments. With reference to training content, two differences are particularly important, namely the lack of personal experiences in the foreign country and of face-to-face communication. As pointed out earlier, virtual assignees remain most of the time in their home country. Because of this spatial separation of private and business life, no adjustment to the living conditions in the foreign country is necessary. Only adjustment to work-context is required. For example, virtual delegates do not have to learn how to use chopsticks, to greet people or to dress in a culturally appropriate way. In contrast to traditional expatriates, virtual assignees will not experience hot summers in India, power cuts in China or crowded subways in Japan. One respondent reports, "I haven't thought about an intercultural training as I was not supposed to go there on a business trip" (Interview FQ11). This statement reveals that intercultural training for virtual assignees should not be limited to issues that are important when living in another country. In contrast, they should concentrate on work-related aspects such as different perceptions of deadlines, decision-making processes or attitudes to work in an intercultural context. Indians, for example, view a delay or change of schedule upon short notice as normal. For a German virtual delegate this means a disruption of his or her pre-defined schedule, causing anger and frustration. This could have been prevented if the delegate was aware of these differences and knew why understandings of time are different in other cultures.

With reference to the lack of face-to-face communication, training for virtual assignees should include information about new technologies such as video conferences, chat rooms, blogs or WebEx-Sessions and their compatibility across national and organizational borders. In contrast, knowledge of important elements of face-to-face communication such as mimic and gestures or dress code is less relevant. One respondent mentioned "That is the advantage of working remote: you do not need to look as neat as a pin every day" (Interview HQ15). In addition to learning new technologies, virtual delegates must be able to select the appropriate communication media according to the given task and cultural context they work in ("netiquette') (Rosen et al., 2006). For example, training about different national cultures based on the works of Hofstede, Trompenaars and others might be provided (Duarte \& Snyder, 2001). Particularly useful are information on different communication styles and communication training which takes into account the characteristics of electronic media. This is especially important for virtual delegates with intensive contacts to individuals from Asian cultures. As one respondent mentioned "We did not call our Japanese customers spontaneously. Japanese get embarrassed very easily. Instead of this, we wrote e-mails or called our Japanese team member (...). It is very important that the Japanese do not lose their face" (Interview BQ16).

Thus, the following proposition can be derived: 


\section{Proposition 2a: Intercultural training is more efficient when the training content is adapted to the specific requirements of virtual assignments. Work-relat- ed content is more efficient than private life-related content. Moreover, information about electronic communication technologies and their culture-specific use is more efficient than information about face-to- face communication.}

Our respondents did not indicate any preferences for particular training methods, that is how content will be imparted. However, it can be derived from the interviews that cognitive elements, such as information about work-related aspects of other cultures and the culture-specific use of electronic media, are indispensable. This can be imparted most efficiently by didactic methods such as lectures, presentations or fact sheets. Experiential methods, on the other hand, seem to be less important. In virtual assignments, through which tasks are managed from a distance, communication takes place mainly via electronic media. This offers the opportunity to reflect longer on possible answers and the use of expressions. Acting spontaneously in a culturally adequate way is less important. One respondent described this as follows: "I like virtual work. It gives me the freedom to answer unhurriedly" (Interview CQ12).

Moreover, virtual delegates often do not have much time to prepare for their assignment. Particularly, if the reason for their assignment is working on a temporary project instead of filling a permanent position in a foreign subsidiary, the preparation time is very short. Therefore, an adequate intercultural training must be relatively short and flexible. Two respondents mentioned that a training which uses electronic media such as CDs or DVDs and which could be performed independently of time and location would be preferred. Moreover, internet platforms and chat rooms on intercultural topics might be useful. Generally, it can be proposed:

\section{Proposition 2b: Intercultural training is more efficient when training methods are adapted to the specific requirements of virtual assignments. Didactic training is more efficient than experiential training. Moreover, train- ing in virtual classrooms is more efficient than training in traditional classrooms.}

Intercultural training has the greatest impact when they are offered not only to the virtual assignees, but also to their counterparts in the host country. As mentioned in the previous section, one of the greatest challenges for virtual assignments is to avoid intercultural misunderstandings and to build trust without regular face-to-face contact. According to our interviews, a major source of misunderstandings is due to a lack of intercultural knowledge. For example, for the virtual expatriates, it appeared to be very difficult to understand the expectations of their Japanese counterparts and to learn about their communication style. It can be assumed that the Japanese employees and customers perceived similar communication problems with the 
employees in Germany. If all of them had been trained beforehand, these problems could have been at least partially avoided. One important objective of training is to standardize knowledge of all participants and to develop a common ground for them. Moreover, it enables them to learn about the cultural norms and values of their concrete counterparts. Consequently, intercultural training is particularly efficient when it is attended by all participants of a virtual interaction. As one respondent mentioned: "In advance, both parts should be made sensitive to that" (Interview CQ30). This leads to the following proposition:

\section{Proposition 2c: Intercultural training is more efficient when more participants of the virtual interaction are involved.}

Our interviews show evidence for the assumption that the impact of intercultural training on the efficiency of virtual assignments is moderated by several other variables. One important influence is the cultural distance between the virtual assignees and their counterparts in the host-country. Cultural distance can be defined as the mean difference of the norms, values and attitudes between two cultures (e.g. Kogut \& Singh, 1988; Shenkar, 2001). For example, the respondents found it much easier to work together with Americans than with the Japanese: "Working remote is easy with Americans; they have the same cultural background" (Interview BQ30); "In a project with another customer, we have more problems. The project team consists of many Japanese employees, with a lack of technical knowledge. We [the virtual delegates] have the technical background, but do not know the Japanese culture. Once we told the customer what has to be done (...). Japanese always see the customer at least one hierarchical level above them. They would never talk to the customer in that way" (Interview DQ22).

Theoretically, this finding may be explained by the concept of high- and low-context cultures developed by Hall (1996). According to Hall, communication between the members of two cultures is more successful, the more similar the mind sets of the counterparts are. On the contrary, communication between one individual belonging to a high-context culture and another individual belonging to a low-context-culture may lead to misunderstandings. As a result, intercultural training as a way to overcome communication problems is particularly important when the cultural distance between the virtual delegates and their counterparts in the host-country is large:

Proposition 3a: The impact of intercultural training on the efficiency of virtual assignments is moderated by the cultural distance between the counterparts. Intercultural training is more efficient when the cultural distance is larger.

Another moderator variable between intercultural training and the efficiency of virtual assignments is the international experience of the assignee. All interviewees in our study have long international experiences, so they felt well prepared for their virtual assignment and did not take 
part in any intercultural training beforehand. This finding is in accordance with the literature on traditional assignments, that intercultural training is the more important, the less internationally experienced the trainees are (e.g. Webb, 1996; Bennett et al., 2000). In line with this, one respondent reported of a former colleague who had no previous international experience: "Once he talked to his [Asian] customers about the mistakes they have made very directly. $\mathrm{He}$ did that in a great audience. The next day, nobody wanted to talk to him anymore." Thus, it can be proposed:

\section{Proposition 3b: The impact of intercultural training on the efficiency of virtual as- signments is moderated by the former international experience of the counterparts. The less internationally experienced the virtual assignee is, the more efficient the intercultural training.}

Finally, our study indicates that the impact of intercultural training on the efficiency of virtual assignments is moderated by their particular form. Long-term virtual expatriates, on the one hand, interact with individuals from a foreign culture over a period of at least one year. The virtual assignment is an important period in his or her work life and a major criterion for future job promotion. Therefore, culture-specific training is essential for teaching of the characteristics corresponding to a particular culture. Virtual frequent flyers, as the other extreme case, switch permanently between interactions with individuals from several foreign cultures. Their basic requirement is not the adjustment to one particular culture, but the flexibility to interact simultaneously with members from different cultures. Moreover, the virtual delegation to different host-countries may occur rather spontaneously, so that detailed culture-specific trainings are not feasible. As one respondent remarked: "I worked (...) for the project [with the Japanese customer], but alongside you always work for smaller projects (...). You don't know in which project you will be needed tomorrow" (Interview EQ5). Thus, it can be followed:

\section{Proposition 3c: The impact of intercultural training on the efficiency of virtual as- signments is moderated by the duration of virtual assignments. The lon- ger the virtual assignment lasts, the more efficient are culture-specific elements.}

Summarizing the main results of our case study, there is a strong indication that intercultural training has a positive impact on the efficiency of virtual assignments. However, the adaptation of training contents, methods and participants to the specific requirements of virtual assignments is necessary. Moreover, we found arguments that the impact of intercultural training on the efficiency of virtual assignments is moderated by the cultural distance between the homeand the host-country, the degree of international experience attained by the assignee and the particular form of the assignment. Our propositions regarding the influence of intercultural training on the efficiency of virtual assignments are summarized in Figure 7-2. 


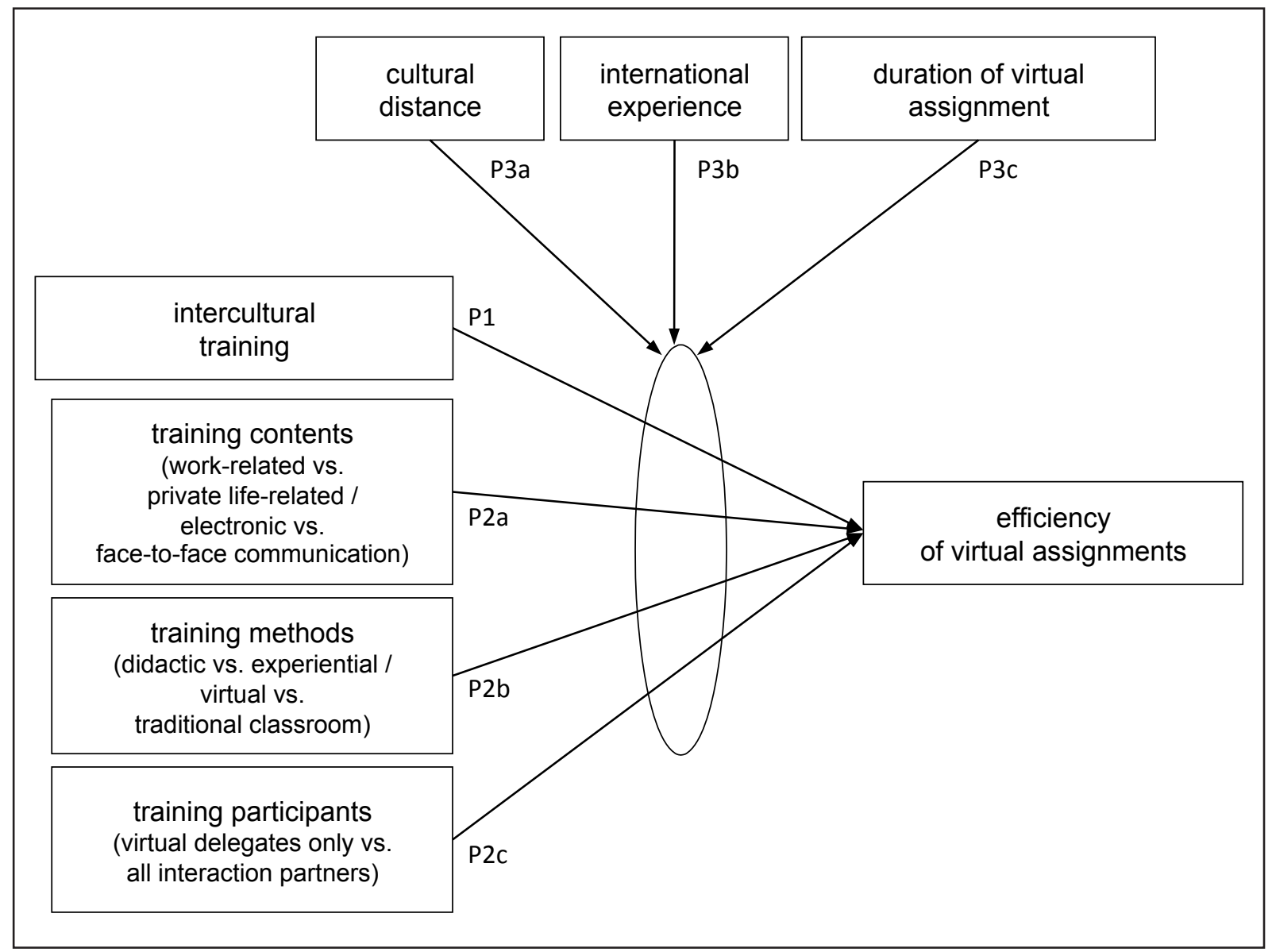

Figure 7-2: $\quad$ Summary of research propositions

\subsection{Contributions, Limitations and Implications for Future Studies}

This study is the first to analyze the requirements for intercultural training within the field of virtual assignments. It suggests that virtual delegations are characterized by several intercultural management problems such as a lack of face-to-face communication, different time zones and communication styles as well as language barriers and the lack of common trust-building mechanisms. Intercultural training is perceived as a useful instrument for overcoming these challenges. It is particularly important because virtual delegates cannot learn through their own observations of and experiences with other cultures. Thus, a mediated form of learning through intercultural training is needed. However, this has to be adapted to the specific requirements of virtual expatriates, e.g., work-related content and information about electronic communication should be provided, most preferably in virtual classrooms that allow virtual delegates to learn independent of time and space. Moreover, intercultural training should not only be offered to the virtual delegates themselves, but also to their team members in the home country as well as to the individuals with whom they interact in the host country. As this study illustrates, even leading companies in the area of virtual and remote work have only taken the first steps in this direction. 
A concrete suggestion for intercultural training that can be derived from this study and which takes into consideration our propositions concerning training content, methods and participants is to improve electronic communication skills in an intercultural context. For example, a group of employees who are involved in a virtual delegation could be asked to write an e-mail about a given topic to all other group members. In this e-mail, a certain degree of urgency (very urgent, neutral, less urgent) and mood (friendly, neutral, unfriendly) should be expressed. The receivers should not know about the particular content of these instructions. Afterwards, they would be asked how they perceived the urgency and the mood of the mail. A comparison between intentions and perceptions could lead to a discussion about different communication styles and could help the participants to formulate e-mails, which are better understood in a different cultural context.

While this study made several contributions to the state of knowledge on virtual assignments in general and on training requirements in particular, it has several limitations as well. First, it is restricted to virtual delegates from Germany who interact with business partners in Asia. It is possible that virtual delegates working with individuals in other countries perceive other training requirements. Second, we analyzed virtual delegations in the context of remote services, only. While within this field virtual delegations are very common, it is unclear whether the results may be transferred to other industries and organizational backgrounds. Even within this industry, differences between the companies focused on in this case study and other firms may be observed. Moreover, this study is based on a small number of respondents who are, however, extremely experienced in the field of virtual delegations.

From a methodological point of view, the explorative approach of this study proved to be very suitable. All interviewed virtual assignees responded very openly and in great detail to our questions. As one respondent mentioned, the interviews allowed them to reflect on their own work and to think about possible changes. In particular, specific training programs for virtual delegates at the company are now under consideration.

Since virtual delegations are expected to continue gaining significance in the future, companies should invest in the analysis of intercultural management issues and intercultural trainings. In the next years, for the company of our case study - as well as for many other companies - virtual delegation is set to become a main topic of human resource management. Hence, further studies should broaden the scope of research and extend its focus to other industries and organizational contexts where virtual assignments are common. Moreover, quantitative studies may enhance the representativeness of this study and analyze the influence of further variables on the country, firm and individual level. For such studies, our research propositions may be seen as a starting point for the refinement and further testing of hypotheses. 


\section{References}

Bennett, R., Aston, A. \& Colquhoun, T. (2000): Cross-cultural Training: A Critical Step in Ensuring the Success of International Assignments, in: Human Resource Management, Vol. $39,2 / 3$, p. 239-250.

Blake, J.M., Heslin, R. \& Curtis, S. (1996): Measuring Impacts of Cross-cultural Training, in: Landis, D. \& Baghat, R. (eds.): Handbook of Intercultural Training, 2nd ed., Thousand Oak: Sage Publications, p. 165-182.

Brahm, L.J. (2003): When Yes Means No! (or Yes or Maybe). How to Negotiate a Deal in China, Boston: Tuttle.

Briscoe, D.R. \& Schuler, R.S. (2004): International Human Resource Management, 2nd ed., New York: Routledge.

Brislin, R.W. \& Yoshida, T. (1994): Intercultural Communication Training. An Introduction, Thousand Oaks: Sage.

Cushner, K. \& Brislin, R.W. (1997): Key Concepts in the Field of Cross-Cultural Training. An Introduction, in: Cushner, K. \& Brislin, R. (eds.): Improving Intercultural Interactions: Modules for Cross-Cultural Training Programs, Vol. 2, Thousand Oaks: Sage, p. 1-17.

Delios, A. \& Björkman, I. (2000): Expatriate Staffing in Foreign Subsidiaries of Japanese Multinational Corporations in the PRC and the United States, in: International Journal of Human Resource Management, Vol 11, 2, p. 278-293.

Denzin, N.K. \& Lincoln, Y.S. (eds.) (2000): Handbook of Qualitative Research, 2nd ed. Thousand Oaks: Sage.

Deshpande, S.P. \& Viswesvaran, C. (1992): Is Cross-cultural Training of Expatriate Managers Effective: A Meta Analysis, in: International Journal of Intercultural Relations, Vol. 16, 3, p. 295-310.

Dowling, P.J. \& Welch, D.E. (2004): International Human Resource Management. Managing People in a Multinational Context, 4th ed, London: Thomson.

Duarte, D.L. \& Snyder, N.T. (2001): Mastering virtual Teams: Strategies, Tolls, and Techniques that succeed, 2nd ed., San Francisco: Jossey-Bass.

Dyer, J.H. \& Chu, W. (2000): The Determinants of Trust in Supplier-automaker Relationships in the US, Japan, and Korea, in: Journal of International Business Studies, Vol. 31, 2, p. 259285.

Fenwick, M. (2004): On International Assignment. Is Expatriation the Only Way to Go?, in: Asia Pacific Journal of Human Resources, Vol. 42, 3, p. 365-377.

Flick, U. (2006): An Introduction to Qualitative Research, 3rd ed, Thousand Oaks: Sage.

Fowler, S.M. \& Blohm, J.M. (2004): An Analysis of Methods for Intercultural Training, in: Landis, D., Bennett, J.M. \& Bennett, M.J. (eds.): Handbook of Intercultural Training, 3rd ed., Thousand Oaks: Sage, p. 37-84.

Fowler, S.M. \& Mumford, M.G. (eds.) (1995): Intercultural Sourcebook: Cross-Cultural Training Method, Vol. 1, Yarmouth, Maine: Intercultural Press.

Garrison, D.R. \& Anderson, T. (2003): E-learning in the 21st Century: A Framework for Research and Practice, London: Routledge.

Gibbs, G.R. (2002): Qualitative Data Analysis: Explorations with NVivo. Buckingham: Open University Press.

Goldstein D.L. \& Smith, D.H. (1999): The Analysis of the Effects of Experiential Training on Sojourners Cross-cultural Adaptability, in: International Journal of Intercultural Relations, Vol. 23, 1, p. 157-173.

Gudykunst, W. \& Hammer, M. (1983): Basic Training Design. Approaches to Intercultural Training, in: Landis, D. \& Brislin, R. (eds.): Handbook of Intercultural Training, Vol. 1, Is- 
sues in Theory and Design, New York: Sage.

Gudykunst, W., Guzley, R.M. \& Hammer, M. (1996): Designing Intercultural Training, in: Landis, D. \& Baghat, R.S. (eds.): Handbook of Intercultural Training, 2nd ed., Thousand Oaks: Sage, p. 61-80.

Hall, E.T. (1966): The Hidden Dimension, New York: Anchor Press/Doubleday.

Harris, H., Brewster, C. \& Erten, C. (2005): Auslandseinsatz, aber wie?, in: Stahl, G.K., Mayrhofer, W. \& Kühlmann, T.M. (eds.): Internationales Personalmanagement, München/ Mering: Hampp, p. 272-291.

Harvey, M., Speier, C. \& Novecevic, M.M. (2001): A Theory-based Framework for Strategic Global Human Resource Staffing Policies and Practices, in: International Journal of Human Resource Management, Vol. 12, 6, p. 898-915.

Harzing, A. (2001): Who's in Charge? An Empirical Study of Executive Staffing Practices in Foreign Subsidiaries, in: Human Resource Management, Vol. 40, 2, p. 139-58.

Hofner Saphiere, D.M. (1995): Ecotonos. A Multicultural Problem-Solving Simulation, in: Fowler, S.M. \& Mumford, M.G. (eds.): Intercultural Sourcebook: Cross-Cultural Training Method, Vol. 1, Yarmouth: Intercultural Press, p. 117-126.

Hofstede, G. (2001): Culture's Consequences. International Differences in Work Related Values, 2nd ed., Thousand Oaks: Sage.

Holtbrügge, D. \& Berg, N. (2004):. Knowledge Management in Multinational Corporations. Results of an Empirical Study among German Firms, in: Management International Review, Vol. 44, Special Issue 3, p. 129-145.

Holtbrügge, D. \& Kittler, M.G. (2007): Understanding Misunderstanding in Intra- and Intercultural Communication, in: Oesterle, M.-J. (ed.): Internationales Management im Umbruch. Globalisierungsbedingte Einwirkungen auf. Theorie und Praxis Internationaler Unternehmensführung, Wiesbaden: Deutscher Universitäts-Verlag, p. 341-370.

Holtbrügge, D. \& Schillo, K. (2006): Virtuelle Auslandsentsendungen, in: Wirtschaftswissenschaftliches Studium, Vol. 35, 6, p. 320-324.

Holtbrügge, D. \& Schillo, K. (2008): Managing from a Distance: Virtual Delegation to India, in: Hendel, A., Messner, W. \& Thun, F. (eds.): Rightshore! Successfully Industrialize SAP® Projects Offshore, Berlin: Springer, p. 121-144.

House, R.J., Hanges, P.J., Javidan, M., Dorfman, P.W. \& Gupta, V. (eds.) (2004): Culture, Leadership, and Organizations. The GLOBE Study of 62 Societies, Thousand Oaks: Sage.

Jarvenpaa, S.L. \& Leidner, D.E. (1999): Communication and Trust in Global Virtual Teams, in: Organization Science, Vol. 10, 6, p. 791-815.

Kittler, M.G., Holtbrügge, D. \& Ungar, M. (2006): Ist die kulturelle Anpassung von Entsandten eine Familienangelegenheit? - Eine empirische Untersuchung deutscher Fach- und Führungskräfte und deren Familien im Ausland, in: Zeitschrift für Personalforschung, Vol. 20, 2, p. 121-140.

Kogut, B. \& Singh, H. (1988): The Effect of National Culture on the Choice of Entry Mode, in: Journal of International Business Studies, Vol. 19, 3, p. 411-432.

Konopaske, R., Robie, C. \& Ivancevich, J.M. (2005): A Preliminary Model of Spouse Influence on Managerial Global Assignment Willingness, in: International Journal of Human Resource Management, Vol. 16, 3, 405-426.

Lamnek, S. (2005): Qualitative Sozialforschung, 4th ed., Weinheim/Basel: Beltz.

Landis, D., Bennett, J.M. \& Bennett, M.J. (eds.) (2004): Handbook of Intercultural Training, 3rd ed, Thousand Oaks: Sage.

Mendenhall, M.E., Stahl, G.K., Ehnert, I., Oddou, G., Osland, J.S. \& Kühlmann, T.M. (eds.) (2004): Evaluation Studies of Cross-Cultural Training Programs. A Review of the Literature from 1988 to 2000, in: Landis, D., Bennett, J.M. \& Bennett, M.J. (eds.): Handbook of Inter- 
cultural Training, 3rd ed., Thousand Oaks: Sage, p. 129-143.

Paige, R.M. (2004): Instrumentation in Intercultural Training, in: Landis, D., Bennett, J.M. \& Bennett, M.J. (eds.): Handbook of Intercultural Training, 3rd ed., Thousand Oaks: Sage, p. $85-125$.

Petzold, I., Ringel, N. \& Thomas, A. (2005): Beruflich in Japan. Trainingsprogramm für Manager, Fach- und Führungskräfte, Göttingen: Vandenhoeck \& Ruprecht.

PricewaterhouseCoopers (2000): Managing a Virtual World. International Non-standard Assignments, Policy and Practice. Europe: Pricewaterhouse Coopers.

Rosen, B., Furst, S. \& Blackburn, R. (2006): Training for Virtual Teams: An Investigation of Current Practices and Future Needs, in: Human Resource Management, Vol. 45, 2, p. 229-247.

Rosenberg, M.J. (2001): E-Learning: Strategies for Delivering Knowledge in the Digital Age, New York: McGraw-Hill.

Rosenzweig, P.M. \& Nohira, N. (1994): Influences in Human Resource Management Practices in Multinational Corporations, in: Journal of International Business Studies, Vol. 25, 2, p. 229-251.

Schumann, J.H., Keller, N.V. \& Wangenheim, F. v. (2006): Technology-Mediated Services: A Typology and Implications for Research and Management. EXFED Working Paper Series No 1.

Seelye, N. (ed.) (1996): Experiential Activities for Intercultural Learning, Yarmouth: Intercultural Press.

Seidman, I. (2006): Interviewing As Qualitative Research: A Guide for Researchers in Education and the Social Sciences, New York: Teachers College Press.

Shenkar, O. (2001): Cultural Distance Revisited: Towards a More Rigorous Conceptualization and Measurement of Cultural Differences, in: Journal of International Business Studies, Vol. 32, 3, p. 519-535.

Shirts, G.R. (1995): Beyond Ethnocentrism: Promoting Cross-Cultural Understanding with BaFa BaFa, in: Fowler, S.M. \& Mumford, M.G. (eds.): Intercultural Sourcebook: CrossCultural Training Method, Vol. 1, Yarmouth: Intercultural Press, p. 93-100.

Steinwachs, B. (1995): A Game for all Seasons, in: Fowler, S.M. \& Mumford, M.G. (eds.): Intercultural Sourcebook: Cross-Cultural Training Method, Vol. 1, Yarmouth: Intercultural Press, p. 101-108.

Tharenou, P. \& Harvey, M. (2006): Examining the Overseas Staffing Options Utilized by Australian Headquartered Multinational Corporations, in: International Journal of Human Resource Management, Vol. 17, 6, p. 1095-1114.

Thomas, A. \& Schenk, E. (2001): Beruflich in China. Trainingsprogramm für Manager, Fachund Führungskräfte, Göttingen: Vandenhoeck \& Ruprecht.

Trompenaars, F. (1993): Riding the Waves of Culture. Understanding Cultural Diversity in Business, London: Nicholas Brealey Publishing.

Webb, A. (1996): The Expatriate Experience: Implications for Career Success, in: Career Development International, Vol. 1, 5, p. 38-44.

Welch, D.E., Worm, M. \& Fenwick, M. (2003): Are Virtual International Assignments Feasible?, in: Management International Review, Vol. 43, Special Issue 1, p. 95-114. 


\section{Kapitel 8 \\ Zusammenfassung und Implikationen}

\section{Gliederung}

8.1 Zusammenfassung der Erkenntnisse

8.2 Implikationen für die Forschung

8.3 Implikationen für die Unternehmungspraxis 


\subsection{Zusammenfassung der Erkenntnisse}

Fasst man die Erkenntnisse der vorliegenden Arbeit zusammen, so zeigen die verschiedenen Analysen, dass die virtuelle Auslandsentsendung bereits in vielen Bereichen Eingang in die Unternehmungspraxis gefunden hat.

In Kapitel zwei wird deutlich, dass mit dem Vorteil der virtuellen Auslandsentsendung, nämlich dem Verbleib des Entsandten am heimatlichen Standort, Nachteile von klassischen Entsendungen überwunden werden. Dazu zählen Kosteneinsparungen, die im Zusammenhang mit realen Entsendungen stehen, Kosten für die Vorbereitung des Entsandten und der Familie, Reisekosten, Zahlungen für Kompensationen, Übersiedlung der Familie, Schulgeld der Kinder sowie Kosten der Reintegration. Weitere entscheidende Vorteile gegenüber der klassischen Auslandsentsendung sind die Verringerung der physischen und psychischen Belastung des Entsandten, Verkürzung der Abwesenheitszeiten sowie die Konstanz im privaten Bereich. Zudem ist der Einsatz virtueller Entsandter ausgesprochen flexibel, bei Bedarf kann der Mitarbeiter am selben Tag bei Kunden in Asien, Europa und Amerika eingesetzt werden.

Der Vorteil des Verbleibs am Heimatort bildet auf der anderen Seite auch den größten Nachteil der virtuellen Auslandsentsendung. Durch die räumliche Trennung sind persönliche Kontakte und damit die Möglichkeiten zur Vertrauensbildung auf ein Minimum reduziert. Eine wichtige Voraussetzungen für das erfolgreiche Arbeiten eines virtuellen Entsandten ist die Beherrschung von elektronischen Informations- und Kommunikationsmedien. Ebenso sollte er Einfühlungsvermögen und kulturelles Verständnis besitzen, um angemessen auf den Interaktionspartner eingehen zu können.

Der Einsatz virtueller Entsendung scheint zwischen low-context-Kulturen (z.B. Deutschland und den Vereinigten Staaten) einfacher zu sein, da hier direkt und explizit kommuniziert wird. Der Einsatz bei Kunden aus high-context-Kulturen (z.B. China oder Japan) erweist sich hingegen als schwieriger, da wichtige Teile der Information implizit durch non-verbale Kommunikation übermittelt werden. Ebenso ist in asiatischen Kulturen der Aufbau von persönlichen Beziehungen und Vertrauen für eine erfolgreiche geschäftliche Zusammenarbeit unerlässlich. Gerade Letzteres ist im virtuellen Kontext sehr schwierig.

Das dritte Kapitel weist zunächst empirisch nach, dass virtuelle Auslandsentsendungen in der Praxis relevant sind und als alternative Besetzungsform zu traditionellen Entsendungen gesehen und in der Unternehmungspraxis eingesetzt werden. Desweiteren zeigen die Ergebnisse der empirischen Studie zum Knowledge-based View, unter welchen Bedingungen virtuelle Entsandte als Instrument zum Wissenstransfer zwischen Mutter- und ausländischer Tochtergesellschaft eingesetzt werden. So werden virtuelle Entsandte häufiger eingesetzt, wenn die Intensität des Wissenstransfers zwischen Mutter- und Tochtergesellschaft hoch ist. Ebenso steigt der Einsatz, je höher das Verhältnis von elektronischer zu persönlicher Kommunikation ist. Allerdings konnte kein Zusammenhang zwischen der Richtung des Wissenstransfers und dem Einsatz von 
virtuellen Entsandten nachgewiesen werden. Die Annahme, dass virtuelle Entsandte den Wissenstransfer von der Tochter- zur Muttergesellschaft vereinfachen, wurde damit nicht bestätigt. In Kapitel vier wird deutlich, dass virtuelle Auslandsentsandte auch als Kontrollinstrument für ausländische Tochtergesellschaften eingesetzt werden. Nur 15\% der befragten Tochtergesellschaften geben an, keine virtuellen Entsandten zu diesem Zweck einzusetzen. Darüber hinaus zeigt die Studie, dass der Einsatz von virtuellen Entsandten als Kontrollinstrument von den Transaktionskosten zwischen Mutter- und Tochtergesellschaft abhängt. Insbesondere wird deutlich, dass mehr virtuelle Entsandte eingesetzt werden, wenn die Faktorspezifität in der Tochtergesellschaft hoch ist. Ebenso steigt der Einsatz mit einer steigenden Transaktionsfrequenz zwischen Mutter- und Tochtergesellschaft.

Das fünfte Kapitel zeigt anhand einer Fallstudie zur SAP AG, dass virtuelle Auslandsentsandte in Projekten der Abteilung SLO regelmäßig eingesetzt werden. Bei der Zusammenarbeit mit Kunden in asiatischen Ländern werden die SAP-Mitarbeiter aus Deutschland von lokalen Mitarbeitern vor Ort unterstützt. Der direkte persönliche Kontakt der deutschen Mitarbeiter mit den Kunden ist auf wenige Treffen im Jahr reduziert.

Die Fallstudie zeigt jedoch auch, dass der Koordinationsaufwand bei der virtuellen Zusammenarbeit steigt, da eine genauere Absprache der Verantwortlichkeiten und Aufgabenübergabe erfolgen muss. Zudem ergeben sich Probleme aus der mediierten Kommunikation. Allerdings kann eine starke Unternehmungskultur (wie bei SAP) dazu beitragen, diese Schwierigkeiten zu reduzieren.

Eine wichtige Grundvoraussetzung, so die Erkenntnisse aus der Fallstudie, ist die Garantie der Datensicherheit im Rahmen von virtuellen Auslandsentsendungen. Der Kunde muss zu jeder Zeit darauf vertrauen können, dass nur die autorisierten Mitarbeiter Zugriff auf die Daten haben. Darüber hinaus sind in der virtuellen Zusammenarbeit zwei Punkte für den Kunden von Bedeutung. Der erste Punkt bezieht sich auf die Beobachtbarkeit der Leistungserbringung. Für den Kunden ist es wichtig zu erkennen, was der Mitarbeiter macht bzw. welche Aufgaben schon erledigt sind. Diese Transparenz ist wichtig, da der Kunde die bezahlte Leistung auch im Prozess wahrnehmen möchte. Der zweite Punkt betrifft den Kontakt bzw. die Kommunikation zwischen Kunde und Projektteam. So wird von Kundenseite ein Hauptansprechpartner gefordert, der für alle Fragen des Projektes zur Verfügung steht.

Bei SAP wird der virtuelle Einsatz positiv von den Mitarbeitern aufgenommen, was in einer gesteigerten Arbeitszufriedenheit sichtbar wird. So bewerten die Gesprächspartner vor allem die abwechslungsreichen Aufgaben- und Einsatzgebiete sowie die flexible Arbeitsweise als positiv. Allerdings sehen die Befragten im Rahmen der Personalentwicklung noch Verbesserungspotenzial. So findet momentan ausschließlich ein Training on-the-job - gemäß dem prinzip ,learning by doing“" - statt. 
Abschließend verdeutlicht die Fallstudie von SAP auch, dass eine Bearbeitung von komplexen Projekten zwar durch virtuelle Entsandte sinnvoll unterstützt werden kann, der ausschließliche Einsatz virtueller Entsandter zur Projektabwicklung, zumindest bei Kunden und Projekten in Japan, jedoch noch nicht möglich ist.

Im sechsten Kapitel werden die Probleme virtueller Auslandsentsendungen erstmals systematisch untersucht. Die Befragung von 59 aktuellen oder ehemaligen virtuellen Entsandten zeigt, dass die Herausforderungen in vier Problembereiche eingeteilen werden können. Diese sind die Bereiche Kommunikation, Unterschiede im Zeitverständnis, Aufbau von Vertrauen und Führung auf Distanz.

Insbesondere die spezifischen Aspekte der interkulturellen und medial vermittelten Kommunikation stellen große Herausforderungen dar. Hierbei besteht größte Schwierigkeit darin, dass die genutzten Kommunikationsmedien eine relativ geringe Media Richness besitzen. Hierdurch lassen sich die Details der non-verbalen, extra-verbalen und para-verbalen Kommunikation schwer vermitteln, was die Gefahr von Missverständnissen erhöht. Einen zweiten Problembereich bilden Unterschiede im Zeitverständnis, die sich sowohl auf die wahrgenommene Verbindlichkeit von Terminen und Deadlines als auch auf den Zeithorizont der Entscheidungen auswirken können. Ein ebenfalls häufig genanntes Problem ist der erschwerte Aufbau von Vertrauen zwischen dem virtuellen Entsandten und seinen Interaktionspartnern im Gastland. Die fehlende face-to-face-Kommunikation erschwert informelle Gespräche und das persönliche Kennenlernen. Besonders relevant ist dieses Problem in Kulturen wie China oder Russland, in denen Berufs- und Privatleben in einem geringeren Maße differenziert sind, als dies in Deutschland der Fall ist (vgl. Holtbrügge \& Puck, 2005, S. 22 ff.). Schließlich stellt die Führung auf Distanz eine große Herausforderung virtueller Auslandsentsendungen dar. Da die Präsenz der im Heimatland tätigen Führungskraft nur medial vermittelt werden kann, stehen virtuellen Entsandten nur wenige Instrumente der Personalführung zur Verfügung. Insbesondere die Möglichkeiten der symbolischen Führung sind stark eingeschränkt. Das Mentoring sowie die Kontrolle und Motivation von Mitarbeitern werden dadurch erheblich erschwert.

Kapitel sieben verdeutlicht zunächst nochmals die interkulturelle Problematik beim Einsatz von virtuellen Auslandsentsendungen. Zentrales Ergebnis ist hier, dass Trainings für virtuelle Auslandsentsandte besonders wichtig sind, da diese nicht in der Lage sind, durch eigene Beobachtungen und Erfahrungen vor Ort von der fremden Kultur zu lernen. Die Anforderungen an Trainingsinhalte und -methoden sowie die Teilnehmer werden aus einer Fallstudie abgeleitet. Besonders bedeutend sind Trainingsinhalte, die sich auf das direkte Arbeitsumfeld beziehen. Ebenso hat spezifisches interkulturelles Wissen im Umgang mit elektronischer Kommunikation eine hohe Relevanz. Bei der Trainingsmethodik sollte auf eine didaktische Wissensvermittlung zurückgegriffen werden, die optimalerweise in einem virtuellen Klassenraum vermittelt wird, da dies ein Lernen unabhängig von Raum und Zeit und im Kontext der zukünftigen Arbeitsaufgabe ermöglicht. Des Weiteren entfaltet ein interkulturelles Training dann seine Wirkung am 
Besten, wenn möglichst viele Beteiligten der virtuellen Entsendung, also nicht nur der Entsandte, sondern ebenso seine Interaktionspartner, am Training teilnehmen.

Die Studie zeigt aber auch, dass selbst in Unternehmungen mit einem häufigen Einsatz von virtuellen Entsandten eine Vorbereitung auf den Auslandseinsatz nicht üblich oder standardisiert ist.

\subsection{Implikationen für die Forschung}

Aus den verschiedenen Kapiteln der Arbeit lassen sich zahlreiche Implikationen für die zukünftige Forschung ableiten.

Aus Kapitel zwei lässt sich zunächst grundlegend ableiten, dass virtuelle Entsandte bislang kaum Gegenstand wissenschaftlicher Forschung waren. Obwohl mit dieser Arbeit eine erste fundierte Analyse verschiedener Aspekte stattgefunden hat, bestehen weiterhin zahlreiche Lücken, die durch zukünftige Forschungen geschlossen werden sollten.

Die Ergebnisse der empirischen Studien aus Kapitel drei und vier zeigen, dass der Einsatz virtueller Entsandter zum Transfer von Wissen oder zur Kontrolle von Tochtergesellschaften anhand des Knowledge-based View bzw. der Transaktionskosten Theorie erklärt werden kann. Dabei werden jedoch nicht alle aufgestellten Hypothesen durch die Daten bestätigt. Im Rahmen des Knowledge-based View bleibt insbesondere ungeklärt, weshalb virtuelle Entsandte nicht zur Intensivierung des Wissensflusses von der Tochter- zur Muttergesellschaft beitragen. Zukünftige Studien könnten zur Erklärung dieses Ergebnisses beitragen, indem sie die Auswirkungen auf den Wissenstransfer unter Berücksichtigung von Kontingenzfaktoren, etwa verschiedener Internationalisierungsstrategien der Muttergesellschaft oder unterschiedlicher Investitionsmotive, die diese Beziehung beeinflussen könnten, prüfen. Auch in der Studie auf Basis der Transaktionskosten Theorie konnte der prognostizierte Einfluss einer Variable, der internen und externen Unsicherheit, nicht bestätigt werden. Auch hier könnten zukünftige Studien, etwa unter Rückgriff auf qualitative Untersuchungsmethoden, einen Beitrag zur Erklärung leisten. Darüber hinaus weisen beide Studien jeweils nur einen relativ geringen Erklärungsgehalt für den Einsatz virtueller Entsandter auf. Als Implikation für weitere Forschungen lässt sich daraus ableiten, dass zukünftigen Studien ein integrierter Ansatz, der verschiedene theoretische Modelle verknüpft, u.U. einen stärkeren Erklärungsansatz bieten könnte.

Im fünften Kapitel wird der Einsatz virtueller Entsandter in einer Fallstudie exemplarisch analysiert. Zwar lassen sich aus der Fallstudie zahlreiche relevante Ergebnisse ableiten, zukünftige Studien sollten aber insbesondere die Übertragbarkeit dieser Ergebnisse in andere Branchen testen. Dies gilt insbesondere für den Einsatz virtueller Entsandter in eher traditionellen Branchen. Zwar leistet das sechste Kapitel hierzu einen direkten Beitrag, trotzdem bleiben Fragen offen. 
Eine Implikation des sechsten Kapitels für die zukünftige Forschung besteht somit insbesondere darin, die herausgearbeiteten Problemfelder für unterschiedliche Anwendungsbereiche, Branchen und Unternehmungstypen zu spezifizieren. So kann etwa vermutet werden, dass die skizzierten Probleme bei kreativen Aufgaben größer sind als bei Routinetätigkeiten. Auch ein starker Einfluss der kulturellen Distanz zwischen Heimat- und Gastland kann vermutet werden. Zukünftige Studien sollten diese Ergebnisse nutzen, um eine detaillierte Analyse von Einflussfaktoren auf die abgeleiteten Problemfelder durchzuführen.

Im siebten Kapitel wurden die Grundlagen für ein kulturelles Training für virtuelle Entsandte entwickelt. Es kann angenommen werden, dass sich die Teilnahme an einem solchen, an den spezifischen Anforderungen virtueller Auslandsentsendungen orientierten, interkulturellen Training positiv auf die Effizienz und Zufriedenheit virtueller Entsandter auswirkt (vgl. Holtbrügge \& Schillo, 2008). In zukünftigen Studien sollte daher eine Evaluation eines solchen Trainings erfolgen. Darüber hinaus gilt es, weitere Instrumente und Maßnahmen zu erforschen, die der Bewältigung der Problemfelder virtueller Auslandsentsendungen dienen.

\subsection{Implikationen für die Unternehmungspraxis}

Neben diesen wissenschaftlichen Implikationen lassen sich auch zahlreiche Implikationen für die Unternehmungspraxis ableiten. Aus Kapitel zwei wird deutlich, dass virtuelle Entsandte grundsätzlich eine Alternative zu traditionellen Entsendungskonzepten darstellen können. Unternehmungen sollten prüfen, ob und welche Positionen zukünftig nicht mehr traditionell, sondern virtuell besetzt werden können.

Die in Kapitel drei vorgestellte Studie zum Einsatz virtueller Entsandter aus Perspektive des Knowledge-based View kann hierzu eine erste Entscheidungshilfe für Unternehmungen bieten. So hat sich gezeigt, dass virtuelle Auslandsentsandte besonders für den Transfer von kodifiziertem und standardisiertem Wissen mittels elektronischer Medien geeignet sind. Für Unternehmungen, die überwiegend auf diesem Weg und in dieser Form Wissen transferieren, stellen virtuelle Entsandte daher eine besonders attraktive Alternative zu traditionellen Entsendungen dar. Die Studie macht jedoch auch deutlich, dass der Einsatz virtueller Entsandter in Kulturen mit high-context-Kommunikation problematisch ist. Unternehmungen sollten virtuelle Entsandte hier nur sehr zurückhaltend und niemals ausschließlich einsetzen.

Auch die Studie in Kapitel vier leistet eine Entscheidungshilfe zum Einsatz virtueller Entsandter. So zeigt die Studie, dass Unternehmungen virtuelle Entsandte als Kontrollinstrument insbesondere in Tochtergesellschaften mit hoher Faktorspezifizität und häufig wiederkehrenden Transaktionen zwischen Mutter- und Tochtergesellschaft nutzen. Unternehmungen sollten gerade bei Existenz dieser beiden Voraussetzungen die Einsatzmöglichkeiten virtueller Entsandter als Kontrollinstrument intensiv prüfen, da diese u.U. eine kostengünstige Alternative zu traditionellen Kontrollmechanismen bieten können. 
Aus der Fallstudie in Kapitel fünf wird deutlich, dass sogar in Branchen mit generell hohem Anteil an elektronischer Kommunikation selbst bei standardisierten Projekte stets einen persönlichen Betreuungsanteil benötigen und nicht ausschließlich über virtuelle Entsandte abgewickelt werden können. Neben virtuellen Entsendungen sollten bei diesen Projekten daher immer auch traditionelle Entsendungsformen eingesetzt werden. Es wird jedoch auch deutlich, dass große Teile der Projektarbeit von virtuellen Entsandten durchgeführt werden können.

Der praktische Nutzen des sechsten Kapitels für die Unternehmungspraxis besteht in der empirischen Analyse der Problemfelder virtueller Auslandsentsendungen. Dadurch erhalten Unternehmungen, die virtuelle Entsandte einsetzen wollen, konkrete Ansatzpunkte, welche Herausforderungen mit der Entsendung verbunden sind. So können gezielt Maßnahmen, wie z.B. Kommunikationsschulungen und interkulturelle Trainings, ergriffen werden, um diese zu bewältigen. Aus den dargestellten Problemfeldern können zudem Anforderungskriterien für die Auswahl virtueller Auslandsentsandter abgeleitet werden.

Eine besonders starke Implikation für die Praxis ergibt sich aus Kapitel sieben. Es wird deutlich, dass der Erfolg einer virtuellen Entsendung durch die Teilnahme an einem interkulturellen Training erheblich gesteigert werden kann. Das Kapitel gibt konkrete Ansatzpunkte für die Gestaltung eines solchen Trainings. Unternehmungen können diese Vorgaben an die Spezifika ihrer Entsendungen anpassen und mit zukünftigen virtuellen Entsandten durchführen. 